\title{
Administrative Co-management in Special Use Forests of Vietnam
}

Nguyen Kim Dung 


\section{Thesis committee}

\section{Promotor}

Prof. Dr Arthur P.J. Mol

Professor of Environmental Policy

Wageningen University

\section{Co-promotor}

Prof. Dr Simon R. Bush

Professor of Environmental Policy

Wageningen University

\section{Other members}

Prof. Dr Esther Turnhout, Wageningen University

Prof. Dr Gerard A. Persoon, Leiden University

Prof. Dr Han W.M. van Dijk, Wageningen University

Dr John G.G.M. Kleinen, University of Amsterdam

This research was conducted under the auspices of the Wageningen School of Social Sciences (WASS). 


\title{
Administrative Co-management in Special Use Forests of Vietnam
}

\author{
Nguyen Kim Dung
}

\section{Thesis}

submitted in fulfilment of the requirements for the degree of doctor at Wageningen University

by authority of the Rector Magnificus

Prof. Dr A.P.J. Mol,

in the presence of the

Thesis Committee appointed by the Academic Board to be defended in public

on Wednesday 1 February 2017

at 1:30 p.m. in the Aula. 


\section{Nguyen Kim Dung}

Administrative Co-management in Special Use Forests of Vietnam,

195 pages.

PhD thesis, Wageningen University, Wageningen, NL (2017)

With references, with summary in English

ISBN: 978-94-6257-986-6

DOI: http://dx.doi.org/10.18174/393827 


\section{ACKNOWLEDGEMENTS}

My first acknowledgement of financial support is attributed to the Vietnam Ministry of Education and Training for awarding this $\mathrm{PhD}$ scholarship. Secondly, I would like to express my deepest appreciation to my promoter and co-promoter for their valuable contributions to my education. To Prof. Arthur Mol, I am grateful for making my $\mathrm{PhD}$ possible and providing me with valuable insights and guidance during the course of my study. To Prof. Simon Bush, I am thankful for his key role in instructing and contributing to this $\mathrm{PhD}$ thesis. Thanks to his critical thinking and challenging questions my knowledge has expanded 'step-by-step'.

My sincere thanks also go to all the staff of the Environmental Policy Group, Wageningen University, who supported me in different ways. Thanks goes to them all for their kindness and hospitality they provided me during the time I was at ENP. My particular thanks go to Corry Rothuizen for her readiness to support with administrative arrangements. I also would like to thank Prof. Jan van Tatenhove for his discussions in the course on Multi-level Governance which opened my eyes to the notion of 'policy paradox'. I would also like to thank Prof. Kris van Koppen for the support he gave me during the first drafts of my $\mathrm{PhD}$ proposal, and Astrid Hendriksen for checking the questionnaire, as well as her friendly talks and dinners. Thanks goes to Prof. Gert Spaargaren and Prof. Peter Oosterveer for providing me with insights into social theory, and Dr. Bettina Bluemling for organising a nice trip to visit her beautiful country. All the good moments I have had with you are stored in my heart for life.

I also would like to extend my thanks to all my friends in the Netherlands who made me feel home when I was away from home. It's impossible to name you all here, but you all touched my heart with your friendships and helpfulness. My special thanks go to Lenny Putman for giving me unforgettable memories in my first days in the Netherlands. My first Dutch Christmas was wonderful because of her lovely family, delicious food and a fantastic trip to the forest. My particular thanks also goes to Dorien de Jonge, who shared her house with me and was such a good friend during good and bad times. I thank Marjanneke Vijge for being a wonderful $\mathrm{PhD}$ fellow. I also very much enjoyed the company of Kanang Kantamaturapoj, Leah Ombis, Laurent Glin, Kim Ching, Dries Hegger, Gabor Szanto, Judith van Leeuwen, Elizabeth Sargant, Carolina Maciel, Natapol Thongplew, Joeri Naus, Jennifer Lenhart, Eira Bieleveldt-Carballo Cardenas, Khun Ying Nupueng, and Aggie Yeeting. Aggie Yeeting, I regret that I couldn't meet you sooner at ENP - it would have allowed us to spend more than only two months together. I also especially value my 
Vietnamese friends who was like my family away from home: Lan Huong, Chanh Tin, Dung Peter, Chi Xuan Huong, Co Chu Minh, Anh Ke - Chi Quyen, Em Trang - Thang, Em My Duyen, Chi Thu Ha, Chi Hoa, Chi Phung Ha, Thien Tam, Em Loan, Em Mai Huong, Em Cuc, Em Ai, Em My An, gia dinh Em Phuong Nam, Chi Loan. They made my life abroad so much easier and unforgettable.

The study would have not been possible without the cooperation from many managers of special-use forests, NGOs, and local people in Vietnam who had spent their time on my survey and submitted themselves to my interviews. I am deeply touched by the support they provided me. Many thanks also go to Dr. Luu Hong Truong for facilitating my interviews with the many managers. I also would like to express my gratitude to my respectful teachers and colleagues in HCMC University of Science, Vietnam: Prof. Le Cong Kiet, Dr. Tran Triet, Thay Duong Tien Dung, Dr. Phung Thuy Phuong, and Dr. Nguyen Phi Nga. From them I always received invaluable knowledge, inspiration, encouragement and support.

Last but not least, my deepest gratitude goes to my beloved family. My words for them must be in Vietnamese:

"Ba Má, con vẫn nhớ hoài có lần con nói con học $\mathrm{PhD}$ vì $\mathrm{Ba}$ Má và đã làm $\mathrm{Ba}$ Má thật buồn. Ba Má nói con nên nhận thức rằng con học vì con và vì Ba Má biết nó tốt cho tương lai của con. Trong nhiều năm trời vất vả làm $\mathrm{PhD}$, cuộc sống của con đôi khi rất xáo trộn nhưng nghĩ đến sự hỗ trợ hết mình của Ba Má, sự kỳ vọng của Ba Má đối với con nên con vẫn tiếp tục đi tiếp con đường chông gai mà con đã chọn. Nhìn lại những gì đã đi qua, con nghĩ $\mathrm{PhD}$ của con một nửa là dành cho $\mathrm{Ba}$ Má, một nửa là dành cho con với những tri thức con tiếp thu được sẽ giúp con mạnh mẽ hơn trong cuộc sống này. Con cám ơn những hy sinh của $\mathrm{Ba}$ Má, và biết ơn $\mathrm{Ba}$ Má vì cả hai đã luôn luôn cố gắng hết mình và làm tất cả để con cái có một cuộc sống tươi đẹp hơn. Con cũng sẽ cố gắng dùng cách $\mathrm{Ba}$ Má đã dạy con để dạy con của con. Con dành tặng $\mathrm{PhD}$ này cho Ba Má!

Con gái Phương Minh của Mẹ. Mẹ thật xin lỗi Con vì những ngày tháng Con phải xa Mẹ. Trong lòng Mẹ luôn kỳ vọng hoàn cảnh sẽ làm Con trở nên mạnh mẽ, độc lập, và bản lĩnh hơn so với các bạn cùng trang lứa. Và thật sự Mẹ thấy Con là một cô bé như vậy. Con sống rất hòa đồng và thông cảm với mọi người, bên trong sự nhu mì và lặng lẽ, Con là một cô bé rất bản lĩnh, thông minh và cá tính. $\mathrm{PhD}$ này Mẹ cũng dành tặng cho Con và mong Con khi trưởng thành sẽ sống độc lập trên đôi chân mình, luôn làm giàu tri thức cho bản thân mình. Con hãy nhớ nhé tri thức sẽ giúp Con trở thành một Con người mạnh mẽ, giúp Con biết đối phó tốt với những khó khăn xảy ra trong cuộc sống của Con, cũng như biết sống tốt trong mọi hoàn cảnh. Con hãy biến những ước mơ của riêng Con thành hiện thực nhé. Mẹ yêu Con nhiều lắm! 
Em cám ơn Chị của em Phương Ngọc, em của chị Bình - Thái đã luôn hỗ trợ và động viên hết mình cho việc học này. Nhìn lại những khó khăn đã đi qua mới hiểu hết sự thiêng liêng của hai tiếng "gia đình" phải không mọi người. Các cháu Lê Triết, Lê Uyên, Thái Bảo và Phương An hãy bay cao và bay xa với những ước mơ của mình nhưng hãy luôn nhớ cội nguồn, gốc rễ "gia đình" của mình nhé. Yêu thương mọi người rất nhiều". 


\section{TABLE OF CONTENTS}

TABLES X xii

FIGURES - xii

LIST OF ABBREVIATIONS xiii

Chapter 1

INTRODUCTION

1. Special use forests in Vietnam 1

2. Problems with SUF nature conservation 5

2.1 People in or people out?

2.2 Caught between forests and land $\quad 7$

2.3 Institutional fragmentation and weak capacity 8

3. Emergence of collaborative SUF management 11

4. Theoretical perspectives of co-management 13

5. Research objectives 15

$\begin{array}{ll}\text { 6. Methodology } & 17\end{array}$

6.1 A cross-national survey 17

$\begin{array}{ll}6.2 \text { Case study research } & 18\end{array}$

6.3 Other substantive data collection 19

7. Thesis outline $\quad 20$

Chapter 2

THE VIETNAMESE LEGAL AND POLICY FRAMEWORK FOR SPECIAL-USE FOREST CO-MANAGEMENT

1. Introduction 21

2. Policy related variables for analyzing co-management 22

3. Methodology 25

4. The legal basis of the national SUF system 26

5. Policy review of co-management 29

viii 
5.1 Pluralism and legitimate participation

5.2 Communication and Negotiation $\quad 32$

5.3 Transactive decision-making $\quad 34$

5.4 Social learning $\quad 35$

5.5 Shared actions and commitments $\quad 37$

6. Discussion $\quad 39$

7. Conclusion 41

Chapter 3

ADMINISTRATIVE CO-MANAGEMENT: THE CASE OF SPECIAL-USE FOREST
CONSERVATION IN VIETNAM

1. Introduction 43

2. The special-use forest system in Vietnam 45

3. Co-management research framework for Vietnam $\quad 47$

4. Methods 49

5. Results from the survey

5.1 The Pluralism of Vietnamese protected areas 53

5.2 Communication and Negotiation $\quad 55$

5.3 Transactive Decision-making $\quad 56$

5.4 Social-learning $\quad 56$

5.5 Shared Actions or Commitments

6. Discussion $\quad 59$

7. Conclusion: administrative co-management $\quad 61$

Chapter 4

THE VIETNAMESE STATE AND ADMINISTRATIVE CO-MANAGEMENT OF NATURE RESERVES

$\begin{array}{ll}\text { 1. Introduction } & 63\end{array}$

2. A critical Institutional Perspective of Co-Management 64 
4. SUFs Administrative Co-Management Arrangements 68

4.1 Emergence of Co-Management in Vietnam 68

4.2 Vertical Collaboration $\quad 69$

4.3 Horizontal Collaboration 71

5. Four Cases of Administrative Co-Management Arrangements 74

5.1. Cu Lao Cham Landscape Protected Area 74

5.2. Khau Ca Species and Habitat Reserve 75

5.3. Nui Chua National Park 76

5.4. Xuan Thuy National Park 77

6. Comparative Analysis and Discussion $\quad 79$

7. Conclusions $\quad 83$

Chapter 5

NGOS AS BRIDGING ORGANIZATIONS IN MANAGING NATURE PROTECTION IN VIETNAM

1. Introduction $\quad 85$

2. Bridging organizations in natural resource co-management 87

3. Methodology $\quad 90$

4. NGOs in Vietnamese administrative co-management arrangement of SUFs $\quad 92$

5. NGOs as bridging organizations: four case studies 94

5.1 Fauna \& Flora International (FFI) - International NGO 94

5.2 Vietnam National Park and Protected Area Association (VNPPA) -

Vietnamese Civic Association 100

5.3 Centre for Marine life Conservation and Community Development (MCD) Internationally funded Vietnamese local NGO 101

5.4 People and Nature Reconciliation (PanNature) - independent locally funded

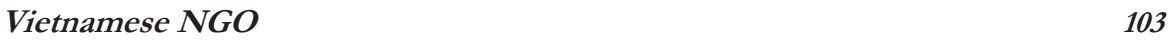

$\begin{array}{ll}\text { 6. Discussion } & 104\end{array}$

$\begin{array}{ll}\text { 7. Conclusion } & 108\end{array}$ 
Chapter 6

\section{DISCUSSION AND CONCLUSION}

$\begin{array}{ll}\text { 1. Introduction } & 109\end{array}$

2. Key dimensions of Vietnamese co-management 112

2.1 Moving beyond an 'instructive mode' of SUF co-management 112

2.2 Administrative co-management as a brand of Vietnamese SUF comanagement 115

2.3 Towards a networked vision of co-management 116

2.4 Creating space for NGOs as bridging actors 118

3. Conditions for overcoming 'administrative co-management' 120

3.1 Pluralism 121

3.2 Accountability 122

3.3 Incentives for administrative co-management 124

4. Co-management in 'mono-organizational' states 126

5. Recommendations $\quad 129$

$\begin{array}{ll}\text { REFERENCES } & 130\end{array}$

$\begin{array}{ll}\text { APPENDICES } & 155\end{array}$

$\begin{array}{ll}\text { SUMMARY } & 177\end{array}$ 


\section{TABLES}

Table 1.1. Current Category and Number of Special Use Forests in Vietnam 4

Table 1.2. Known, assessed and threatened species in Vietnam $\quad 4$

Table 1.3 Distribution of state authorities involved in special use forest management in 2008

Table 1.4. Case study visits

Table 2.1. Outline of questions asked across all document categories in systematic review

Table 3.1. Co-management matrix framework for investigating SUFs of Vietnam

Table 3.2 Levels of co-management in SUFs of Vietnam, according to dimensions and categories of special-use forests

Table 3.3 Percentages of special-use forests (SUFs) having collaborations with different actors

Table 4.1. Current and priority for future horizontal collaboration of SUF management boards

Table 4.2. Comparing administrative co-management in four case studies.

Table 5.1. Summary of survey questions

Table 5.2. Comparison of bridging abilities of four selected NGOs working in Vietnamese Special Use Forests

\section{FIGURES}

Figure 1.1. System of Special-Use Forsets in Vietnam

Figure 1.2 Vietnamese state organizations responsible for biodiversity and nature conservation

Figure 3.1 A comparison of Pluralism between four categories of SUFs

Figure 3.2. Percentage of SUFs that experience evaluation of policy applicability to their site

Figure 3.3. Percentage of SUFs that recognize the rights of local people to benefit from the areas

xii 
Figure 3.4 Collaboration between SUF management boards and local people

Figure 3.5. Average scores of co-management arrangements along five dimensions

Figure 4.1. Priority of SUF management boards in furthering governmental cooperation $\mathbf{7 0}$

Figure 4.2. SUF management board in administrative co-management networks. 73

Figure 5.1. Roles of NGOs as bridging organizations in natural resource management

Figure 6.1. Relational framework for reforming administrative co-management in centralised mono-organisational states

\section{LIST OF ABBREVIATIONS}

$\begin{array}{ll}\text { ASEAN } & \text { Association of Southeast Asian Nations } \\ \text { CBD } & \text { Convention on Biological Diversity } \\ \text { COMINGO } & \text { Committee for Foreign Non-Governmental Organization Affairs } \\ \text { CPC } & \text { Commune People Committees } \\ \text { DARD } & \text { Provincial Departments of Agriculture and Rural Development } \\ \text { DOF } & \text { Department of Finance } \\ \text { DOPI } & \text { Provincial Department of Planning and Investment } \\ \text { DOST } & \text { Provincial Department of Culture, Sports, and Tourism } \\ \text { DPC } & \text { District People's Committees } \\ \text { FAO } & \text { Food and Agriculture of the United Nations } \\ \text { FFI } & \text { Fauna \& Flora International } \\ \text { FIPI } & \text { Forest Inventory and Planning Institute } \\ \text { GDP } & \text { Gross Domestic Product } \\ \text { GEF } & \text { Global Environment Fund } \\ \text { GIZ } & \text { German Corporation for International Cooperation }\end{array}$


MARD Ministry of Agricultural and Rural Development

MARD Ministry of Agriculture and Rural Development

MB Management Board

MCD Centre for Marine life Conservation and Community Development

MOCI Ministry of Culture and Information

MONRE Ministry of Natural Resources and Environment

PanNature People and Nature Reconciliation

PES Payment for Environmental Service schemes

PFPD Provincial Forest Protection Department

PPC Provincial People's Committees

SUF Special Use Forest

UNESCO United Nations Educational Scientific and Cultural Organization

USAID United States Agency for International Development

VCF Vietnam Conservation Fund

VFA Vietnam Forestry Administration

VFF Vietnam Fatherland Fronts

VNPPA Vietnam National Park and Protected Area Association

VUFO Vietnam Union of Friendship Organizations

VUSTA Vietnam Union of Scientific and Technological Associations

WWF World Wildlife Fund

xiv 


\section{Chapter 1 \\ INTRODUCTION}

\section{Special use forests in Vietnam}

The conservation of forests and the biodiversity they contain remains a key global environmental challenge. This challenge is all the more important in countries like Vietnam when millions of people still depend on these forests for their livelihoods - either directly by exploiting the resources they hold, or indirectly from the 'environmental' services they provide society (Sunderlin et al., 2005; Bishop and Pagiola, 2012). As more demands are placed on forests the need to ensure that effective means of conserving them are put in place. But this is made all the more complicated where people cannot be, and given their social importance, should not be 'fenced out' (Persha et al., 2011). It is also made more complex as the interest in the conserving forests extends well beyond a single community or even a single country. As both biodiversity and the carbon embedded in trees and soil are increasingly viewed as a global common good the demands for forest conservation become even more global in nature (Vijge, 2016). At the same time, forest land remains a sovereign resource, and decisions on use, access and conservation remain are ongoing negotiation between the state and those citizens located in and around these forests. It is this negotiation, in the context of multiple claims on how forests should be used and conserved, that thesis addresses.

In Southeast Asia, forests are a particularly contested, and their conservation negotiated to varying degrees of success (see for example Sodhi et al., 2010; Miettinin et al., 2011). The economic growth of the region has placed emphasis not only on efficient resource use but also on conservation. In centralised states like Vietnam, which has been ruled by a single party for the last four decades, the state remains the key conservation decision maker over some of the most ecologically important forests in the region. Located within the IndoBurma Biodiversity Hotspot (IBBH), Vietnam is ranked as the sixteenth most biodiversity rich country in the world. It hosts 110 Key Biodiversity Areas (Mittermeier et al., 2004), and 62 Important Bird Areas (Birdlife International, 2016). The country also claims two World Natural Heritage Sites, five Ramsar wetlands, eight United Nations Education, Scientific and Cultural Organization (UNESCO) Biosphere Reserves and two Association of Southeast Asian Nations (ASEAN) Heritage Parks. Underlying this list of conservation governance arrangements is the country's high level of species endemism. It is estimated that $10 \%$ of Vietnam's plants are endemic to the country (Pilgrim and Tu, 2007), while 
twelve known species of mammals, seven species of birds, 48 species of reptiles, 33 species of amphibians and 80 species of freshwater fish are endemic to Vietnam (USAID, 2013).

To protect its natural heritage and biodiversity, Vietnam has established a three tiered system of forest management. The first tier is a system of 'protection forests' which consists of forests classified for upstream watershed protection, anti-shifting sand forests and coastal wave-breaking forests. The second tier is labelled 'production forests' which contains forests set aside for timber production and forest products. And the third tier is 'special use forest' (SUFs) "the backbone of the national protected areas system" (PARC 2006), comprising terrestrial forests, and a number of wetland and marine areas (ICEM 2003, see Figure 1.1). Although starting with Cuc Phuong national park in 1962, the number of SUFs only started to increase from 1993, when Vietnam officially became a member of Convention on Biological Diversity (CBD) (Zingerli, 2005; Meyfroidt and Lambin, 2008a). Today, Vietnam has a total of 164 SUFs covering 2.2 million hectares, equivalent to $7.4 \%$ of the country's total land area and $4.9 \%$ of national territorial waters (USAID, 2013). In 2014 the government made a commitment to again increase the number of SUFs to 176, which would cover an additional 200,000 ha by 2020 (Government, 2014; PanNature et al., 2014). As shown in Table 1.1, the expansion of SUFs under one system captures a wide range of land uses and levels of conservation, with national parks supplemented with nature reserves, species and habitat reserves, landscape protected areas and experimental and scientific research areas (MONRE, 2011b; PanNature, 2011a). As outlined above, many of these have received international recognition. However, despite the establishment of the national SUF system being deemed a 'success' (PanNature et al., 2014), a key paradox appears to have emerged, which questions the effectiveness of these protected areas. Despite the huge increase of SUFs over the last 25 years biodiversity and forest density in Vietnam continues to decline.

The decline in biodiversity in Vietnamese SUFs has been subject to much scrutiny (To Xuan Phuc, 2009; UNDP \& Government of Vietnam \& GEF, 2010). According to the Ministry of Natural Resources and Environment (MONRE) (2011b), the listed number of threatened species (critically endangered, endangered or vulnerable) is 882 (418 fauna and 464 flora) in the 2007 Vietnam Red Book, which means an increase with 161 species compared to the list of the year 1992. Nine fauna and one flora species are considered as extinct in nature (Dicerorbynus sumatrensis, Bos sawveli, Tapirus indicus, Cynogale lowei, Procypris merus, Anguilla japonica, Cervus nippon, Crocodylus porosus, and orchid Paphiopedilum vietnamese) while many others are faced with extinction, such as the primates Rbinopithecus avunculus and Trachypithecus delacouri. However, it is also thought that the official figures do not provide an accurate enough picture of the challenges faced by Vietnam given the absence of data accross a range of species categories (see Table 1.2). At first glance, the decline of biodiversity does not match the fact that forest cover in Vietnam has increased faster than 
any other Southeast Asian country over the last two decades; from 9.36 million ha in 1990 to 14.8 million ha (47.6\% of the land area) by 2015 (FAO, 2016; Masuda et al., 2016). However, the overall increase has been largely attributable to the expansion of plantations of fast growing monocultures of rubber, acacia, eucalyptus and pine (Nambiar et al., 2015). As outlined by Millet et al. (2013, citing Do et al. 2004), "by 2010 ... 1 million ha of these plantations were set-up in special use and protection forests", which supports aspirations for increase forest cover "but is not a source of biodiversity restoration" (p. 380) (see also Meyfroidt and Lambin, 2008b). To promote, conserve and restore biodiversity, attention needs to be given to an adequate quality of habitat that allows increases in the size of endangered populations.

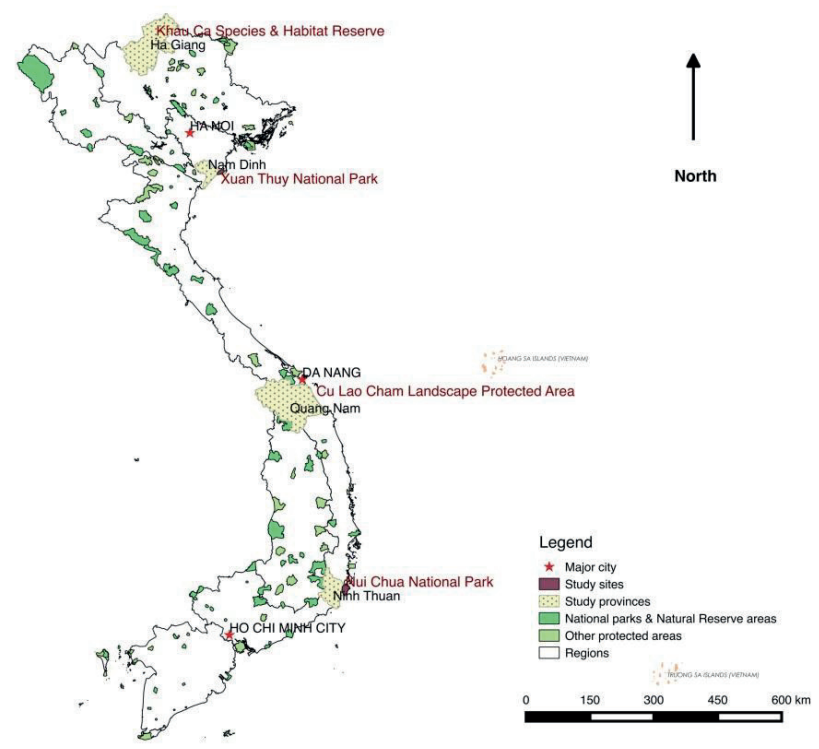

Figure 1.1. System of Special-Use Forsets in Vietnam (Source: Nguyen Hoai Bao, 2016) 
Table 1.1. Current Category and Number of Special Use Forests in Vietnam

\begin{tabular}{lcc}
\hline Category of Special-Use Forest in Vietnam & Total number & $\begin{array}{c}\text { Total area protected } \\
\text { (ha) }\end{array}$ \\
\hline National Parks (NPs) & 30 & $1,077,236$ \\
Natural Reserves (NRs) & 58 & $1,060,959$ \\
Species and Habitat Reserves (SHRs) & 11 & 38,777 \\
Landscape Protected Areas (LPAs) & 45 & 78,129 \\
Experimental and Scientific Research Areas & 20 & 10,653 \\
(ESRA) & & $\mathbf{1 6 4}$ \\
Total & & $\mathbf{2 , 2 6 5 , 7 5 4}$ \\
\hline
\end{tabular}

(Source: MONRE 2011b, USAID 2013)

A second major source of this decline is the ineffective management of SUFs, which is compounded by a combination of poor surveillance and weak active engagement with local communities surrounding SUFs who are dependent on forest resources for their livelihoods. Conflicts have commonly ensued between local users and authorities responsible for nature conservation when the former have been forcefully excluded from protected areas (Zingerli, 2005). Other evidence has pointed to the lack of alternative income opportunities for communities living around SUFs as a cause of continued levels of exploitation (Boissiere et al., 2009). In Vietnam, like many other

Table 1.2. Known, assessed and threatened species in Vietnam

\begin{tabular}{|c|c|c|c|c|c|c|c|c|c|}
\hline Group & 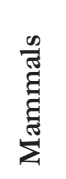 & $\stackrel{0}{0}$ & 总 & $\begin{array}{l}\frac{n}{\tilde{J}} \\
\frac{0}{0} \\
\frac{0}{0} \\
\frac{1}{2}\end{array}$ & 秀 & $\begin{array}{l}\frac{n}{0} \\
\stackrel{0}{0} \\
\overline{0} \\
\sum\end{array}$ & 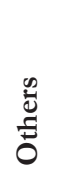 & $\frac{n}{\tilde{\Xi}}$ & $\begin{array}{c}\bar{\pi} \\
\stackrel{5}{H}\end{array}$ \\
\hline Known Species & 310 & 822 & 286 & 155 & 909 & $\mathrm{ND}^{*}$ & ND & 13700 & ND \\
\hline Assessed Species & 288 & 820 & 215 & 155 & 909 & 148 & ND & 718 & ND \\
\hline Threatened Species & 54 & 45 & 41 & 16 & 73 & 17 & 97 & 169 & 512 \\
\hline Endemics & 12 & 7 & 48 & 33 & $80^{* *}$ & ND & ND & ND & ND \\
\hline \multicolumn{10}{|l|}{ *ND- no reliable data } \\
\hline **Fresh water specio & & & & & & & & & \\
\hline
\end{tabular}

developing countries (Hayes, 2006), prohibiting natural resource use in protected areas provides no incentive for responsible and sustainable use; rather, local residents maximize resource exploitation as opportunities arise. The result has been the elevation of conflict between local communities and forest managers often because of the latter's efforts to exclude the former (McElwee, 2004; Zingerli, 2005; To et al., 2015). McElwee (2004) 
argued that extending the protected areas network is not feasible because of the limited number of rangers (Kiểm Lâm) to patrol larger areas and the historical animosity between the forest rangers and local populations. As elicited in one of her interviews with a ranger officer, SUFs can be considered "the forest of the three no's" (p. 130): no local people living close enough to protect it, no land given out to individuals to protect the forests on them, and no forest guards to check forest quality regularly.

If, following McElwee's ranger officer, the problem lies in the lack of 'people power' in forest conservation, then policies promoting more collaborative approaches appear to be necessary. Recognizing this, the Vietnamese government and international conservation organizations alike, have sought to develop what is referred to as collaborative or 'co'management (Plummer and FitzGibbon, 2004b; Plummer and FitzGibbon, 2006) in SUFs in an attempt to engage local stakeholders in protected area management and improve the protection of forest habitat and biodiversity (Boissière et al., 2009). Initially proposed in the 2003 Management Strategy for Protected Area System and the 2004 Land Law which set legal rights and responsibilities of local resource user involvement (Government of Vietnam, 2003), the basis of this turn to SUF co-management aims to reduce conflict over forest resources. This has translated into a variety of attempts to implement comanagement in SUFs across the country, by both the Ministry of Agriculture and Rural Development (MARD, 2005) and the Vietnam Conservation Fund (VCF), as well as through a number of foreign-funded pilot SUF co-management projects (Wyatt and Quan, 2007; Sandbrook et al., 2010b). However, despite nearly 15 years of implementing comanagement approaches in Vietnam, the extent to which it represents a transition from conventional government-monopolized conservation paradigm to an distinct comanagement system in Vietnam remains poorly understood.

\section{Problems with SUF nature conservation}

\subsection{People in or people out?}

From the establishment of the national SUF system until the present day the position of people in SUFs has remained contested. According to McElwee (2016), although based on an Arcadian view to nature conservation (based on the assumption of natural, pristine, human-less landscapes, see Worster, 1994) that gave rise to the national park system in the United States and other western countries, there are fundamental flaws to its realisation in regions like Southeast Asia. Following the Arcadian worldview initial plans for SUFs payed no attention to existing populations living in and around the forests and other terrestrial and marine biomes that were to be closed off for conservation. The assumption that these 
biomes were pristine, however, failed to address questions of how to properly manage degraded landscapes or landscapes that have been under human use for decades (McElwee, 2009). Contrary to nearly four decades of academic scholarship on state-led conservation in Southeast Asia (see for example Peluso, 1993; Sowerwine, 2004; Dressler et al., 2013), the establishment of SUFs in Vietnam has been based on a simple assumption that humans play no role in the ecology of forests in protected areas and that conservation means closing them off to maintain core ecological values.

According to McElwee (2016), what drives international biodiversity protection is an ecological paradigm that equates biodiversity with ecosystem stability and productivity, and the need for conservation of these functions. The universal model to set up a protected area for biological conservation seemed to include steps of: a) finding an area worthy of conservation (often for the conservation of flagship mammal or bird species, or for generalised biodiversity value); b) making a boundary around this area; and c) keeping people out as much as possible. This model is in some ways enshrined in IUCN international guidelines for park classification (see Dudley 2008) which, although followed by Vietnam, fits uncomfortably with the SUF system because all SUFs have people living in and around them (McElwee, 2016). Nevertheless, these generalised steps used to establish SUFs emphasise ecology over people. First, the government decides where a SUF should be located. Second, the biological boundaries and management principles of the SUF are defined. Third, local people in and around SUFs are consulted on how they will deal with the SUF boundaries. And last, anyone negatively affected by SUF boundaries will receive 'resource substitution' such as assistance with agro-forestry or non-wood forest product development. Despite the social exclusion that is inherent the establishment of these protected areas in Vietnam (see also To et al. 2012; Dressler et al., 2013). McElwee (2016) also notes that their effectiveness in conserving forest ecological is far from certain: many are small by international standards, too isolated, degraded or contained little value for biodiversity conservation, and there is some doubts about the values of SUFs in terms of being unique and endangered species and ecosystems.

Core to the conflicts surrounding SUFs are therefore a rigid set of policies and law enforcement which are seen as not supportive of local livelihoods (Sunderlin, 2006; To Xuan Phuc, 2009; McElwee, 2010; Sikor and Phuc, 2011). For marginalised indigenous people the impacts are even greater given the largely unfounded blame they receive for destroying nature through swidden agriculture and shifting cultivation has resulted in their removal from SUFs by governmental resettlement projects, often sponsored by foreign conservation organizations (McElwee, 2006). Despite being removed for the purpose of "wilderness" conservation, evidence shows that they are often quickly replaced by other groups such as hunters, poachers and immigrants, as well as business interests that have greater impacts than the people originally moved (ibid.). As McElwee (2006) argues, it is 
these 'frontier' settlers in combination with government supported cash crop development, illegal logging, in-migration projects, and corruption that are by far greater threats to SUFs than the people removed from the parks in the first place. The overall result, as asserted by To Xuan Phuc (2009), is that SUFs face a diverse set of social challenges and as a result have become contested space for groups of people with different interests and power.

\subsection{Caught between forests and land}

The politicisation of SUFs is also strongly linked to modes of land and forest management that the Vietnamese state implemented as part of wider economic reform in the 1990s. Despite land allocation programmes focused on shifting land to households (see Phuc and Sikor, 2008; Dressler et al., 2013), forest resources were largely transferred from State Forest Enterprises to the Forest Protection Department and the Forest Management Boards of SUFs (McElwee, 2004). At the same time, community forest management remained politically sensitive given the divide between the extremes of total state management of forests and individuals households management of other lands (Sunderlin, 2006). Just after the promulgation of the forestry law in 1991 (which is revised in 2004) McElwee (2004) suggested that one solution for this apparent impasse between forest and land institute land tenure regimes with a strong "social incentive" for forest management through a combination of community use rights and inter-household land tenure regimes such as co-management.

The early development of collaborative management in SUFs was hindered by the allocation of forest and land rights. In general the SUF system is biased towards forested, mountainous ecosystems where the large numbers of ethnic minorities in Vietnam live (Baulch et al., 2002; Sowerwine, 2004; Baulch, 2010). The state itself has admitted that most of the SUF have been allocated in remote or mountainous areas with difficult geographical conditions for socio-economic development (Nguyen Huy Dung and Dung, 2007; MONRE, 2011b). Even today groups living in and around SUFs have neither forest or forest land use rights. They are prohibited to $\log$, exploit, hunt animals, and collect specimens under any means and form, while they are extremely poor and marginalised (Sowerwine, 2004; To et al., 2013 Dressler et al., 2013). Despite calls by NGOs for the government to allocate rights and support these communities little has been done (see VNGO\&CC et al., 2013; VUFO-NGO Resource Center, 2013; McElwee, 2016) - in part because there is very little information on the conditions under which these people live.

Today SUFs have a complex mix of overlapping land use rights (Vietnam Forestry Administration, 2014). According to PanNature (2014), 49\% of SUFs are dealing with conflicts over the ambiguities that arise over access to both land and forest resources. Many of these conflicts have not been resolved from the time when the SUFs were established. 
While the government provides guidance on how to establish a SUF in 2010 (Decision $117 / 2010 /$ ND-CP), these guidelines have not made the allocation of forest and land any clearer. As a result overlapping land use rights remain a central issue. As argued by PanNature et al. (2014) this means that the implementation of forest protection and conservation management remains an exercise of exerting control over "the lands of others" (p. 13). The consequence for affected communities is that taking up a role in stateled conservation means acknowledging they have defaulted their rights to access and use forest resources. From the start of any SUF then it seems that relations between SUF managers, forest rangers and local communities are faced with conflicts between livelihood and conservation, and between statutory and customary laws (PanNature et al., 2014, p. 11). It therefore appears that any step towards collaborative management requires a shift away from the state centric model of conservation as control.

\subsection{Institutional fragmentation and weak capacity}

The wide range of environmental 'domains' represented by the national SUF system, ranging from forest management to conservation and rural development, means that their administration is divided over multiple government authorities. But as acknowledged by the Vietnamese government itself, the coordination between these authorities is plagued by overlapping legislation and a lack of clear division between institutional mandates for management by the various authorities involved (Development Partnerships, 2010; MONRE, 2011a; USAID, 2013)(see Figure 1.2 and Table 1.3). At the national level, the Vietnam Forestry Administration (VFA) within the Ministry of Agricultural and Rural Development (MARD), is primarily responsible for coordinating the national SUFs system, including the direct administration of six inter-provincial national parks (Vietnam Government, 2003; Development Partnerships, 2010). Where other habitats and resources involved, SUF management can also involve other branches of the government. For instance, wetlands are divided between the Ministry of Natural Resource and Environment (MONRE) and MARD (VEPA, 2005); (Vietnam Government, 2001). MARD remains the main authority responsible for marine protected areas (PARC Project, 2006). But if cultural or landscape protection is involved in a SUF, then the Ministry of Culture, Sports, and Tourism is also involved.

At the provincial level, the Provincial People's Committees (PPCs) are responsible for the administration of all other SUFs (McElwee, 2016). Based on the size and importance of forests, PPCs might assign district governments to manage and develop activities such as tourism (Vietnam Government, 2001). But the majority of Vietnam's SUFs are managed by Provincial Departments of Agriculture and Rural Development (DARDs), in collaboration with the provincial Forest Protection Department, and Department of Culture, Sports, and Tourism (DOCST) which fall directly under the control of the PPCs (Development Partnerships, 2010; Swan, 2010). SUFs that are small in size, and not managed by the 
District level Forest Protection Department, report directly to PPCs. At the operational level, SUF Management Boards are staffed by officials assigned by provincial DARDs and

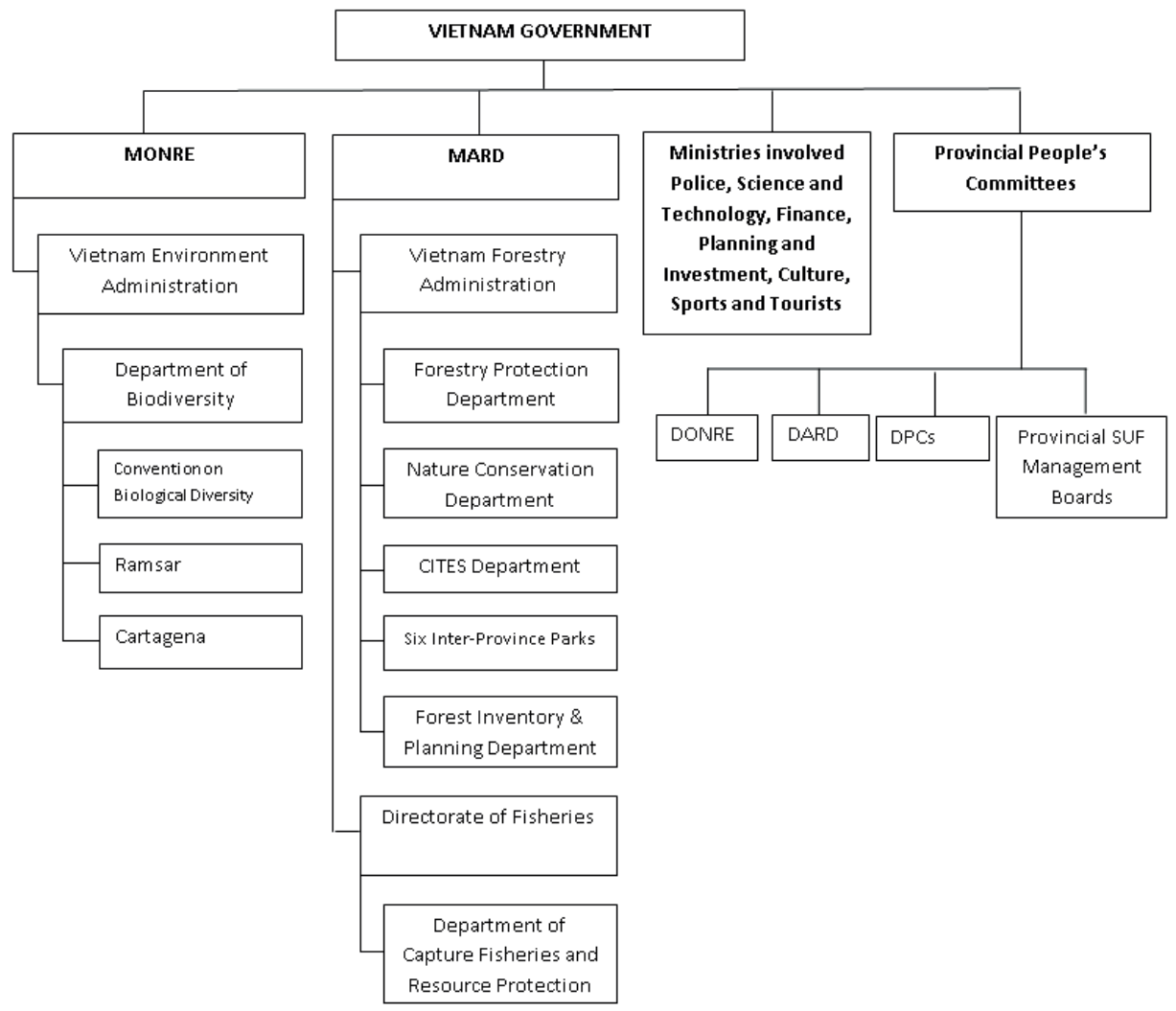

Figure 1.2 Vietnamese state organizations responsible for biodiversity and nature conservation (Source: Adapted from MONRE 2011a)

responsible for management and protection (ICEM, 2003). The board does not include representatives from other sectors or stakeholders (private, NGOs, or community). Wheremanagement boards have not been established (which severely hinders any form of local management, (MONRE, 2011a; McElwee, 2016), SUFs are under the management authority of either District Forest Protection Departments, Provincial DARDs, or DOCSTs (Government of Vietnam, 2003). Overall, SUF management is highly variable and dependent on a mix of interests and official designations coming from both the national and provincial level. 
Table. 1.3 Distribution of state authorities involved in special use forest management in 2008

\begin{tabular}{|c|c|}
\hline Organisations directly in charge of SUFs management & Number of SUFs \\
\hline Vietnam Forestry Administration & 6 \\
\hline Provincial People's Committees & 24 \\
\hline District People's Committees & 2 \\
\hline Provincial Forest Protection Department & 43 \\
\hline District Forest Protection Department & 4 \\
\hline DARD & 19 \\
\hline $\begin{array}{l}\text { Department of Culture and Information (today Culture, Sports and } \\
\text { Tourist) }\end{array}$ & 4 \\
\hline Department of Forestry Development & 1 \\
\hline State Forest Enterprises & 3 \\
\hline No/Unclear Management Organizations & 22 \\
\hline Total & 128 \\
\hline
\end{tabular}

(Source: Forest Protection Department 2008, cited in MONRE 2011b)

Day-to-day management by SUF management boards is also fragmented by the variety of state and non-state organisations supporting conservation activities. One major issue confronting managers is also the availability and skills of the staff at their disposal. Most SUF staff are faced with multiple concurrent tasks set by the PPCs. According to Decree 117/2010/ND-CP, SUFs larger than 15,000 hectare should have an established Forest Ranger Unit with enough capacity to cover 500 hectare per ranger (Article 28). However, this level of capacity is hardly ever reached (Development Partnerships, 2010). Expansion of the SUF system is instead limited by low salaries for rangers and limited personnel to patrol large areas.

It has also been demonstrated that the skill levels of SUF staff are limiting factors in dealing with the complex social dynamics surrounding historical animosity between the rangers and local populations (McElwee, 2004). For example, a recent assessment by GIZ (2012) found that in spite of 100 persons/day of training per SUF, overall levels of competence are very low and unevenly distributed, suggesting that training opportunities have been uneven across the SUFs. Furthermore, while competency levels were acceptable in the traditional skills associated with SUFs, such as monitoring and surveillance, they were very weak in fields important to biodiversity conservation, such as biodiversity assessment, SUF policy and planning, recreation and tourism, and community relations. SUFs and protection forests in Vietnam have to fulfill roles that go beyond conservation, including the delivery of environmental services and benefits to buffer zone communes. The result is that capacities go far beyond what is stipulated and available for managing what is in practice a highly diverse, fragmented and conflict ridden national system of conservation. 
The capacity of SUF managers is also limited by the lack of financial resources. Historically, SUFs have received substantial levels of support from international donors, which in recent years have started to withdraw leaving the government to bear the direct costs of management (Development Partnerships, 2010; McElwee, 2016). In 2010, governmental support for environmental protection in general was $0.4 \%$ of GDP, of which only about $10 \%$ went to nature conservation. This amounts to around USD $\$ 5$ million per park per year. However, about $90 \%$ of these budgets are invested into infrastructure such as roads and housing, with the rest amounting to an inadequate budget reserved for nature conservation activities (PARC Project, 2006; Development Partnerships, 2010). If managers wish to expand activities, into buffer zone activities, for example, there is no financial incentive mechanisms to do so. Management boards are dependent on the annual budgets assigned from the PPCs set in long and medium-term financial plans (PARC Project, 2004; Development Partnerships, 2010). This has drawn attention to new financial streams, such as Payment for Environmental Service schemes (PES), which are hoped in part to strengthen the capacity of SUFs, but in effect appears to only act as a means of reallocating money from one state actor to another (McElwee et al., 2014). Where international funds have been available, the activities supported have tended to focus on a strongly expansionist conservation agenda - evidenced by more than 71 additional SUFs proposed to the government by Western conservation agencies in the 2000s (Birdlife International 2001). As argued by McElwee (2016) in very few cases are people-forest relations put at the centre of the debate on how to better manage SUFs.

The consequences of this institutional fragmentation and weak capacity is that ambitions to address the social dimensions of SUF management, whether that be reactively resolving conflicts or proactively establishing long term relationships with affected communities, are limited. It is also telling that since 1990 there have been only a handful of attempts to develop participatory planning around SUFs, while there are no recorded cases in which the establishment of SUF is stopped because of objections by local people (McElwee, 2016). Despite this there is a clear ambition to develop more collaborative forms of SUF management that attempt to improve ongoing relations with affected communities.

\section{Emergence of collaborative SUF management}

In recognition of the many of the issues raised above, the Vietnamese government has attempted numerous times, and through a variety of programmes, to improve community collaboration in the national SUF system and improve the protection of forest habitat and biodiversity (Boissière et al., 2009). The 2003 Management Strategy for Protected Area System and the 2004 Land Law set legal rights and responsibilities of local resource user 
involvement, and the reformation of policy to strengthen state management and local authority capacities (Government of Vietnam, 2003). Since 2005, Vietnam Conservation Fund (VCF) has used funding from the Global Environment Fund, TFF and the European Union to support the development of co-management approaches in SUFs (MARD 2005). Furthermore, Vietnam has committed to the CBD Programme of Work on Protected Areas, which requires the establishment of policies and institutional mechanisms to support full participation of indigenous and local communities (IUCN 2006). To do so, Vietnam has piloted co-management approaches in many SUFs since 2001, and as of 2003 included co-management in its official national strategy for SUF management (Sandbrook et al., 2010a; Swan, 2010). In the Vietnam forestry development strategy for 2006-2020, the government states that community forest management would be scaled up and the government would provide all financial and policy supports to construct and pursue the approach across the sector. More recently, there are also many new policies with attempt to diversify financial sources for SUFs and mobilise participation of local people, such as supporting communities at SUF buffer zones with 40 million VND per village per year (Decision 24/2012/QĐ-TTg), Payment for Environmental Services PES (Decree 99/2010/NĐ-CP), and implementing models of co-managing SUFs and sharing benefits from resources of SUFs (Decision 126/2012/QĐ-TTg).

As asserted by the current MARD Vice-Minister Hua Duc Nhi, co-management has the potential to become a mainstream model for managing natural resources in Vietnam (IUCN, 2010). Others, such as the NGO PanNature (2015) have also noted that the current Vietnamese policies provide co-management with a promising means of solving overlapping land rights in many SUFs (Nguyen Hai Van and Nguyen Viet Dung, 2015) and offering a means of achieving greater compliance with SUF management regulations. However, it is also widely noted that co-management is a particularly great challenge in Vietnam because of the nature of strong state control, decades of SUF conflicts, and the lack of capacity and initiatives of communities to negotiate with the government (IUCN, 2010). Moreover, it is argued "policy reform [in Vietnam] is necessary but not sufficient; what is also needed is a change in policy and practice toward shared governance", which requires not only "the establishment, reaffirmation, or change of institutions to resolve conflicts over resources" but also "leadership from the highest levels of government" to make that such reforms really happen in "contemporary Vietnam" (IUCN, 2010; see also Lloyd, 2010).

The Vietnamese political system is markedly different from western countries, especially when it comes to the concept of 'ownership' of nature resources and the essence of democracy (Lai, 2008). This holds central challenges for the implementation of comanagement which is considered as a democratic, efficient and equitable system of governance (Helene, 2006). According to Lai (2008), "legally and politically, the Vietnamese 
Government is willing to provide an environment for democracy and support for democracy in all areas and sectors, but this might not be fully the same as the democracy defined by the western countries" (Lai, 2008, p. 4). Therefore, conditions of the economic, political and social context surrounding SUFs is key to any understanding of comanagement can be implemented, including insights into how co-management may need to amended to adjusted to 'fit' the context of mono-organisational states.

\section{Theoretical perspectives of co-management}

The conceptual basis of co-management stems from the early 1990s when a core group of scholars started to address the perceived mismatch between community and state led management of common pool resources (Berkes et al., 1991; Pomeroy, 1995a; McCay and Svein, 1996; Sen and Nielsen, 1996; McElwee, 2016). The concept has been widely used ever since in natural resource management literature, especially with respect to fisheries and forestry. Today, co-management is strongly related to the adaptive governance literature, where multiple actors at multiple levels continuously interact to solve problems and adjust their positions and activities to respond to changing circumstances (Carlsson and Berkes, 2005). Reflecting this wider scope, Plummer and FitzGibbon (2004b) argue that a broad definition of co-management is preferred, namely, the distribution of rights and responsibilities pertaining to a particular resource among governments and local users. At its core, co-management captures the idea that rights and responsibilities in natural resources management should be shared between government and any non-state actor (including resource users, local communities, environmental NGOs or scientists) (Plummer, 2009). As Plummer et al. (2013) argue, co-management is advocated not only because it holds potentials to enhance the effectiveness of natural resource protection and management, but also because it brings stakeholder participation and therefore fairness, transparency, legitimacy and accountability to management.

The focus on stakeholder participation is derived largely in opposition to the perceived failure of centralised (state) management and the aspiration for alternative modes of management that result in the sharing of responsibilities and authority (Arthur, 2005). It is widely asserted that co-management offers meaningful participation in management by those who are subject to regulations, by allowing joint decision making that takes into account the needs of resource users, and in doing so considers the complexities and uncertainties they face (Carlsson and Berkes, 2005; Armitage et al., 2009; Bown et al., 2013). Faced with the perceived failure of government-led management co-management is also thought to improve compliance to jointly defined regulation, provide more locally relevant management plans, and in regions such as Southeast Asia, even reduce poverty through 
diversifying economic activities (Pomeroy, 1995b; McBeath and Rosenberg, 2006). If these wider goals can be achieved co-management is thought to also offer a means of conflict resolution (Noble, 2000). Additionally, Pomeroy and Berkes (2004) argue that comanagement helps reduce costs of resource management such as data collection, monitoring and enforcement, and leads to the empowerment and self-determination of local communities (see also Rodon, 1998; Shackleton et al., 2002; Plummer and FitzGibbon, 2004a; Nicol, 2014).

Questions of co-management also emerge over the degree to which it can be put in place and the degree of 'adaptiveness' it can engender. This means that we are able to move beyond co-management as a normative hope and start to unpack co-management as a set of fragile, contested decisions and partnerships between highly diverse actors (Armitage et al., 2009; Trimble and Berkes, 2015; Crowe et al., 2016). What is also clear is that a great deal of the literature on co-management has been focused on evidence from Western liberal democracies where deliberation and the sharing of authority are part of much wider trajectories 'from government to governance' (Armitage et al., 2009; Trimble and Berkes, 2015; Crowe et al., 2016). In these countries the sharing of decision making and authority have led to a range of wider debates about the ongoing role of the state in cases where nonstate actors have taken over traditional state functions, including the management and control of national parks and conservation (Olsson et al., 2007; Berkes, 2009; Plummer and Fennell, 2009; Butler et al., 2015; Davidson and Loë, 2016). At the other end of the spectrum lies what is referred to as 'mono-organisational' states (see Rigby, 1982), where decision making and executive functions of government are centralised to a very high extent. It is to this latter category of states that Vietnam belongs and where this thesis focuses its attention on by questioning the possibilities for adaptive forms of collaborative management in the national SUF system.

The notion of a 'spectrum' of co-management, with more or less state/non-state decision making power and authority over natural resources offers an analytical entry point to the debates over co-management (Pomeroy and Rivera-Guieb, 2006; USAID's Coral Triangle Support Partnership, 2013; Finkbeiner and Basurto, 2015). It also offers the possibility to move beyond binary notions of state-community forms of co-management and opens up to multi-polar or networked forms of co-management with varying interactions among the state, communities, NGOs and other public interests, as well as companies and private interests (Carlsson and Berkes, 2005; Finkbeiner and Basurto, 2015). Reflecting on this Finkbeiner and Barsuto (2015) recently called for moving beyond traditional conceptualizations of co-management to "multi-level co-management" in order to explicitly emphasize the principles of power devolution based on subsidiarity, cooperative partnerships, democratic participatory involvement, and polycentric and governance networks. Analytically, these multi-level or multi-polar co-management arrangements open 
up questions on the role and function of multiple interdependent public and private actors at different levels and scales, who cooperate in practical real-life arrangements and partnerships to solve problems of such a resource management (Adger et al., 2005; Carlsson and Berkes, 2005; Berkes, 2010; Marín and Berkes, 2010).

Throughout this thesis I will return to the theoretical basis of adaptive and networked forms of co-management as ideal types to question the extent to which protected area management in Vietnam can establish more collaborative forms of management. In doing so the thesis explores not one, but two so called 'spectrums'. First, the spectrum focuses on adaptiveness possible under the conditions of mono-organisational states. The second spectrum centres on the degree to which non-state involvement is politically feasible in the context of these states. By taking these two theoretically informed spectrums the thesis explores the wider relevance of co-management to centralised states. As such this thesis contributes calls in the co-management literature for knowledge on the shift from a static concept of management to a more dynamic concept of co-management governance in multi-levels and -scales (Berkes, 2009) and the important role of institutions and institutional processes in conferring adaptiveness by creating conditions for its evolution (Berkes, 2009; Armitage et al., 2011; Ratner et al., 2012). The focus on mono-organisational states and on domains of forest nature conservation protected areas, is an especially major contribution as these areas remain poorly covered in the literature worldwide.

\section{Research objectives}

Given the empirical and theoretical challenges outlined above this thesis will examine how the current form of co-management national system of Special Use Forests governance of Vietnam can be characterised, and how and to what extent more adaptive form of SUF comanagement to evolve in Vietnam's forest management. To respond to these questions, four sub-questions will be addressed, each of which corresponds to the four empirical chapters.

First, which form of co-management is supported, and to what extent, by the current policy and legal framework in Vietnam? Despite the establishment of a legal basis for SUF comanagement, and more than 10 years of experience in introducing concepts of community participation into SUFs, there remains the question to what extent co-management has really been implemented and operationalized in legal and policy documents. And which form of co-management is actually supported? To understand what changes are needed and can be implemented, this first question enables a clear identification of whether the central government provides a clear vision and strategy for introducing different degrees of co- 
management. In investigating policies and laws on stimulating and facilitating SUF comanagement this paper contributes to a wider understanding of how Vietnam includes (which) ideas of co-management in its still predominantly state-organized system of nature protection.

Second, how and to what extent has the actual governance of Vietnam's SUFs shifted from conventional government-based management to co-management? Despite the ongoing conflicts associated with illegal use of SUF resources a shift from the conventional government-monopolized conservation paradigm to an alternative co-management system appears to be underway in Vietnam. However, the extent to which co-management has been institutionalized across the country is unknown, with most information derived from a relatively small number of case studies. While there is considerable research on comanagement in Vietnam, most of the studies completed are based on one or a few sites. This second question aims to provide a national overview of co-management across the country and in doing so provide a classification of the current status and form of comanagement in Vietnam and contribute to a better understanding of the ongoing changes to Vietnamese nature protection.

Third, what influence do vertical and horizontal linkages within the multiple levels of the state Vietnam government influence the form and function of SUF co-management? Moving beyond a national level analysis, this question assesses the co-management network dynamics surrounding SUF management boards and their capacity to fulfil their mandate and collaborate with local communities. Based on in depth case-study research this question explores the role and influence of vertically related state agencies connect to the management boards of Special-Use Forests and horizontal networks of non-state actors in the development of collaborative SUF management. In doing so the chapter extends the existing co-management literature in Vietnam and beyond, to focus on the internal dynamics of state interaction, the effect on community cooperation, and the impact on natural resource management.

Fourth, in what way might NGOs fulfil "bridging organisation" roles in Vietnamese SUF co-management arrangements? This question focuses on the extent to which NGOs can assist the state to overcome the constraints faced in implementing co-management in the national SUF system. In doing so this chapter contributes to debates on the role of NGOs as a non-state actor in countries where conservation continues to be a policy goal of the central state, but by the same token NGOs remain constrained by a lack of space for independent political advocacy and policy intervention. This paper feeds directly into the wider aim to determine the level of 'adaptiveness' that can be developed in co-management given the political constraints inherent to a mono-organisational state such as Vietnam. 


\section{Methodology}

To address these questions a two-level methodology was adopted throughout this thesis. The first level focuses on the national level with the goal of identifying patterns and characteristics of SUF co-management across the country. The second level focuses on contrasting case studies, designed to draw out diverse local contexts and conditions while allowing for comparison (Yin, 2013). These levels are restricted to separate papers, but instead implemented throughout the thesis, allowing me to cross-check general and specific findings against each other. In both levels of analysis quantitative and qualitative forms of data collection and analysis were employed. Further details on methodology and associated methods are given in each of the four empirical papers. Here I provide a general introduction to the common elements of the two-level methodological approach taken across these four studies.

\subsection{A cross-national survey}

To explore patterns of co-management arrangement in Vietnamese SUFs I first conducted a cross-national survey of managers directly responsible for management in the 143 SUFs across the country (following a draft version of the 2010 SUF list of the Forest Protection Department, excluding the 20 experimental research forests). The cross-national survey was designed to identify generalizations about SUFs by finding the prevalence of situations, problems, attitudes and issues across a wide sample (Kumar, 2005). As such the survey helps to answer "what" questions (Yin, 2013), including what is a general current SUF comanagement arrangement in Vietnam and what are strategic interactions of SUF managers with state actors (multi-level government, state enterprise, police, border guards) and nonstate actors (civil society organisations, private enterprises, university and research institutes, and local people). Importantly, it also helps to quantify the extent to which the Vietnamese SUF management have moved away from the centralised conservation management towards co-management, in accordance to the spectrum of theoretical comanagement arrangement.

To collect data a mix of a structured questionnaire was combined with follow-up in-depth interviews with SUF managers to clarify and validate the responses in returned questionnaires. The questionnaire (Appendix 1) was constructed and structured with a total of 37 questions with an aim to explore facts and opinions of 143 SUF managers towards SUF operations including administration, types and degrees of cooperation with state and non-state actors, and perceptions toward roles of different actors positioning in the SUF co-management arrangement. By moving between the interviews and survey responses a descriptive picture of co-management was built up that allowed for cross-validation of results (Yin, 2013). The goal of this cross-validation was to move between the specific and 
general data in order to increase the confidence of the interpretations of the information collected.

\subsection{Case study research}

The second level of analysis was based on a case study approach. By moving to this level of analysis the goal was to investigate a contemporary phenomenon within its real-life context (Yin, 2013). By examining how strategic interactions of actors in SUF co-management arrangements in contrasting contexts took place (Yin, 2013), these case studies provided thick descriptions from which interpretations and generalizations could be drawn, as well as cases could be cross-checked with each other (Shenton, 2004). Following Flyberg (2006), these case studies were designed to seek out 'typicalities' between and commonalities across the cases. By moving between these typical and common elements interpretations were made systematically, and in a way that allowed for tentative generalisations to reached.

Case selection for chapters 4 and 5 were based on different criteria, each relevant to the case study approach taken. The four cases selected in chapter four were selected on the basis that they represented a 'most different' sample of SUFs (Seawright and Gerring, 2008) based on the results of the cross-nation survey, which indicated major differences in the (diversity of) involved actors and in the perceptions of on-site SUF managers regarding their successfulness of co-management. By selecting the cases in this fashion, I was able to diagnose how the different co-management institutional arrangements perform (comparatively) when confronted with similarly environmental challenges. In chapter 5 , the cases were selected again on the basis of 'most different' criteria. However, this time the cases were not selected on the basis of the national survey, but by selecting exemplary representations (Yin, 2013) of different types of NGOs operating in SUFs which are explicitly engaged in co-management.

Data are collected through semi-structured interviews through face-to-face communication with state actors such as representatives of Forestry Protection Department (MARD) (date 26/10/2009, in Hanoi) and representatives of Provincial People's Committees (PPCs), District People's Committees (DPCs), Commune People Committees (CPCs), DARD, DONRE, forest rangers, border guards, and non-state actors such as non-government organisations (NGOs), and local resource users for each case. The case visits were executed as reported in Table 1.3 by a research team of $4-5$ people, which comprised of myself as research leader and a few assistants (local guide, university colleagues, and graduate students trained by me). Most of the interviews took between 1-2.5 hours and were recorded and transcribed. The interviewees were asked about roles, responsibilities, interests, and perceptions of the different actors involved in SUF management, the advantages and disadvantages of involving them, and the interaction with each other in real co- 
management arrangements (Appendix 2, 3, and 4). These information was coded in accordance with requirements for answering research questions in chapter 3, 4 and 5.

Table 1.4. Case study visits

\begin{tabular}{|c|c|c|}
\hline Case study & Visit 1 & Visit 2 \\
\hline 1. Nui Chua National Park & $19-21 / 10 / 2009$ & $10-15 / 01 / 2011$ \\
\hline 2. Xuan Thuy National Park & $27 / 10 / 2009$ & $2-6 / 03 / 2011$ \\
\hline $\begin{array}{l}\text { 3. Khau Ca Species and Habitat } \\
\text { Reserve }\end{array}$ & $7-11 / 03 / 2011$ & \\
\hline $\begin{array}{l}\text { 4. } \mathrm{Cu} \text { Lao Cham Landscape } \\
\text { Protected Area }\end{array}$ & $15-20 / 03 / 2011$ & \\
\hline 5. NGO-MCD & $\begin{array}{l}\text { 20/10/2009 visited MCD } \\
\text { office in Khánh Hòa province } \\
\text { and Ran Trao coral reef - an } \\
\text { MCD project site }\end{array}$ & $\begin{array}{c}26 / 10 / 2009 \text { (Hanoi } \\
\text { office) }\end{array}$ \\
\hline 6. NGO-VNPPA & $28 / 02 / 2011$ & \\
\hline 7. NGO-FFI & $1 / 3 / 2011$ & \\
\hline 8. NGO-PanNature & $14 / 3 / 2011$ & \\
\hline
\end{tabular}

\subsection{Other substantive data collection}

To consolidate the quality of the research, additional observations and discussions were also conducted during workshops and conferences. Two national workshops on SUF management held in Hoa Binh province (May 2013) and Ho Chi Minh City (September 2013) were significant research sites because they focused on the interactions of different state actors and non-state actors, especially NGOs on the development co-management in SUFs. By observing and recording these exchanges further context was provided to the survey and case studies outlined above (Ritchie et al., 2013). They also provided a further guide on setting up additional analysis of secondary sources that were either discussed or referred to during these meetings, such as legal and policy documents and reports. All these sources helped to review policy on SUF co-management arrangements, documents and practices of state and non-state actors, perspectives of a diversity of stakeholders toward Vietnamese SUF management. 


\section{Thesis outline}

The thesis comprises of six chapters in which four chapters (2 to 4$)$ are written in the format of scientific articles, while this chapter sets the introduction of the research and chapter 6 provides a general discussion of the findings of the research undertaken.

The first empirical chapter (Chapter 2) raises vital concerns about the legal framework for officially enabling SUF co-management to exist and evolve in the Vietnamese socialpolitical-economic context. Relevant national policies and legal documents are reviewed, within a framework of SUF co-management in Vietnam. Chapter 3 reports empirical data from the cross-national survey of the SUF managers against a spectrum of co-management arrangements developed from the theories. This helps understand what a Vietnamese SUF co-management arrangement looks like and assess to what extent the government has actually shifted the SUF management toward "international practices" of co-management. Chapter 4 moves to investigate the existing or "Vietnamese way" of SUF co-management through examining actor interactions in vertical and horizontal linkages of the arrangement through the lens of network governance perspectives. Chapter 5 then discusses the challenges faced by NGOs to fulfil the role of "bridging organisations" within the SUF governance system. Finally, the last chapter draws out the research findings and figures out how the findings feed into the theoretical perspectives of co-management. 


\section{Chapter 2}

\section{THE VIETNAMESE LEGAL AND POLICY FRAMEWORK FOR SPECIAL-USE FOREST CO-MANAGEMENT}

\section{Introduction}

Special-use forests are considered an important part of the nature conservation strategy of the Vietnamese government, ensuring the protection of terrestrial forests, wetlands and marine areas for a period of 50 years (ICEM 2003). Currently, the total of about 2.2 million hectares are covered by 164 SUFs made up of 30 national parks, 58 nature reserves, 10 species and habitat reserves, 46 landscape areas and 20 scientific research forests (MONRE, 2011b; PanNature, 2011a).

Vietnam forest policy covers a wide range of issues from forest management, protection and enrichment, to private investment, research, and human resource development. In the case of SUFs, increased attention has also been given recently to promoting community participation through new policies and laws. It is estimated that $80 \%$ of SUFs are inhabited, either by communities who had historical claims on land or by those who have encroached on buffer areas (Cuong, Dung et al., 2009) . Ongoing conflicts and unrest between SUF managers and these communities has often ensued when households were forced to remove from protected areas, or when their livelihood opportunities became restricted (Zingerli, 2005; Boissière, Sheil et al., 2009). Over the last two decades attention has been given to 'land-titles', 'benefit sharing' and 'rights for forest owners' in more than 100 forestry related legal documents, at national, provincial and local levels (Sam and Trung, 2001; Tan, Chinh et al., 2008). However, given the long history of centralised control of forestry resources in Vietnam, stretching back to the French colonial period (Adger, 1999), policies and legislation relating to community involvement in SUF management, protection and development remains under-developed (Boissiere, Sheil et al., 2009).

The Vietnamese government does recognize the role that communities living in and around SUFs can play in the protection of SUF resources through collaboration or 'co'management as an alternative to centralized state control of forest resources (Pomeroy, Nguyen et al., 2009; IUCN, 2010). As argued by the Vice-Minister of the Ministry of Agriculture and Rural Development in 2010, co-management has a great potential to become a mainstream model for managing natural resources in Vietnam (IUCN, 2010). A legal basis for co-management in SUFs has also been established in 2003 through the Strategy for Managing the System of National Parks and Natural Reserves of Vietnam to 2010 (Decision 192/2003/QĐ-TTg 2003) and the Prime Ministerial approval of Vietnam 
Forestry Development Strategy for 2006-2020 (Decision 18/2007/QĐ-TTg 2007). The Strategy (2007) is most explicit in its support for co-management, stating that community forest management needs to be tested and upscaled with funds provided for SUF management boards from the central government to support the forest protection groups as well as "forest protection and development".

Despite the establishment of a legal basis for SUF co-management, and more than 10 years of experience in introducing concepts of community participation into SUFs, there remains the question to what extent co-management has really been implemented and operationalized in legal and policy documents. Do governmental policies from the national to the district level facilitate co-management and what kind/form of co-management is developed? In investigating policies and laws on stimulating and facilitating SUF comanagement this paper contributes to a wider understanding of how Vietnam includes ideas of co-management in it still predominantly state-organized system of nature protection.

The following section provides an outline of current thinking around co-management and identifies five criteria against which I structure the review of Vietnamese policy. I then explain the methodology adopted for the review before presenting the results. The final two sections of the paper discuss and conclude on the results of the review, explaining the extent to which co-management is supported in current Vietnamese policy and law and identifying future opportunities for overcoming the major bottlenecks for co-management in the SUF system.

\section{Policy related variables for analyzing co-management}

Co-management relates to various forms of partnership between public and private actors that defines a degree of shared responsibility for functions and entitlements related to the management of natural resources (Carlsson and Berkes, 2005; Ratner, Oh et al., 2012). There is no one model or blue-print for co-management, instead academic scholarship has focused on the degree to which co-management arrangements can create adaptive responses from the parties involved to deal with different rates of environmental and social change (Folke, Carpenter et al., 2002; Armitage, Plummer et al., 2008; Plummer, 2013). But while considerable attention has been given to institutional design of co-management arrangements few studies have undertaken in depth investigations of the degree to which state policy and legislation enable or constrain the emergence and type of co-management. Even less attention has been given to the specific challenges that centralized 'monoorganizational' socialist states such as Vietnam (Thayer, 1995) face in transitioning to a collaborative mode of natural resources. 
From an critical institutional perspective co-management is more than just a statecommunity relationship between the state and homogenous community structures (Finkbeiner and Basurto 2015). Instead co-management can be understood as a series of partnerships, shared decision-making processes and devolved authority for key functions such as monitoring and enforcement (Arthur, 2005; Borrini-Feyerabend, Farvar et al., 2007). Seen as such, co-management is moving away from singular vertical partnerships between government and resource users to encompass multi-level networks of interactions among the state, communities, NGOs and other public interests, as well as companies and private interests (Carlsson and Berkes, 2005; Finkbeiner and Basurto, 2015). The assumption is often that these networked forms of co-management are more able to foster adaptive decision making. But specifically, what kinds of policies and laws support more adaptive forms of co-management remains under-researched (Macfadyen, Cacaud et al., 2005). We expand on these questions by reviewing the national legal and policy framework for SUF co-management development in Vietnam.

To address the complexity of co-management Plummer and FitzGibbon (2004a) identify five characteristics of co-management that enable an investigation of the diversity of interests and inputs, operationalization of power and a process of learning to adjust and adapt. These are pluralism, communication and negotiation, social-learning, transactive decision-making and shared actions and/or commitments.

Pluralism relates to the inclusion of various interests and/or inputs in the process of comanagement. As outlined by USAID (2013), governments can foster pluralism in policy and legislation, simultaneously across multiple levels, and either mandated or made voluntarily. For example, national level government can develop legislation to authorize and legitimize the rights of resource users to organise and enforce co-management arrangement. Legislation can also be put in place that shapes decentralised management, recognises community based management systems and provides assistance through incentives and determining allocation of management functions. Provincial and district level government in turn can establish policy and legislation for providing technical assistance, requiring accountability of co-management partners and dealing with abuses of local authority. Local government can play a more immediate role in policing local co-management partners to meet responsibilities, as well as support community involvement and mandating enforcement by local regulators.

Communication and negotiation are seen as key functions of co-management that can be enabled through information exchange and feedback to gain consensus and common understanding amongst stakeholders (Plummer and FitzGibbon, 2004a). Here, policy and legislation can be used by government to set clear requirements for establishing a shared understanding around relevant issues and the creation of a shared vision through 
deliberative processes (Berkes, 2010). Finkbeiner and Basurto (2015) claim that establishing responsibility for these deliberative processes across multiple levels can assist in voicing divergent perceptions, needs, and goals both between actors at the same level (e.g. resource users) and/or between resource users and the state. It is also expected that legislation and policy around communication and negotiation can be set at any of the levels outlined above.

Social learning refers to on-going knowledge creation by sharing values, jointly implementing actions and reflecting upon feedback (Plummer and FitzGibbon, 2004a; Pahl-Wostl, Sendzimir et al., 2007). Social learning occurs when actors involved learn to incorporate knowledge generated from a given experience into new collective practices of resource management (Pinkerton, 1994; Finkbeiner and Basurto, 2015). Government can facilitate social learning by either suggesting or mandating that experiences with comanagement be reflected on and fed back into new projects, thereby enabling gradual improvement. Government can also shape more flexible legal frameworks for comanagement ensuring that any changes in policy and legislation be established in such a way that amendments are possible without placing too much of a procedural burden on those involved (Macfadyen, Cacaud et al., 2005). In this way, the process of social learning can be shaped by the state with input from those involved directly in co-management.

Transactive decision-making focuses on the process through which information from multiple types of knowledge contribute to more equitable and efficient co-management processes (Plummer and FitzGibbon, 2004a). Co-management can be a means of alleviating conflicting perspectives by setting stages for a deliberative process of regulatory decision making among user-groups and government agencies. It can also facilitate discussion around the inclusion of local customary practices, norms, and institutions into formal policy. Government policy can enable more or less transactive decision making through the extent to which participatory decision making is required in practice. The degree of transactive decision making also then plays a direct role in the determining the level of legitimacy of a given co-management arrangement (Jentoft, 2000). Similarly, legitimacy can also be influenced by the extent to which local custom, culture and the knowledge of resource-user groups are required in establishing co-management (Pomeroy, 1995; Jentoft 2000). Finally, as argued by Macfadyen et al. (2005) legislation can support more transactive decision making by protecting individuals against the abuse of local power.

Shared actions and/or commitments refer to the willingness of all actors to undertake joint activities under collaborative forms of management (Plummer and FitzGibbon, 2004a). There is often a strong need for incentives for stakeholders to participate in comanagement. In Vietnam, incentives for group cohesion have been found to be a mix of both financial costs and benefits, as well as a range of welfare and social functions (Macfadyen, Cacaud et al., 2005). Policy and legislation can encourage or mandate co- 
management arrangements to include such costs and benefit in such a way that commitment is created for direct support for management. For example, by mandating that fees are collected for local enforcement (Pomeroy, 1995). By balancing such costs with demonstrable benefits from enforcement and dispute resolution, or improved reference to measures for reducing poverty or vulnerability, greater commitment for participation can be fostered (Arthur, 2005). Likewise, mandating the provision of technical assistance and administrative, technical, and financial services is also noted as increasing the longevity of co-management institutions (Pomeroy and Berkes, 1997; Finkbeiner and Basurto, 2015).

In the rest of this chapter I use the above five characteristics of co-management to evaluate the extent to which Vietnamese policy and legislation provide an enabling environment for co-management in the national SUFs system.

\section{Methodology}

The review of publically available national-level legal documents, conducted in 2015, was based on the operationalization of the five co-management characteristics. The policy and legal documents included in the review do not explicitly indicate that they are regulating SUF co-management. However, by focusing on areas of policy and law that are relevant to forests and community participation we have been able to identify 51 documents (see Table 2.2 in Appendix 5) that contribute to the national legal framework of SUFs that have a direct influence on the five characteristics of co-management outlined above.

The search was based on four pre-determined categories of documents, each holding relevance to different characteristics of co-management (see Table 2.1). First, SUF strategy documents and action plans were reviewed. These documents were targeted because they hold information on the SUF development and processes of policy improvement related in particular to social learning. Secondly, operational documents of SUFs were reviewed which focus specifically on the designation of responsibilities and the authorities of different actors. Thirdly, policy documents related to public communication and reporting requirements and to civil society involvement were reviewed. These documents were particularly relevant for understanding policy and legislation related to communication, transactive and participative decision making, and social learning. Finally, administrative guidelines for forest management, civil society, village organisation and operation, and the Commune People Councils were reviewed. These documents revealed insights into transactive decision making, pluralism and commitment as steered by the institutional and political makeup of the Vietnamese government. 
The documents were systematically reviewed with information coded according to the five characteristics of co-management outlined above (see Table 2.1). For pluralism, I looked for information about which actors are responsible for SUF management, how are they positioned and legitimated in the SUF arrangement and how the notion of community was treated in the structure of SUF management. For communication and negotiation, I focused on information relating to the mechanism of exchanging information and feedback among stakeholders across scales and levels. For transactive decision making, I looked for information related to how multiples types of knowledge/actors were collected as well as contribute to the process of decision making. Related to this I also looked for evidence of who was legitimated by this knowledge to make decisions about the management of SUFs. For social learning I drew on information relating to legislation aimed at mandating or facilitating feedback from experiences with SUF management and the investment of this feedback into the design of new mechanisms, governmental interventions, and policy modifications. In order to understand shared actions and/or commitments, I searched for legal information relating to incentives (financial/political/welfare/social functions) for stakeholders to participate in SUF management, and how the cost and benefits from SUF management are shared.

\section{The legal basis of the national SUF system}

The national legal framework for SUFs is an assemblage of laws, ordinances, decrees, circulars, directives, and decisions to impart legal instruments (Tan et al., 2008). Like all other areas of law and policy, the National Assembly is the highest level legislature in the country. Below the Assembly is the executive central government who drafts laws, ordinances, and decrees. Executive branches such as Ministry of Agriculture and Rural Development (MARD), Ministry of Natural Resources and Environment (MONRE) and lower governmental levels (city, province) issue legal documents to guide and instruct the implementation of these laws, ordinances and decrees. 


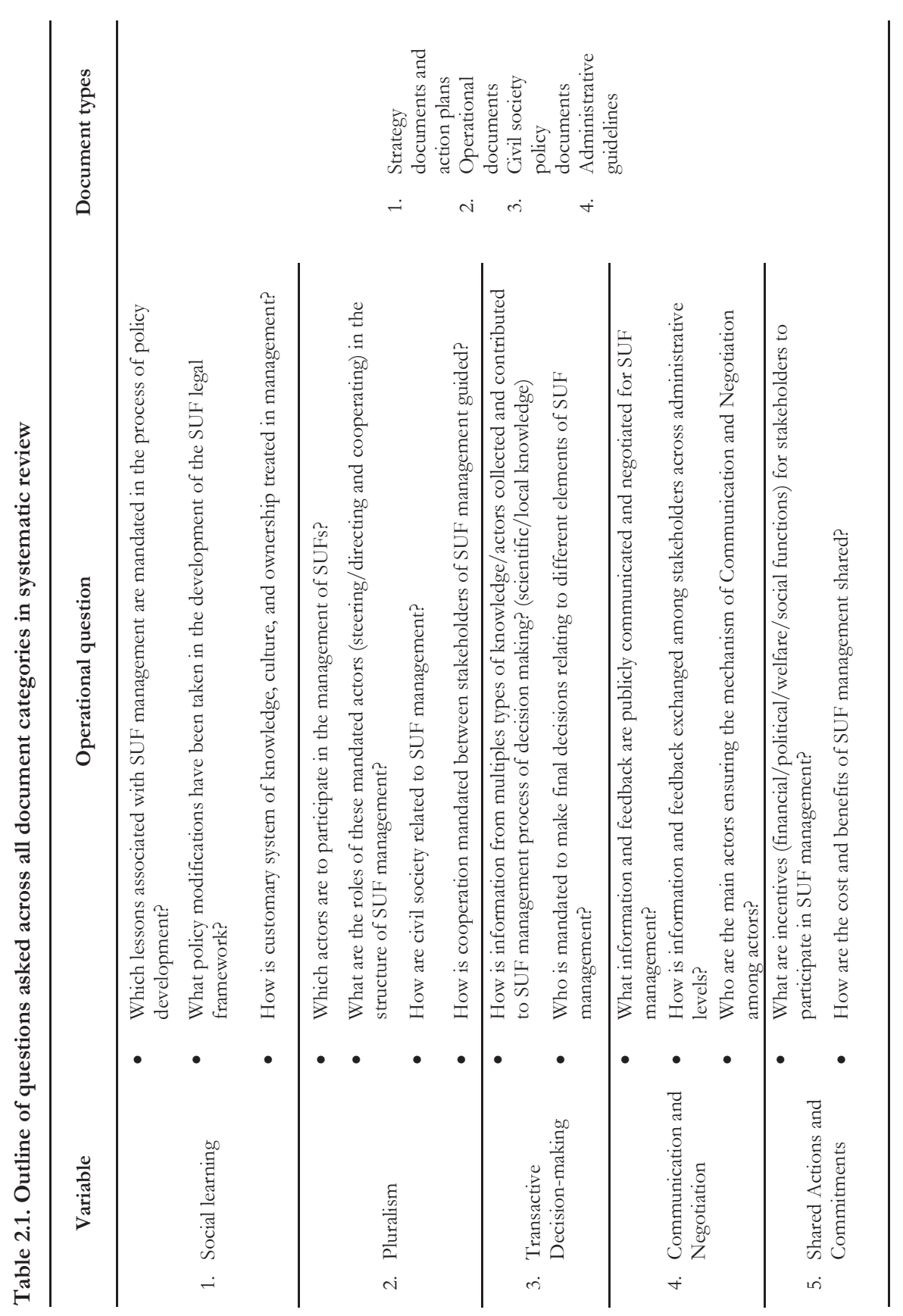

ง 
MARD and MONRE are responsible for the management of forest, forest resources, and forest lands. Under the administration of MONRE, the General Department of Land Administration is responsible for undertaking forest land management and enforcing the forest land law. Under the administration of MARD, the Vietnam Administration of Forestry and Forest Protection Department is responsible for consultation and legitimately enforcing forest and forest resource protection across the country, as well as concurrently managing six inter-provincial national parks, (Cuc Phuong, Tam Dao, Ba Vi, Yok Don, Cat Tien, and Bach Ma) (Decree 119/2006/ND-CP). MARD is regulated to play key roles in SUF management, having powers to be involved in most aspects of all SUF management, whether central or local, such as establishing, adjusting, guiding, examining and inventorying SUFs (Decree 117/2010/ND-CP).

The Vietnamese SUF system is classified as state property in keeping with wider national objectives of conserving and restoring forested land. Following the period of economic reform (Doi Moi) from 1986 to 2006, forests now represent a source of national benefit, bringing together economic welfare and conservation through the protection of natural ecosystems, genetic resources, historic and cultural landscapes, and other biological resources with the potential for scientific research (Decree 117/2010/ND-CP; Decision 1250/2013/QD-TTg; Decision 218/2014/QD-TTg). Protection and conservation are therefore closely related to economic strategies for national, sectoral, and local socioeconomic development as well as the national strategy for climate change mitigation (Decision 218/2014/QD-TTg).

The SUF system is regulated through a national master plan implemented by MARD and the Provincial People's Committees. At the national level the master plan is based directly on parallel master plans for national social-economic development, the national defense system, land use, and forest protection and development. At the provincial level SUF management is based on the national master plan, as well as the provincial social-economic development plans and the provincial defense system plan (Decree 117/2010/ND-CP).

Each SUF also has an individual operational plan made up of an initial status and planning report (Decree 117/2010/ND-CP). This report outlines the status of the forests, ecosystems, biodiversity, history, culture, landscapes, scientific aspects, environmental education and services. It also provides an inventory of the status of natural resource utilization and management, and an evaluation in local livelihoods in the surrounding area. These are then used to set objectives for the SUF, including a description of its boundaries, action programs, measurements for project implementation and management, and information related to investments and management costs. Changing SUF plans is only possible when changes are made to national or provincial planning for social-economic development or defense (Article 19 Law on Forest Protection and Development). To make 
these changes permissions are required from relevant authorities such as MARD, MONRE, and PPCs. (Decree 117/2010/ND-CP).

The basis of the SUF system is the restriction of resource exploitation which can adversely affect biodiversity, natural and cultural landscapes and scientific resources (Decree 117/2010/ND-CP). National parks, nature reserves and species/habitat conservation areas are divided into three exploitation zones. First, a strictly protected zone is identified, with the goal of ensuring natural succession of forests and ecosystems. Second, ecological restoration zones are installed, which focus on natural regeneration activities through the plantation of indigenous plants. And third, service-administrative sub-zones are classified, where silvi-cultural measures may be taken to improve the quality and aesthetic values of forests. For landscape protection areas, forestation, forest rehabilitation and other silvicultural measures may be taken under approved schemes, projects and designs.

SUFs are controlled by SUF management boards who are responsible for ensuring 'holistic forest management' (Law on Forest Protection and Development 2004). In cases where personnel for forest protection is lacking, SUF management boards are permitted to allocate forests to households and individuals for protection. Management boards are also permitted to engage with 'economic organisations', for instance related to ecotourism development investment. However, they are legally prohibited to transfer ownership (Law on Forest Protection and Development 2004) because they bear responsibility as the main legal authority over SUFs (Circular 18/2004/T'T-BTNMT; Decree 117/2010/ND-CP).

\section{Policy review of co-management}

We now turn to a review of the various policy and legal documents relevant for SUFs. The review is grouped into five sections, corresponding with the characteristics of comanagement outlined in section two of this chapter.

\subsection{Pluralism and legitimate participation}

In Vietnamese policy two groups of actors are defined in what relates to 'pluralist' policy processes: 1. State actors involved in decision making, and 2. Non-state 'cooperating' actors. There is an overall obligation under law for local people, including villages and hamlets, to participate in SUF management (Law on Forest Protection and Development 2004; Decree 117/2010/ND-CP; Decision 218/2014/QD-TTg). However, both policy and legislation involves central state agencies that take control of processes of pluralism, with governmental actors decentralizing responsibility for actor engagement to the local commune level. This leaves cooperating groups as those working at the SUF level under the 
coordination of these centralized state actors (Table. 2.2). The result for co-management is that policy both enables and constrains pluralism by limiting legitimation to state-centric control.

The People's Committees at provincial, district, and commune levels are responsible for forest and forestland management under the jurisdiction of their administrative authorities. Accordingly, professional organisations and officers in charge of these governmental levels are responsible for consulting local resource users and enforcing the forest law. DONRE, DARD, Provincial Forest Protection Department, and Environmental Protection Department are examples of those professional organisations. The Provincial Department of Forest Protection is an important agency because it is responsible for advising authorities on the protection of forest and for ensuring enforcement of forest protection and development at the local level. It also organizes and instructs commune level actors on forest protection, as well as disseminates regulations on forest protection and development. Finally, it is responsible for ensuring and reporting on compliance to the guidelines of the Central Department of Forest (Decree 119/2006/ND-CP).

At the local level, Community People's Committees (CPCs) are responsible for implementing laws and policies on forest management and protection across their jurisdictions (Article 38, Law on Forest Protection and Development 2004). Every CPC is required to establish and manage contracts for forest and forestland allocation to both households and companies (Decision 1174/QD-TTg and Decision 57/QD-TTg). They are also required to guide the implementation of forest protection and management plans, and direct villages, hamlets and relevant units to construct and carry out forest protection and development. It is also through the CPCs that the state engages with the public through forest rangers, police, and army for forest protection (Decision 1717/2006-QD-BNN-KL, Decision 147/2007/QD-TTg, and Decision 192/2003/QD-TTg). In addition, CPCs are in charge of monitoring ecotourism in SUFs (Decision 104/2007/QD-BNN) and also for managing the implementation of payments for ecosystem service programmes (Decree 99/2010/ND-CP).

Direct participation in SUFs is controlled by management boards who are tasked with coordinating a network of key actors including forest rangers, CPCs, forestry companies, other organizations, individuals, households, groups of households and communities at grassroot level (Law on Forest Protection and Development 2004; Decree 119/2006/NDCP; Decree 117/2010/ND-CP; Decision 218/2014/QD-T'Tg). Management boards are also responsible for organising the participation of communities in buffer zones for forest protection, conservation, 'wise utilization' of forest products, and environmental services with a view to enhancing local livelihoods (Decision 186/2006/QD-TTg). Furthermore, any community forest management is also coordinated through SUF management boards (Official Document 1327/CV-LNCD dated 7/9/2007 issued by MARD). 
The day-to-day management of SUFs remains state-centric. National parks and special-use forests that have areas of 15,000 ha or above can have their own forest ranger unit equivalent to the District Department of Forest Protection. But smaller SUFs rely on collaboration with commune and district level groups. In these SUFs, daily management activities are centralized through the commune forest ranger service, who are assigned to work with CPCs and District Department of Forest Protection (Decision 1717/2006-QDBNN-KL). Commune forest rangers also have legitimate roles in disseminating policies and laws to communities and villages (Decision 1717/2006-QD-BNN-KL). At the district level, the Forest Protection Department is responsible for cooperation and collaboration with government organizations, the army, and forest owners to implement forest protection in their administrative areas. At both commune and district level cooperation with communities is based on their relation with communities with training and guidance on planning forest protection and forest fire prevention, as well as information exchange and evaluation (Decree 119/2006/ND-CP; Decision 1717/2006-QD-BNN-KL and Decree 74/2010/ND-CP).

Community involvement in forest management is also centrally coordinated. The term "community" is defined in the 2005 Law on Forest Protection and Development as the households and individuals living in the same villages or hamlets (Article 3, Clause 3). Communities have the legal obligation to participate in constructing and implementing plans and methods of forest protection and management in direct collaboration with the local civil defense and forest rangers (Decree 74/2010/ND-CP). The law does however provide scope for the voluntary formation of cooperatives by farmers for the specific purpose of co-managing natural resources (Decree 151/2007/ND-CP). The government also demonstrates its commitment to promoting customary laws in forest management (Decision 192/2003/QD-TTg; Decision 1174/2005/QD-TTg; Decision 106/2006/QDBNN, Circular 70/2007/TT-BNN) and has specifically indicated priority support to ethnic minority groups for their engagement in national forestry programmes such as forest allocation in which tasks of forest protection and on-site management are assigned with priority to these groups and in return these groups receive allowances for their role in forest protection (Decision 1174/2005/QD-T'Tg).

Collaboration with industry is primarily related to timber and eco-tourism. State forestry enterprises and forestry/timber companies are required to collaborate with local authorities and the PPC to apply for and check land administration and ownership status and any landuse issue relating to leasing and using land allocated to households, individuals or ethnic minorities (Decree 135/2005/ND-CP and Decree 118/2012/ND-CP). Organizations and individuals are encouraged to invest money into ecotourism development through joint- 
ventures, cooperatives, and contracts or rental agreements for the forest environment (Decision 104/2007/QD-BNN).

In sum, the Vietnamese government is diversifying the type and number of actors involved in SUF management, with an emphasis on the participation of local resource users. This matches with the wider expectations of co-management. However, while a plurality of actors is referred to, the decision of who participates remains centralised and is not (yet) based on the mobilisation of actors' self-interests and economic motivation. Local participation, coordinated through CPCs, relates to action around forest protection, conservation, wise utilisation of resources, and environmental services. But no-one but the state maintains rights or ownership over SUFs. Furthermore, the government does show a commitment to support the integration of customary with statutory laws. However, it remains unclear exactly how this integration should be practiced. For instance, the notion of 'community' is represented as an instrument of management rather than a set of actors able to exercise rights over forest and forest-land. As a result the practice of customary laws and community-based SUF management appears to be constrained. Similarly, a lack of legal and policy guidance on benefit sharing and reinvestment into SUF conservation appears to limit the incorporation of economic actors in SUFs.

\subsection{Communication and Negotiation}

In contrast to the lack of clarity on pluralism, government policy and legislation is clear on the rights of citizens to be informed about government activities, as well as the benefits of any activities and any impacts (positive or negative) that may ensue (Decision 30/1998/CTTW). Such activities extend to all plans on social-economic development, economic policies, government budgets, investment priorities, master and land-use plans, and infrastructure construction in their communes (Ordinance 34/2007/PL-UBTVQH11). A similar level of transparency is also required in SUF management. Citizens have the right to know about forest allocation in relation to areas assigned as forests, durations of forest protection contracts, tasks in forest protection, and conditions for assignments to households and communities (Decision 106/2006/QD-BNN), specific lease of forest related to ecotourism (Decision 104/2007/QD-BNN), as well as budgets and activities related to forest protection and development across the country, and all agreements on benefit-sharing from forest resources (Decision 126/2012/QD-TTg). All groups and organisations involved in SUFs are held legally accountable to provide information in these activities (Decree 05/2008/ND-CP).

Responsibility for the delivery of information is again state centric, multi-level and predominantly one-way. MONRE, PPCs, DPCs have responsibilities to provide information about national, provincial and district master plans on special use forests on their official government websites (Decree 117/2010/ND-CP; Article 43 of Land Law 
2015). SUF management boards are legally required to spread information of the SUF master plans at on site level (Decree 117/2010/ND-CP). The responsibility for information provision to citizens is devolved to the forestry ranger service who can call village meetings to deliver information (Direction 3714/2011/CT-BNN-TCLN). However, bottom-up communication and negotiation is not directly mentioned in any specific SUF legal text. Instead it is only indirectly referred to in the Law on Complaints, in the regulation on Vietnam Fatherland Fronts, and in the Ordinance on Democracy.

The multi-level Vietnam Fatherland Front is indirectly legitimised to take responsibility for boosting bottom-up communication and negotiation in SUF management. According to the 2015 Law, the Vietnam Fatherland Front is responsible for disseminating public information and mobilizing people in line with the policies of the Party and policies and laws of the State (Article 3). As such the Vietnam Fatherland Front is the political base of the people's administration, with the stated role of representing and protecting the lawful and legitimate rights and interests of the People, rally and uphold the strength of the great national unity, exercise democracy and promote social consensus. However, the Front is also a vehicle for state controlled feedback and protest, by coordinating feedback on concerns relating to the policy and legislation to the Party and the State.

By coordinating grassroots conciliation processes (Article 17), the Vietnam Fatherland Front is one of the ways through which non-state actors are able to provide feedback to governmental authorities. The consequence is that, following this feedback, the government and Party are legally obliged to evaluate their decisions and effects on the rights and benefits of the complaints at hand. In addition, governmental organisations and agencies are required by law to organise meetings for receiving complaints, denunciations, recommendations and feedbacks of the people (Article 59, Law on Complaints, and Law on Meetings with Citizens). In this case, the Vietnam Fatherland Front is responsible for overseeing the enforcement of the law on complaints and denunciations, and encourage and support the people in implementing their rights in this regard (Article 66 of Law on Complaints).

In sum, the Vietnam Fatherland Front is the key actor charged with monitoring commune 'democracy' and facilitating state sponsored two-way communication and negotiation at all levels. This is then executed by the CPC, who is responsible for ensuring that representative processes are put in place and also ensure that the commune level government meets its mandated function relating to public reporting and responding to any feedback from citizens to higher authorities (Direction 30/1998/CT-TW). This also holds consequences for SUF management. Local people are also legitimately enabled to interact proactively with local governments and SUF management boards, especially with mandated support of Vietnam Fatherland Fronts. Actors such as NGOs and economic sectors are mentioned to 
a lesser extent, as none or a very few of the legal documents provide guidance on how they should interact with state authorities and management boards in SUF management arrangements. The focus is especially on local people when it comes to communicating and negotiating issues relating to SUF management and development. However, communication to and negotiation with local people are limited to subjects related to carrying out governmental contracts of SUF forest allocation for household and community protection. And representation, outreach and feedback of all different interests on SUF policies are depended on the accountability and effectively exercised capacities of the CPC and the Fronts at all levels. This altogether might affect the processes of two-way SUF communication and negotiation, because these are mandated indirectly and solely dependent on accountabilities of twisted government actors, especially for the CPCs and Fronts.

Overall, however, the review shows that the state and Party maintains central control over communication and negotiation among SUF actors. It is notable that in legal texts referring to SUFs there is no explicit requirements for two-way communication between the state and non-state actors around SUF management. As a result, there is evidence that processes of communication and negotiation engaged by local people remain limited in practice (Duong Hong Thanh, 2015). This legislative gap means that co-management remains limited to more informative modes of interaction. As I go on to explore in later chapters this has opened up the possibility for NGOs to be more pro-active in facilitating the communication and negotiation between relevant SUF actors. And as noted by (Tan, Chinh et al., 2008), the dominant one-way communication exerted around SUFs, as well as other areas of social existence in Vietnam, is limited by the lack of education and knowledge provided to people about their political rights, which compounds their ability to develop improved two-way communication and negotiation in Vietnam forestry governance.

\subsection{Transactive decision-making}

Transactive decision making processes are evident in a number of areas of policy and law. However, in nearly all cases the decision focuses on obligations and responsibilities for engagement rather than voluntary involvement. A series of rights are stipulated for citizens involved in SUFs to engage in decisions relating to: fee contributions to infrastructure and public welfare constructions in their communes (Ordinance 34/2007/PL-UBTVQH11); discussing and voting on decisions to be ratified by higher level government authorities (Ordinance 34/2007/PL-UBTVQH11); monitoring and implementation of policies at the commune level through officially sanctioned 'voter meetings' (Ordinance 34/2007/PLUBTVQH11). In order to be applied and implemented across the communes, CPCs are mandated to send documents to DPCs for ratification. The documents might be returned for modifications until reaching the agreement with DPCs and these are ratified for implementation (Circular 70/2007/TT-BNN). 
Communities have the right to construct their own local agreement/convention on forest protection and development. Central government has issued an instruction on community forest protection agreement development (Circular 70/2007/TT-BNN; Decision 550/2007/QD-QLR). Governmental organisations support communities with legal advice during the processes of agreement development (Circular 70/2007/TT-BNN). Village leaders are required to gather household representatives to discuss, exchange ideas, and vote over the content of the proposed commune agreements on forest protection and development. If two third of the participants agree upon the proposals, CPCs have to take the documents into account and send them to DPCs for legal checks and ratification, and then implement the legitimated documents across the communities (Decision 106/2006/QD-BNN).

Despite these participative processes being in place, SUF decision making is centralised; and PPCs are charged with making decisions relating to SUFs in provincial administration authority which is assured to be compatible with central governmental decision making. Provincial legal documents aim at clarifying processes of governmental management, protection, and utilization over SUF systems (Decree 117/2010/ND-CP). Commune People's Councils, Commune People's Committees, and the Commune Vietnam Fatherland Fronts are required to assure processes of two-ways communication and negotiation from grassroots to higher governmental levels, assuring local voices to be heard and taken into account in any decision making (Law on organisations of People's Councils and People's Committees 2003). Evidence from other research indicates that many SUF policies, despite appearing transactive on paper, remain top-down in practice. For example, Payment for Environmental Services (PES) schemes have been widely imposed on communities by Decree 99/2010/ND-CP and based on a central governmental recognition of PES benefits rather than on voluntary and/or demand-supply schemes as they are applied in other countries (Do Trong Hoan 2014). Similarly, SUF plans are made that cover long-term landuse of local people, with overlapping land use rights and conflicts (30\% of $128 \mathrm{SUFs}$ ) across the country (Nguyen Hai Van 2014). Again, central top-down decision making tends to overrule the more transactive forms of decision making that are outlined in policy. Systems of local custom, culture and the knowledge of resource-use groups are leaving unsolved how local communities are legitimately integrated and negotiated during processes of transactive decision-making.

\subsection{Social learning}

The promotion of learning processes in SUF management is steered by mandates for research, training and policy review, all of which are steered by the state. However, unlike other co-management characteristics, the responsibility for coordinating learning processes in SUF management is devolved to SUF management boards. The core tasks of 
management boards include cooperation with international nature conservation organisations with a view to transferring new knowledge and information on nature conservation and 'flexibly apply' this knowledge in their own conservation work (Decision 08/2001/QD-TTg). Management boards are also mandated to ensure that eco-tourism activities provide education on nature conservation and raise wider environmental awareness through tourism activities (Decision 104/2007/QD-BNN). Although this process remains devolved, management boards are required to report any exchanges of knowledge and changes in activities to central authorities.

In facilitating learning processes, management boards are required to coordinate a wide group of stakeholders (including scientists, managers, conservationists, and communities) all of which have a reciprocal responsibility to provide knowledge on natural resource management and biodiversity conservation (Decision 08/2001/QD-TTg). These actors are also responsible for reflecting on problems emerging during processes of SUF management and reporting to higher authorities (e.g. MARD and Ministry of Home Affairs) in order to help them understand the practical circumstances and to ask for central solutions and responses (Decision 24/2012/QD-TTg). It is the responsibility of the management boards to document this process (Decision 08/2001/QD-TTg, Decision 192/2003/QD-TTg). As outlined in the above sections on communication and transactive decision making, information is then passed back to management boards and citizens.

This administratively devolved process of learning and reflection has led to changes in problem awareness in SUFs, and subsequent new regulation. These new insights are too widespread to outline in full detail here. But examples include the recognition of insufficient human resources, relating to the forest ranger services (Decision $1717 / 2006 /$ QD-BNN-KL), the lack of professional skill of SUF staff (Decision 1717/2006/QD-BNN-KL; Decision 2740/2007/QD-BNN-KL), and a low awareness of some officers and authorities on tasks of forest protection, allocation and leases (Decision 2740/2007/QD-BNN-KL). Learning about these and other shortcomings has led to new policies, among others on the addition of more than 3000 regular forest rangers in 2015 (Decision 07/2012/QD-TTg), on increasing rights and responsibilities to forest rangers (Decision 57/2012/QD-TTg), and on improvement of the quality of SUF staff (Decision 2370/2008/QD-BNN-KL). Other areas where changes have been made include financial arrangements for staff working in SUFs (Decision 192/2003/QD-TTg), and funds for SUF management and development (Decision 192/2003/QD-TTg). This has led to the allocation of more stable governmental budgets to SUF management boards (with an increase in average budget to $100,000 \mathrm{VND} / \mathrm{ha} /$ year (about 4,5 USD/ha/year) and investments in SUF village community co-management of 40 million VND/village/year (about 1,700-1,800 USD/village/year). In addition, a decision was made to return $75 \%$ of the revenues from ecotourism to SUF funds (Decision 24/2012/QD-TTg). 
Changes have also been made relating to the management of SUFs. Government decisions have been updated around collaboration between communities, districts and province, the need for 'interdisciplinary management' between central government and People's Committees at all levels and international organisations (Decision 192/2003/QD-TTg), as well as the need for improved coordination with relevant branches of government (Decision 192/2003/QD-TTg) and more effective law enforcement (Decision 192/2003/QD-T'Tg; Directive 1685/2011/CT-TTg). However, it appears that these changes have led to greater, and not less, control by the central government. MARD is now identified as the main government body in charge of SUF management (Decree 117/2010/ND-CP), while MONRE has been given greater control over land and biodiversity management (Law on Biodiversity 2008). This in turn has led to greater oversight on management measures and responsibilities (Decision 07/2012/QD-TTg).

By investing in these improvements the government aims to transform forest protection from fully state-based to co-management arrangements involving local communities (Decision 57/2012/QD-TTg). However, it is also apparent from the review that 'learning' has been limited to administrative processes relating to government control and the introduction of market incentives through, for example, benefit sharing mechanisms for non-timber forest product harvesting and PES schemes. (Decision 126/2012/QD-TTg; Decision 126/2012/QD-TTg). Some crucial requirements and lessons for co-management arrangements to learn and enable greater and more equal interactions among actors are not yet covered in policy or legislation. The result is a lack of attention to how local and scientific knowledge can be integrated in SUF policies, and how policy modifications in relation to SUF property rights and ownership can result in more effective outcomes.

\subsection{Shared actions and commitments}

Administrative control over co-management means that shared actions and commitments are mandatory rather than voluntary. 'Benefit sharing' has emerged in policy and legislation in recent years as a main approach to implementing shared actions between the state and resource users. However, the practice of benefit sharing in SUFs has faced contradictory policy and legislation (PanNature 2014). Implementing schemes to ensure shared use of these resources appear to run counter to strict controls over wood exploitation, forest product harvests, and wildlife animal hunting (Decree 32/2010/ND-CP and Decision $2243 / 2014 /$ QD-TTg). Coupled with the low capacity of law enforcement and weak commitments, debates over benefit sharing have also been linked to debates on the overexploitation of forest resources (PanNature 2014). To address these potential contradictions the government has turned to providing income streams from indirect sources related to natural resources such as PES and ecotourism, and controlled forms of forest allocation and cultivation (Decision 104/2007/QD-BNN). However, the lack of 
clarity on SUF ownership and management have constrained the implementation of benefit sharing schemes like PES in many SUFs across the country (Nguyen Hai Van and Nguyen Viet Dung 2015).

The implementation of benefit sharing mechanisms is directed by MARD and involves the SUF management boards, PPC, DPCs, CPCs and village communities. These mechanisms focus on SUF products such as forestry and fisheries and rights on animal and plant cultivation. SUF management boards remain in charge of management, while CPCs are listed as beneficiaries boosting the effective engagement of local people. The implementation of these mechanisms represents a shift from a centralized national budget under what was known as the five-million-hectares programme up till 2010 (Program 661), to an average budget of $100,000 \mathrm{VND} / \mathrm{ha} /$ year delivered to qualifying households, communities and security units (Decision 24/2012/QĐ-TTg; Article 191, Land Law 2013). In this sense benefits are shared between the government and local resource users with the goal of SUF protection and livelihood development. In this sense, local people help the government to overcome governmental barriers of human resources for SUF protection and in return they gain some rights for their SUF resource exploitation which was previously strictly prohibited by SUF policies. This attempts to create incentives for local people livelihood development based on SUF resources with the hope to increase commitments of local people in SUF protection. However, as outlined by (Nguyen Hai Van and Nguyen Viet Dung 2015) all costs of SUF management remain in charge of SUF management boards based on their annual allocated budgets from both national and/or provincial levels - which are in practice just enough for operations of the Boards

To engage in benefit sharing households require a so called "red book" land contract, which stipulates a long-term lease. Communities can also use land in SUF rehabilitation zones for specific activities such as forest plantation and protection (Decision 13-2013QH13 - Land Law 2013; Decree 43/2014/ND-CP). Through these contracts both households and communities are permitted to benefit sharing as long as activities contribute to long term forest protection (Decision 29/2004/QH11 - Law on Forest Protection and Development 2004). All activities related to the assignment of land-use contracts is controlled by the government who documents allocation by defining and registering boundaries and benefits (Decision 106/2006/QD-BNN dated 27/11/2006). By having a contract, both households and communities are also able to participate in PES schemes (Decree 99/2010/ND-CP on the policy of Payment for Forest Environmental Services). However, these PES schemes are limited because "red book" contracts do not allow for the transfer of ownership rights, which remain with the state (Wunder, Dung et al., 2005); Article 29 and 30 of Law on Forest Protection and Development 2004). Other activities like ecotourism are also a direct means of benefit sharing. Here the government defines the terms and provides direct support to community-based ecotourism 
development (Decision 44/2005/QH11 - Law on Tourism; Decision 104/2007/QD-BNN dated $27 / 12 / 2007)$. Under the Law any stakeholder that engages in tourism related business involving SUF resources are required to provide local people with engagement in tourist services (Decree 23/2006/ND-CP; Decision 104/2007/QD-BNN) and support them to enhance their benefits, livelihood development, and responsibilities in nature conservation (Decision 104/2007/QD-BNN).

In summary, incentives for shared action and commitment to SUF management are facilitated through benefit sharing mechanisms. However, these mechanisms have not yet created a transformation SUF management in boosting the involvement of local people because of weak institutions around ownership and user rights. This means that in spite of the rhetoric surrounding 'benefit sharing' local people largely form hired labour for the state. The lack of shared action for SUF management is in this sense also limited by the slow transfer of wages to local people, as well as the weak policing of illegal exploitation of SUF natural resources (Vu Thi Bich Thuan, 2015), and conflicts over rights of SUF land use (Nguyen Hai Van and Nguyen Viet Dung, 2015). Clear design and enforcement of policy and legislation therefore appear to be required if benefit sharing arrangement for SUFs is going to better facilitate a shift to co-management.

\section{Discussion}

The review demonstrates that there is a legal foundation for the development of SUF comanagement. In Vietnamese policy and legislation the type of co-management tends towards what has been labelled an instructive model - that is, a model with only minimal exchange of information between government and users (Sen and Nielsen, 1996). Also corresponding to the literature on co-management, there are mechanisms for creating dialogue with resource users, but Vietnamese policy focuses predominantly on government informing resource users on decisions and coordinating participation (Lai, 2008; Duong Hong Thanh, 2015; Hoang Van Nghia, 2015). Yet despite evidence of this instructive model, the government has in place a series of policies which distribute implementing responsibility away from the central or national level towards commune level organisations and SUF management boards. There is also emphasis on the inclusion of non-government organisations, including extensive attention to citizen engagement and businesses. What remains unclear is whether the policies and legislation reviewed, albeit still highly centralized in terms of key decision making power, allow for any form of locally adaptive decision making? 
All characteristics of adaptive management are observable in policy and legislation, but shaded by the instructive model of co-management. The review shows that pluralism is promoted in policy, but that the government continues to hold control over how different stakeholder groups can access co-management arrangements. The government maintains a centralized long-term planning model and although input is sought from citizens and other groups it is done through line agencies spanning multiple levels of government (in line with the vision of USAID's Coral Triangle Support Partnership 2013). Yet direct participation by resource users is also mandated, not voluntary. The result is that any deviation from policy can result in modifications or withdrawal of land rights and forest ownership. NGOs and civil society organisations have a passive participation in co-management, with their legal obligations limited to information provision and knowledge sharing (Pomeroy, 1995). Democratic processes are maintained through the Ordinance of Democracy, which facilitates a degree of transactive decision-making in terms of assuring interactions, hearings, and opinion searching. Here again the government stipulates consultation rather than a shared decision framework (cf. Berkes, 2010). Final decisions on nearly all issues relating to SUF management are taken at the national and provincial levels. While 'learning' is supported through reporting and information exchange it does not yet appear to promote a social form of learning where on-going knowledge creation leads to shared values and jointly implemented actions (Plummer and FitzGibbon, 2004a; Pahl-Wostl, Sendzimir et al., 2007). Instead feedback aims to strengthen central planning and implementation. Finally, in terms of shared actions and commitments, government has instituted the language of 'benefit sharing', but has mandated and controlled sharing rather than allowing for voluntary allocation and market transfers. This again has allowed for an instructive and only very weakly adaptive model of co-management.

A series of key observations can also be drawn from the review that underlie the lack of development of co-management. First, the review illustrates the tension between decentralization and centralization of SUF management. In Vietnam, decentralization and the delegation of authority is regarded as an important political task in a process of governmental administration innovation (Phuong, 2013). While the government may be willing to call for more participation, it appears reluctant to delegate significant authority to manage natural resources to local communities and organisations (Pomeroy, 1995). This is reflected throughout the reviewed policy and legislation. Yet, while administrative decentralization was more evident, the delegation of authority to the extent of selfmanagement is not yet in use in the political and legal texts (Phuong, 2013). Instead what is observed is the allocation of tasks without decision making authority. Administrative delegation observed is limited to provincial level government through the PPC. Legislation and policy on local level resource use refers to various obligations of households and communities. As argued above, these obligations reinforce the control of the state and relegates citizen engagement to state instruments rather than self-managed units with clear 
mandates for contributing to SUF sustainability. Under such conditions the emergence of co-management that creates deliberative inclusion of a wide set of stakeholders appears limited (cf. Finkbeiner and Basurto, 2015).

Second, the review highlighted the overlapping mandated responsibilities of governmental agencies, causing a paradox between rhetoric and reality in biodiversity conservation and environmental protection in terms of practicing truly collaboration among the organisations (IUCN, 2010). SUF management boards are both forest owners while they are also tasked with responsibilities related to social service provision. The practical implication is that many of the same organisations that management boards partner with are also responsible for both enforcement and livelihood development. Not only is there no clear boundary between the two responsibilities at the level of these management boards, the direct responsibility of land and forest management is allocated to two different central organisations - MARD and MONRE. The lack an effective collaboration between these ministries further compounds the challenge SUF management boards have to complete management tasks, let alone to invest in social service provision (Nguyen Thanh Huyen, 2013; Nguyen Viet Dung, 2014). This conflict of interest means that co-management remains confounded in policy and creates considerable limitations for local practice.

Third, the review draws out underlying problems relating to the lack of clarity around property rights, which has undermined attempts by management boards to engage communities in co-management (Doan Diem, 2014). According to To Xuan Phuc (2014), what is required is a clearer delineation in policy and law about who the "real SUF owners" are. Without this clarity key characteristics of co-management will be undermined - in particular policies relating to benefit sharing (To Xuan Phuc, 2014). One area that needs more attention is the inclusion of customary laws into SUF policy and legislation (Nguyen Thanh Huyen, 2013). As the review demonstrates, the Vietnamese government has focused on statutory laws for SUF management. While pluralism is addressed, and even the greater inclusion of ethnic minorities, there is no attention to the diversity of customary practices and laws, nor how they could be included into a co-management arrangement. This would be an important first step in the further development of policy and legislation related to SUFs.

\section{Conclusion}

Although the concept of co-management has been used in Vietnam for the last 20 years it remains largely underdeveloped in government policy and legislation. Nevertheless, the review also demonstrates that there is support, albeit scattered and uncoordinated across a 
range of policies and laws, for the development of co-management. If considering comanagement as a process, better refinement of this legal framework could help to better institute co-management. Although there is no precise guidance for SUF co-management installation and development, the five characteristics of co-management are partially visible in these documents. However, to further improve this attention needs to be given to ensuring that a framework for communication and negotiation with local resource users is developed that more clearly sets out the right of dialogue and the accountability of government organisations. Legal permission for constructing village conventions and agreements on forest protection would also be an important starting point for developing more consultative and interactive forms of co-management. Difficulties emerging from the process can be fixed by enhancing law enforcement and capacity, mobilizing outside supports, and creating mechanisms for information transparency. These results can provide a useful starting point for both governmental agencies and NGOs who are attempting to install co-management in Vietnamese SUFs.

In the following chapters, we build on this review by present the results of three empirical studies that explore the extent to which co-management has been implemented. In particular I explore what possibilities there are for shaping current Vietnamese legislation and policy towards a more adaptive form of co-management. The next chapter provides empirical data on the current practice of SUF co-management across the country, focusing on the extent to which the state and NGOs take up their mandated roles. In doing so this chapter provides a diagnosis of how the current policy and legislative framework directly facilitates the dysfunctional performance of SUFs. 


\section{Chapter 3}

\section{ADMINISTRATIVE CO-MANAGEMENT: THE CASE OF SPECIAL-USE FOREST CONSERVATION IN VIETNAM ${ }^{1}$}

\section{Introduction}

In Vietnam, special-use forests (SUFs) are considered 'the backbone of the national protected areas system' (PARC, 2006), comprising terrestrial forests, and a number of wetland and marine areas (ICEM, 2003). Since 1993, the Vietnamese government has strengthened the special-use forest system to meet obligations of the Convention on Biodiversity (CBD) and the Ramsar Convention by increasing the total surface area of protected areas to two million hectares (ICEM, 2003; Zingerli, 2005; Meyfroidt and Lambin, 2008). However, despite this significant increase, and early reports of a shift from net deforestation to reforestation (Meyfroidt and Lambin, 2009), conflicts persist around SUFs as forest habitat is degraded by illegal logging, trade and transportation of forest products in many parts of the country (VEPA, 2007). It remains clear that a national response to curbing biodiversity loss and degradation of forest habitat is needed.

Ineffective management of SUFs has been fueled by a combination of poorly funded surveillance and the dependence of local communities on forest resources for their livelihoods. Conflicts have commonly ensued between local users and authorities responsible for nature conservation when the former have been forcefully excluded from protected areas (Zingerli, 2005). Other evidence has pointed to the lack of alternative income opportunities for communities living around SUFs as a cause of continued levels of exploitation (Boissière, Sheil et al., 2009). In Vietnam, like many other developing countries (Hayes, 2006), prohibiting natural resource use in protected areas provides no incentive for responsible and sustainable use; rather, local residents maximize resource exploitation as opportunities arise.

Faced with these challenges the Vietnamese government, in collaboration with a range of international conservation organizations, has attempted to institutionalize co-management in SUFs to engage local stakeholders in protected area management and improve the protection of forest habitat and biodiversity (Boissière, Sheil et al., 2009). In 2003, the

\footnotetext{
${ }^{1}$ This chapter has been published as KimDung, N., Bush, S., \& Mol, A.P.J (2013). Administrative co-management: The case of special-use forest conservation in Vietnam. Environmental Management, 51(3), 616-630.
} 
Government ratified the Management Strategy for Protected Area System in Vietnam up to 2010 , in which an approach of co-managing protected areas is portrayed. The Strategy addressed issues of co-management, such as a clear identification of roles and responsibilities of communities, the promotion of local resource user involvement, and the reformation of policy and institutions to strengthen state management and local authority capacities (Government of Vietnam, 2003). According to Swan (2010), the 2004 Land Law identifies communities as legal entities with rights to hold long-term land leases, which provides a fundamental change for the development of terrestrial co-management models (Swan, 2010). In addition, subsequent implementation of co-management has been coordinated by the Ministry of Agriculture and Rural Development (MARD, 2005) and the Vietnam Conservation Fund (VCF) in reference to the Vietnamese government's obligations under the CBD Program of Work on Protected Areas (IUCN, 2006), as well as through a number of foreign-funded pilot SUF co-management projects (Wyatt and Quan, 2007; Sandbrook, Trong et al., 2010). Despite the ongoing conflicts associated with illegal use of SUF resources a shift from the conventional government-monopolized conservation paradigm to an alternative co-management system appears to be underway in Vietnam.

Co-management has been introduced into Vietnamese SUFs management with a normative emphasis on finding 'win-win' solutions that could link conservation and development activities, boosting the roles and functions of the protected area system to support the implementation of the Comprehensive Development and Hunger Eradication and Poverty Reduction Strategy in the course of national industrialization and modernization (Sunderlin and $\mathrm{Ba}, 2005)$. However, experience from other parts of the world have shown that successfully co-management of natural resources requires a certain socio-economic and political context, in which decentralization is the linchpin (Borrini-Feyerabend, Pimbert et al., 2004). As Campbell and Vainio-Mattila (2003) note, decentralized control and decision making through co-management can improve the welfare of local communities (Campbell and Vainio-Mattila, 2003). Therefore, it can be questioned whether co-management arrangements for nature protection in a central state-organized country as Vietnam will look similar to those in the market-oriented liberal democracies of Europe and Northern America. Because the ways and the extent to which co-management has been institutionalized across the country is unknown, with most information derived from a relatively small number of case studies, this paper provides a country wide analysis of comanagement in SUFs and in doing so specify the characteristics of a Vietnamese brand of co-management and contribute to a better understanding of the ongoing changes to Vietnamese nature protection. The following two sections provide a background to the SUF system in Vietnam and a theoretical typology of co-management. We then use this typology to analyze the results of a survey of 105 SUFs before outlining a new form of comanagement for Vietnam. 


\section{The special-use forest system in Vietnam}

Vietnam started nature protection in 1962 with the establishment of its first 'prohibited forests' in what is today the Cuc Phuong National Park. Until 1986, the system of prohibited forests was comprised of 87 areas across the country, classified as national parks, nature reserves, and cultural, historical and environmental areas (Dung, Bao et al., 2002). At the end of 1986, Vietnam's Ministry of Forestry (MARD today) issued Decree 1171-QD on the regulation of three types of forests, in which the term 'special-use forests' was introduced to distinguish from protection forests ${ }^{2}$ and production forests. In the regulation, SUFs were defined as national forests established to protect and conserve forest habitats, the genetic resources of endemic flora and fauna, landscapes, and sites with cultural and historic value, as well as often also providing resources for scientific research and education (MoF, 1986).

Since 2010, 161 SUFs (making up 2,198,744 hectares) have been identified and classified into national parks (30), nature reserves (55), species and/or habitat reserves (11) and landscape protected areas (45). These SUF areas include not only entire forests, as the name implies, but also many cultural and historic sites, grasslands, freshwater lakes, and coastal and marine areas (MONRE, 2011b; PanNature, 2011a). ${ }^{3}$ National parks have been defined as areas with large typical ecosystems, containing high values for science, education, and tourism. Nature reserves are wilderness areas designed to maintain ecological processes through the restoration of natural resources and biodiversity, and species and/or habitat reserves for endemic or valuable flora and/or fauna. Cultural-historic-environmental areas (or landscape protected areas), consist of landscapes with a high aesthetic value (often associated with cultural and historic values), that serve culture, tourism or science (Government of Vietnam, 2001).

National management and administration of SUFs is fragmented, and the division of responsibility between the central and lower administrative levels unclear. MARD is responsible for the systematic administration of SUFs and also administrates eight interprovincial national parks. Within MARD, the Forest Protection Department (FPD) plays a key role in monitoring and managing the SUF network (Government of Vietnam, 2003).

\footnotetext{
${ }^{2}$ In Vietnam, protection forests are classified for upstream watershed protection forests, anti-shifting sand forests and coastal wave-breaking forests.

${ }^{3}$ In January 2011 the government enacted Decree 117/2010/ND-CP on the organization and management of SUFs. In doing so it also introduced experimental research forests as a new category of special-use forest. However, the jurisdiction of this category remains ambiguous as it has not yet been drafted into the 2008 Law on Biodiversity.
} 
Responsibility for other protected areas is divided among other branches of the government. Wetland conservation and protection is divided between the Ministry of Natural Resource and Environment (MONRE), responsible for 'sustainable development', while MARD maintains control over wetland protected area protection (VEPA, 2005). MARD also cooperates with the Ministry of Fishery on wetland resource management and protection (Government of Vietnam, 2001), and the latter is also the main authority responsible for marine protected areas (PARC, 2006). The Ministry of Culture and Information (MOCI) directly administrates landscape protected areas, but does so in cooperation with MARD who maintains managerial responsibility for protection.

At the provincial level, the Provincial People's Committees (PPCs) ${ }^{4}$ is responsible for all other SUFs. Based on the size and importance of forests, PPCs might assign district governments to manage and develop activities such as tourism (Government of Vietnam, 2001). According to Swan (2010), the majority of Vietnam's SUFs are managed by provincial Departments of Agriculture and Rural Development (DARDs), under their respective People's Committees. However, SUFs, not managed by the District level Forest Protection Department, report directly to PPCs. At the operational level, the management board of a SUF is staffed by officials assigned by provincial DARDs and is responsible for management and protection (ICEM, 2003). The board does not include representatives from other sectors or stakeholders. Where management boards have not been established, SUFs are under the management authority of either District Forest Protection Departments, Provincial Departments of Agriculture and Rural Development, or Provincial Departments of Culture and Information (Government of Vietnam, 2003).

In short, human activity in national parks, nature reserves, and species and/or habitat reserves are restricted to nature protection rather than resource use, while in culturalhistoric-environmental areas regulation includes cultural and tourist activities. Despite the poor representation of local people in SUFs, co-management appears to remain an important strategy given that up to $80 \%$ of Vietnam's SUFs are estimated to be legally inhabited (Cuong, Dung et al., 2009). Research has shown that areas surrounding these forests commonly consist of agricultural lands, housing and infrastructure. However, although often legal, the close proximity of human occupation in these border and buffer areas of protected zones are also often ill-defined. Surrounding communities are bound by law to protect the resources and biodiversity in the forests, but illegal poaching, hunting, cultivation and/or logging is highly prevalent (PARC, 2006). Given the conflicts in and

\footnotetext{
${ }^{4}$ In Vietnam, the Provincial People's Committees are state administrative organs in provincial levels, operating functions of state management under provincial administrative boundaries, and ensuring the integration of administration and direction from the state to grassroots' levels.
} 
around SUFs defining the potential of co-management that would suit the Vietnamese context appears more necessary than ever.

\section{Co-management research framework for Vietnam}

The concept of co-management was introduced in the early 1990 s by core group of scholars (Berkes, George et al., 1991; Pomeroy, 1995; McCay and Svein, 1996; Sen and Nielsen, 1996). The concept has been widely used in natural resource management literature, especially with respect to fisheries and forestry. Today, co-management is strongly related to the adaptive governance literature, where multiple actors at multiple levels continuously interact to solve problems and adjust their positions and activities to respond to changing circumstances (Carlsson and Berkes, 2005). Reflecting this wide scope, Plummer and FitzGibbon (2004b) argue that a broad definition of co-management is preferred, namely, the distribution of rights and responsibilities pertaining to a particular resource among governments and local users.

The co-management typology of Berkes and colleagues (1991) characterizes seven modes of co-management: Information, consultation, cooperation, communication, advisory committee, management boards, and joint decision-making. These modes characterize different levels of information exchange and feedback amongst government and resource users. As such, each emphasizes the extent to which resources are shared in decisionmaking. According to Notzke (1995), these seven modes are useful in illustrating the diversity of co-management but are not easily distinguished in practice. Sen and Nielsen (1996) therefore introduced a classification of five types of co-management arrangements, namely instructive, consultative, cooperative, advisory, and informative, moving from state management to community-based co-management. These arrangements differ in the degree of power sharing between government and resource users by focusing on decision-making and management tasks with respect to planning, implementation and evaluation. Although these classifications identified and examined power as a critical element of co-management, Hersoug and Rånes (1997) argued soon after that they are too simplistic and insufficient to deal with complexities such as time, scale, and representation.

Plummer and FitzGibbon (2004a) subsequently addressed the complexity of comanagement by developing a framework that incorporates a diversity of interests and inputs, the operationalization of power, and a process of learning in order to adjust and adapt. They identify five characteristics of co-management: pluralism, communication and negotiation, transactive decision-making, social-learning, and shared actions or commitments. Pluralism relates to the inclusion of various interests and/or inputs in the, 

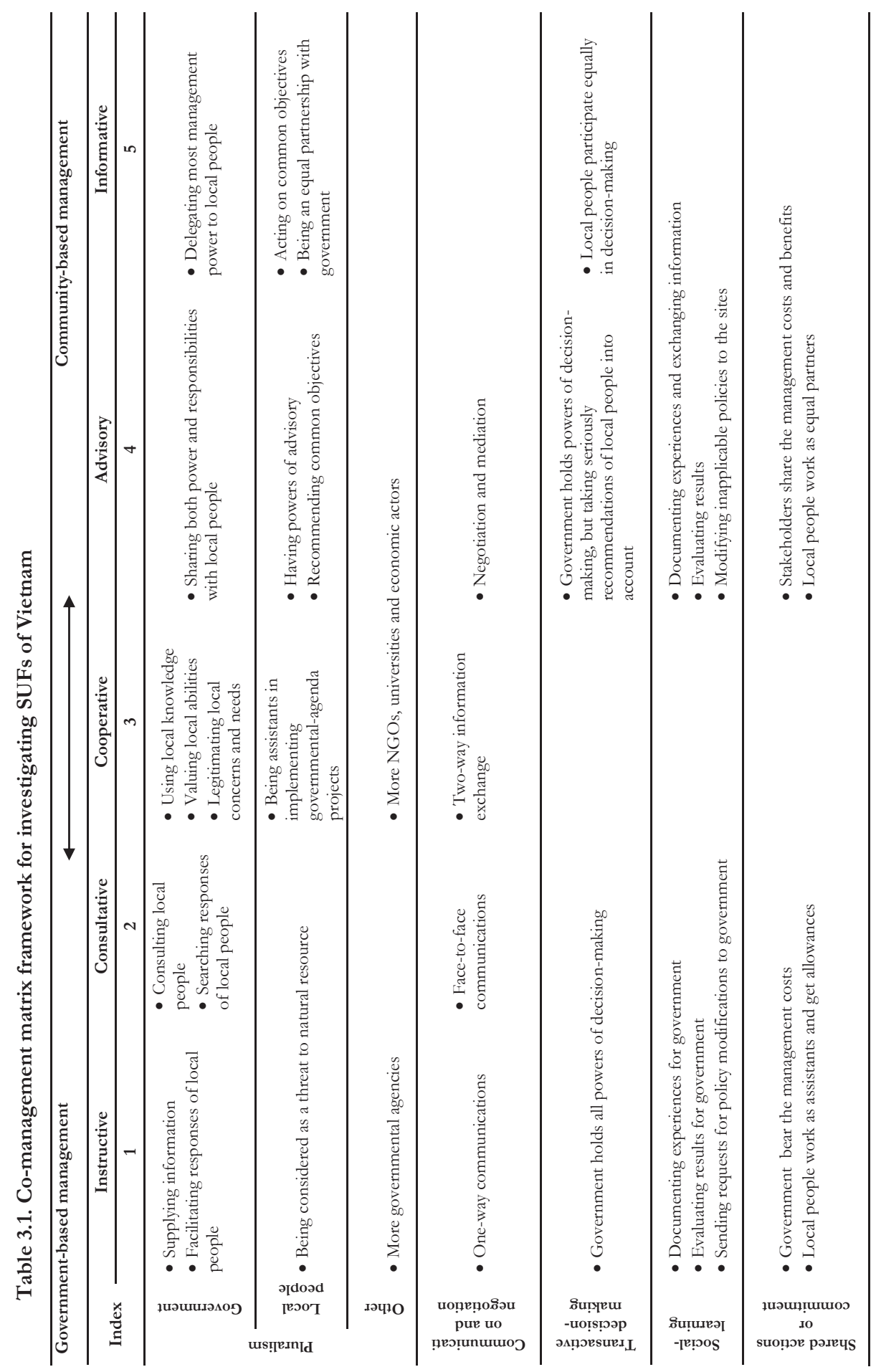
process of co-management. Communication and negotiation refers to information exchange and feedback to gain consensus and common understanding amongst stakeholders. Transactive decision-making focuses on the process of decision-making, in which information from multiple types of knowledge contribute to more equitable and efficient co-management processes. Social-learning refers to on-going knowledge creation by sharing values, jointly implementing actions, and reflecting upon feedbacks. Finally, shared actions or commitments refer to the willingness of all actors to undertake joint activities which under collaborative forms of management.

In this paper, we employ Plummer and FitzGibbon's five characteristics of co-management as a basis for analyzing SUFs in Vietnam. We combine these characteristics with the types of co-management classified by Sen and Nielsen (1996) into a conceptual matrix (Table. 3.1). The horizontal axis represents a scale of co-management based on Sen and Nielsen's classification, ranging from government-based management system to a community-led comanagement. The characteristics of co-management then correspond to the vertical axis, providing a qualitative measure of the degree to which power is shared between government and local people along the five co-management types. Together these axes allow us to map the extent to which Vietnam has shifted the SUF management from a centralized government-based system to a co-managed system of forest governance.

\section{Methods}

The methodology was based on a national survey of managers directly responsible for management in the 143 SUFs across the country (following a draft version of the 2010 SUF list of the Forest Protection Department, excluding the 20 experimental research forests). Based on the assessment matrix (Table. 3.1), and combined with our own experiences of nature conservation in Vietnam, a structured questionnaire was developed with a total of 37 questions, of which 16 questions were used to develop an index of co-management arrangements.

After initially contacting the heads of SUF management boards to explain the purpose of the survey, a questionnaire (in Vietnamese language) was sent by post. This two-step process, combined with some follow phone calls to remind the respondents to complete the questionnaire, ensured a high rate of response. After removing incomplete surveys, the final response rate to the questionnaire was 105 or $73 \%$ of our target; of which 24 were national parks (out of a possible 30; 80\%); 45 nature reserves (out of a possible 57; 79\%); eight species and/or habitat reserves (out of a possible 11; 73\%); and 28 landscape protected areas (out of a possible $45 ; 62 \%$ ). 
In-depth interviews were subsequently conducted with 22 randomly selected members of SUF management boards to validate survey questions and gather more detailed information on the collaboration between management boards and other stakeholders. Approximately half of these interviews were conducted face-to-face, while the other half were conducted via telephone.

Data analysis started with descriptive statistics before moving to the construction of the comanagement index based on 16 questions from the questionnaire. These questions were divided between the characteristics of co-management on the vertical axis of the matrix (see Appendix 6). Scores on these questions were then allocated along the horizontal axis of the co-management matrix, ranging from 1 (Instructive) to 5 (Informative). Equal weights were given to each of the five theoretical characteristics of co-management. But within each characteristic questions were weighted according to their importance reflected in the comanagement literature and by Vietnamese practitioners (see Appendix 6).

Pluralism was measured based on the diversity of collaborations between the management boards and other stakeholders, in terms of levels (local, national, regional, and international) and sectors (military, economic sectors, education and science sector, and civil organizations). The more diversified collaborations regarding levels and sectors, the higher the degree of co-management. We used one question to identify and classify stakeholders having formal and informal collaborations with the management boards.

Communication and Negotiation refers to information exchange and feedback amongst stakeholders to gain consensus and common understandings on the management of SUFs (Plummer and FitzGibbon, 2004a). We measured these two variables through four separate questions related to communication and negotiation. The first question tested the extent to which park managers seek guidelines for their activities from the central government. A low score implies the existence of one-way communication and a top-down mode of decisionmaking and management. The second question focused on the modes and methods of information exchange and feedback between actors involved in management. We considered a higher diversity in these modes and methods to imply that information exchange is more interactive amongst stakeholders. Differences between different modes of information exchange were also taken into account; for example, paper reports were deemed less interactive than site visits. The third question focused on the frequency of meetings between stakeholders. Here we assume that the more frequent the meetings the more information exchange and feedback occurs. Finally, the roles of participants and the ways of communication in meetings on resource management are reflected in a question distinguishing the mode of interaction in these meetings, ranging from one-way passive exchange to multi-lateral interactive exchange. 
Two questions in the survey explored the desire for improving transactive forms of decision-making in the management of SUFs; i.e. the ways in which multiple types of knowledge are used to reach equitable and effective management outcomes (Plummer and FitzGibbon, 2004a). The first question focuses on what demands park managers place on the devolution of decision making and authority. The second focuses on the degree of freedom park managers have to react to novel situations without deferring to higher levels of government. It was expected that a demand for devolution of authority implies that power is currently not equally shared and operational levels of decision making at the level of SUFs remain centrally controlled. It was therefore anticipated that if operational levels of management are more free to react to new situations, this would demonstrate less central government control. In order to understand the roles of stakeholders and how power is distributed in making decisions in SUF co-management arrangements, the survey also investigated eight commonly employed tasks in co-management arrangements: resource estimation, access right formulation, harvesting regulation, market regulation, monitoring, enforcement, evaluation, and policy modification (Sen and Nielsen, 1996). However, these were used for clarifying the results rather than in the scoring.

Social-learning in co-management is a measure of the ability of stakeholders to develop knowledge through the process of (co-)management by sharing values, implementing activities, and reflecting upon feedback (Plummer and FitzGibbon, 2004a). The degree of social learning in SUFs was measured through four questions: (1) the extent to which management experiences were documented by managers for later reflection or reference, (2) whether the relevance of policies implemented in the area are evaluated, (3) the responsiveness of stakeholders to modifications to government policy, and (4) the responsiveness of higher authorities to events or management problems. It was assumed that the documentation of experiences would increase the likelihood of fostering learning by managers and resource users alike. Moreover, learning by government authorities is assumed to provide a basis for adequately evaluating the extent to which policies are applicable to specific sites. The more responsive managers are at the operational levels, the more effective co-management should be.

Finally, shared actions or commitments refers to the extent to which stakeholders have agreed to and take part in joint activities. The five questions used to evaluate this characteristic of co-management referred to: (1) the costs associated with management; (2) the degree of recognition given to local people's rights, (3) the degree of recognition given to historical values and indigenous customs, (4) the economic incentives used in management, and (5) the extent to which local people join in management tasks. By investigating management costs we assume that sharing responsibilities and benefits creates financial efficiencies in management. We also assume that as governmental authorities 
recognize the rights, benefits, historical values and indigenous customs of local people, and furthermore, that collaboration amongst local people and government results in effective co-management. Economic incentives are assumed to motivate stakeholders to collaborate with managers and the greater the role resource users play in management tasks the more likely co-management is to succeed.

Mann-Whitney Tests and Kruskal-Wallis Tests were employed to compare differences between categories of SUFs. These tests are applicable to our data because they allow for comparison of two or more independent groups with different samples sizes, of which the data are ordinal, not normally distributed, and contain outliers.

\section{Results from the survey}

The overall result of the survey is that with a score on our index of $3.06(S D=0.30, n=$

105) co-management in SUFs most closely corresponds to Sen and Nielsen's form of 'cooperative' - positioned between the two extremes of government-based and community-based management forms of co-management. The variation of co-management arrangements are represented at both extremes of the range of results by the Vinh Cuu nature reserve (Dong Nai province), with the highest score (3.75), and Krong Trai nature reserve (Phu Yen province), with the lowest (2.25). Table 3.2 below presents the overall descriptive statistics of co-management over the five point index and over the four categories of SUFs. 
Table 3.2 Levels of co-management in SUFs of Vietnam, according to dimensions and categories of special-use forests

\begin{tabular}{lccccc}
\hline & $\begin{array}{c}\text { National } \\
\text { parks } \\
(\boldsymbol{n}=\mathbf{2 4})\end{array}$ & $\begin{array}{c}\text { Nature } \\
\text { reserves } \\
(\boldsymbol{n}=\mathbf{4 5})\end{array}$ & $\begin{array}{c}\text { Species } \\
\text { and/or } \\
\text { habitat } \\
\text { reserves } \\
(\boldsymbol{n}=\mathbf{8})\end{array}$ & $\begin{array}{c}\text { Landscape } \\
\text { protected } \\
\text { areas } \\
(\boldsymbol{n}=\mathbf{2 8})\end{array}$ & $\begin{array}{c}\text { Overall of } \\
\text { protected } \\
\text { areas } \\
(\boldsymbol{n}=\mathbf{1 0 5})\end{array}$ \\
\hline Pluralism & 3,21 & 2,20 & 1,75 & 1,79 & $\mathbf{2 , 2 9}$ \\
Communication & $(S D=1.38)$ & $(S D=1.27)$ & $(S D=0.89)$ & $(S D=1.07)$ & $(S D=1.32)$ \\
and Negotiation & $(S D=0.56)$ & $(S D=0.54)$ & $(S D=0.88)$ & $(S D=0.64)$ & $(S D=0.63)$ \\
Transactive & 2,50 & 2,77 & 3,00 & 2,54 & 2,66 \\
Decision-making & $(S D=0.64)$ & $(S D=0.67)$ & $(S D=0.46)$ & $(S D=0.69)$ & $(S D=0.67)$ \\
Social-learning & 3,55 & 3,49 & 3,91 & 3,45 & $\mathbf{3 , 5 2}$ \\
Shared actions or & $(S D=0.54)$ & $(S D=0.56)$ & $(S D=0.57)$ & $(S D=0.75)$ & $(S D=0.62)$ \\
Commitments & 2,64 & 2,75 & 2,81 & 3,00 & $\mathbf{2 , 7 9}$ \\
Overall score & $(S D=0.49)$ & $(S D=0.49)$ & $(S D=0.42)$ & $(S D=0.36)$ & $(S D=0.47)$ \\
& $\mathbf{3 , 1 2}$ & $\mathbf{3 , 0 8}$ & $\mathbf{3 , 0 5}$ & $\mathbf{3 , 0 0}$ & $\mathbf{3 , 0 6}$ \\
& $(S D=0.23)$ & $(S D=0.33)$ & $(S D=0.21)$ & $(S D=0.34)$ & $(S D=0.30)$ \\
\hline
\end{tabular}

\subsection{The Pluralism of Vietnamese protected areas}

Overall, pluralism scored lowest among the five co-management dimensions of SUFs. However, within the category national parks score the highest with a statistically significant higher level of pluralism than nature reserves $(U=321.5$, p-value $=0.005)$, species $/$ habitat reserves $(U=39$, $p$-value $=0.011)$, and landscape protected areas $(U=148$, $p$-value $=0)$. No statistically significant difference was found between pluralism of nature reserves, species and/or habitat reserves, and landscape protected areas (Figure. 3.1; see Appendix 6 for all the mean values and standard deviations).

The results also indicate that all groups are not equally evident in management across all four SUFs categories (Table 3.3). Besides administrative governmental agencies, SUF management predominantly legally engaged local people, police, and the military in forest protection and conservation, and to a lesser extent public and private enterprises, civil organizations, scientific and education organizations, and international actors. While overall there seems to be some degree of pluralism in protected areas, this finding is in need of further qualification. Local people's involvement was seen across all national parks and $96 \%$ of all SUFs. However, collaboration by state or state-related organizations (the military, the police, state economic sectors) is more significant than private enterprises or international organizations. The police and military participated in and collaborated with the management boards and forest rangers because forest rangers have no authority to 
order an arrest or enforce fines. The military and police are also crucial in fire management. The Vietnamese Father Front and civil organizations, such as the Youth Union and Women Union, are related to the Vietnam Communist Party and help to disseminate information and raise awareness related to rare and endangered species protection, wildlife protection, and environmental protection.

\subsection{Communication and Negotiation}

The average score for communication and negotiation is 3.33. A further comparison shows a significant difference between SUF categories $(H(3)=9.04$, p-value $=0.029)$, defined by the frequency and content of the meetings. With reference to the frequency of meetings, landscape protected areas have a significantly lower level of co-management in comparison to those of national parks $(U=200.50, p$-value $=0.008)$, nature reserves $(U=339.50$, $p$-value $=0)$, and species and/or habitat reserves $(U=59.50$, p-value $=0.038)$. With respect to the content of meetings, national parks have a significant higher level of co-management than species and/or habitat reserves $(U=48.50$ and $p$-value $=0.03)$ and landscape protected areas $(U=187.50$ and $p$-value $=0.004)$. The results therefore show that two-way communication happened more often in national parks, nature reserves, and species and/or habitat reserves than in landscape protected areas. In addition, it appears that more

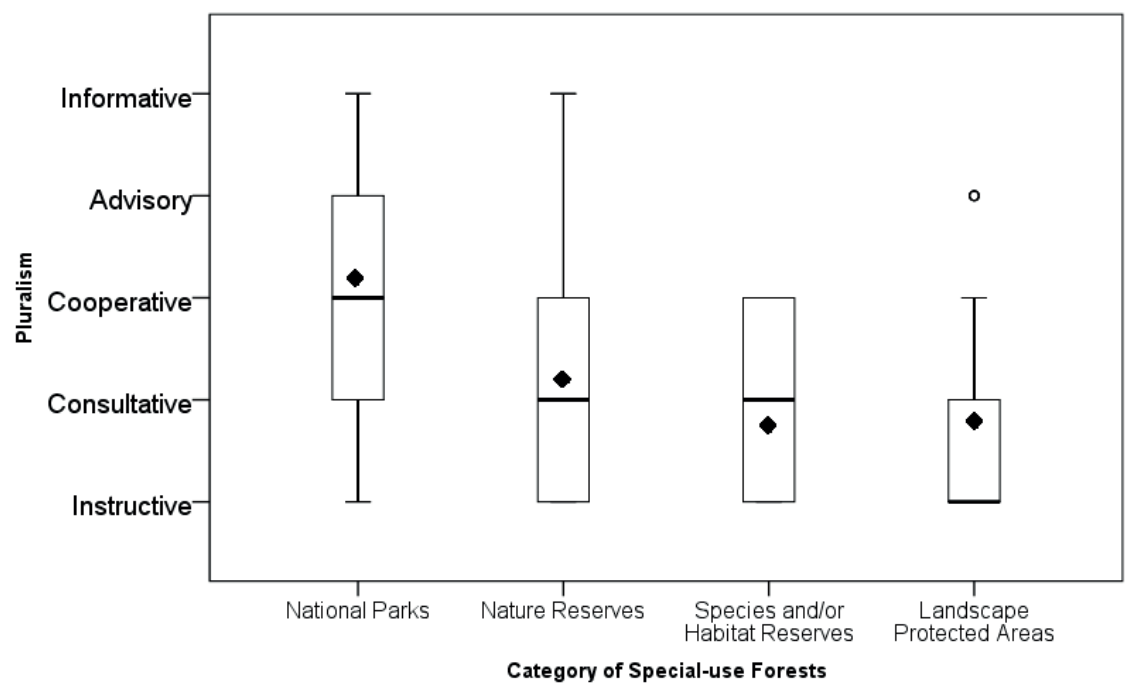

Figure 3.1 A comparison of Pluralism between four categories of SUFs (means; error bars = 95\% $\mathrm{CI}$ ) 
Table 3.3 Percentages of special-use forests (SUFs) having collaborations with different actors

\begin{tabular}{lccccc}
\hline & $\begin{array}{c}\text { National } \\
\text { parks } \\
(n=24)\end{array}$ & $\begin{array}{c}\text { Nature } \\
\text { reserves } \\
(n=45)\end{array}$ & $\begin{array}{c}\text { Species } \\
\text { and/or } \\
\text { habitat } \\
\text { reserves } \\
(n=8)\end{array}$ & $\begin{array}{c}\text { Landscape } \\
\text { protected } \\
\text { areas } \\
(n=28)\end{array}$ & $\begin{array}{c}\text { Overall of } \\
\text { SUFs } \\
(n=105)\end{array}$ \\
\hline Local People & 100 & 94 & 88 & 97 & 96 \\
Private economic sector & 26 & 19 & 0 & 19 & 21 \\
State economic sector & 20 & 22 & 0 & 6 & 25 \\
International & 68 & 21 & 27 & 9 & 24 \\
organizations & 64 & 25 & 12 & 9 & 28 \\
Institute and University & 40 & 27 & 12 & 37 & 32 \\
Civil organizations & 72 & 37 & 12 & 50 & 47 \\
Military & 80 & 48 & 12 & 53 & 54 \\
Police & & & & & \\
\hline
\end{tabular}

diversified communications take place in national parks, with responses ranging from oneway forms of communication such as the delivery of government information briefs of new policies, to more interactive communications such as ongoing consultation of stakeholders to solve conflicts and making important decisions.

While two-way and diversified forms of communication and information exchange were apparent among the main actors, practices are quite different from ideal-typical comanagement arrangements. Two-way communication between the government and park management boards is mainly comprised of PPCs announcing decrees, decisions and guidelines to management boards, and management boards reporting general statistics, as well as constraints to implementation and new activity proposals, in return. Perhaps indicating frustration with this 'bilateral' mode of working, $92 \%$ of respondents emphasized their desire for cooperation with other sectors in managing their areas - but emphasizing their orientation to the PPCs, many stated they would only do so once governmental guidelines had been issued.

When communication with other stakeholders occurred managers reported that it was more interactive than their communication with higher levels of government. They also employ a variety of methods for communication with other stakeholders, including meetings, conferences, quarterly and monthly reports, site visits, and telephone calls. Almost half (46\%) of the SUFs had more than 12 meetings per year, in which stakeholders participated in making proposals, were informed and consulted on new policies, and evaluated co-operation. 


\subsection{Transactive Decision-making}

Overall transactive decision-making in SUFs scored 2.66. No statistically significant differences were evident between the four categories of protected areas. Differences between categories, nevertheless, were found between the two constituting variables. The results show that PPCs are involved in all eight common tasks of co-management, taking a leading role by providing guidelines and making final decisions. This clearly demonstrates that they hold the decisive power in SUF co-management arrangements.

Despite the clear dominance of PPCs in SUF decision-making, the results show that $89 \%$ of SUF managers would prefer further devolution to management boards, arguing that this would improve the effectiveness of area management. National parks had a statistically significantly higher demand for devolution than landscape protected areas $(U=192$, $p$-value $=0.004)$. The results also show a statistical difference between the categories of SUFs in terms of their ability to make independent decisions on solutions to operational or day to day management issues $(H(3)=8.59$, p-value $=0.035)$. The results show that $36 \%$ of the national parks, $46 \%$ of the nature reserves and $88 \%$ of the species/habitat reserves commonly solve operational challenges by themselves and subsequently report their solutions to higher authorities. Far fewer national parks (28\%) and nature reserves (23\%) discuss solutions to operational issues with other stakeholders, including local people, without the participation of higher level governments. Landscape protected areas were least able to instigate devolved decision making processes.

\subsection{Social-learning}

The average score of 3.52 for the combined social-learning variables was high compared to the other co-management characteristics. Furthermore, no significant differences were found among the four categories of SUFs $(H(3)=2.31$, $p$-value $=0.5)$.

The results show that $72 \%$ of the respondents document experiences from management collaboration. However, reactions of higher authorities to the requests of management boards for policy modifications are relatively low. Only 30\% of managers report that modifications on the policies are made by authorities in response to their requests. Less than half $(43 \%)$ of the managers indicated that these more immediate authorities would report the issue to their superiors for advice or support, while a quarter of the mangers responded that their immediate authorities would guide them to provide more detail but would not change the policy. Only 3\% asserted that authorities would not respond to them at all. Half of the respondents argued that requests made by management boards come in less than three months, with $25 \%$ stating that a response comes between 3 to 6 months, indicating an adequate speed of response to requests. 
A significant difference was only detected between the four categories of SUFs with respect to the evaluation of policies $(H(3)=20.02$, $p$-value $=0)$. National parks and nature reserves had significantly lower scores than species/habitat reserves and landscape protected areas (see Figure. 3.3). Just less than a third of the areas (31\%) gave a 'neutral' response when considering their capacity for evaluating policy. Through interviews we found that managers do not view policy evaluation as always being useful. Based on their experience, there is a lack of action following any review that finds a policy or activity as inadequate for SUF protection - they added that this was particularly demotivating.

\subsection{Shared Actions or Commitments}

The average score for SUFs based on these characteristics of co-management was 2.79. A significant difference between categories of SUFs was found $(H(3)=8.09$, p-value $=.044$ ), which is attributed to the recognition of local people's rights. Against this variable national parks scored significantly lower than landscape protected areas $(U=184, p=.004$; see Figure. 3.4). No statistically significant differences between categories of Vietnamese SUFs were found with respect to the other four variables.

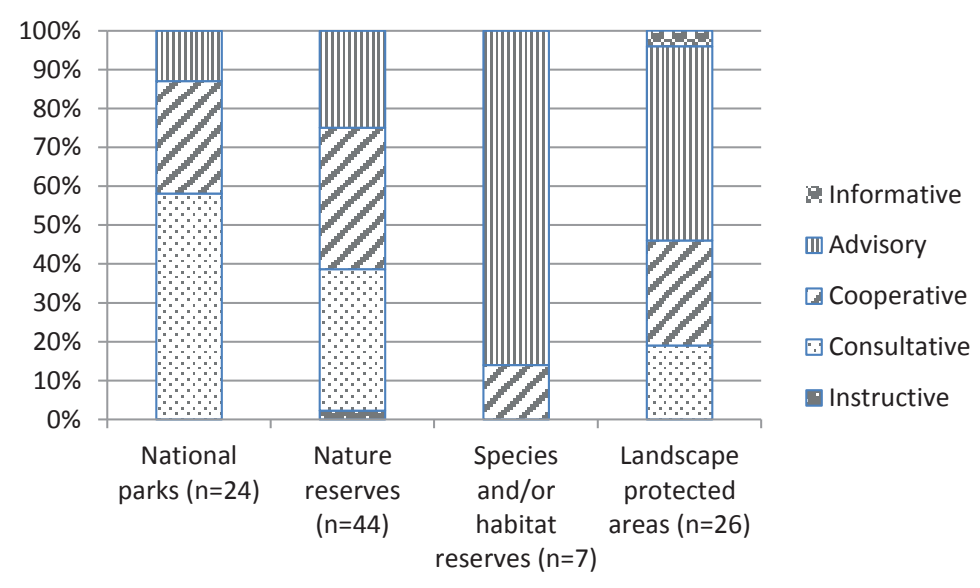

Figure 3.2. Percentage of SUFs that experience evaluation of policy applicability to their site $(n=101)$ 


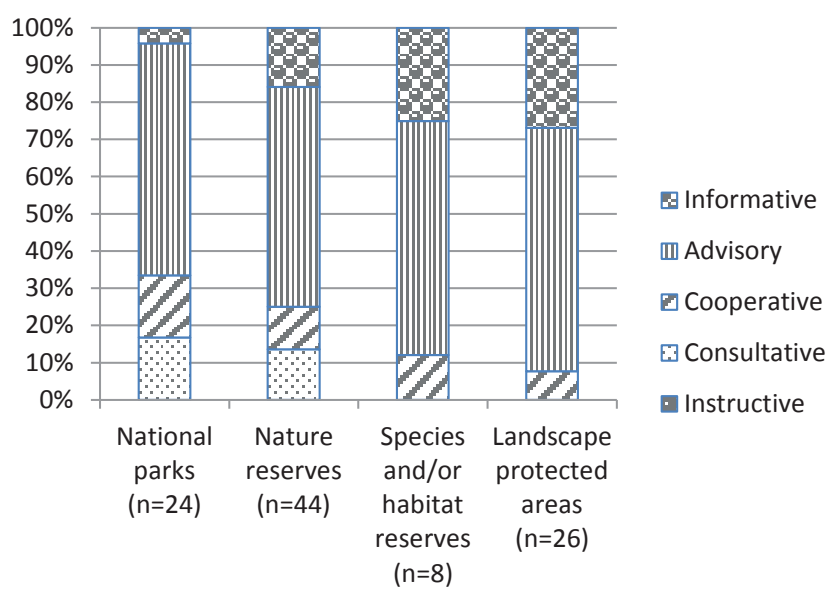

Figure 3.3. Percentage of SUFs that recognize the rights of local people to benefit from the areas $(n=102)$

About $40 \%$ of respondents asserted that efficiencies were created with increasing collaboration, while about 33\% believed there was no change. This ratio was also reflected in results for the question on the recognition of historical values and indigenous customs, where $37 \%$ of respondents agree that the government policy recognizes the values and customs of indigenous people while $40 \%$ do not agree with this proposition. The vast majority of managers $(88 \%)$ indicate there is a lack of incentive-based policies to motivate stakeholders to collaborate with protected areas.

The survey also found that local people were hardly involved in policy formulation around SUFs; if they carry out tasks, it is often in the form of manual labor. The results reveal that the involvement of local people often took place either through contracted tasks such as forest patrol and forest plantation (Figure. 3.5), or in awareness raising activities. Overall, however, local people have very limited rights to exploit natural resources in SUFs. The results show that in only 26 SUFs local people were legally engaged in harvesting nontimber forest products such as honey, forest fruits, and bamboo shoots. In our interviews we found that local people were still primarily considered a threat to natural resource protection, rather than a collaborator in natural resource management. 


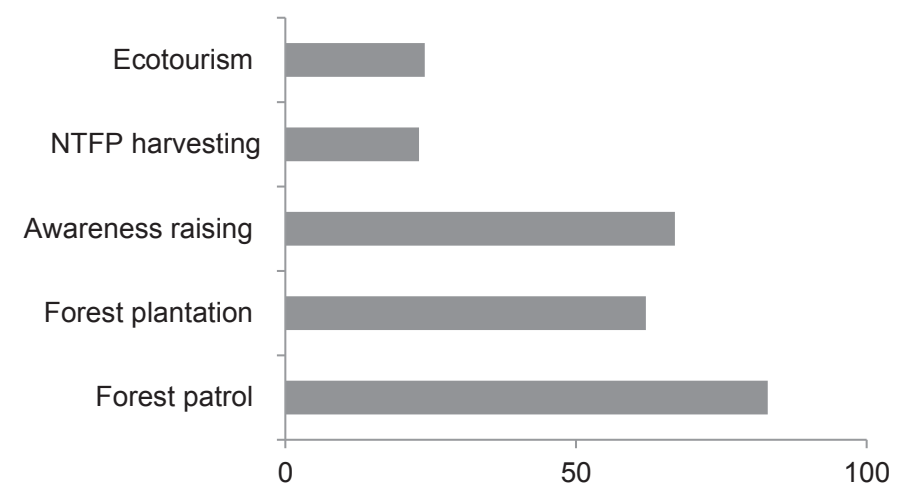

Figure 3.4 Collaboration between SUF management boards and local people (in $\% ; n=113$ )

\section{Discussion}

The results of this study show little diversity in co-management arrangements between the four categories of SUFs of Vietnam. Some varieties exist along the five dimensions of comanagement, ranging from consultative to approximately advisory levels of comanagement, as indicated in Figure. 3.5. There is, however, one notable exception. National parks show a much larger degree of pluralism, and therefore co-management, than the other three SUFs. Three reasons explain the high score for national parks. First, national parks are more likely to engage with international organizations, with projects on livelihood development, awareness raising, environmental education, capacity enhancement, and biodiversity research. In addition, national parks often cover a larger area than the other protected areas, requiring more involvement of the military, police and local people. Finally, research institutes and universities were more interested in doing research on wildlife and biodiversity in national parks than in any of the other categories.

While also having higher scores in communication and negotiation, national parks has the lowest scores in shared actions or commitments. This result reveals that pluralism supports interactions among stakeholders, but collective actions in SUFs management are constrained by legal issues pertaining to cost-benefit sharing mechanisms, allocating harvesting and resource use rights to local and indigenous people, and economically incentive policies (e.g. To, Dressler et al., 2012; Sikor and Nguyen, 2007; BorriniFeyerabend, Pimbert et al., 2004). According to theoretical perspectives of co-management, such a situation of unequal power distributions among actors cause problematic 
interactions that have a high chance of leading to conflicts, especially when local and indigenous people are involved. Sikor and Nguyen (2007), for example, demonstrate that the allocation of forest land previously under shared access regimes often undermines traditional institutional structures and denies access to less powerful groups. Furthermore, they show that the overlap of formal forestland and informal customary rights restricts access and leads to unequal allocation of social and economic benefits, which in turn undermines local livelihoods. Reflecting a prescriptive mode of management, such top down control of pluralism, and the relegation of local people to targets rather than partners in regulation (also seen in other resource sectors of Vietnam, see (Ha and Bush, 2010), remains problematic for state-led co-management of SUFs.

Despite overall scoring 3.06, it is not possible to conclude that Vietnamese co-management arrangements in SUFs can be defined as 'cooperative'. Although co-management in Vietnamese SUFs engages a diversity of actors from different levels and sectors, provincial government organizations (most notably PPCs) still hold most powers of decision-making relating to SUF management. Furthermore, despite being involved in the management of almost all SUF categories, local people are largely relegated to assisting state authorities in patrolling the forests, or as the recipients of awareness raising projects. They are far from equal partners in management, and remain considered a threat to conservation. Local people also have limited possibilities to use and profit from SUF resources. Some protection tasks are delegated to them, including coopting them into a wider management

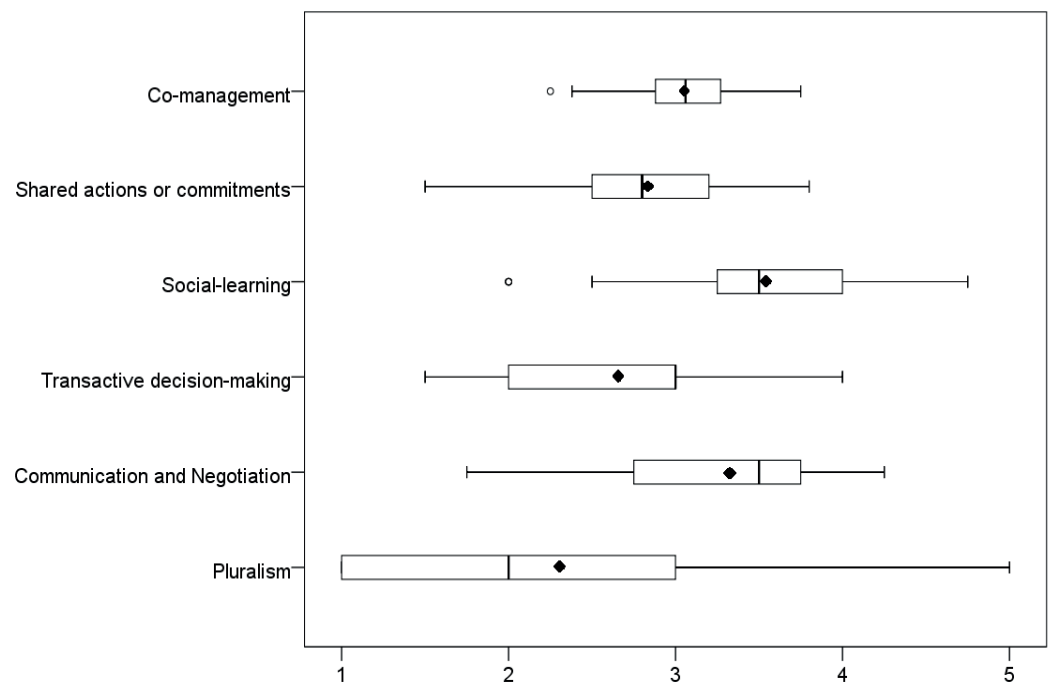

Figure 3.5. Average scores of co-management arrangements along five dimensions (means; error bars: $95 \% \mathrm{CI}$ ) 
framework of wage labour for patrolling these areas, but rights to benefit from the areas are limited. And, perhaps more tellingly, property rights of natural resources in Vietnamese SUFs remain in the hands of the state. Supporting the findings of To et al. (2012), our results indicate that as long as state institutions guide the definition of resource access, that marginalise and in some cases undermine local resource access and use, the utility of collaborative management will remain limited.

Given a closer look at the advanced dimensions of the arrangement, SUF co-management still demonstrates some fundamental contradictions to the essential ideal of comanagement, which emphasizes partnerships between government agencies, local communities and resource users, non-governmental organizations and other stakeholders, in order to negotiate, agree upon, guarantee and implement a fair share of management functions, benefits and responsibility for the management of resources (BorriniFeyerabend, Pimbert et al., 2004). Revisions to SUF policy, following a process of negotiation and/or learning through SUF co-management, has hardly occurred. Further attention is therefore needed to determine what potential negotiation and communication between SUF actors has in building mutual commitments, as well as the extent to which governmental actors are committed to learning from their experiences - including opening up opportunities for different interests and actors to be integrated in management. Further research should therefore focus on the extent to which the government can foster positive changes and adapt to changing management contexts on the ground. Making these processes more transparent may then contribute to upgrading SUF management in Vietnam.

\section{Conclusion: administrative co-management}

While co-management arrangements in Vietnam reflect to some extent the characteristics of 'cooperative' co-management as defined by Sen and Nielsen (1996), the essence and specificity of Vietnamese co-management in SUFs is not captured by this categorization. We suggest that SUF co-management in Vietnam is instead better characterized as 'administrative'; wherein the government (and especially PPCs) remains in control, and management tasks are only partially devolved to either management board or more local levels. Supporting the conclusions of other studies, local people cannot then be considered resource users, but rather perceived as threats to the conservation of forest resources. This is reiterated by the fact that the only stakeholders that are able to be involved in natural resources management are those that are closely linked to the state, such as the military and the police. 
Vietnam and surrounding Southeast and East Asian economies have experienced significant changes and market oriented reforms, including the partial liberalization of environmental management. However, the results of this paper do not reflect this wider trend. Instead comanagement of Vietnamese SUFs do not weaken the dominant position of state power in the control of land and forest resources. Looking forward, is there any chance that comanagement can foster not only administrative but also democratic decentralization or devolution and collaboration in conservation management? Reflecting the change in the region's economies, how 'transitional' then is administrative co-management? Much could be learnt through comparisons with the surrounding transitional countries, including Vietnam's immediate neighbours China and Laos, focusing on the structural barriers to devolving power and control in SUF conservation. In addition, case-study based research would help elucidate the domestic conditions for creating change to more collaborative forms of co-management. 


\section{Chapter 4}

\section{THE VIETNAMESE STATE AND ADMINISTRATIVE CO-MANAGEMENT OF NATURE RESERVES ${ }^{5}$}

\section{Introduction}

Special-use forests (SUFs) are natural protected areas established to conserve the nature and biodiversity of Vietnam. Although the number of SUFs in Vietnam has increased over the years, biodiversity and forest density continues to decline(To Xuan Phuc, 2009, UNDP and Government of Vietnam and GEF, 2010). The Special-Use Forest system of protected area management has been implemented in accordance with ideas of wilderness areas and no-use regimes (Hong and Cach, 2007; Larsen, 2008; To Xuan Phuc, 2009) and strongly relies on the capacity of state agencies, forest rangers, the military, and police. The statebased preservation of natural resources and biodiversity in SUF areas has been variously evaluated as deficient in a number of areas, including managing conflict between multiple user groups (Rugendyke and Son, 2005; Sikor and Nguyen, 2007; Larsen, 2008; To Xuan Phuc, 2009). To overcome these deficiencies, Vietnam has piloted co-management approaches in many SUFs since 2001, and as of 2003 included co-management in its official national strategy for SUF management (Sandbrook, Trong et al., 2010; Swan 2010).

Unlike other countries in Southeast Asia (e.g. (e.g. Evans, Cherrett et al., 2011; Ratner, Oh et al., 2012), direct collective action and self-representation outside mass-organization groups or people's committees is not politically feasible in Vietnam(e.g. Sikor and Nguyen, 2007; Coe, 2012). So, while numerous actors are involved in co-managing SUFs in Vietnam, the state administration hold most allocative decision-making power relating to SUF management and constrains the capacity of management boards to fulfil their mandated functions of conservation, research, and coordinating the maintenance of ecosystem services. As argued by KimDung et al. (KimDung, Bush et al., 2013), Vietnamese implementation of co-management in SUFs is, therefore, best defined as "administrative"; reflecting the stronger role of the central state, and their collaboration with governmentsponsored agencies that "represent" communities and facilitate their involvement. However, the state is far from monolithic in this administrative role. As outlined by Ratner et al. (Ratner, Oh et al. 2012), state actors are internally differentiated, and enable to

\footnotetext{
5 This chapter has been published as KimDung, N., Bush, S., \& Mol, A.P.J. (2016). The Vietnamese State and Administrative Co-management of Nature Reserves. Sustainability, 8, 292.
} 
constrain one another in a variety of ways, which ultimately affects how the state performs cooperative forms of natural resource management.

This paper explores how, in spite of the constraints presented by an administrative form of co-management, state entities such as SUF management boards attempt to fulfil their mandate and collaborate with local communities. Based on in-depth case-study research we explore the internal dynamics within the Vietnamese SUF system, examining how the relative role and influence of vertically-related state agencies connect to the management boards of Special-Use Forests and horizontal networks of non-state actors in the development of collaborative SUF management. Building on Ratner et al. (Ratner, Oh et al., 2012), we adopt a critical institutional perspective to co-management, thereby extending the existing co-management literature in Vietnam and beyond, to focus on the internal dynamics of state interaction, the effect on community cooperation, and the impact on natural resource management.

The following section introduces our critical institutional perspective used to analyze our case studies and reflects on the role of state and non-state actors in administrative forms of co-management. We then present the results of the national SUFs survey before presenting the four case studies. The national survey serves as an exploration of the strategic interactions within the Vietnamese SUF governance system, while the four case studies help diagnose how different co-management arrangements perform (comparatively) when confronted with similar environmental challenges (see Schlager and Ostrom, 1992). Sections Four and Five then analyze the role of different state actors in implementing administrative management arrangements and the extent to which they facilitate collaborative decision-making processes in SUFs in terms of the capabilities and responsibilities of governmental organizations.

\section{A critical Institutional Perspective of Co-Management}

Co-management is fundamentally about the multiple linkages, power relations, and social relationships between actors that enable problem solving (linking to wider notions of adaptive learning and flexible decision-making) for natural resource management (Plummer and FitzGibbon, 2004a; Armitage, Berkes et al., 2010; Ostrom and Cox, 2010). This distinguishes co-management from state centric forms of resource management by emphasizing the interdependencies between public and private actors at different levels and scales, and the degree of cooperation in practical real-life arrangements to solve these problems (Adger, Brown et al., 2005; Carlsson and Berkes, 2005; Berkes, 2010; Marín and Berkes, 2010; Ratner, Oh et al., 2012). Given the complexity of these interdependencies, co-management is increasingly conceptualized as a "governance network" with varying 
interactions among the state, communities, NGOs, international organizations, and other public and private interests(Carlsson and Berkes, 2005; Finkbeiner and Basurto, 2015). The notion of a network implies a degree of decentralization and democratization in problem solving - more so, it is thought, than uni-dimensional co-management typologies (e.g. Sen and Nielsen, 1996; Plummer 2009). However, returning to KimDung et al. (KimDung, Bush et al., 2013), when these co-management networks are controlled by a centralized state questions emerge about the extent to which effective problem solving can be achieved.

In addressing such questions, social science research on co-management has shifted from more proximate issues related to establishing co-management, including capacity-building and regulatory change, to what Ratner et al. (Ratner, Oh et al., 2012) have labeled a second generation of questions focused on the conditions and politics that facilitate the formation of co-management arrangements. In response to a growing critical literature related to comanagement in Southeast Asia (Pomeroy and Rivera-Guieb, 2006; Pomeroy, Nguyen et al., 2009; Oh 2010). Ratner et al. (Ratner, Oh et al., 2012) argue that questions related to the institutional design of co-management need to focus on politics and changing power relations, resource competition across sectors and scales, the capacity of institutions to promote adaptive learning and reconcile multiple values and goals. Taking these questions into account we are able to focus specifically on what Vatn (2005) refers to as the "normative" aspects of natural resource institutions, including the political and social context within which co-management is constructed.

We build on Ratner et al. "second generation" perspective by introducing what we call a critical institutional perspective to co-management. By applying this critical approach we analyze how administrative co-management is constructed as well as how its deficiencies might be overcome. We do this by looking at administrative co-management as a networked form of co-management, and in doing so analyze the type of collaboration between multiple public and private organizations and the central state. From this critical perspective we see co-management networks as constructed (and contested) through processes of competition and learning, and embody divergent interests, values, and goals of their constituent public and private actors. The type of collaboration between these actors is then determined by the relative power and allocative authority of each actor, which regulates strategic interactions between actors, the distribution of resources, and the degree of deliberation over (conservation) rules (Sandström and Rova, 2010). By focusing on the purpose, interests, and resources of actors, and their effect on the actions, performance, and collaboration, we can critically analyze how co-management networks form. Consequently, we can also observe and analyze how they create inter-dependencies 
between actors that represent the power relations that underlie administrative comanagement embedded within the political and social context of Vietnam.

In developing a network approach for understanding the norms, rules and relationships that make up co-management arrangements we adopt a sociological understanding of institutions - in contrast with the bounded rationality of, for example, Ostrom's Institutional Analysis and Development Framework (Ostrom, 2009). In doing so, based on Plummer and FitzGibbon (Plummer and FitzGibbon, 2006) and others (Hahn, Olsson et al., 2006; Armitage, Plummer et al., 2009; Armitage, Berkes et al., 2011; Marín, Gelcich et al., 2012), we define constituent sets of vertical and horizontal linkages in co-management networks that identify linked but separate sets of actors and institutions, how and where these intersect, and what effect they have on the distribution of control and distribution of resources.

Vertical linkages relate to relationships between (more) central state agencies and authorities and place-based natural resource users/managers. Such linkages are vertical in that they refer to more directive modes of policy and control - reflecting the one party, centrallyplanned political system of Vietnam, but also natural resource and conservation regimes in other countries in Southeast Asia and beyond (Cinner, Daw et al., 2012, Ribot and Larson, 2013). Authority in these vertical linkages is most directly related to state policy and legislation, supported by judicial enforcement (Wallace, 2009; Clement, 2010). The often cited challenge for the state actors (departments and agencies) involved in this vertical dimension is to establish systems of control that are able to adapt to the deficiencies of state bureaucracy while maintaining the capacity to co-condition and "steer" on-site comanagement strategies and outcomes (Berkes, 2009; Clement, 2010; Ratner, Oh et al., 2012). Drawing on the wider co-management literature (Sen and Nielsen 1996), these vertical linkages structure the capability of resource users to contribute to the formulation of rules and management arrangements.

Horizontal linkages refer to the collaboration and interactions of different - state, non-state and hybrid - actors at the site of natural resource management. They differ to vertical linkages in that the actors involved are not steered directly by the central state, but instead seek varying kinds of partnerships with actors with similar norms, levels of civic engagement and rule setting capabilities (Plummer and FitzGibbon, 2006; Marín, Gelcich et al.; 2012). Membership to these horizontal networks is also (more) voluntary and decisions are commonly regarded as (more) deliberative than vertical linkages steered by the state, and are (better) able to deal with locally specific conflicts (Plummer and FitzGibbon, 2006; Olsson, Folke et al., 2007). Horizontal interactions expose the ways in which "second generation" co-management functions - moving beyond a single sector. At the center of these two networks is often a formalized management organization that coordinates the actors involved and provides an institutional bridge between state law and community-level 
rules over resource access and use (Hahn, Olsson et al., 2006; Olsson, Folke et al., 2007). In the centralized SUF system of Vietnam this is the so called "management board".

Co-management networks, made up these two separate but interrelated parts, therefore, help to identify sites within which we can understand the relational dynamics of resource control that often occur far from, but still subject to state power (Clement, 2010). In the case of the Vietnamese SUF system, the form and function of co-management remains contested, with different expectations and goals of actors within both vertical and horizontal networks. However, despite this contestation, administrative control remains with the state, and operationalized through SUF management boards. The tensions between horizontal and vertical networks is then central to understanding: (1) how decentralized and devolved responsibilities to lower levels of government (commune, district, provincial) are put in place; and (2) the extent to which horizontal actors are included in decision making, including their interdependencies and interactions with SUF management boards.

\section{Methodology}

In order to understand strategic interactions of actors in vertical and horizontal networks a two-tiered methodology was adopted for this research. The first tier is at the national level to observe patterns of SUF co-management across at the national level. The second tier focuses on contrasting case studies, designed to draw out diverse local contexts and conditions while allowing for comparison (Yin, 2013). We divide the research into these two tiers in order to draw out patterns which can be generalized by reflecting on their relevance and similarity to the theoretically abstracted notions of co-management networks.

Primary data was collected from four rounds field research. First, a nation-wide survey on the role and collaboration of management boards of 113 of the 161 Vietnamese SUFs (see KimDung, Bush et al., 2013). A subset of data were used for our analysis, focused on constraints, and expectations of SUF management to fulfil a cooperative function in their management of SUFs. Second, in-depth interviews were completed with 22 randomlyselected SUF management board members to clarify how management boards cooperate with other state actors. Third, after reflecting on the national survey data, in-depth case study analysis was conducted in four SUFs, represent different categories of SUF: Nui Chua national park (Ninh Thuan province), Khau Ca species and habitat reserve (Ha Giang province), Cu Lao Cham landscape protected area (Quang Nam province), and Xuan Thuy national park (Nam Dinh province). Data for these cases was collected through interviews with the Provincial People's Committees (PPCs), District People's Committees (DPCs), 
Commune People Committees (CPCs), international non-government organizations (NGOs), and local resource users. Fourth, secondary data was collected from national and local governmental documents to supplement empirical field results.

\section{SUFs Administrative Co-Management Arrangements}

\subsection{Emergence of Co-Management in Vietnam}

From 1962 to 1986, forest conservation in Vietnam was based on a system of "prohibited forests", comprised of 87 areas classified as national parks, nature reserves, and cultural, historical, and environmental areas (Vu Van Dung, 2002). As part of the wider politicaleconomic reforms (Doi mor) at the end of 1986, the Vietnam's Ministry of Forestry decreed the reclassification of these lands into "special-use forests", defined as national forests established to protect and conserve forest habitats, flora and fauna genes, landscapes, and cultural and historic values, and to facilitate scientific research and education (Vietnam Government, 1986). After a further round of reforms in 2010, 161 SUFs were established (covering 2,198,744 ha), classified as national parks (30), nature reserves (55), species and habitat reserves (11), and landscape protected areas (45), and experimental research forests (20) (which are excluded in our research due not to exist in the classification of the Vietnam Biodiversity Law - see KimDung, Bush et al., 2013 for further detail). According to Sam and Trung (2001), government policy have shifted the sector from being reliant on central planning and subsidies to engaging multiple non-state actors (Sam and Trung, 2001) and covering a diverse range of issues such as investment, research, protection, enrichment, and management. More recent attention has been given to policies encouraging grass-roots participation in the highly contentious processes of land and concession allocation(Tan, Chinh et al., 2008).

The term "special use" was a deliberate attempt to distinguish tenure arrangements based on varying access arrangements to state owned land. More specifically, "special use" distinguishes these areas from protected forest, largely used in watershed protection, and household level production arrangements under either "red book" 50 year transferrable leases or "green book" 20 year leases with specified conservation easements (see Sikor, 2001; Jong, Do et al., 2006). The specification of clear tenure arrangements in and around SUFs remains an important issue given that $80 \%$ are estimated to be inhabited (PARC Project, 2006, Cuong, Dung et al., 2009), and 30\% have to deal with historical conflicts over land rights (Nguyen Hai Van, 2014). Benefit-sharing mechanisms have been put in place to mitigate the effects of acute conflicts, such as encroachment in poorly defined buffer zone areas (e.g. PARC Project, 2006; McElwee, 2010). Overall, however, SUFs are governed as state property aimed at maintaining ecosystem functions, biodiversity, 
historical, and cultural landscapes, and resources for scientific research (Vietnam Government, 2010; Government, 2013; Vietnam Government, 2014).

To engage local stakeholders in and around SUFs the Vietnamese government shifted to their own form of "collaborative approaches" under the premise of protected area management and improve the protection of forest habitat and biodiversity (Boissiere, Sheil et al., 2009). This shift towards co-management within SUFs was formalized by the 2003 Management Strategy for Protected Area System and the 2004 Land Law set legal rights and responsibilities of local resource user involvement, and subsequently strengthened by the governments obligations under the Convention on Biological Diversity Program of Work on Protected Areas (IUCN, 2006), a number of foreign-funded pilot SUF comanagement projects (Andrew and Quan, 2007; Sandbrook, Trong et al., 2010), and reforms to the policies related to state management and local authority capacity (Vietnam Government, 2003). Vietnamese collaborative management has, therefore, emerged as an administratively decentralized but centrally-controlled form of management, rather than based on collection action.

\subsection{Vertical Collaboration}

The overall responsibility for SUFs lies with MARD, who regulates almost all aspects of SUF management at both national and local levels (through Decree 117/2010/ND-CP). MARD plays a direct role in the administration of six national parks of special importance or inter-provincial transboundary parks. Within MARD, the Forest Protection Department (FPD) plays a key role in monitoring and managing the SUF network (Government of Vietnam 2003, PARC Project, 2006). The management of other protected areas is shared between MARD, who takes administrative control, and more specialist Ministries related to the resource at hand. For example, wetland conservation and protection and land use management is in partnership with the Ministry of Natural Resource and Environment (MONRE), and marine conservation (also incorporated into the SUF system) is shared with MARD (PARC Project, 2006).

Implementation and administration of the SUFs comes under the direct responsibility of the People's Committee at both provincial and district levels. The Provincial People's Committees (PPCs) either take direct control or delegates to the provincial or district Departments of Agriculture and Rural Development (DARD), depending on the scale and complexity of the management task (Vietnam Government, 2001). In the case of national parks, which have a higher status than the other SUFs, management boards responsible for day-to-day operations report directly to PPCs (Swan, 2010). These management boards are made up of officials appointed by the provincial DARDs (ICEM, 2003). Where management boards have not been established, the line of responsibility is less systematic; 
with a variety of government departments responsible for operational decisions, such as the District FPDs, Provincial Departments of Agriculture and Rural Development, or Provincial Departments of Culture, Sport, and Tourism.

The state has the legal responsibility to provide management boards with the necessary institutional conditions to fulfill three key functions (Vietnam Government, 2010). First, they have to protect, conserve, and develop the natural value of forests, conserve bio- and genetic diversity, and preserve historical and cultural landscape values. Second, they have to coordinate scientific research, and third, provide environmental services relating to the SUFs, such as ecotourism, services of land protection, water provision, carbon absorption and storage, greenhouse gas emission reduction. However, the effectiveness of SUFs to fulfil these functions, set out by the administrative branch of the government, is strongly dependent on their relationship with the political branch, represented by the PPCs and CPCs. This central importance of PPCs was clearly perceived by the management boards interviewed. SUF managers emphasized the power and authority of PPC within a provincial boundary and prioritize stronger collaboration with them (Figure 4.1). The majority of managers also want improved collaboration with CPCs, which engage local people through civil organizations, such as Women Union and Youth Union. In doing so they hope to offer alternative livelihood strategies to local people involved in nature conservation projects. However, CPCs are also not assigned any state budget for nature conservation, nor for collaboration with SUF management boards. This places management boards in a precarious position; on the one hand seeking permissions and resources from the more powerful PPCs (also see in PARC Project, 2004) while channeling these funds to CPCs in the form of livelihood improvement and awareness raising projects.

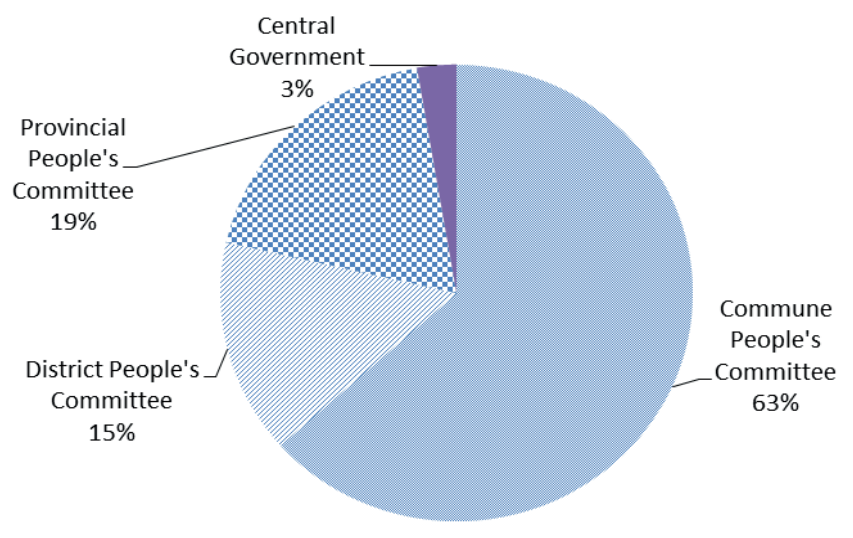

Figure 4.1. Priority of SUF management boards in furthering governmental cooperation ( $n$ $=112$ ). 


\subsection{Horizontal Collaboration}

With their limited resources SUF management boards are strongly dependent on a range of horizontal collaborations with groups outside the immediate government hierarchy within which SUFs are located. These include the military and police, international organizations, universities/institutes, companies, and local communities. Over time these groups have become centrally important to fulfil the legislated requirements of conservation, conducting research, and coordinating ecosystem services.

Conservation is interpreted by most management boards interviewed in terms of patrolling and policing of land encroachment, illegal forestry, and wildlife poaching. Two key public partners who provide enforcement capacity in support of the forest rangers in protected areas and buffer zones are the police and military. However, despite the perceived importance of this collaboration, the services of both the police and military are gradually becoming formalized and monetized and, albeit indirectly, controlled by the PPC through their budget oversight (Table 4.1). Budgets for planned cooperation, such as petrol for patrolling marine and land areas, are in place, unscheduled support to rangers in patrolling the area are not budgeted. As a consequence, collaboration is limited to monitoring past violations rather than proactive policing and enforcement.

Table 4.1. Current and priority for future horizontal collaboration of SUF management boards.

\begin{tabular}{clcc}
\hline No. & Actors in horizontal networks & $\begin{array}{c}\text { Current collaboration } \\
(\boldsymbol{n}=113)\end{array}$ & $\begin{array}{c}\text { Priority for further future } \\
\text { collaboration }(\boldsymbol{n}=\mathbf{1 1 3})\end{array}$ \\
\hline 1 & Local people & $96 \%$ & $71 \%$ \\
2 & International organizations & $34 \%$ & $11 \%$ \\
3 & Research and education institutes & $28 \%$ & $8 \%$ \\
4 & Police & $54 \%$ & $4 \%$ \\
5 & Military & $47 \%$ & $1 \%$ \\
6 & Civil organizations & $32 \%$ & $1 \%$ \\
7 & Private companies & $21 \%$ & $1 \%$ \\
8 & State-owner companies & $15 \%$ & $1 \%$ \\
\hline
\end{tabular}

Research coordination is conducted in collaboration with more than 23 international organizations working SUF management boards across a range of broadly related activities such as awareness raising, capacity building, environmental education, and nature conservation research. International organizations such as IUCN and WWF focus collaboration on national parks and nature reserves. However, $66 \%(n=113$; Table 4.1) of the SUFs reported that they had no international cooperation, and few management boards $(11 \% ; n=113)$ give high priority to more international collaboration. If they do give 
priority it is especially to overcome budget and staff capacity constraints in implementing nature conservation and research. Similarly, management boards also wish to strengthen collaboration with domestic scientific institutes in order to apply for national and international research funding.

Around one third of the management boards surveyed engage with businesses, often in relation to eco-tourism. It is unclear rules for benefit sharing, responsibilities and commitments also lead to conflict, and management boards are not eager to extend these collaborations (Table 4.1). Many management boards complain that tourist activities threaten SUFs through environmental pollution, forest fires, and road and resort constructions. Companies often refuse to pay for the environmental services they profit from and hardly contribute financially to SUF management, creating tensions between management boards and tourist enterprises. The tourist enterprises usually have close relations with PPCs and obtain PPC licenses for tourist business, making it extremely difficult for management boards to refuse ecotourism activities in their SUFs.

Community partnerships have been strongly influenced by the continued perception that communities surrounding SUFs are unlikely to be effective conservation partners. Nearly three quarters of SUFs managers held this position. The dominant partnership with communities is through direct employment as forest patrols (83\% of SUFs, $n=113)$ and in wider information dissemination activities ( $62 \%$ of SUFs). Slightly less than one quarter of all SUFs develop partnerships or provide support for harvesting non-timber forest products (23\% of SUFs) (see also Corbett 2008), largely because of central government control over access to key natural resources. Instead, livelihood activities that focus on "resource substitution" are more common, such as providing loans for livestock to protected areas-affected populations and livelihood allocation.

For all three key functions that management boards have to fulfil it is ultimately the PPCs that manage their staff allocation, decide their operational budgets and hand out licenses for NGO and private sector collaboration (Figure 4.2). Although some input comes from the Department of Planning and Investment (DOPI) and the Department of Finance (DOF), the horizontal collaborations outlined above strongly influence their management effectiveness, as well as their capacity to develop co-management arrangements with local resource users. The only alternative funding available is through the centrally government's Program 661, a fund providing (albeit very low levels of) compensation to people whose have been heavily affected by exclusion from SUFs (Sikor and Nguyen, 2007; Larsen, 2008; Clement, 2010). According to one SUF manager interviews, that this leaves very few resources to establish meaningful co-management relationships with these communities. 


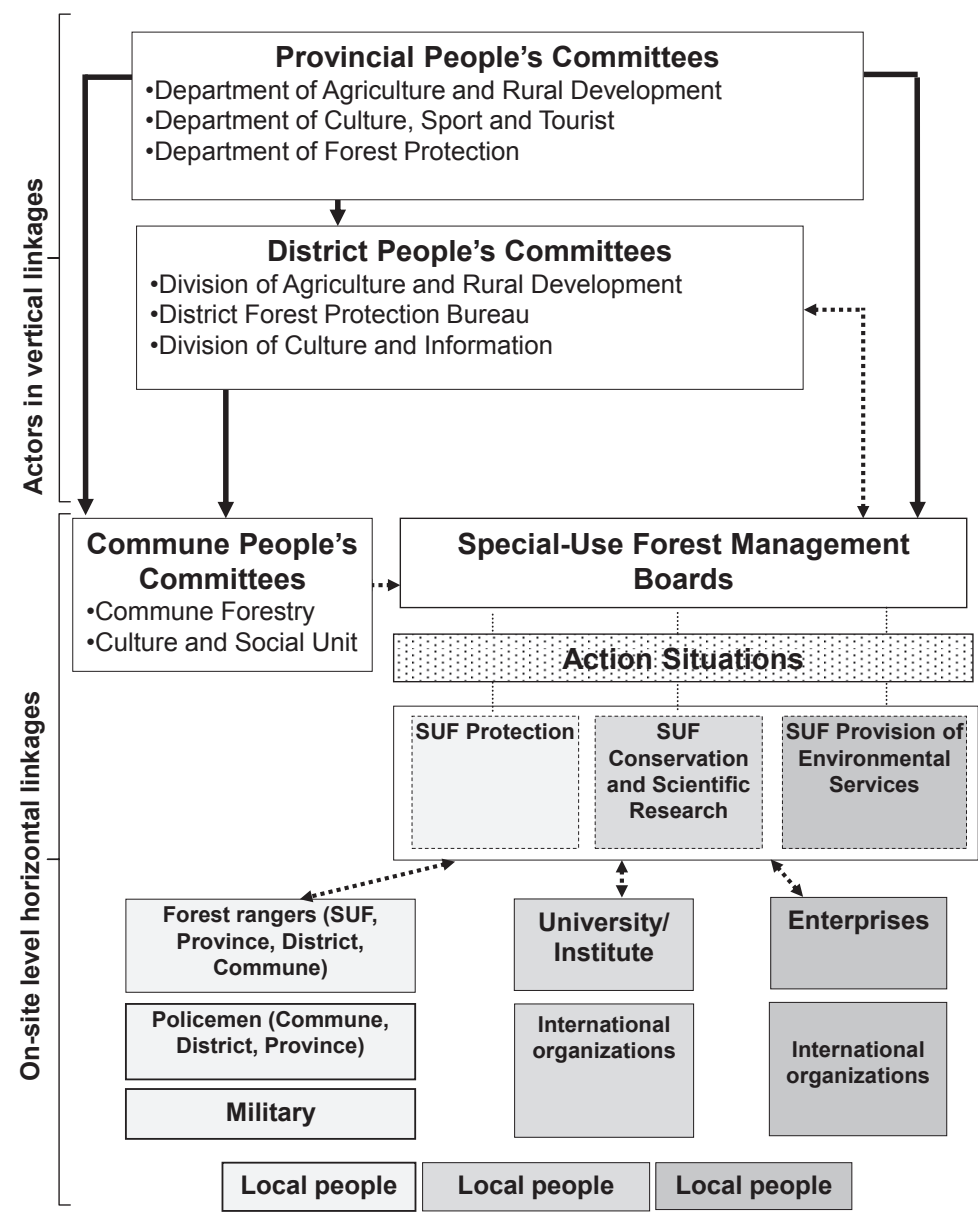

Directive relations

Collaborative relations

Figure 4.2. SUF management board in administrative co-management networks.

Note: directive relations indicate authority of one actor over another. Collaborative relations involve communications and negotiations to gain co-operation. 


\section{Four Cases of Administrative Co-Management Arrangements}

SUF management boards are assigned ambitious functions and tasks, but have limited authority and resources, and are confronted with severe pressure on natural resources. This constitutes a major challenge for co-management of SUFs. In this section, four cases are analyzed to better understand how collaborations between management boards and vertical and horizontally related actors influence their capacity to fulfil their mandated management functions.

\subsection{Cu Lao Cham Landscape Protected Area}

The Cu Lao Cham marine protected area (MPA) is considered a highly collaborative case of SUF management in Vietnam. The park was established in 2006 and recognized as a World Biosphere Reserve in 2009 based on its distinguished values of forest, marine biodiversity, history and culture. The Cu Lao Cham management board falls directly under Quang Nam DARD and is responsible for protecting marine biodiversity, sustainable use of marine ecosystems, and preserving historic-cultural values (in support of the nearby UNESCO city of Hoi An). The MPA is divided into a protection zone and an ecological rehabilitation zone both designed for conservation, and a controlled development zone designed to allow income generating activities, such as ecotourism and fishing.

The $\mathrm{Cu}$ Lao Cham MPA was established in 2000 as part of a donor funded nationwide marine protected area network. MARD (previously the Ministry of Fisheries) was given responsibility to support the MPAs, while the Ministry of Planning and Investment (MOPI), in collaboration with international organizations such as IUCN and WWF, participated in designing the parks management system. The Global Environmental Facility and UNESCO sponsored also funded conservation and tourism planning with local authorities and communities.

Despite the wide network of actors involved in the establishment of the MPA, the Quang Nam PPC maintains authority over all planning and regulation; although regulations relating to local communities requires consultation with local government before being approved by the PPC. The PPC's executive departments (e.g. DARD, DOST, DONRE, and DOCST) cooperate with the management board to implement activities, while the police and military patrol violations. Both the DPC and CPC participate in the design and implementation of community relations the management board puts in place. The Hoi An Town People's Committee (equivalent to a DPC) has supported livelihood programs, and provided budget for solid waste systems and species protection, while the CPC has been active in organizing community level conservation activities.

Community engagement has been firmly state-led, through consultations by the management board around zoning, planning and alternative livelihood activities in the 
MPA. According to the park managers, many local groups have also supported the SUF management board and have actively joined patrols by forest rangers and the military. However, it appears there have been trade-offs to this involvement, with concessions granted for modified, less-exploitative livelihood activities within the park. The board has also worked with scientific institutions and enterprises to offer training courses on nature conservation, as well as skills related to the emerging tourist business, such as English language and business development courses.

Perhaps the most importantly the park has shifted its funding away from a dependency on Danish assistance (lasting from 2006 to 2010) to income generation from tourist fees, service incomes and taxes on joint ventures. All of the funds generated support the Cu Lao Cham management board, two military posts and the Tan Hiep CPC. This means that despite the ongoing control by the PPC the management board has established enough financial independence to allow it to fulfil its statutory functions and actively involve local communities into a well-functioning administrative co-management system.

\subsection{Khau Ca Species and Habitat Reserve}

Khau Ca Species and Habitat Reserve was established in August 2008 by the Ha Giang PPC to protect the critically-endangered Tonkin snub-nosed monkey (Rbinopithecus avunculus), one of the 25 most endangered primates in the world. The decision led to the establishment of the Khau Ca management board by the Provincial Forest Protection Department (PFPD), but because no budget was allocated to the reserve, the board sought funding from domestic and international sponsors. Their success is seen in the reserve's current support base, including Fauna and Flora International (FFI), the San Diego Zoo (USA), the Denver Zoo (USA), and the University of Colorado (Boulder, USA). Both the zoos and FFI provide scientific support; building on FFI's initial discovery of the snubnosed monkey in 2002. In addition, PanNature, a Vietnamese NGO, cooperates with Khau Ca to implement educational programs on monkey conservation in local schools.

Despite the financial independence of Khau $\mathrm{Ca}$, the Ha Giang PPC remains the most influential actor in overall management and is directly involved in facilitating international collaboration for the reserve management board. This is seen as a major advantage to management board staff given the burden of finding and managing these relationships. Since the PPC took direct financial control of international collaboration the provincial Financial Department (one of the executive bodies that falls under the PPC) was excluded from operations at the behest of the management board, believing it would make financial management more complicated. To reduce costs the board streamlined the reserve organization by employing only four staff, including a leader of the PFPD; a move which 
was welcomed by managers given this body is responsible for mobilizing forest rangers from district forest protection units.

The board has not established a close relationship with the DPC because it found it more convenient to work directly with CPCs (with permission from the PPC). Both the DPC and CPC have no budget for nature conservation, but the CPCs are more supportive of activities that directly engage local people. The CPCs provide a platform for conflict resolution and are supportive of alternative livelihood activities. The three surrounding CPCs also nominate ten local people to patrol the forest, provide research support by monitoring the Tonkin snub-nosed monkey, and disseminate information about species conservation in partnership with the Youth Union and Women Union. These rangers in turn report violations to the board, who seek juridical support from the commune police and forestry unit.

In this case, greater collaboration with the CPCs is welcomed, but continues to be limited by the financial control the PPC maintains over the reserve. The central position of the board is supported by their success in attracting funding. But these funds and, hence, the activities of the board, remain under the control of the PPC to a large extent. Comanagement remains administrative in nature, due to control over funding, but the management board has been able to negotiate more direct relations with local communities through their collaboration with international organizations.

\subsection{Nui Chua National Park}

Nui Chua National Park, comprised of an inland area of 22,513 ha and a marine area of 7532 ha, was established in July 2003. Ninh Thuan PPC has devolved administration of the park to the local DARD, which approves all activities and collaborations in the park.

The park is strongly divided on ethnic lines, with the minority Raglay people heavily dependent on the collection of firewood, medicinal plants, and forest fruits, as well as charcoal production and logging (Nui Chua national park 2008). They also (illegally) practice swidden agriculture on the steep sloping areas within the park. The desire of the government to reduce these forest-based practices, coupled with the attention Ninh Thuan receives as one of the poorest provinces in the country, has led to a number of programs on "hunger eradication" and poverty alleviation focused mainly on the Raglay.

A number of international organizations support nature conservation in the park. WWF runs coral reef and sea turtle conservation projects as part of the same Danish project that supported the $\mathrm{Cu}$ Lao Cham MPA. In addition, the Vietnam Conservation Fund (VCF), with funding from GEF-TFF-EU, supports research on biodiversity. With funding from Program 661 VCF has developed community forest protection with two Raglay villages in the park buffer zone paid to undertake forest patrols, and two other communities have 
been paid for sea turtle conservation and coral reef protection, with additional support going to their children to study at Hoa Sua School of Tourism.

The conservation payment model has meant that the control of the Ninh Thuan PPC over nature conservation has been diminished. However, the PPC continues to control all other activities around the park, leaving what might be called a "sectoral divide" within the park. For example, while the PPC is solely responsible for road construction and tourist development, it does so without the participation of those involved in nature conservation, including the management board and the Ninh Hai DPC and CPC. The result has been poor coordination with communities, ongoing land encroachment, and conflicts over benefits and responsibilities between the management board, CPCs, and tourist enterprises.

The Nui Chua management board sees the value of collaborating with the DPC and CPC. However, due to the central position of the PPC, the DPC's involvement has been limited to minor projects, such as organizing clean-ups of hatching sites of turtles involving the Youth Union, military, and other district-level executive agencies. Collaboration with the CPC has been more successful, with the implementation of alternative livelihood projects and participatory models for turtle conservation, coral reef protection, and forest protection. However, in practice, the management board has developed all the plans leaving the CPC to only assist in implementation.

Despite the strong vertical oversight of the park by DARD, the Nui Chua management board has been proactive in searching for funds and widening its horizontal relations. However, these relations, especially with the CPC and international organizations, is fragmented and where they are in place have only led to short-term interventions. Furthermore, the finalization of Program 661 in 2010 ended conservation payments for forest protection. As such, no long term co-management model has been established and the management board remains dependent on the PPC, while still regarding Raglay people as an ongoing threat to, rather than a partner for, conservation.

\subsection{Xuan Thuy National Park}

Xuan Thuy national park was established in January 2003 and is administered by the Nam Dinh DARD (PPC, 2006). In 1988, 15 years prior its establishment, the park became the first Ramsar site of Vietnam, and in October 2004 it was also acknowledged as the core zone of the Red River Delta Biosphere Reserve by UNESCO (Hong and Cach, 2007).

The area is also long-time site of harvesting two clams, Meretrix lusoria and Meretrix lyrata, by local communities. As a Ramsar wetland, these harvesting activities were banned in the core area of the park, but a lucrative market for these species led to illegal exploitation. In 2005, communities protested the illegality of their harvesting activities and the Xuan Thuy 
management board asked for a new resource exploitation plan from the PPC. The PPC considered the case as beyond its authority and advised the management board to bring the issue to the Ministerial level. Two representatives of MARD, one from the Department of Policy and one from the Forestry Protection Department (FPD), visited the site to see the problems first hand, and subsequently asked the management board and PPC to prepare a proposal for conflict resolution. The result was the formulation of a pilot project on the "wise uses of Meretrix lusoria and Meretrix lyrata in core zone of Xuan Thuy National Park".

The project centered on improved collaboration between the management board with the DPC and CPC. Through the project, the Nam Dinh PPC delegated its authority to Giao Thuy DPC to establish a management board for clam exploitation in Red River delta within Xuan Thuy, with representatives from the Giao Thuy DPC; Xuan Thuy management board; executive District departments; local CPCs; military; police; Giao Thuy District Station of Fishery Inspection; and the Forest Protection Division of Xuan Thuy. The Giao Thuy DPC ordered district agencies under its administration to collaborate with the Xuan Thuy management board to plan conservation and management activities. In addition, the plan placed emphasis on local representation, with organized groups of clam pickers also sitting on the management board.

The plan stipulated that the Nam Dinh PPC is responsible for issuing regulation and monitoring project implementation. The DPC is in charge of ensuring proper project implementation on-site, in accordance with the provincial regulations and assist CPCs in planning, land allocation, monitoring, enforcement, and conflict resolution in the designated exploitation zones. Clam pickers are able to buy exclusive harvesting rights through an auction system and are required to implement self-monitoring and enforcement. A meeting of the board with the provincial departments, and Chairmen of DPC and CPCs review and revise harvesting agreements, while at the local level monthly meetings are held between the board and the buffer zone CPCs to exchange information and experiences on management and local livelihood development.

An important, and perhaps unique feature of Xuan Thuy is the role that MARD plays in granting the PPC and management board permission to pilot co-management of sustainable resource use. However, the case is not a complete break from normal practice, as the PPC maintains decision-making control relating to park management. The key difference is that the management board maintains the authority to communicate with MARD and the DPC, and the Nam Dinh PPC is required to contribute $15 \%$ of revenues raised from clam harvesting directly to the management board and marine conservation activities (Hong and Cach, 2007), while $70 \%$ of taxes from clam cultivation licenses are transferred to the DPC budget. The system has been effective in resolving conflicts between communities in the park and nature conservation goals (Hong and Cach, 2007). These communities have also taken up a direct self-enforcement role, replacing state forest 
rangers, as they benefit financially from monitoring natural resource exploitation, engaging in nature conservation clubs, and building relations with the management board.

\section{Comparative Analysis and Discussion}

The results illustrate a range of networked relations, in both vertical and horizontal dimensions that constitute co-management in Vietnamese SUFs. These linkages highlight a diversity of local contexts and conditions that influence the make-up of these comanagement arrangements, as well as the degree to which locally-embedded actors are able to engage and draw upon the resources and influence of national and international actors and organizations (Plummer and FitzGibbon, 2006). Reflecting the work of Ratner et al. (Ratner, Oh et al., 2012), our analysis also highlights the need for a more critical institutional perspective to co-management which can not only identify these networked relations, but also focus on the internal dynamics of state interaction and how they affect the capability of communities to engage in cooperative forms of conservation in state run SUFs. We now turn to a comparison of the four SUF cases and draw what they show us in terms of dealing with and potentially overcoming the predominant "administrative" mode of SUF co-management in Vietnam.

Our first overall observation is that SUF management in Vietnam has not yet fully shifted from a (centralized) state-based model of management to an effective form of comanagement at the site level. As we argue elsewhere, co-management remains administrative rather than participative in nature (KimDung, Bush et al., 2013). Although a diversity of actors are present their contribution to day-to-day management is limited because of an unequal division of political and fiscal control by the PPCs. Despite the promise of co-management in SUFs, management boards rely heavily on the allocative power of vertically "higher" actors (Sandström and Rova, 2010) to organize and operationalize horizontal relations. Under these conditions, links to "horizontally" positioned actors are often stifled because on-site practices have not yet integrated participative mechanisms for sharing responsibilities, resource exploitation, and benefitsharing.

Despite all four case studies being explicitly labelled as "co-management", we also observe clear differences in terms of how SUF management boards have countered the administrative control of PPCs (summaries in Table 4.2). Cu Lao Cham shows how the management board has managed to establish a degree of financial independence to the PPC which has allowed them to establish collaborative links with local communities through the CPC. This contrasts markedly to the management board in Khau Ca who, despite attracting 
considerable external funding, have not been able to establish an adequate level of administrative independence from the PPC, which has, in turn, limited the capacity of the board to establish meaningful community collaboration. In Nui Chua, the dependence on external partners rather than the PPC for funding conservation payments to marginalized communities has put the management board at risk of not being able to continue their engagement with local communities. Finally, in Xuan Thuy, the stronger vertical support by the MARD, in the context of national legislation related to Ramsar, has allowed the management board to largely bypass the control of the PPC in relation to their management activities.

All four cases demonstrate that the limitations of "administrative" co-management can be overcome by diverting power and control away from the PPCs. The PPCs control decisionmaking and hold key financial resources and determine (in large part) the participation of other executive bodies. Any attempt to engage local communities by management boards are, therefore, strongly dependent on the coordinating, authoritative, and financial capacity of a PPC. If a PPC holds nature conservation as a priority, and is willing to devolve power to others in the co-management network, they enable a participative, problem-solving form of co-management (see Table 4.2). However, if the PPC does not prioritize conservation, or community engagement, their central role and power can block the involvement of other (vertical and horizontal) actors and undermining the resolution of common interests, benefit-sharing and joint decision-making. Reflecting the challenges of "second generation" co-management (Ratner, Oh et al., 2012), it is these institutional dimensions of comanagement that play a fundamental role in shaping the distribution of benefits and risks to those involved in SUF management.

If the management boards can generate incomes for nature conservation and their own operation, they can become less dependent on PPCs. However, as illustrated in all four cases, any control levered back by management boards through alternative funding will remain partial given the control that PPCs exercise over land at the local level (Clement and Amezaga, 2008; Vietnam Government, 2010; PanNature, CORENAM et al., 2014). Such control does not only create a near complete reliance on the PPC for resources, it also affects the capacity of management boards collaborate with either alternative government bodies and/or local communities.

Although counter-intuitive to the goals of co-management (cf. Plummer and FitzGibbon, 2006), a more effective means of leveraging control back from the PPC may, instead, be to develop stronger centralized ties to MARD. As shown in the case of Xuan Thuy, the PPC has been forced by MARD's involvement to devolve authority to the DPC to manage resources and to the CPC to implement resource protection. If MARD, as an administrative central government actor, has the power to counter the dominant role of the PPC, and reorient collaboration of the management boards to the DPCs and CPCs, it 
might well be able to facilitate greater community engagement within the parks. By placing more emphasis on the role of central actors in co-conditioning and steering comanagement strategies and outcomes at the local level (Berkes, 2010), the management board has gained greater authority and capacity to monitor operations of resource exploitation and protection in the area.

Table 4.2. Comparing administrative co-management in four case studies.

\begin{tabular}{|c|c|c|c|c|c|}
\hline $\begin{array}{l}\text { Co-management } \\
\text { characteristic }\end{array}$ & $\begin{array}{l}\text { Networked } \\
\text { relation }\end{array}$ & Khau Ca & Nui Chua & Cu Lao Cham & Xuan Thuy \\
\hline \multirow[b]{4}{*}{ Vertical network } & $\begin{array}{c}\text { MARD } \\
\text { involvement }\end{array}$ & No & No & Yes & Yes \\
\hline & $\begin{array}{c}\text { Active and } \\
\text { facilitating PPC }\end{array}$ & Yes & No & Yes & Yes \\
\hline & $\begin{array}{l}\text { Devolution to } \\
\text { DPC }\end{array}$ & No & No & No & Yes \\
\hline & $\begin{array}{l}\text { Consulting and } \\
\text { learning } \\
\text { process among } \\
\text { actors in } \\
\text { vertical linkages } \\
\text { and with local } \\
\text { people }\end{array}$ & No & No & Yes & Yes \\
\hline \multirow[t]{3}{*}{ Horizontal network } & $\begin{array}{l}\text { Local people } \\
\text { collaboration }\end{array}$ & $\begin{array}{l}\text { Conflicts } \\
\text { with local } \\
\text { people }\end{array}$ & $\begin{array}{l}\text { Limited } \\
\text { collaboration }\end{array}$ & $\begin{array}{c}\text { Good } \\
\text { collaboration, but } \\
\text { local people } \\
\text { complain that } \\
\text { outsiders exploit } \\
\text { resources. Local } \\
\text { people have no } \\
\text { rights to stop } \\
\text { outsiders. }\end{array}$ & $\begin{array}{c}\text { Good } \\
\text { collaboration. } \\
\text { Local people } \\
\text { have clam } \\
\text { exploitation } \\
\text { rights. They can } \\
\text { prevent others } \\
\text { from poaching } \\
\text { their areas. }\end{array}$ \\
\hline & $\begin{array}{l}\text { International } \\
\text { involvement }\end{array}$ & Limited & Limited & $\begin{array}{l}\text { Strong financial } \\
\text { and technical } \\
\text { support }\end{array}$ & $\begin{array}{l}\text { Strong financial } \\
\text { and technical } \\
\text { support }\end{array}$ \\
\hline & Business & No & No & Yes & Yes \\
\hline $\begin{array}{l}\text { Cost and benefit } \\
\text { sharing }\end{array}$ & & No & No & Yes & Yes \\
\hline $\begin{array}{l}\text { Overcoming } \\
\text { financial and human } \\
\text { resource shortages }\end{array}$ & & No & No & No & Yes \\
\hline
\end{tabular}

Although central control by MARD is unlikely for all SUFs, nor particularly desirable, the cases reflect the need for understanding how greater political control can be created at different levels of government to implement forest management agreements, "with suitable rewards and penalties and scope for revisions as needed" (Boissiere, Sheil et al., 2009, p. 2755). This indicates the ongoing need for a balanced interaction between the PPC and management boards. If divided, as seen in the case of Nui Chua, management decisions 
may contradict the conservation and livelihood goals of the SUFs in question - a problem extending to various cases of hydropower and infrastructure development supported by PPCs (e.g. Ty, Westen et al., 2013). Weak cross-accountability of these organizations is also not desirable given the complex political economy of illegal forestry activity (Sikor and Phuc, 2011). In order to facilitate more meaningful community collaboration, and thereby break down the dominant administrative mode of co-management, greater awareness of the political dynamics of power and decision-making is required. As noted by Vasavakul (Vasavakul, 2014), this is particularly important given the growing independence of provinces in many areas of central policy.

Despite Vietnam, in some ways, being an outlier in Southeast Asia - as one of only two remaining centralized single-party socialist states - our results do hold broader lessons for a wider critical institutional perspective of co-management. Reflecting on Ratner et al.'s "second generation co-management" Ratner, Oh et al. 2012 our findings also point to the need to consider institutional competition between government actors across multiple levels in the governance of co-management (see also Berkes, 2009; Armitage, Berkes et al., 2010). Furthermore, we concur with their argument for also taking into account relations both between public and private actors and examining the extent to which these relations contribute the conditions under which co-management can be implemented Ratner, Oh et al. 2012. By opening co-management to wider notions of networked governance relations it is then possible to go beyond the more standard analyses of vertical linkages between states and resource users or managers. By adopting this networked approach, and critically investigating the norms, rules, and relations that constitute cooperation in these networks (Adger, Brown et al., 2005; Ratner, Oh et al., 2012), we can better understand other horizontal linkages and (social) relations that enable resources and managers and users to improve the terms of their involvement in highly contested practices, such as conservation (cf. Sikor and Nguyen, 2007; Ribot and Larson, 2013). Again, reflecting the findings of Ratner et al., this emphasizes the importance of taking into account the competition for resources that would not otherwise be considered in the more traditional perspective of a vertical state-community collaborative management models (e.g. Sen and Nielsen, 1996). Finally, while our results did not incorporate issues of adaptation and learning, we do acknowledge the importance of these characteristics on second-generation co-management. While other countries in Southeast Asia may be less centralized, and/or have more opportunity for collective action than communities in Vietnam, all exhibit a tension between central and de-central actors that either enable or hinder the implementation of co-management. A critical institutional perspective allows for a more in depth analysis of the relevance and potential for co-management in this context.

Second, the results reiterate the importance of understanding the benefits and risks associated with investing in co-management. After two decades of experimenting with 
decentralized natural resource management in Southeast Asia, evidence of the "tyranny" of policy discourses such as co-management is emerging (cf. Cooke and Kothari, 2001). As the language of co-management is mainstreamed, there is a growing risk that it is used as a means of justifying government involvement and ultimately re-centralization of resource control away from resource users (e.g. Ribot, Agrawal et al., 2006). In Vietnam administrative co-management may be more about maintaining central control, but the institutional dynamics behind this process may open up similar cases in other political settings.

\section{Conclusions}

The results show that, far from enabling improved collaborative management of SUFs, the strong administrative intervention of the political branch of the Vietnamese government both facilitates and undermines the functions of management boards in performing their mandated duties. To be able to adapt and sustain the SUF management system to local and constantly changing conditions, SUF management boards need to continue to push for a mix of flexible and adaptable horizontal relations within the still rigid structure of vertical state control. Identifying how they can do this requires a more nuanced understanding of the purpose, interests, and resources of actors, as well as their performance in comanagement.

From the range of strategies adopted by management boards to overcome these constraints, it appears that engagement with strong vertical networks of interrelated state authorities might be the most effective means of gaining enough independence to implement management activities and engage with local communities. In addition to this vertical strategy, the results also demonstrate that the capacity of management boards to perform their mandated functions improves when working with international organizations and when they introduce benefit-sharing mechanisms for local communities. The results also show that the limitations of administrative co-management can be overcome when multiple actors (both horizontally and vertically) are involved. However, their involvement does not necessarily equate to a weakening of state power. It is still the state, represented by the PPC, and its extended vertical networks that enable, facilitate, and condition these horizontal inter-linkages and collaborations. For SUF co-management to effectively move beyond its administrative character, and better facilitate horizontal network collaboration with local communities, allocative power has to be devolved from provincial and ministerial levels to commune and/or district governments. 
Further research is needed to determine whether and how administrative forms of comanagement are visible in other states exhibiting centralized state management of natural resources. In doing so attention should be given to the extent to which networked forms of co-management are able to overcome centralized control. Extending beyond the single case of Vietnam, a wider typology of how states facilitate the inclusion of actors that go beyond the traditional vertical relationships can lead to a more informed understanding of comanagement in political contexts that do not exhibit high levels of devolution and deliberative decision-making. By developing such a typology a more adaptable set of principles may emerge that allow for the design of co-management in contexts where it is appears least possible. 


\section{Chapter 5}

\section{NGOS AS BRIDGING ORGANIZATIONS IN MANAGING NATURE PROTECTION IN VIETNAM ${ }^{6}$}

\section{Introduction}

Vietnam has a long history of centralised control over forest resources. Starting with policies prohibiting forest use in the 1960s, the government established a series of reforms over the next 50 years designed to balance this centralised state control with greater representation of local resource users (Tu et al., 2014). But while these reforms have led to a gradual decentralisation of implementing forest law and policy, an ongoing tension remains between centralised control by key Ministries at the national level and the administrative control of forest resources at the provincial level (Tu et al., 2014). The practice of resource users has to a large extent remained largely rhetorical (e.g. Sunderlin, 2006; Boissière et al., 2009). It is this tension between centralisation and decentralisation that underscores the strongly administrative character of decentralisation in the management of forest resources beyond the state to resource users or other civil society groups (Sikor and Nguyen, 2007; KimDung et al., 2013). In this paper we explore this tension in the context of so called 'Special-Use Forests'.

Special Use Forests (SUFs) were introduced in 1986, by Ministry of Forestry (today MARD - Ministry of Agriculture and Rural Development). In the Decree, SUFs were defined as national property forests established to protect and conserve forest habitats, genetic resources of endemic flora and fauna, landscapes and sites with cultural and historical value, as well as providing resources for scientific research and education (Vietnam Government, 1986). Since 1993, the Vietnamese government has strengthened the SUF system to meet obligations of the Convention on Biological Diversity and the Ramsar Convention by increasing the area protected (Zingerli, 2005). Today SUFs are considered 'the backbone of the national protected areas system', with 161 SUFs making up 2,1 million hectares or $15.7 \%$ of total forest area - and also extend to cultural and historical sites, grasslands, freshwater lakes, and coastal and marine areas (MONRE, 2011b; PanNature, 2011a).

\footnotetext{
${ }^{6}$ This chapter has been published as KimDung, N., Bush, S., \& Mol, A.P.J. (2016). NGOs as Bridging Organizations in Managing Nature Protection in Vietnam. Journal of Environment and Development, 25(2), 191-218.
} 
Despite this significant expansion of SUFs, a range of resource-related conflicts in and around SUFs persist. It is estimated that $80 \%$ of SUFs are currently inhabited (Cuong et al., 2009), meaning many communities remain dependent on forest resources for their livelihoods. Continued land right claims in and around SUFs have led to conflicts between local users and authorities responsible for nature conservation (Sikor, 2001; Zingerli, 2005; Coe, 2013). Other evidence has pointed to the lack of alternative income opportunities for communities living around SUFs as a cause of continued levels of exploitation (Sikor and Nguyen, 2007; Boissière et al., 2009). In Vietnam, like many other developing countries (Sunderlin, 2006), prohibiting natural resource use in protected areas provides no incentive for responsible and sustainable use; rather, local residents maximise resource exploitation as opportunities arise.

Faced with these challenges, the Vietnamese government, in collaboration with a range of national and especially international conservation organizations, has attempted to institutionalise co-management in SUFs by engaging local stakeholders in protected area management (Boissière et al., 2009). In 2003, the Government ratified the Management Strategy for Protected Area System in Vietnam introduced a stronger focus on comanagement as a means of resource management (Vietnam Government, 2003). However, meaningful community engagement through co-management remains constrained by a lack of support to devolved management responsibilities to communities, the lack of a legal framework for local government to allow for creative and proactive community decisionmaking and planning, and the weak inclusion of non-state actors such as NGOs (USAID 2013). As KimDung et al. (2013) argue, SUF co-management in Vietnam therefore remains 'administrative' in that managers must respond to centralised directives from the central government over finances and economic partnerships with non-state actors, rather than steering and supporting resource users to foster creative and effective management practices.

Where state and community capacity is limited in natural resource management, as often seen in developing countries, NGOs are recognised as 'bridging organisations'. As implied by the term 'bridging', these NGOs do not supplant existing actors or institutions, but instead seek to increase co-operation, empowerment, and social capital in natural resource governance by building trust, and by constructing common vision and goals among actors in a co-management arrangement (Folke et al., 2005; Berkes, 2009; Schultz et al., 2011). Although often not a primary goal of these NGOs, bridging functions allow them to seek win-win solutions for both biodiversity conservation and community development. Despite the administrative nature of Vietnamese co-management, previous research in Vietnam has indicated that NGOs can play a bridging role by facilitating eco-tourism projects and ecocertification, as well as enabling in scientific and capacity building, and mediating resource conflicts (García-Herrera, 2009; Fabres, 2011). 
Yet other research has shown that the bridging roles of these NGOs in Vietnam are fundamentally constrained by the political and operational constraints of the Vietnamese government (Lux and Straussman, 2004). Establishing and running national/local NGOs in Vietnam is still very much state controlled through the role of the Vietnamese Fatherland Front, a parastatal 'mass organisation' responsible for political mobilisation with close ties to the Communist Party (Nghia, 2011). The result is that political space for advocacy by these (inter)national NGOs, is constrained by the lack of a clear legal framework and by controls over their largely internationally sourced funding (Pham et al., 2014). These factors are further compounded by the often ambiguous role and relationship between NGOs, as representing civil society, and the state at multiple levels of government (Hannah 2009; Nghia, 2011). Despite the clear potential for NGOs as bridging organisations it is not selfevident that they can play this role in the current practice of Vietnam's 'administrative' mode of natural resource co-management.

In this paper we investigate how and to what extent NGOs in Vietnam function as bridging organizations in administrative co-management of SUFs. The results demonstrate that NGOs can only partially fulfil the role of bridging organisations and overcome the constraints of the administrative mode of co-management seen in Vietnamese SUFs. In doing so we contribute to wider debates on the role of NGOs as bridging organisations in developing countries where co-management continues to be a central policy goal, but remains constrained by a lack of space for independent political advocacy and policy intervention.

We now turn to an review of the potential role of bridging organisations in facilitating more adaptive co-management arrangements, before outlining four key variables against which the extent of NGO functionality as bridging organisations can be assessed. We then present and analyse the results of a two-stages empirical investigation based on a national survey of SUF managers on their experiences and expectations of co-management (including engagement with NGOs) and four in-depth case studies of NGO engagement in SUFs management.

\section{Bridging organizations in natural resource co-management}

Co-management captures the idea that rights and responsibilities in natural resources management should be shared between government and any non-state actor (including resource users, local communities, environmental NGOs or scientists) (Plummer, 2009). Co-management is advocated not only because it holds the potential to enhance the effectiveness of natural resource protection and management, but also because it brings 
stakeholder participation and therefore fairness, transparency, legitimacy and accountability to management (Plummer et al., 2013).

However, for co-management to be effective it is commonly argued that more flexible and 'adaptive' processes of decision making are needed (e.g. Fabricius and Currie, 2015). More effective co-management strategies is expected to facilitate local level processes of experimentation with different measures to see what works and adapt policies and management strategies in the light of lessons learned and new situations and conditions (Armitage et al., 2009). Adaptive co-management has therefore been widely formulated (Folke et al., 2005; Plummer and Armitage, 2007; Armitage et al., 2009) as an approach to involve heterogeneous actors and cross-scale interactions. As outlined by Cash et al. (2006), these interactions are conceptualised as both 'horizontal' (within scale) and 'vertical' (crossscale) network connections that facilitate learning through feedback, emphasise social processes that encourage flexibility in governance, and build governance capacity for adaptation.

In developing countries the ability of co-management to facilitate these cross-scale interactions is often constrained by degrees of political space afforded to civil society groups. The wider tendency for centralised state control over natural resources often means that international goals for the decentralisation of conservation and empowerment of resources users conflict with aspirations of 'state making' and the underbelly of elite capture (see Persha and Andersson, 2014). Within this context 'bridging organizations' have been identified as a potentially important factor for the success of co-management of natural resources in developing countries (Plummer, 2009). Introduced in the early 1990s (see Westley and Vredenburg, 1991) bridging organizations link multiple actors in horizontal and vertical networks to facilitate decentralisation, increase policy learning and contribute to wider goals of sustainable development.

While bridging organizations have been extensively discussed in the adaptive management literature to focus on social capital and co-production of knowledge (e.g. Berkes, 2009; Crona and Parker, 2012; Rathwell et al., 2015), we use it in its original meaning given by Brown (1991) to refer to a "conduit of ideas and innovations, a source of information, a broker of resources, a negotiator of deals, a conceptualiser of strategies [and] a mediator of conflicts" (p. 812). We therefore identify bridging organizations as organizations that coordinate and facilitate collaboration across organizational levels and knowledge systems by enhancing networking between various actors, strengthening social capital and capacity of stakeholders (most notably local communities), and addressing problems at and between multiple scales (Berkes, 2009; Schultz, Duit et al., 2011). But while there is a growing number of studies that outline the potential of bridging organisations in co-management, arguably fewer have focused on developing countries, and even less on the institutional dimensions of states exhibiting a strong tendency towards centralisation (see for exception 
Pham et al., 2010). Instead most studies focus on states with an existing tendency for decentralisation and participatory resource management (e.g. Pahl-Wostl et al., 2007; Rathwell and Peterson, 2012). Questions therefore remain as to the extent NGOs can function as bridging organisations in countries like Vietnam, where aspirations for comanagement have been limited by centralised political and administrative control.

From the literature we have distilled four ways in which international and national NGOs perform bridging roles in natural resource management settings in developing countries (see Figure 5.1). First, bridging organizations are believed to provide a forum for interactions of different knowledges, ideas and information from different actors, such as researchers, decision-makers at different levels, companies, and local communities. As such they communicate, translate, and mediate (scientific and lay-actor) knowledge, information and ideas, and make these (sometimes combined/integrated) knowledges and information relevant to policy and action (Folke et al., 2005; Vignola et al., 2013). Second, these organizations facilitate and play a major role in formulating common visions and goals among all actors in co-management arrangements and in doing so enhance trust between those involved (Berkes, 2009). Third, bridging organizations facilitate and increase cooperation between different governance levels and actors of governance, in terms of networking and relations within co-management networks as well as with the outside world (Folke et al., 2005). As such, they bring together resources from various governance actors, facilitate cooperation and communication between these actors, and help adjust ineffective, contradictory or counterproductive rule systems at different levels. Fourth, bridging organizations also support the emergence of participatory and collaborative approaches, and especially the empowerment and increased social capital of local community stakeholders; which in turn can lubricate future collaborations in the arrangements (Schultz et al., 2011). In developing countries, communities remain often weakly organised, marginalised from decision making, and rarely have technical, financial and human resources and capacity to engage more pro-actively in decision-making spaces offered (Larsen, 2008). Bridging organizations are specifically aimed at changing this.

NGOs can have this 'bridging ability' with respect to natural resources and environment because of perceived independence (and therefore legitimacy) in transition processes (Affolderbach et al., 2012; Shah, 2011). In co-management, NGOs can thus bridge interests and perceptions of actors and create a flexible environment and space for discussions and negotiations in decision making. And as Folke et al. (2005) point out, larger and especially international NGOs can also provide financial, technical and knowledge support to introduce new approaches of nature conservation to localities, and strengthen social capital and capacity for effective multilevel governance and ecosystem management. The rest of 
the paper examines to what extent NGOs do fulfil this bridging role in the context of Vietnamese SUF co-management.

BRIDGING CAPABILITIES

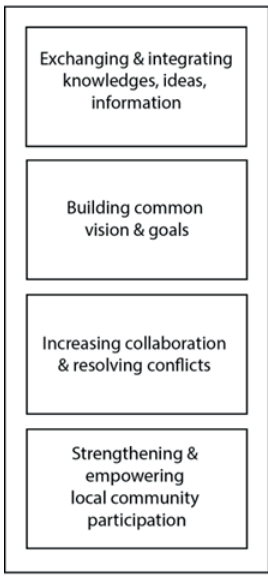

CROSS SCALE NETWORKS

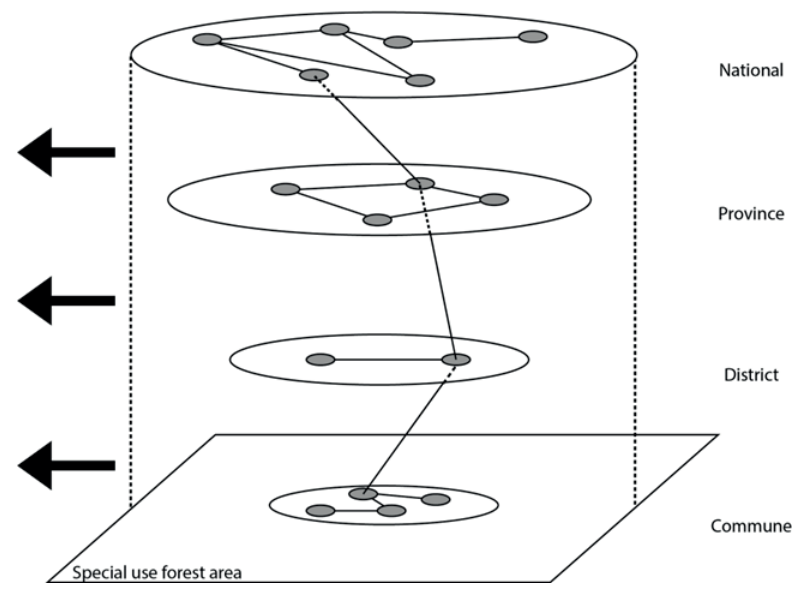

Figure 5.1. Roles of NGOs as bridging organizations in natural resource management

\section{Methodology}

The research uses two sets of data. First, a national survey of 113 of the 161 Vietnamese SUFs Management Boards (MBs) was undertaken in 2009 to collect data on the type and degree of involvement in co-management (see KimDung et al., 2013). In this paper we have used a subset of this data to focus on the content of SUF and NGOs collaborations, expectations of SUF managers toward the collaborations, and the extent to which SUFs can bring other actors in the collaborations. A summary of the specific questions relevant for this partial analysis of the overall survey are listed in Table 5.1.

Second, four in-depth case studies were selected from an initial scan of ten NGOs involved in natural resources management in Vietnam. ${ }^{7}$ The four cases were Fauna \& Flora

${ }^{7}$ The ten NGOs involved in co-management in the initial scan included Action on Poverty, CARE Vietnam, Fauna \& Flora International, International Union for Conservation of Nature, Centre for Marine life Conservation and Community Development (MCD), People and Nature Reconciliation (PanNature), People Resources and Conservation Foundation (PRCF), Vietnam National Park and Protected Area Association (VNPPA), World Vision, World Wide Fund for Nature (WWF). 
International (FFI), the Vietnam National Park and Protected Area Association (VNPPA), a national professional association classified as a civil society organization (Nghia, 2011); the Vietnamese NGO Centre for Marine life Conservation and Community Development (MCD); and the Vietnamese NGO People and Nature Reconciliation (PanNature). These cases are selected based on a variety of reasons. First, all four are leading NGOs working toward a co-management or community-based movement to preserve natural resource and sustainable development in Vietnam (FFI, 2013; Parr, 2013; IIED, 2015; PanNature, 2015b; VNPPA, 2015). Second, we have sought divergent cases categorised in terms of their engagement at the international level, either coming from another country (FFI), being funded internationally (MCD), and having primarily their engagement with the Vietnamese government at the local (PanNature) and national level (VNPPA). Third, the four NGOs have explicitly shown to support co-management in SUFs (Khau Ca, Xuan Thuy, Nui Chua) where we have a set of data available for analysing collaboration between SUF MBs with stakeholders, including NGOs, local people, private sectors, scientists and various state agencies.

Table 5.1. Summary of survey questions

\begin{tabular}{|c|c|}
\hline No. & Questions \\
\hline 1 & List names of all NGOs that your SUF has collaborations with. \\
\hline 2 & Define the roles of NGOs in these established collaborations. \\
\hline 3 & Provide the content of projects that are implemented in collaboration with NGOs. \\
\hline 4 & $\begin{array}{l}\text { Do you strongly agree/agree/neutral/disagree/strongly disagree with the statement; "The state policy } \\
\text { recognizes the historical values and customs of indigenous people when considering harvesting and using natural } \\
\text { resources". }\end{array}$ \\
\hline 5 & $\begin{array}{l}\text { With which level of government do you prefer to strengthen collaboration (central, provincial, district, } \\
\text { commune)? Explain your preference. }\end{array}$ \\
\hline 6 & $\begin{array}{l}\text { With which sectors/stakeholders (local people, private companies, public companies, NGOs, } \\
\text { research/education institutions, police, military, Vietnamese Fartherland Front) do you prefer to } \\
\text { strengthen collaboration? Explain your preference. }\end{array}$ \\
\hline
\end{tabular}

The four case studies are analysed and compared using the four characteristics of bridging organisations outlined above and summarised in Figure 5.1. In doing so the cases seek out 'typicalities' across four different cases, as well as commonalities between the cases (Flyberg, 2006). We do not set out to rate or rank the cases, nor the NGOs involved. Qualitative data for the case studies was collected through interviews with the four NGOs and the various public and private organisations they collaborate with, as well as with local communities living in or nearby the SUFs these NGOs were engaged with. The interviews were recorded and analysed using coding corresponding to the four dimensions of bridging organisations outlined in section 2. Additional observations and discussions were conducted during two national workshops on SUF management held in Hoa Binh province 
(May 2013) and Ho Chi Minh City (September 2013), and through secondary data sources such as reports, policy documents and NGO websites.

\section{NGOs in Vietnamese administrative co-management arrangement of SUFs}

The SUF management in Vietnam is highly centralised, with MARD responsible for their administration. Within MARD, the Forest Protection Department (FPD) plays a key role in monitoring and managing the SUF network through its provincial and district level implementation entities (Vietnam Government, 2003; USAID, 2013). Responsibility for protected areas are also shared with other branches of government, including the Ministry of Natural Resource and Environment (MONRE), the Ministry of Culture, Sports and Tourism Ministry of Police, Ministry of National Defense for law enforcement, Ministry of Planning and Investment, and Ministry of Finance for SUF finance and investment (Vietnam Government, 2001; USAID, 2013; Vietnam Government, 2010). At the provincial level the Provincial People's Committees (PPCs) are state administrative organizations assigned to manage all SUFs within entire provincial boundaries. The PPCs can assign SUF management directly through Departments of Agriculture and Rural Development (DARDs) or pass on the responsibility for specific tasks such as tourism development to district governments (USAID, 2013). At the (local) operational level, SUF MBs are assigned ownership rights over forest management, protection and development and staffed by officials assigned from provincial DARDs (Vietnam Government, 2010). Where MBs have not been established, SUFs are under the management authority of either District FPDs, Provincial DARDs, or Provincial Departments of Culture, Sports and Tourism (Vietnam Government, 2003, 2010; MONRE, 2011b).

There are more than 23 international and Vietnamese NGOs (INGOs and VNGOs) operating in SUF management. INGO involvement is encouraged by the Vietnamese government, but limited to the provision of development aid, and prohibited from activities relating to politics, religion and other issues which are incompatible with the Vietnamese national benefits, security, defense, and solidarity (Decree 12/2012/ND-CP). The Nationallevel Vietnam Union of Friendship Organizations (VUFO) is responsible for INGO relations, while the PPCs are tasked with overseeing INGOs within their jurisdictions in close collaboration with a national level inter-ministerial body (COMINGO). In contrast, VNGOs have to be registered under a governmental agency - most commonly the Vietnam Union of Scientific and Technological Associations (VUSTA), which belong to the parastatal Vietnam Fatherland Front led by the Party (iSEE et al., 2008; Vietnam Fatherland Front, 2008). 
INGO support in Vietnam is steered towards the national strategy for poverty reduction, with priorities set for the development of agriculture, forestry and fisheries. Within these sectors, the government seeks INGO support for cross-sector support, direct intervention in selected livelihood activities, enhancing community participation, infrastructure construction, and enhancing community-based wildlife and biodiversity protection (Decision 40/2013/QD-TTg). In comparison, VNGOs are directed towards environmental protection, community development, and capacity enhancement, and less to grassroot democracy and public governance (iSEE et al., 2008). In addition, VNGOs suffer from even more unstable budgets and less clear strategies than their international counterparts, largely because they are dependent on the requirements and strategic themes of international partners and sponsors (iSEE et al., 2008).

Our survey shows that according to SUF managers NGOs play a minimal role in SUF management, and where they are involved they are not reported as exhibiting a bridging role. Only one third of SUF managers $(n=113)$ reported having ever worked with INGOs who provided technical input and funding for tasks mandated for SUFs by the government. NGOs are not reported by SUF managers as facilitating knowledge transfer, building common goals, managing conflicts or strengthening community empowerment. The results also show that just over one third (37\%) of SUF managers agreed with the statement that "the state policy recognised the historical values and customs of indigenous people on harvesting and using natural resources", while $87 \%$ of SUF managers saw the absolute need for input from local people in formulating collaborative policies. Instead, building on the notion of administrative co-management, the competent governmental authority collects input from SUF managers, scientists, and representatives from other governmental agencies, such as MONRE, PPC, and DONRE.

Overall these results show a divide between government and NGO experiences and expectations around co-management. Despite the investment of NGOs in capacity building and awareness raising SUF managers are not aware of (or willing to recognise) the investment that NGOs are making in building SUF co-management. From this national level analysis, the bridging function of NGOs appears to be only partially successful in integrating local knowledge and ideas into policies to serve nature conservation and development. 


\section{NGOs as bridging organizations: four case studies}

Using the four characteristics of bridging organisations outlined in section 2, we now analyse four NGOs working to establish co-management in SUFs. A summary of these case studies is provided in Table 5.2 as a guide to reading.

\subsection{Fauna \& Flora International (FFI) - International NGO}

Fauna \& Flora International (FFI) is an international conservation NGO focused on raising public awareness around the loss of Vietnamese biodiversity. FFI sees itself in the vanguard of organizations developing co-management models in Vietnam nature conservation, and has several projects across the country (FFI, 2013; Parr et al., 2013). The most prominent of these is their primate program in the north of the country.

FFI bases its science driven programme on long-term data collection which is shared with a broad group of government and community stakeholders to advocate new approaches to SUF conservation. FFI also collaborates with other NGOs in delivering these workshops. However, feedback from local officials who attend these meetings argued that the information and ideas of co-management being presented were incompatible with state laws and regulations to be implemented. National level officials also stressed that any form of co-management should be understood and implemented in a 'Vietnamese way' rather than adopting international practices. The 'Vietnamese way' refers to their concerns about 'sensitive issues' brought in SUF management by international practices of co-management in which community/private property rights (of SUF land and forest resources) and 'power sharing' are vital and transparently exercised during processes of co-management. The current structure of SUF management and laws are not transparent and elaborated in accordance with these international aspects. 


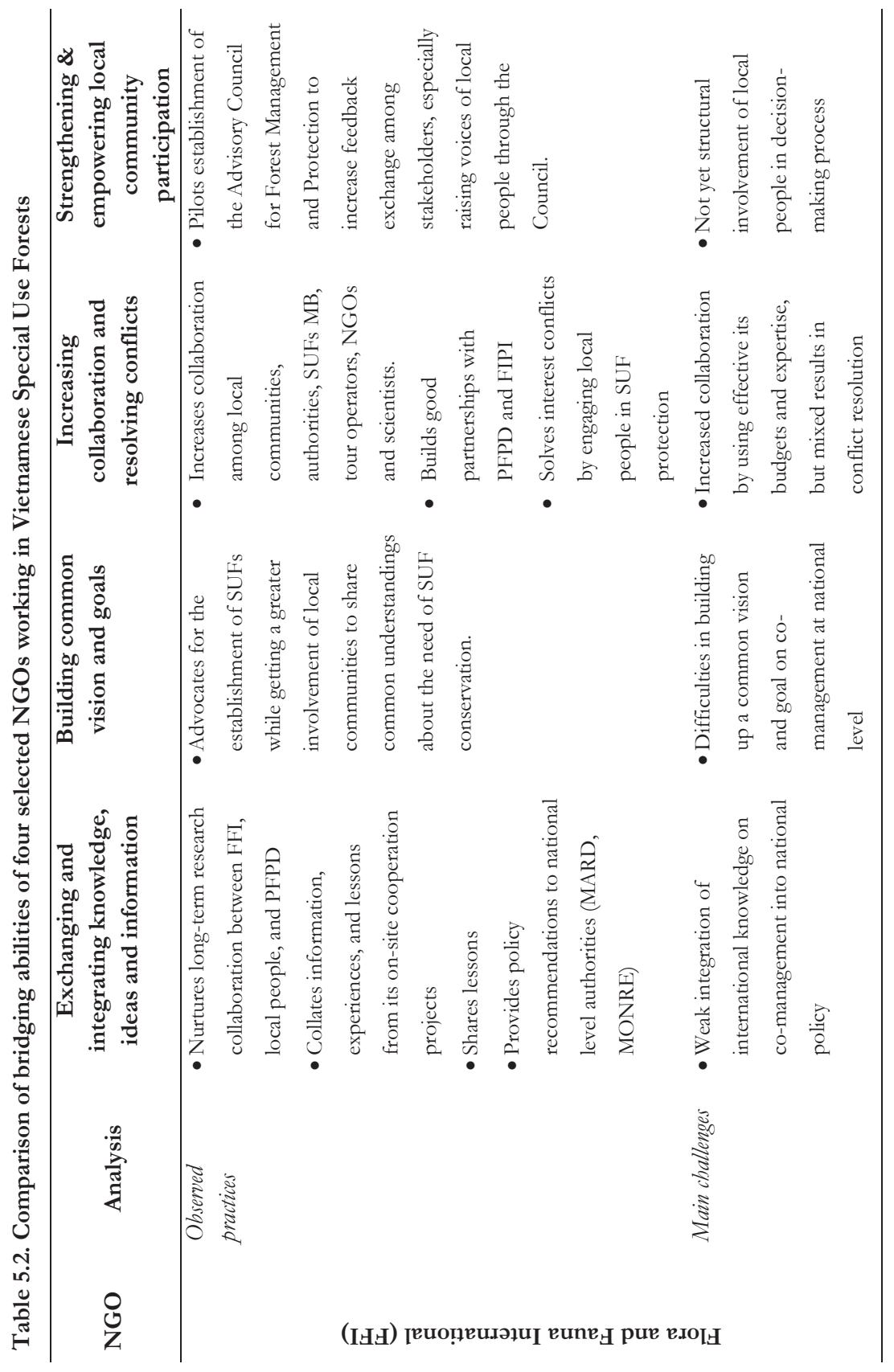

ํㅡㅇ 


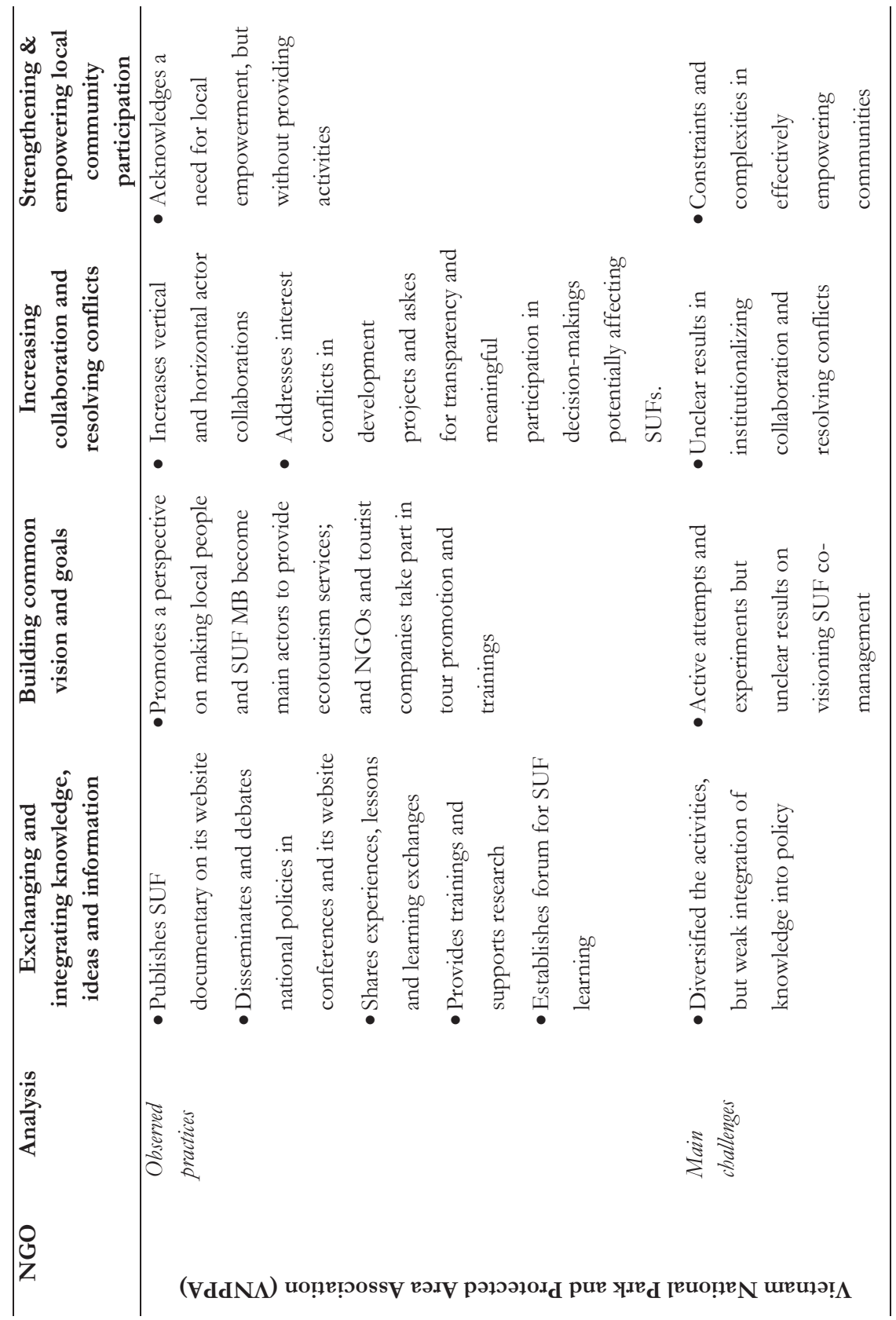




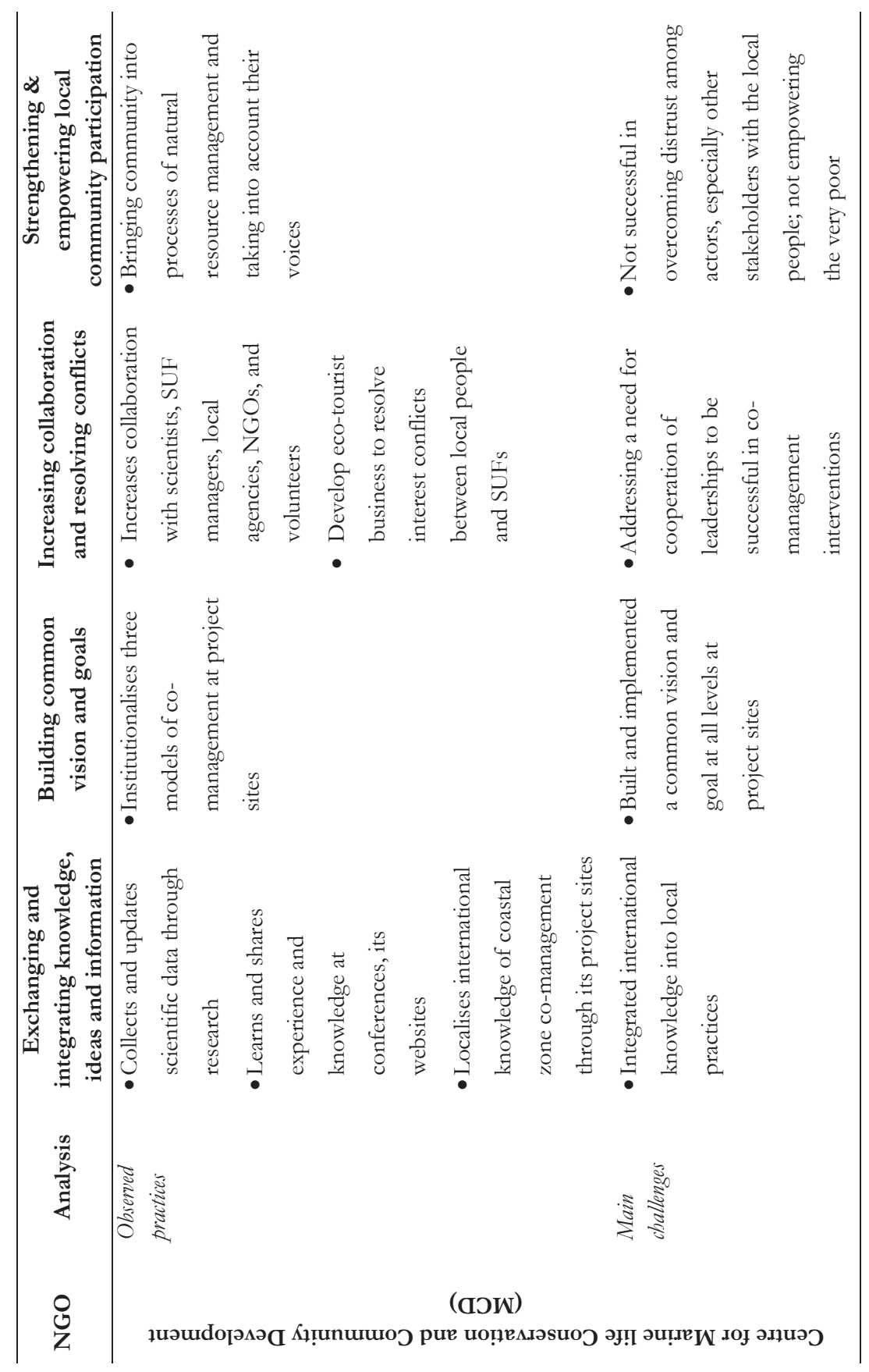

ล 


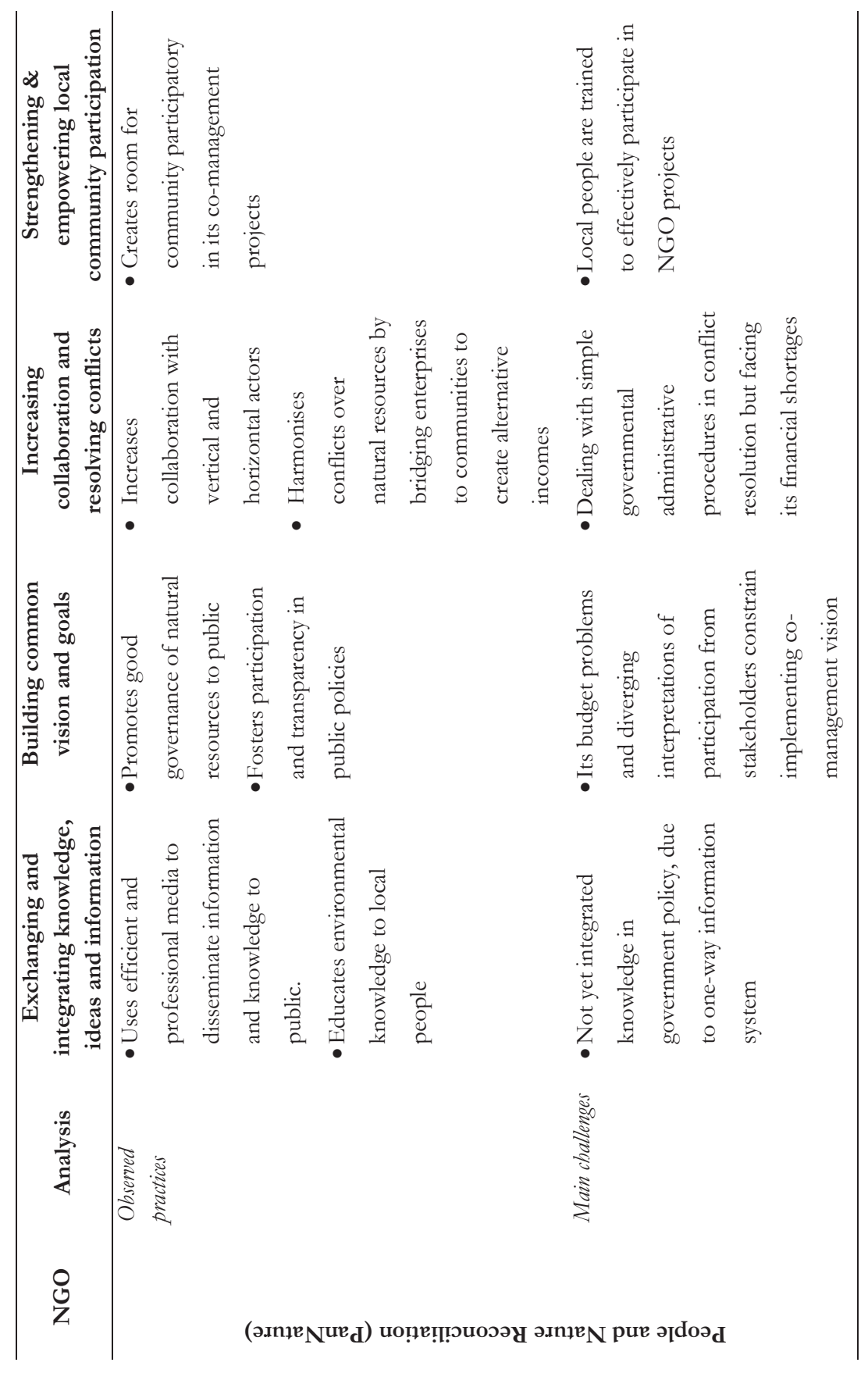


FFI has also sought to strengthen policy and practice around SUF management by working closely with the provincial level Forest Protection Departments (FPD) and the national level Forest Inventory and Planning Institute (FIPI) - a forestry scientific organization belonging to MARD and having legal power and responsibilities to consult the government about SUF network development across the country (PanNature et al. 2014). But again, FFI experienced difficulties in overcoming administrative procedures set by the government, which to some extent limited FFI's activities in the field with local communities and SUF managers. Consequently, FFI activities have centred on discussing and disseminating research results with policy makers, sharing lessons learned at national conferences and commenting on national policy drafts.

FFI has also had mixed results in balancing conservation goals with livelihood priorities of local communities who are often in direct conflict with the strict no-use SUF management regime. FFI attempts to support programmes aimed at enforcing SUF regulation, while balancing conflicts of interest with these local communities. In their words, they have sought to "bridge locals and the projects" by implementing gun controls and community ranger groups. Through these activities FFI has enjoyed a degree of success in catalysing collaboration between forest rangers and local people via local patrol groups and has successfully addressed short-term threats of hunting to biodiversity. However, the NGO has not been able to institute long-term policy change, nor directly address conflicts between local communities and rangers.

Finally, there is incidental evidence that FFI has enabled local communities to engage in participatory land use planning and zoning activities, and raise their concerns to local governments. For example, FFI piloted an Advisory Council for Forest Management and Protection in the Mu Cang Chai SUF consisting of local representatives from communes around the SUF, and advised the $\mathrm{MB}$ on area management. According to a FFI representative, many minority groups were willing to give opinions through this Council. But these moments of engagement are ad hoc in nature. Although local communities are involved in protected area management, they have no structural role in decision making processes. Instead SUF management is coordinated by governmental organisations, limiting the influence of local people and NGOs like FFI.

As an international NGO, FFI collaborates with the Vietnamese government at all levels. Within the limited legal, political and administrative space offered by the state, FFI fulfils some bridging roles, by enhancing SUF law enforcement while attempting to reduce negative impacts on livelihood by increasing community participation. But overall, FFI is focused more on providing and exchanging knowledge on nature conservation rather than on local people empowerment which is regarded a political issue. To overcome these constraints FFI seeks collaboration with other NGOs and economic actors and works with 
'on-site officials' to overcome administrative limits placed on field visits and implementation of FFI activities.

\subsection{Vietnam National Park and Protected Area Association (VNPPA) - Vietnamese Civic Association}

The Vietnam National Park and Protected Area Association (VNPPA) is a member-based mass organization representing SUFs. The VNPPA receives political support from the state, like other Vietnamese civil organisations (Nghia, 2011), by creating a network of highranking public servants with expertise in nature conservation. It describes its role as disseminating legal documents and policies of the Party and the government on SUF management and protection of the people, and consulting with the government on strategies of SUF development and protection and buffer zone investment (VNPPA, 2015).

The goal of the VNPPA is to promote public awareness on nature conservation and support biodiversity protection by involving communities in SUF buffer zones. To achieve this the VNPPA facilitates collaboration and information exchange between SUF MBs, central government agencies, and international partnerships with Japanese, Chinese, and European national parks. The Association also disseminates more general information on biodiversity, environmental education, and ecotourism development, and by participating in project assessment, as well as providing SUF staff with training and technical support to undertake research and organise scientific workshops. But despite being highly active the organisation has had little success in integrating different knowledges from these different sources into national SUF policies because, in its words, the government has not yet considered voices of NGOs and other civil society organizations; and in return "civil society organisations have no right to request the government/policy makers to do anything except providing some recommendations for their reference" (Interview with VNPPA, 28th February 2011).

VNPPA also supports the creation of a common vision around SUF co-management by advocating the inclusion of multiple use and equal distribution of 'mutual benefits' from management and conservation in the national SUF policy framework. It has also supported the construction of ecotourism models that promote benefit sharing amongst stakeholders, especially with local communities. Additionally, VNPPA provides direct support to local people and SUF MBs to deliver ecotourism services, with NGOs and tourist companies taking part in tour promotion, advertisement, and human resource trainings. This approach to ecotourism is seen as a means of matching livelihood development and nature conservation, and of promoting investments in SUF buffer zone development. But despite these attempts at building a common vision around SUF co-management, there is little evidence of major results the VNPPA has achieved, neither in terms of working comanagement models, nor in terms of clear policy change. 
The VNPPA has also sought to reconcile conflict between actors involved in both SUF vertical and horizontal networks. For example, VNPPA has been active in creating a dialogue over the impacts of transportation and hydro-electricity construction projects in and around SUFs. As representatives from the Association argued, partnerships with other organizations have meant they have successfully lobbied for stopping projects that are harmful the conservation goals of SUFs. However, the VNPPA also believes that the absence of a strong civil society in Vietnam means systematic opposition to such projects remains limited. Additionally, VNPPA representatives argue that project information should be made public and transparent. Besides, they claim that SUF financial mechanisms such as profit sharing, investments and expenditures, and collaboration mechanisms are constraining the cooperation and engagement of economic actors in SUF management.

Because of local people's interests and knowledge VNPPA advocates a need for local people participation in SUF management. The VNPPA also acknowledges that knowledge dissemination requires the involvement of village elders as a first step in facilitating capacity building for participation in nature conservation. The diversity of ethnic minorities increases the complexity of effective collaboration and makes the work of bridging and empowering local actors in Vietnam SUF management difficult to deal with. When asked VNPPA assessed its role in nature conservation as being limited to supporting the Vietnamese government in developing strategies and plans on SUF nature conservation, providing technical support to SUFs, and organizing trainings and environmental education. It has not been able to engage with local empowerment of communities and facilitating their participation in SUF (co-)management.

\subsection{Centre for Marine life Conservation and Community Development (MCD) - Internationally funded Vietnamese local NGO}

The Centre for Marine life Conservation and Community Development (MCD) is a Vietnamese non-profit organization established in 2003 by the international NGO International Marinelife Alliance in close collaboration with the Vietnamese government. The organization is currently under the administration of the Vietnam Marine Science Technology Association. MCD works in only two SUFs, Xuan Thuy and Nui Chua, and is one of the few Vietnamese NGOs working on coastal development and conservation.

A strength of MCD is its capacity for exchanging and sharing knowledge by directly collecting information and managing relevant data for coastal resource and environmental management in the two parks. It then transfers these data into reports and material for national and international training courses. Conversely, MCD also disseminates global knowledge on integrated coastal zone management and co-management to local actors in their project sites. In doing so MCD seeks to localise international knowledge, and create 
transparency by documenting all output and feedback with the aim of influencing coastal management policies.

The vision of MCD is predominantly oriented to local participation and livelihood benefits. MCD's activities are therefore focused on innovating fishing practices, preserving coral reef, and improving environmental awareness of communities. It has introduced comanagement via a series of projects in Trao Reef (Khanh Hoa province), Xuan Thuy national park (Nam Dinh province), and Nui Chua national park (Ninh Thuan province) regulation, fishing policy and good aquaculture guidelines (Wyatt et al., 2011). These three models of co-management have been institutionalised into formal policies and regulations at the sites by commune and district governments. At the national level, these projects have been used as examples for promoting sustainable coastal resource management. Representatives at the Directorate of Fisheries (MARD) and the Vietnam Administration of Seas and Islands (MONRE), two of MCD's key partners, spoke highly of MCD as "one of Vietnam's top NGOs" in the field of nature conservation (Wyatt et al., 2011) .

Central to MCD's strategy for community-led conservation is to facilitate conflict resolution by supporting local people's livelihoods. MCD does this by playing a direct role in coordinating local authorities, private enterprises and governmental banks to support communities to develop eco-tourist business. Local people are taught how to determine markets, design tourist products, develop skills in tourist services, and advertise tourist products. Based on their experiences MCD advocates co-management smaller scale protected areas administrated by a few governmental levels and agencies, arguing that this leads to high success rates. MCD also argues that this localised approach is effective because of the challenges it faces as a Vietnamese NGO in advocating for change across all four levels of government from national to commune level. They argue that a key fundament of this localised approach begins with the development of local leadership and capacity building for coordinating the different government agencies and other NGOs that regulate and support livelihood and conservation activities.

MCD seeks to strengthen and empower local communities by advocating the high level of experience that fishers and resource users have in natural resource management. MCD bridges these experiences and knowledge by providing a voice in official meetings, where communities are often less able (or willing) to actively participate. However, despite these efforts, enterprises who work with MCD projects articulate that they do not have the capacity to work with local people, arguing that local people are unprofessional and unable to work with formal documents such as business contracts. Moreover, MCD is evaluated as rather weak in its ability to work with the very poor (Wyatt et al., 2011). MCD counters these claims by noting the difficulty of bridging economic actors with local people because of pre-existing high levels of distrust. 
Overall, MCD exhibits the characteristics of a bridging organization in terms of integrating international knowledge into local practices, building up a common vision and goal at project sites, increasing collaboration amongst a variety of stakeholders, and bringing community (interests) into processes of natural resource management. However, this NGO also has a limited bridging outreach because of the difficulty of coordinating institutional changes in a rigid four level system of government.

\subsection{People and Nature Reconciliation (PanNature) - independent locally funded Vietnamese $\mathrm{NGO}$}

PanNature is an officially registered VNGO, predominantly funded by international organisations, which supports conserving biodiversity and improving human well-being in Vietnam (PanNature, 2015). Recognising the "lack of adequate capacity at local levels ... for community-based conservation interventions" (Interview PanNature, date 14th March 2011), the organisation has aims to local processes of SUF management (see also PanNature, 2015). Overall PanNature experiences few difficulties with governmental administrative procedures because it is considered a Vietnamese NGO and is well regarded at the national state-level.

To promote knowledge and information exchange, PanNature publishes different types of reports on nature conservation and environmental protection. The NGO also attempts to build up a team of experienced and enthusiastic educators who can spread environmentallyfriendly attitudes and behaviour throughout society. Building experience with interactive activities and nature-based education programs also helps to promote environmental knowledge. However this knowledge is not yet integrated in government policy, because, according the NGO, it has been limited to a one-way exchange with government; such as voicing concerns about government policy in state sponsored national conferences.

A core activity of PanNature is to create a common vision around participation and transparency in conservation management policy. PanNature does this by advising the government on SUF laws and regulation, participating in policies debates, providing critical feedback on deficiencies in current policies and carrying out applied research and studies on SUF themes. Results from the research programs it supports are used to provide appropriate interventions in existing nature conservation and SUF policies and management practices. Although PanNature advocates the implementation of comanagement in small SUFs, representatives from the NGO recognise that the success of such models is hampered by the limited government budget to operate activities. The longterm involvement of a small local NGO like PanNature is therefore constrained by a lack of financial resources. 
PanNature attempts to increase collaboration at a policy level by building close relationships with MONRE, MARD, Vietnam Environment Administration, and Biodiversity Conservation Agency. The NGO has had success in doing so. For example, it plays a central role in policy making at the Biodiversity Conservation Agency. At the local level PanNature has also been able to address conflicts between nature conservation and local livelihood by bridging enterprises to communities through livelihood development projects. It also facilitates dialogue between provincial and district governments, SUF MBs, local people, other civil organizations and enterprises. While being a domestic NGO, and able to deal with governmental administrative procedures, the ongoing success of PanNature in continuing its work around conflict resolution is constrained by its dependence on international financial sources. To compensate PanNature has also sought funding partnerships with local enterprises by providing training on ecotourism and market supply with local agricultural and forestry products.

PanNature also works directly with SUF managers and local governments on comanagement projects, to create room for community participation. However, its impact as a local NGO has been limited, due to diverging perceptions around what 'participation' means for different key stakeholders. For example, SUF managers mostly believe that the areas they manage should be strictly protected through no-use regimes, as indicated in the law. However, PanNature desires more space for local people participation and sharing of benefits from joint forest use and thus sees it as its task to transform SUF boards from forest guards to forest managers who collaborate with communities. To achieve this the NGO has invested time and resources into providing local people with instructions, supervision and training in order to better include them in project activities.

In short, PanNature is an VNGO that adequately deals with simple governmental administrative procedures but experiences difficulties in maintaining suitable financial support for its operations. It therefore remains dependent on implementing projects that are 'dictated' by international sponsors, rather than what it sees as the most effective ways of engaging with SUF co-management. As a bridging organization, the NGO efficiently disseminates information and knowledge, fosters participation, increases collaboration in vertical and horizontal networks, and bridges economic actors with local people. But despite successes in influencing national level policy the NGO has been less successful at empowering local communities living in and around SUFs.

\section{Discussion}

As the results of both the national survey and case studies indicate, both VNGO and INGOs only partially fulfil the four tasks of bridging organizations. As such their impact in 
negotiating Vietnam's administrative co-management, and related centralised control, in SUFs appears limited. Instead, what we see is a state sanctioned role for NGOs in providing technical advice and assist in implementing designated activities (Lux and Straussman, 2004; Thayer, 2009). Given that the degree of autonomy of civil society from the Vietnamese state is often ambiguous (see Hannah, 2009), NGOs do not appears to fulfil the wider bridging role seen in natural resources management in other countries (e.g. Crona and Parker, 2012; Espinosa-Romero et al., 2014). We now discuss how the four case study NGOs have been able to partially fulfil the different bridging functions, and outline the limitations they face in overcoming an administrative mode of co-management.

The results show that all four of the NGOs studied have been successful to varying degrees in their attempts to foster information exchange and create of a common vision of comanagement across multiple levels (Table 5.2). Together they exhibit diverse approaches for information exchange, either from the international to national level or generating and sharing empirical information and knowledge from within Vietnam. But it is also apparent that these modes of information exchange have been performative rather than transformative (Westley et al., 2013). That is, the government has provided the space for NGOs to gather and share information, and NGOs have invested considerable resources into these information related activities. However, contrary to the adaptive management literature, which stresses the importance of open lines of knowledge sharing (see Plummer and FitzGibbon, 2004a), there has not been any meaningful integration of different forms of indigenous and scientific knowledge in either customary or statutory laws related to SUFs; a point reiterated by respondents in the national survey. Similarly, the four NGOs demonstrate a diversity of ways in which they attempt to build common visions and a set of goals around (SUF) co-management, including sharing international and domestic experiences. Supporting the findings of others, these NGOs do appear to play an effective role in linking the grassroots level with resources and information to many governmental programmes (Nørlund, 2007). But while they have been able to engage governments at all levels - from individual SUFs to the national level - officials have been reticent in making any changes to SUF goals or policy because of an unwillingness to devolve any decision making control away from the state.

The ability of the four NGOs to engage in conflict resolution appears to be even more challenging. The case studies and survey results indicate a pre-emptive mode of conflict resolution through relationship management and network building, by providing training to local level communities and rangers. Building on the administrative mode of comanagement in Vietnam (KimDung et al., 2013), the networks appear to be oriented towards collaboration with government related actors, such as the police, military, state sponsored civil organisations (cf. Thayer, 2009; Wischermann, 2010). These NGOs have 
been less able to extend collaboration to private sectors, scientists, and independent NGOs because SUF MBs engagements remain firmly oriented to these state networks, only marginally including private actors of different kinds. Nevertheless, those NGOs focused at the local scale appear to have more success in influencing SUF leadership and coordinating a wider group of locally based actors (see also Thayer, 2009). Overall, however, conflict resolution appears to mean fitting into the ongoing work plans of central and provincial level governmental agencies, rather than mediating between different sides and interests of a conflict.

Perhaps the most sensitive and least well developed bridging function for the four NGOs, is their role in community empowerment. NGOs appear to be constrained in their attempts to strengthen community empowerment because of shortcomings in capacity and resources, as well as limitations imposed by the state in engaging in what is deemed to be a political activity. The work that the NGOs are able to carry out focuses on facilitating participation at provincial and national conferences and meetings. As Lux and Straussman (2004) point out, this kind of civil participation in Vietnam cannot be compared to the more liberal forms of civic action in other countries. Participation in Vietnamese comanagement is instead state sanctioned and supported, especially by CPCs at commune levels in accordance with the Grass-roots Democracy Ordinance 2007 (Vietnam National Assembly, 2007; Coe, 2013). The consequence is that communities are able to voice concern, but are not able to make demands on how these concerns are dealt with beyond what Coe (2015) refers to as the 'rightful resistance' of holding the government accountable to its own purported values. Engagement with marginalised communities (either ethnically or economically) also appears difficult because of a lack of NGO resources, but also because these communities exist outside of the networks controlled by local state.

The limitations of these NGOs to fulfil the functions of bridging organisations means that it is unlikely that NGOs are able to overcome the administrative mode of Vietnamese comanagement in the near future. However, the fulfilment of bridging roles in the future also appears dependent on at least two key factors. First, some form of international connection appears to provide increased flows of information, best-practice experiences and financial resources, as well as some political room for manoeuvre to engage in both co-management policy and implementation. Vietnamese NGOs and civic organisations like PanNature, MCD and the VNPPA may be fundamentally constrained from fulfilling bridging functions given their close association with the state (Hannah, 2009; Wischermann, 2011). Similarly, international NGOs are likely to remain under strong restrictions from the central government and are hampered in their effective functioning as bridging organizations by their limited knowledge of and access to the Vietnamese political/state system, a key precondition under Vietnamese circumstances. Nevertheless, access to international resources appears to better enable these NGOs to fulfil a bridging role. While the capacity 
and function of Vietnamese and international NGOs is noted as gradually closing, there remain clear differences in terms of political access, trust and effectiveness (Lux and Strausmann, 2004; Wischermann, 2010; Fabres, 2011). How these differences influence the type and extent of bridging functions performed by these NGOs both in and beyond Vietnam need further research.

Second, the results indicate that a 'staged strategy' by NGOs might better enable NGOs to function in the Vietnamese context: first focusing on maintaining a degree of pragmatism in less political/controversial activities such as information exchange, to be followed later by engagement in more sensitive or politicized areas like community empowerment; as long as the Party's central authority is not challenged (Marsten, 2012). Doing so addresses key concerns around the high degree of performativity exhibited by NGOs in Vietnam which are directly restricted by centralised political control (Wischermann, 2010; Fabres, 2011). In this way the four bridging functions might be seen as a set of sequential steps that form a (albeit likely long-term) strategy to engage the government in more inclusive comanagement and progress beyond administrative forms of co-management in SUFs. Starting with the first two (less sensitive) dimensions of bridging organisations of knowledge brokering and visioning before moving on to networking and empowerment may prove to be more effective for NGOs in Vietnam. This in turn opens up a new perspective on bridging functions, which are assumed to be performed simultaneous rather than sequential in the wider literature on co-management (e.g. Berkes, 2009; Crona and Parker, 2012; Rathwell et al., 2015). By adopting a sequential strategy for employing these bridging functions may enable NGOs to be more transformative in the sense of balancing both local interventions aimed at immediate issues, with longer term adaptive and precautionary policy change at the national level.

These findings hold implications for understanding the role how bridging organisations operate in centralised 'mono-organisational' states such as Vietnam (Wischermann, 2010) but also other states such as China, Laos and to a lesser extent Cambodia and Myanmar. Understanding the extent to which bridging functions can be implemented, by which types of NGOs and in what order, holds wider theoretical implications for innovations in comanagement arrangements where bridging between societal and state actors is constrained by strong political oversight. This is important because co-management has seen a considerable development in contexts of more democratized states (e.g. Pahl-Wostl et al., 2007; Rathwell and Peterson, 2012). While co-management has been tested and developed in developing countries the specific differences in political structure have rarely been taken into consideration. If institutional change is the ultimately outcome, with adaptive processes institutionalized across multiple levels, then the bridging functions of NGOs need to be considered in these contexts. 


\section{Conclusion}

The continued administrative role of the Vietnamese state in SUF management means that both profit and not-for-profit private organizations remain at the periphery. Our conclusion therefore is that NGOs are only likely to play a limited role as bridging organisations under present conditions. As NGOs in Vietnam only work through negotiation, information and education within the provided legal bounds, and should refrain from more sensitive and politicized issues of conflict resolution and community empowerment, they remain weak in transforming the (administrative) SUF co-management arrangement. In addition distrust among SUF MBs and local state officials in the capacity of local resource users has also strengthened SUF administrative co-management, and constrained the bridging work of NGOs and institutional innovations. Both aspects hinder Vietnamese and international NGOs to act as full bridging organizations and thus innovate SUF administrative co-management.

The structural barriers to change in so called 'mono-organisational' socialist countries such as Vietnam indicate a need to rethink the bridging functions of NGOs in overcoming the limitations of administrative forms of co-management. Greater consideration needs to be given to how NGOs in Vietnam can create more adaptive forms of natural resource management, given the fact that the SUF system is centrally controlled and western democratic dichotomies of state and civil society do not appear to hold. Under such conditions it is necessary to further elaborate how NGO-state relations can be brought beyond a performative mode of engagement that is currently seen in Vietnam. What role then is there for international NGOs and donors, and how would a sequential, step-wise approach along the four dimensions of bridging organization be useful? To answer this question, further analysis of the attitudes and practices of different kinds of Vietnamese and international NGOs in promoting co-management should be combined with studies of NGO-state relations in natural resource management in other state-dominated Asian societies such as China and Laos.

Finally, our study feeds into the wider literature on bridging organizations in adaptive comanagement. In adaptive co-management of natural resources, but perhaps even in wider sectors of science policy interface, bridging organizations can and do play different roles in different countries, depending on among others the level of economic development and the degree of independent civil society development. NGOs are not everywhere well-placed to facilitate collaboration across organizational levels and knowledge systems and strengthen social capital and capacity of local communities. In developing countries with a less wellorganized and independent civil society NGOs have clearly less political space, resources and possibility to fulfil all four functions of bridging organizations. Hence the theory of bridging organizations needs to better engage with a wider diversity of political contexts in which co-management is being implemented. 


\section{Chapter 6 \\ DISCUSSION AND CONCLUSION}

\section{Introduction}

Vietnam's national Special Use Forest system was established to promote national nature and biodiversity conservation. However, it is argued that the SUF system has malfunctioned because of the way in which it is managed across the country (McElwee, 2016). The deficiencies of the SUF system have been listed as a lack of property rights, weak engagement with supporting local livelihood in around management areas and the government's strong reluctance to manage SUFs with meaningful collaboration with other societal actors (McElwee, 2004; Sikor and Phuc, 2011; McElwee, 2016). To fix this system, NGOs and scholars alike have argued for a shift to co-management to ensure that these structural limitations of state-led SUF management are overcome (IUCN, 2010; Sikor and Phuc, 2011). Following these calls over the last decade, co-management has been introduced into Vietnamese SUFs management with an originally normative emphasis on finding 'win-win' solutions that could link conservation and development activities. In particular the government has seen co-management as a means of boosting the role and function of the SUF system to support the implementation of the Comprehensive Development and Hunger Eradication and Poverty Reduction Strategy, in addition to more mainstream policies associated with national industrialization and modernization (Sunderlin and $\mathrm{Ba}, 2005)$. At first glance, it can be concluded that co-management has progressed at a gradual pace since 2000, towards a more people centric mode of national SUF management.

As argued throughout this thesis, however, the degree to which co-management has been included into the national SUF programme has to be viewed from multiple scales, and based on grounded empirical evidence, rather than policy statements alone. International experience with natural resource co-management, in large part based in liberal democracies in North America and Europe (e.g. Pinkerton, 1994; Jentoft and McCay, 1995; Kendrick, 2003; Pahl-Wost and Hare, 2004; Plummer and FitzGibbon, 2006; Berkes, 2009; Baird, Plummer et al., 2016), demonstrates the often embedded nature of 'success', including a thick understanding of the socio-economic and political context within which interventions are based. Based on these same studies it is clear that decentralization is a key linchpin to co-management because it directly relates to the mobilization and welfare of those local communities at the centre of natural resource use conflict (Campbell and Vainio-Mattila, 2003; Borrini-Feyerabend, Pimbert et al., 2004). However, the results presented in the 
preceding chapters also demonstrate the importance of understanding decentralization as a political rather than managerial process. As outlined by Pomeroy (1995), the planning and implementation of a co-management system " ... require the development of new legal, administrative and institutional arrangements at both national and community levels to complement contemporary political, economic, social and cultural structures" (Pomeroy, 1995, p. 143). In other words, considering the political dimension of the design of comanagement is a "necessary prerequisite without which ... initiatives are unlikely to succeed” (Macfadyen, Cacaud et al., 2005, p. iv). By taking the politics of co-management as a starting point, this thesis has questioned whether co-management arrangements for nature protection in a centralized state like Vietnam will look similar to co-management in marketoriented liberal democracies.

Pluralism, Communication and Negotiation, Social-learning, Transactive decision-making and Shared actions and/or Commitments are prominent dimensions of co-management (Plummer and FitzGibbon, 2004a). Pluralism relates to the inclusion of various interests and/or inputs in the process of co-management. Communication and Negotiation is a key dimension of co-management which can be enabled through information exchange and feedback in order to gain consensus and common understanding amongst stakeholders. Social learning refers to on-going knowledge creation by sharing values, jointly implementing actions, reflecting upon feedback, and incorporating knowledge generated from a given experience into new collective practices of resource management. Transactive decision-making focuses on the process through which information from multiple types of knowledge contribute to more equitable and efficient co-management processes. And Shared actions and/or commitments refer to the willingness of all actors to undertake joint activities under collaborative forms of management. Generally, these dimensions of comanagement illustrate the inclusion and equitable interactions between actors at multi levels and scales, the orientation toward power and responsibility sharing and the upgrading of local positions in the co-management arrangement (Plummer and FitzGibbon, 2004a; Armitage, Marschke et al., 2008; Bene, Belal et al., 2009). In other words, co-management exercises a real process of devolution and decentralisation (Bene, Belal et al., 2009). Additionally, in most interpretations of co-management, local governance is much more than local government. Co-management comes with a call "for a government to decentralise, delegate or devolve authority and responsibilities in several branches of social life to the lowest possible level with capacity to take responsibility for the relevant tasks" (Borrini-Feyerabend, Pimbert et al., 2004, p. 356). According to various scholars, comanagement is also regarded as a base for gaining a capacity of adaptability of a socialecological system in response to changing conditions and disturbance events (Harkes, 2006; Lebel, Anderies et al., 2006; Armitage, Marschke et al., 2008; Berkes, 2009). In order to become adaptive, a co-management arrangement requires openness to learning in order to accept the inevitability of change, and achieve the ability to treat interventions as 
experiments. Learning develops relationships among the actors that constitute comanagement processes (Armitage, Marschke et al., 2008). Learning and adaptive comanagement altogether are critical for cross-scale linkages or linking functions (horizontally and vertically) (Harkes, 2006; Wilson, Ahmed et al., 2006; Plummer and Armitage, 2007; Armitage, Marschke et al., 2008). By linking iterative learning and knowledge generation with power-sharing, adaptive co-management provides a potential solution to resolving complex social-ecological problems (Berkes, 2009; Butler, Young et al.; 2015). With high adaptability, actors of the arrangement have the capacity to reorganize the system within its desired states (Folke, Hahn et al., 2005; Lebel, Anderies et al., 2006; Plummer and Armitage, 2007). Besides the above theoretical perspectives, to qualitatively measure the degree in which power is shared between government and local people along the five characteristics of co-managements we also included a scale of co-management based on Sen and Nielsen's classification (1996), ranging from government-based management system to a community-led co-management (Sen and Nielsen, 1996).

With these conceptual notions this thesis addresses the following two research questions:

1. How can the current form of co-management in Vietnam's national system of Special Use Forests governance be characterised?

2. How and to what extent can a more adaptive form of SUF co-management be developed and implemented in Vietnam's forest management?

To find answers to these research questions the previous chapters have examined the types and extent of co-management in Vietnamese SUFs from national level policy to locally specific case studies. In doing so the thesis has drawn together an analysis that uses multiple methods to triangulate evidence across multiple levels, including a wide range of public and private actors. Such an approach makes a valuable contribution to the study of comanagement because it moves beyond the common case study approach to position local manifestations of co-management in their wider national political economic context. Chapter 2 focused on the broad legal and policy framework within which SUF comanagement exists, focusing on the degree to which this framework can allow for a decentralised form of co-management that is both responsive and adaptive to the local diversity inherent to the national SUF system. Chapter 3 then examined the extent to which SUFs across the country have taken up key elements of adaptive co-management. The final two empirical chapters then investigated the form and dimensions of power relations that exist between state and non-state actors in both vertical and horizontal dimensions and the role that NGOs in particular play in bridging local and state interests and goals. 
In this final chapter, the main findings from this research are reviewed and discussed in terms of its contributions to theoretical perspectives of co-management, especially linking with international practices of co-management arrangements. These altogether lead to the conclusion that co-management in the context of the centralised state of Vietnam is exercised in its own Vietnamese "style", which has been labelled "administrative comanagement". The next section concludes on the key dimensions of this Vietnamese style of co-management. Subsequently, the possibilities for overcoming this administrative comanagement in Vietnam are outlined in section 3. Section four relates these conclusions on Vietnam's system of co-management on SUFs to the wider perspective on co-management in other 'mono-organizational' states. The last section formulates recommendations based on this thesis.

\section{Key dimensions of Vietnamese co-management}

\subsection{Moving beyond an 'instructive mode' of SUF co-management}

Co-management relates to various forms of partnership between public and private actors that defines a degree of shared responsibility for functions and entitlements related to the management of natural resources (Carlsson and Berkes, 2005; Ratner, Oh et al., 2012). There is no one model or blue-print for co-management; instead academic scholarship has focused on the degree to which co-management arrangements can create adaptive responses from the parties involved to deal with different rates of environmental and social change (Folke, Carpenter et al., 2002; Armitage, Plummer et al., 2008; Plummer, 2013). A considerable amount of attention has been given to the institutional design of comanagement arrangements but few studies have undertaken in depth investigations of the degree to which state policy and legislation enable or constrain the emergence and type/form of co-management. Even less attention has been given to the specific challenges that centralized 'mono-organizational' socialist states such as Vietnam (Thayer, 1995) face in transitioning to a collaborative mode of natural resources management.

The first finding of this thesis is that the Vietnamese government sets a clear intention in policy and law to actively diversify the number and type of actors engaged in SUF management. Consistent throughout the review of policy and legal documents reviewed in chapter 2 there is a clear focus on the participation of local resource users, reflecting the wider political rhetoric of Vietnamese socialism as shown in its very popular slogan "the people know, the people discuss, the people do and the people monitor" (Bui Hai Thiem, 2015; Hoang Van Nghia, 2015). However, what also emerged from the review is a poor coverage of legitimation by the state of the right of resource users to organise and enforce SUF co-management. What is notably absent is any real commitment to the 
decentralisation of SUF management through for example the recognition of communitybased SUF management arrangements, or an allocation of management functions to private actors beyond those either within or close to the state. In contradiction to the wider literature on co-management, which stresses the importance of decentralised and locally adaptive forms of co-management (Borrini-Feyerabend, Pimbert et al., 2004; Ribot, Agrawal et al., 2006; Armitage, Plummer et al., 2009; Berkes, 2009; Berkes, 2010; Cronkleton, Pulhin et al., 2012), the participation of any other actors in SUF arrangement remains centralised and steered by governmental agencies or political organisations such as the Commune People's Committees. Similarly, two-way communication and negotiation among SUF actors for a shared understandings and vision is only weakly supported by the state. Effective communication and negotiation on SUFs is clearly delegated to the Vietnam Fatherland Fronts. However it is difficult to find any specific SUF legal text that explicitly outlines how 'two-way' interactions with non-state actors, that would conform to international views of co-management (Borrini-Feyerabend, Pimbert et al., 2004; Plummer and FitzGibbon, 2004a; Cronkleton, Pulhin et al., 2012), should be organized and take place in SUF management. Commune People's Councils, Communes, and the Commune Vietnam Fatherland Fronts are required to assure processes of two-ways communication and negotiation from the grassroots to higher governmental levels.

In terms of social learning, some administrative support for co-management arrangements are provided in policy and legislation, such as human and financial resources. However, crucial requirements and lessons for co-management arrangements to enable greater and more equal interactions among actors, and which ultimately lead to gradual improvements in conservation, are not outlined in the legal framework. This means that while there is an intention for on-going knowledge creation, as well as the incorporation of this knowledge into new collective practices of resource management (Davidson-Hunt and O'Flaherty, 2007; Berkes 2009), it remains unclear how the responsibilities for achieving such learning is operationalised by the state. Finally, while incentives have been mandated for SUF participatory management, market approaches such as Payment for Environmental Services PES and ecotourism have not been given a clear set of rules within which investments can been made in SUFs. And where they have been set up, there is no clear mechanism for benefit sharing with local people surrounding SUFs. The overall conclusion is that the government keep controls over SUF ownership and the resource rights, while local people are seen as a form of human resource at the disposal of the state to utilize for management and conservation activities. This finding is similar to those of other studies in Vietnam (e.g. Sikor, 2001; Sunderlin, 2006; Thanh and Sikor, 2006; Sikor and Thanh, 2007; McElwee, 2012; To, Dressler et al., 2012). 
So while there is a clear intention for the development of SUF co-management, it is biased towards what has been labelled by Sen and Nielsen (1996) an 'instructive model', characterised by only minimal exchange of information between government and users. A series of key observations can be drawn from the legal and policy review that underlie the development of co-management. First, it illustrates the tension between decentralization and centralization of SUF management. The government may be willing to call for more participation, but it appears reluctant to delegate significant authority to manage natural resources to local communities and organisations (Pomeroy, 1995). Second, the overlapping mandated responsibilities of governmental agencies creates a difference between the rhetoric and reality in biodiversity conservation and environmental protection. The lack of clarity around property rights has undermined attempts by management boards to engage communities in co-management (Nguyen Hai Van, 2014). According to Cronkleton (2012), the way partial devolution of rights take place creates a faulty co-management system and excludes many community groups from participating. Additionally, "state forest bureaucracies are often rigid or unwilling to evaluate or adjust regulatory frameworks, but flexibility is necessary to practice co-management locally. As a result, "balancing the need to address local contexts without dissipating policy frameworks into myriad locally specific rules is a challenge" (Cronkleton, Pulhin et al., 2012, p. 101). However, "local institutions have better knowledge of local needs, and, when endowed with powers, are more likely to respond to local aspirations" and "more easily held accountable by local populations"; and at the central of aspirations they need a say in their own affairs (Ribot, Agrawal et al., 2006, p. 1865).

What this result shows is that for the Vietnamese government to move beyond an instructive mode of co-management the first step will be the revision of the legal and policy framework. Considering co-management as a 'process', as outlined by Plummer and Baird (2013), means that the refinement of this legal and policy framework could be taken up through a process of co-creation. This would require the establishment of a collaborative process through which a clearer delineation of rights and responsibilities around SUFs are set out in policy and law. In line with co-management in other parts of the world, one specific area of development could be a framework for the inclusion of customary laws into SUF policy and legislation because "co-management is not merely about resources, it is mostly about managing relationships" (Berkes, 2009, p. 1692). People whose livelihoods are affected by resource management should have a say in management measures to increase the legitimacy and compliance of the resource management (Davidson-Hunt and O'Flaherty, 2007; Berkes, 2009). A second area that this finding also highlights is the need for an improved framework for communication and negotiation with local resource users in which the right of dialogue and the accountability of government organisations are more focused. "In a nutshell, "participatory management needs participatory roots" such as some measure of effective dialogue, discussion of issues and participatory democracy internal to 
all relevant social actors" (Borrini-Feyerabend, Pimbert et al., 2004, p. 175). A better communication and mutual learning through treating local/indigenous people as equal participants in processes of co-management also theoretically lead to creating more adaptiveness of the system (Armitage, Marschke et al., 2008; Watson, 2013). Moreover, it should also change the current practice that local authorities tend to be accountable upward to the central authorities of the state rather than accountable horizontally or downward in natural resource management (Lebel, Anderies et al., 2006).

\subsection{Administrative co-management as a brand of Vietnamese SUF co-management}

A key tenet of adaptive co-management is that specific arrangements are required to deal with the variety of biophysical and social conditions apparent in any given situation. Ambitions for more adaptive forms of management in Vietnamese SUFs are widely stated, largely in response to a central issue in the current makeup of the national SUF system. That is, while the size and number of SUFs has increased over the last two decades, the biodiversity within these areas continues to decline (ICEM, 2003; VEPA, 2007; MONRE, 2011a). It is therefore salient to look at the potential for a greater decentralization of state authority and increased public involvement in order to create locally adaptive comanagement arrangements rather than prescriptive forms of (near) one-size-fits-all modes of co-management (see Armitage et al., 2009; Marin and Berkes, 2010). Against this background this thesis assessed the extent to which SUFs - in the real world - are, if at all, shifting from conventional government-based management to decentralised and adaptive forms of co-management.

Based on the results of the national survey presented in Chapter 3, the second result of this thesis is that the type of actual co-management varies little between the four different categories of SUFs (national parks, nature reserves, habitat and species reserves, and landscape protected areas). In general, SUF management arrangements appears to be equivalent to a "cooperative" form of co-management as defined by Sen and Nielsen (1996). This extends beyond the first result of the thesis, which indicates that policy and the legal framework around SUFs would only allow state controlled or 'instructive' forms of co-management. However, what the results also show is that within this co-operative classification, a particular Vietnamese "style" of co-management is observed. Based again on the dimensions of adaptive co-management outlined by Plummer and FitzGibbon (2004; 2006), this Vietnamese style can be labelled as 'administrative' in nature and defined as follows. First, despite a degree of pluralism being evident, the stakeholders involved are predominantly part of the state system. Second, communication and negotiation is based on instruction rather than transactive decision making - something that is supported in policy and legislation (see above). Third, the one-way nature of instruction leads to very little in the way of what could be labelled social learning - meaning also that higher level authorities 
also do not respond to or adapt policy and legislation in response to management boards, for instance. Finally, any form of shared action is hindered by the weak recognition of local people's rights, historical values and indigenous customs, and a lack of incentive-based policies to motivate stakeholders to collaborate with SUFs.

The essence of administrative Vietnamese co-management is therefore that final decisionmaking power on management remains strongly in the hands of the state in general and the provincial government in particular. Conversely local people are not formally involved in policy formulation around SUFs but, in support of the first result outlined above, relegated to a form of labour in conservation and management activities. Benefit sharing is only revealed in a few SUFs in which local people can harvest some kinds of non-timber forest products. But perhaps most characteristic of administrative co-management is the position of local people, who remain in general terms a threat rather than a collaborator in natural resource management.

Administrative co-management may be characteristic of not only Vietnam, but also wider aspirations of collaborative natural resource management in centralised states. Indeed, there is a relative dearth of research that covers such forms of natural resource management in these centralised states (with some exceptions, see Arthur, 2005; Chen, Shivakoti et al., 2012; Ting, Shivakoti et al., 2012). Instead the literature on (adaptive) co-management has an analytical and normative bias to liberal economies, where individual and even collective property rights are more clearly defined and enforced, and stakeholder deliberation is largely mainstreamed (Essen and Hansen, 2015). The first and second results of the thesis therefore demonstrate some fundamental contradictions to the essential ideals of comanagement, which emphasise partnerships between government agencies, local communities and resource users, non-governmental organisations and other stakeholders, in order to negotiate, agree upon, guarantee and implement a fair share of management functions, benefits and responsibilities for the management of resources (BorriniFeyerabend, Pimbert et al., 2004). The question remains what the unequal power distribution that underlies administrative co-management means for changes in the future to aspirations to Vietnamese co-management.

\subsection{Towards a networked vision of co-management}

Under the current SUF management, one of the major challenges for moving beyond an administrative mode of co-management is to promote flexibility and local adaptability through SUF management boards within the overall still rigid structure of vertical state networks. Examining this challenge leads to the third result of the thesis. Using a critical institutional perspective (based on Ratner et al., 2012), case study research demonstrated the importance of vertical linkages in the administrative co-management arrangement to improve the capacity and responsibilities of SUF Management Boards and to facilitate more 
participative co-management. While this vertical relationship opens up new and potentially constructive ways to think about the specific role of central state actors, in addition to those operating closer to resource users (such as management boards), it also demonstrates how state actors co-determine the development of community capacities to engage in cooperative forms of conservation in state-run SUFs.

The four cases investigated - Cu Lao Cham, Xuan Thuy, Nui Chua, Khau Ca - provide details on the extent to which SUF management is yet to fully shift from a centralised statebased model of management to a decentralised form of adaptive of co-management. Although a diversity of actors are legitimised by the state to engage in co-management across these four cases, their contribution to the day-to-day co-management activities is limited by a fundamentally unequal division of political and fiscal control, mainly in the hands of the Provincial People's Committee. Strengthening the first two results of the thesis, the cases demonstrate the reliance of SUF management boards on the allocative power of vertically 'higher' actors to organise and operationalise horizontal relations (e.g. Plummer and FitzGibbon, 2006; Marín et al., 2012). But the results from these case comparisons also demonstrate that if participative mechanisms are not put in place by these vertically dominant state actors then local actors are stifled in their goals of creating 'horizontal' co-management relations.

Although more evidence would be needed to make a definitive conclusion, the cases also appear to show that when the Provincial People's Committee is bypassed there is more scope for 'horizontal' co-management. What this result indicates is the particularly dominant role of the Provincial People's Committee over the capacity of SUF management boards to fulfil any form of co-management. The Provincial People's Committees hold executive decision making power and control the financial resources on which SUFs rely. If a Provincial People's Committee holds nature conservation as a priority, and is willing to devolve power to others in the co-management network, a participative and problem solving form of co-management easily emerges. However, if the Provincial People's Committee does not prioritize conservation, or community engagement, their central role and power can block the involvement of other (vertical and horizontal) actors, and in doing so undermine the resolution of common interests, benefit sharing and joint decision making. It therefore appears that the Provincial People's Committee is the key actor in the emergence of the 'administrative' mode of co-management observed in Vietnam.

This third result of the thesis also opens up a seeming contradiction when considering how to overcome this dominant and apparently counterproductive role the Provincial People's Committee plays in SUF co-management. While the central government has sought to decentralize control over SUFs to Provincial authorities, it seems that what has emerged instead is a level of control that is not uniform in its conservation goals across the country. 
To overcome this situation it appears that one of two changes are needed. First, bypass the Provincial People's Committee to ensure more direct control by the central government, with second, a view to institute a balance between creating a stronger vision for comanagement at the level of SUFs and allowing enough autonomy of SUF management boards to implement activities and engage with local communities. But importantly, the result also shows that the capacity of management boards to perform their mandated functions improves when they work with international organisations and when they introduce benefit sharing mechanisms for local communities. Such external influences do not equate to a weakening of state power (see Gainsborough, 2007; Wischermann, 2011 for reviews on this debate). On the contrary, it is still the state that facilitates and conditions both vertical and horizontal collaborations of SUF management boards, but in a way that promotes rather than restricts collaboration with non-state actors.

\subsection{Creating space for NGOs as bridging actors}

The fourth result of the thesis indicates that NGOs can play an important role in reforming administrative co-management in Vietnam by developing capacities as bridging actors. By supporting SUF management boards and by facilitating ongoing relationships with local communities and the government, NGOs can 'bridge' collaboration across levels, sectors and knowledge systems.

Evidence from a national survey and four NGO case studies indicate that NGOs can fulfil four bridging roles, albeit currently to varying levels of success. First, NGOs adopt diverse approaches for information and knowledge exchange. However, the results also indicate that until now the specific modes of information exchange have been performative rather than transformative due to a lack of mandated space provided by the government. Second, NGOs play an important role in building a common vision around SUF co-management based on both international and domestic experiences. At the same time, it appears that officials are reticent to make any changes to SUF policy because of an unwillingness to devolve any decision making control away from the state as 'best practice' experiences would dictate. Third, NGOs can be a neutral arbiter of partnerships between private sectors, scientists, and other NGOs. But further success in this role would require a shift away from the singular focus on state (controlled) networks, as illustrated in chapter 4. Fourth, NGOs demonstrate they have an important role in strengthening community empowerment by directly supporting capacity building and providing human and financial resources to communities. Yet this role is also currently constrained in Vietnam given that this bridging function is often deemed as a political activity by the state and therefore restricted. NGOs are only able to focus on facilitating participation at provincial and national conferences and meetings where local communities are able to voice concern, but are not able to make demands on how these concerns are dealt with beyond what Coe 
(2015) refers to as the "rightful resistance" of holding the government accountable to its own purported values.

These findings hold implications for understanding the role how bridging organisations operate in centralised 'mono-organisational' states such as Vietnam (Wischermann, 2010). Vietnamese NGOs may be fundamentally constrained from fulfilling bridging functions given their close association with the state. By the same token, international NGOs are likely to remain under strong restrictions from the central government and hampered in their effective functioning as bridging organizations by their limited knowledge of and access to the Vietnamese political/state system. The gap between the capacity and current function of both Vietnamese and international NGOs appears to be gradually closing, yet there remain clear barriers to fulfilling meaningful bridging roles (see also Zingerli, 2005; Thayer, 2009). To overcome these barriers, and with them advancing an administrative mode of Vietnamese co-management, two key factors appears necessary. First, a greater level of international collaboration appears necessary to provide increased flows of information, best-practice experiences and financial resources, as well as some political room for manoeuvre to engage in both co-management policy and implementation. Second, a 'staged strategy' by NGOs appears necessary: focusing on maintaining a degree of pragmatism in less political/controversial activities such as information exchange, and then followed up by engagement in more sensitive or politicized areas like community empowerment; as long as the Party's central authority is not challenged (Marsten, 2012). This in turn opens up a new perspective on bridging functions, which are assumed to be performed simultaneous rather than in sequential orders in the wider literature on comanagement.

In sum, understanding the extent to which bridging functions can be implemented, by which types of NGOs and in what order, holds wider theoretical implications for innovations in co-management arrangements where bridging between societal and state actors is constrained by strong political oversight. This is important because comanagement has seen a considerable development in contexts of more democratized states (e.g. Pahl-Wost, Sendzimir et al., 2007; Pahl-Wostl, Craps et al., 2007; Rathwell and Peterson, 2012). While co-management has been tested and developed in developing countries, the specific differences in their political structure compared to advanced liberal democracies have rarely been taken into consideration. If institutional change is the ultimately outcome, with adaptive processes institutionalized across multiple levels, then the bridging functions of NGOs need to be considered in context. 


\section{Conditions for overcoming 'administrative co-management'}

These key results of the thesis outlined above identify and define administrative comanagement in Vietnamese SUFs. In doing so the thesis points to the specific challenges of collaborative forms of natural resource management in centralized states. The results also show that while ambitions for collaborative management are derived from what is widely seen as an international imperative or 'best practice', its translation into Vietnam could be considered partial at best. Does this mean that there is little hope for the development of adaptive forms of co-management in the context of centralized 'mono-organisational' states? The answer drawn from the results above should be: 'not necessarily'. The results clearly indicate that co-management is practiced in Vietnam, but at a level where state imperatives remain key to the specific arrangements that are implemented at the level of SUFs. More specifically, the results also show that an administrative co-management is a likely outcome when a combination of three key principles of adaptive co-management are not addressed: pluralism, accountability and incentivisation. Working within the context of a centralized state does therefore not mean that adaptive forms of collaborative management are not possible. As I argue in the rest of this chapter, these three inter-related principles (see Figure 6.1) offer insights into how measures can be taken to ensure that an administrative co-management regime can be made more adaptive to local conditions and therefore more effective in instituting conservation measures in SUFs.

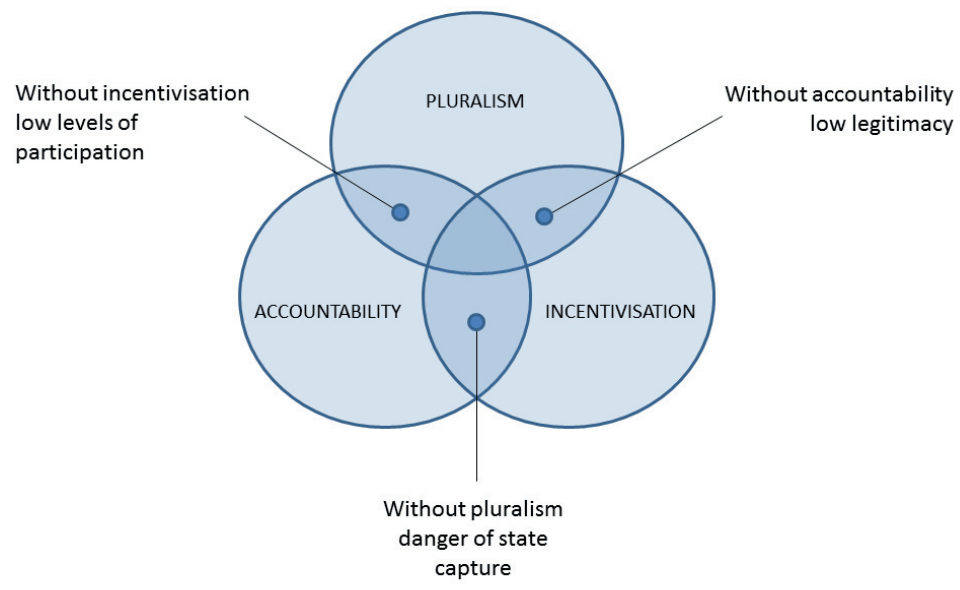

Figure 6.1. Relational framework for reforming administrative co-management in centralised mono-organisational states 


\subsection{Pluralism}

Pluralism is seen as a key component for increasing legitimacy as well as effectiveness in comanagement (Plummer and FitzGibbon, 2004a; Berkes, 2009). The major results of the thesis outlined above indicate that pluralism is restricted under the administrative mode of co-management employed by the Vietnamese state. As indicated in Figure 6.1, pluralism is also the first principles that needs to be reformed, but not in isolation from accountability and incentivisation. Here I first address a strategy for dealing with pluralism in and of itself before moving on the other two related principles.

Although stated as such, pluralism is not per se a limiting factor in Vietnamese administrative co-management: there is considerable policy and legislation that stipulates that different state and non-state actors should be involved in natural resource management in general, and SUF management in particular. Instead, what is limiting effectiveness is active participation in Vietnamese SUFs, meaning that the inclusion of non-state actors (and indeed in many cases state actors) is largely performative. This means that while non-state actors are given access to decision making spaces and processes they do not, by design, have influence over the decisions being made (cf. Persha and Andersson, 2014; Pham, Gregorio et al., 2014; Phuc, Westen et al., 2014). If co-management is to emerge as a means of promoting shared responsibility and authority, then pluralism needs to be both actively participatory while at the same time moving beyond the state. Based on the results of this thesis, I argue that an active mode of pluralism and participation can be realized if two things are taken up in the reform of co-management. First, existing policy and legislation needs to allow for the extension of the kinds of horizontal networks outlined in Chapter 4, and second, a clearer mandate for NGOs is needed to allow them to not only attend national fora, but take a state sanctioned 'bridging role' in the development of comanagement networks around SUFs.

What then would pluralism look like in a centralised mono-organisational state like Vietnam? To answer this question, it is necessary to consider new modes of public participation which are steered by the Vietnamese state. It is clear from the results that Vietnamese administrative co-management allows for non-state involvement, but it appears that the direct involvement of these actors is limited by the attempts by state actors to maintain decision making control. A new mandate for non-state actors to provide support in the form of knowledge and experiences around nature conservation techniques and finance could be a starting point for such reform (Pomeroy, McConney et al., 2004). Similar arrangements have been established in Vietnam in the case of non-state forms of regulation for forestry and aquaculture certification (e.g. Ha and Bush, 2010; Bowers, Eastin et al.; 2012). There is no reason to think that a similarly facilitating role of the state could be established for co-management arrangements in nature protection. Indeed, the engagement 
of both domestic and international non-state actors is already evident in many SUFs, albeit with highly variable levels of participation in decision making. Reflecting the findings of chapters 4 and 5, attention could initially be given to politically less sensitive issues such as encouraging activities that are focused on local livelihood development, the integration of indigenous and scientific knowledge. However, over time, attention could also be given to institutional changes that enable devolution of co-management beyond the state.

Reforming the administrative co-management regime would also require a clearer mandate for Vietnamese and international NGOs alike to fulfil a bridging role. As outlined in chapters 3 and 5, SUF management based solely on the state in Vietnam is infeasible due to the lack of finance and human resources. By partnering with NGOs the state could extend the current administrative co-management regime to delegate specific functions to them, such as data collection, monitoring and enforcement (see also KimDung, Bush et al., 2016a; KimDung, Bush et al., 2016b). If an active form of pluralism can be balanced with continued state guidance, local empowerment may also ensue to an extent that would allow for state control over a national agenda, but at the same time provide space for adaptive decision making under the guidance of bridging NGOs. By using these NGOs as a legitimate 'third party' or arbiter of co-management relations the role of non-state actors could be more clearly defined and utilized to reach state objectives (see Carlsson and Berkes, 2005; Redpath, Young et al., 2013). For example, private actors could be engaged to increase legally economic activities relating to nature conservation and local livelihood development, and local people could be given monitored levels of resource extraction to support local livelihoods while at the same time engaging them in long term plans for nature conservation activities. Under a reformed administrative co-management regime decision making would ultimately remain with SUF management boards, but be supported by these NGOs who could provide a basis for more legitimate management measures, and even increase rule compliance. Reflecting Pomeroy (1995) and McBeath and Rosenberg (2006), if successful, the current administrative co-management regime could be made more accountable to resource users and their needs, as well as better able to consider local complexities and uncertainties. Therefore, it would help to improve compliance to regulations, provide more locally relevant management plans, reduce poverty through diversifying economic activities and community participation.

\subsection{Accountability}

As outlined by Plummer (2013) co-management is not only advocated because it holds the potential to enhance the effectiveness of natural resource protection and management, but also because it brings stakeholder participation and therefore fairness, transparency, legitimacy and accountability to management (Jentoft, 2000). Based on the results of this thesis, I argue that it is accountability that requires the most attention when considering reforms of the current administrative co-management regime. 
The reason for focusing on accountability is because it is procedurally mandated in Vietnamese policy and legislation, as outlined in chapter 2, while also being a fundamental firmament to other governance principles of fairness, transparency and legitimacy (see Bennett and Dearden, 2014; Dore, 2014; Ho, Woodley et al., 2014). Furthermore, accountability represents the need to create clear procedural reforms in support of pluralism (see Figure 6.1). If non-state actors are to be meaningfully involved in SUF comanagement then, following Ho et al. 2014 and Marschke et al. 2014, open lines of communication, expectations and two-way sanctions between the state and those non-state actors need to be clearly stipulated and enforced. As argued by Sikor and Phuc (2011), high levels of accountability are key to avoiding potential conflicts of interests where a central state holds a monopoly on management tasks, including monitoring and enforcement and conflict resolution. Using the rise of institutionally supported corruption and what the authors term 'mutual degradation' of state agents responsible for forest resources, Sikor and Phuc (2011) argue for clearer lines of accountability. Based on the key results of the thesis, and drawing on the principles of adaptive co-management outlined by Plummer and FitzGibbon (2004a), I argue that accountability can be improved by ensuring greater degrees of transactive decision-making by non-state actors.

The results from the cross-case analysis in chapter 4 show that in some instances SUF management boards and non-state actors, such as multi-level governments, international organizations, and NGOs, have put in place arrangements to enhance communication and negotiation with local people. The specific case of Xuan Thuy national park is particularly insightful. There, local compliance with SUF regulations was supported by communicative structures that allowed the management board to understand the demands of local people. The result was a negotiated arrangement through which local people were granted limited access to SUF resources that ultimately led to lower levels of conflict and rule violation in and around the park. Reflecting on Figure 6.1, ensuring accountability within the existing administrative regime is essential for increasing trust in existing institutions. The case of Xuan Thuy illustrates that within this existing regime greater levels of communication and negotiation can be put in place that ensure greater accountability in both the design and ongoing management of the park. In line with Plummer and FitzGibbon (2004a) and Berkes (2009), enabling and instituting processes to exchange information and feedback to gain consensus and common understanding among state and non-state actors alike can equate to effective deliberation without radical changes to the central role of the state in SUF management.

Reflecting on the findings of chapter 4 and 5, such reforms could occur within the state and as such would crucially require both greater accountability of state actors at on-site level, such as Commune and District People's Committees, the SUF management boards and the 
implementation of the existing Democracy at Grass-Roots programme of the central government (Vietnam National Assembly, 2007). In addition, the Vietnam Fatherland Front need to be effectively exercised in accordance with what has been mandated in the Vietnamese legal framework at all levels. However, also following from chapter 4, the establishment of deliberative processes amongst state and non-state actors would ultimately involve the Provincial People's Committee and MARD, given their role in final decision making relating to SUF management. Reflecting the findings of others in Vietnam (Fritzen, 2006; Sunderlin, 2006; Clement and Amezaga, 2009; Coe 2013), some degree of devolution away from the central and provincial government is essential for a high level of trans-active decision making. As evidence from Xuan Thuy presented in chapter 4 shows, district level authorities can be effective in delivering a platform for not only deliberation but also support to economic activities relating to the SUF resource. The market development for Xuan Thuy clams is a case in point. At the same time Commune People's Committees have become active in planning, implementation and evaluation. If such mechanisms for transactive decision making are put in place in conjunction with greater and effective pluralism at the SUF level, greater accountability may be better supported.

It is also important to note, however, that - although deemed successful - models of communication and negotiation seen in Xuan Thuy do not address more fundamental points of conflict surrounding SUF management in Vietnam. The focus that procedural elements of co-management like communication and negotiation bring to natural resource conflicts does not address some of the more controversial points of conflict apparent in Vietnam (and other centralised states, see Ho, 2001; Vandergeest, 2003; Barney, 2009), such as property rights. But as McElwee (2016) notes, there are also questions as to whether greater communication and negotiation are geared to deal with such issues. Although crucial to the livelihoods of people during processes of SUF establishment, property rights are also state centric in Vietnam and perhaps beyond the remit of co-management arrangements to resolve in the short term. However, long-term changes to property rights, already a subject of debate in Vietnam (e.g. Clement and Amezaga, 2013; Kemper, Ha et al., 2013) would ultimately benefit from the engagement that greater accountability around 'conflict areas' like SUFs could bring to the overall legitimacy of the state in aspirations for land reform.

\subsection{Incentives for administrative co-management}

The third principle upon which reforms to administrative co-management in Vietnam could be based is the recognition and development of incentives for state and non-state actors to engage with such reforms. The results drawn from all four chapters of this thesis indicate the need to identify and/or realign incentives for developing and maintaining collaborative forms of SUF management. It is also notable that incentivization has not been covered as a theme in the literature on adaptive co-management. As outlined throughout 
this thesis considerable attention has been given to processual elements relating to enhanced collaboration in the wider co-management literature (see for recent examples Cinner, Daw et al., 2012; Plummer and Baird, 2013; Trimble and Berkes, 2015). However, I argue that understanding the incentive structure, which is more akin to institutional economic approaches (commonly associated with but not limited to payments for ecosystem services like approaches, see Tomich, Thomas et al., 2004; Hoang, Do et al., 2013; Pham, Loft et al., 2015), can also be considered a third principle of reforming administrative co-management in centralized economies like Vietnam. As indicated in Figure 6.1, incentivization can complement both pluralism and accountability, given that it offers a means of encouraging wider engagement with non-state actors beyond legislated rules, and can make more clear the benefits that are available to those engaging in SUF management.

Incentives are framed in Vietnamese policy and legislation as 'benefit sharing', which refers in its broadest sense to the distribution of revenues from activities related to the use of natural resources. No specific reference is made to benefit sharing from SUFs, but as indicated in chapters 3, 4 and 5, a number of benefits are (or could be) derived from economic activities as diverse as non-timber forest products, tourism and (restricted) timber harvesting (see also Sikor and Phuc, 2011; Marschke, Armitage et al., 2012). Overall, however, there is no systematic set of rules or administrative structures that can be drawn on to create clear and transparent benefits sharing mechanisms around SUFs. It is here, I argue, that reforms to the administrative mode of co-management in Vietnam can make a strong impact. In particular, the effective allocation of benefits in SUFs could be enhanced through deliberation amongst a wider group of actors, including economic actors, who - as shown in chapter 4 - are often marginalised from SUF (Co-)management. It can also be enhanced by recognising that it is not only so called 'resource users' (i.e. local people) that can benefit from such benefit sharing models, but also decentralised levels of the state. As argued by Larson and Soto (2008), under the current forestry regime local authorities “... have little motivation to take forest-related initiatives, especially when they have little real authority over, and receive few benefits from, forest resources, when they do, these initiatives tend to emphasize obtaining economic benefits" (Larson and Soto, 2008, p. 220). If a more active mode of co-management is required, then not only legal authority, but also financial benefits need to be considered. However, returning to Figure 6.1, it would appear imperative that systems for accountability be developed in parallel to ensure ongoing trust and intervention of the state at these decentralised levels.

In practical terms benefit sharing mechanisms could take many forms. Experience that already exists in Vietnam include auction systems for access rights as well as taxes and fees generated from tourism (e.g. Lloyd, 2004; Huong and Berkes, 2011; McElwee 2012). Other 
benefit sharing mechanisms such as Payments for Ecosystem Services have also been trialled in Vietnam with varying levels of success (To, Dressler et al., 2012; Pham, Moeliono et al., 2014). Based on the findings of this thesis I would argue that benefit sharing does not have to be complex or offer opportunities for the financialization of SUF resources, especially given that such arrangements tend to remove control over funding from the resources and actors enacting management (see Dressler, Mahanty et al., 2015). Fees, taxes and access leases can all be more localized means of creating incentive mechanisms that can support management in line with co-management arrangements. Such mechanisms can thereby help to overcome deficiencies of administrative co-management and create financial motivations for SUF management among state organizations in addition to nonstate actors including resource users.

Innovations in the delivery of incentives are clearly needed to provide some counterbalance to the growing demand for natural resources in and around SUFs in Vietnam, which is central to driving over-exploitation and biodiversity decline (Brook, Dudley et al., 2014; Nuwer and Bell, 2014; To 2015). This does not amount to a neo-liberalisation of the Vietnamese state, or a turn to the financialisation of environmental governance that disregard the particularities of specific places and peoples (Roth and Dressler, 2012). Instead incentives can be brought into local arrangements led by SUF management boards that can support local management activities. If these incentives can be developed in such a way that they stimulate greater active participation (therefore contributing to the goal of pluralism) and are supported by institutions that ensure accountability of both state and non-state actors at all levels of governance, then administrative co-management can be made more adaptive to local needs and potentially more effective in achieving state-led SUF goals.

\section{Co-management in 'mono-organizational' states}

According to Plummer and FitzGibbon (2004a) the distribution of rights and responsibilities pertaining to a particular resource among governments and local users is central to co-management. However, the emergent language of 'adaptiveness' in the natural resource management academic literature has been highly influential on the expansion of co-management beyond a binary relationship between the state and resource users. Comanagement now entails a far wider set of cross-scale relationships between state and nonstate actors at different levels and scales. It is fundamentally focused on arrangements that enable the continuous interaction between these actors, allowing them to adjust their positions, roles, and activities in processes of problem-solving around the stewardship of natural resource (Carlsson and Berkes, 2005; Armitage et al., 2008). It is this radical decentralisation that challenged the extent to which adaptive forms of co-management can 
be relevant for mono-organisational states like Vietnam. As Pomeroy (1995) pointed out more than 20 years ago, "the actual form of co-management will depend upon the form of government and the political will for decentralization" (Pomeroy, 1995, p. 150). It is exactly this problematic that this thesis has addressed: is adaptive co-management possible in a system of SUFs that represent the central state in Vietnam? In this final section I want to broaden this discussion beyond Vietnam, to mono-organisational states in general.

Administrative co-management is unlikely to be unique to Vietnam. In many countries of Southeast Asia degrees of central control around the management of natural resources, and especially those managed through national park systems, are observed. Indeed in countries like Myanmar, Thailand, Laos and China, national parks have a very similar history to Vietnam in terms of central control leading to local struggles and conflicts (see for example Nepal and Weber, 1995; Pomeroy, Parks et al., 2007; Fox, Fujita et al., 2009; Hanson, Brooks et al., 2009; Peluso and Lund, 2011). While in this short list only China, Myanmar and Laos might be considered 'mono-organizational', the centrality of natural resource and conservation planning is more common to all of these countries - largely (and long understood) as part of wider programs of state building and state control in peripheral regions (Vandergeest and Peluso, 1995; West, Igoe et al., 2006). Transitions towards more participative modes of national park management and conservation have long histories across all of these countries, and the degree to which adaptive co-management is currently in place remains limited by similar findings that emerge in this thesis - suspicion of NGOs, the fear of international notions of democracy eroding sovereign control over resources, and ongoing struggles of marginalized local communities around conservation parks (Roth, 2004; West, Igoe et al., 2006). While single party states like Vietnam, China and Laos face an added layer of political ideology around decentralization and devolution, there remain wider challenges across regions like Southeast Asia in shifting from 'administrative' (in degrees of variation that might be visible from what is defined in this thesis) to adaptive modes of co-management.

It is also likely that in countries with less political space for civil society new arrangements are required to provide NGOs the possibility to act as bridging organizations. This raises the possibility of a staged approach, in which a state agency operating at on-site level at a nexus of state and local people to coordinate all activities relating to resource management can fill an interim role, perhaps with the intention of moving towards the integration of NGOs in a bridging role. Such an agency would not set a precedent in co-management. As outlined by many scholars such as Berkes (2009), Olsson et al. (2007) and Folke et al. (2005), such agencies already exist and coordinate "the interaction of ... different kinds of knowledge (science and local) to co-produce new knowledge, and ... other tasks that enable co-operation: accessing resources, bringing together different actors, building trust, 
common visions and goals, resolving conflicts, and networking" (Folke, Hahn et al., 2005; Olsson, Folke et al., 2007; Berkes, 2009). Bringing centralized states into co-management through such an agency cannot only create adaptive responses from the government in dealing with natural resource management and conservation. It can also inspire changes in perceptions towards the position of state agencies in resource management in the context of centralized states. Nonetheless, returning to the results of this thesis, the success of such an arrangement requires setting clear lines of accountability and incentives for plural and active participation of state and non-state actors alike. A first step towards such changes would require a clear and accountable legal environment at the central level.

Another key reform for moving from administrative to more adaptive forms of comanagement is a change in the attitude and role of resource users. The tendency for centralized states to limit access to resources has in many cases exacerbated problems such as illegal logging. Evidence beyond Vietnam indeed shows that when local people are sidelined and governmental agencies do not have the capacity to police such activities, progress towards effective conservation is severely hampered (Zingerli, 2005; Hayes, 2006; Boissiere, Sheil et al., 2009). A more adaptive regime therefore requires local people to become more active in resource conservation, which in turn emphasizes the need for political support within the state to create partnerships rather than subjects of protected area management. As Ratner et al. (2012) points out, a first step towards such a changed relationship would be a more just distribution of the benefits (and costs) of resource use across scales, which requires addressing not only the allocation of access and use rights but also the mechanisms by which the full range of stakeholders can interact equitably.

Finally, and perhaps above all, any shift from administrative to adaptive co-management requires political will. As Pahl-Wostl (2009) asserted that "there would be no innovation or evolution to higher adaptive capacity if individuals or organizations never revisited basic values or beliefs. A lack of critical self-reflection is a severe constraint for societal learning and transitions to more sustainable resource governance approaches" (Pahl-Wostl, 2009, p. 359). As this thesis shows, states are among the actors who need to exercise social-learning most to boost the entire arrangement move forward to adaptive co-management arrangement. To be more adaptive states have to become more reflexive of what is less or more likely to lead to outcomes that meet both the managerial and political project that comanagement represents. On this basis, shared experiences between mono-organizational states could be a first next step for research and policy alike. 


\section{Recommendations}

To close this thesis, I would like to make an urge for innovation in SUF administrative comanagement arrangements based on the findings of this research by providing recommendations for policy and further research for a better, co-managed, Vietnamese nature conservation.

From the findings, I conclude that SUF co-management is practised and adaptive comanagement is possible in the context of a centralised state such as Vietnam. Boosting SUF administrative co-management - a Vietnamese "style" - towards a more internationally adaptive co-management is a promising process in order to gain effectiveness in SUF nature conservation today. And in this transition process, pluralism, accountability and incentivisation are the three intertwined key principles of the arrangement which should be addressed and placed central by governmental efforts. To do this, firstly the Vietnamese government needs a revision and coordination of the legal and policy framework in which it allows for a certain extension of horizontal networks, especially with local/indigenous resource users and ENGOs. Secondly, accountability of the arrangement needs a careful attention to be reformed in order to ensure greater degrees of trans-active decision making by non-state actors. Some degree of devolution away from the central and provincial government is essential for yielding a high level of trans-active decision-making. And finally, incentives should be developed to stimulate greater active participation in order to gain the goal of pluralism and become more adaptive to local needs and desires. Initial attention could be given to politically less sensitive issues such as the integration of indigenous and scientific knowledge and livelihood development. Overtime, institutional changes that enable devolution of co-management beyond the state should become a main focus. However, after all, any shift from SUF administrative to adaptive co-management requires political will. Fundamentally, Vietnamese state actors need to exercise sociallearning to serve the co-management process, to boost the entire arrangement move forward and to enhance its capacity of adaptiveness. And on this basis, sharing experience among mono-organisational states in the domain of nature conservation could be a first next step.

Finally, based on the findings of this thesis I recommend to further investigate the ability of vertical networks in mono-organizational states to adapt to local and constantly changing conditions. As found in this thesis, moving beyond administrative forms of co-management may require a mix of flexible and adaptable horizontal relations. However, there may be different degrees to which such flexibility can exist within the rigid structure of vertical state control. This raises questions about the relative flexibility and degree of adaptiveness that these states can hope to exhibit. Comparative research on administrative co-management in different 'mono-organisational' states might provide us better insights regarding this issue. 


\section{REFERENCES}

Adger, W.N. (1999). "Evolution of economy and environment: an application to land use in lowland Vietnam.” Ecological Economics 31(3): 365-379.

Adger, W.N., K. Brown and E.L. Tompkins (2005). "The political economy of cross-scale networks in resource co-management." Ecology and Society 10(2).

Affolderbach, J., R.A. Clapp and R. Hayter (2012). "Environmental bargaining and boundary organizations: Remapping British Columbia's Great Bear Rainforest." Annals of the Association of American Geographers 102(6): 1391-1408.

Armitage, D.R., R. Plummer, F. Berkes, R.I. Arthur, A.T. Charles, I.J. Davidson-Hunt, A.P. Diduck, N.C. Doubleday, D.S. Johnson, M. Marschke, P. McConney, E.W. Pinkerton and E.K. Wollenberg (2009). "Adaptive co-management for social-ecological complexity." Frontiers in Ecology and the Environment 7(2): 95-102.

Armitage, D., F. Berkes, A. Dale, E. Kocho-Schellenberg and E. Patton (2011). "Comanagement and the co-production of knowledge: Learning to adapt in Canada's Arctic." Global Environmental Change 21: 995-1004.

Armitage, D., M. Marschke and R. Plummer (2008). "Adaptive co-management and the paradox of learning." Global Environmental Change 18: 86-98.

Armitage, D., F. Berkes, N. Doubleday (2010). Adaptive Co-Management: Collaboration, Learning, and Multi-Level Governance; UBC Press: Vancouver, BC, Canada, 2010.

Arthur, R.I. (2005). Developing, implementing and evaluating policies to support fisheries co-management, MRAG: $12 \mathrm{pp}$.

Baird, J., R. Plummer and O. Bodin (2016). "Collaborative governance for climate change adaptation in Canada: experimenting with adaptive co-management." Regional Environmental Change 16: 747-758.

Barney, K. (2009). "Laos and the making of a 'relational' resource frontier." The Geographical Journal 175(2): 146-159.

Baulch, B. (2010). Ethnic minority poverty in Vietnam. Chronic Poverty Research Centre Working Paper: 169. 
Baulch, B., D. Haughton, J. Haughton and T.T.K. Chuyen (2002). Ethnic minority development in Vietnam: A socioeconomic perspective. World Bank Policy Reseatch Working Paper: 2836.

Bene, C., E. Belal, M.O. Baba, S. Ovie, A. Raji, I. Malasha, F. Njaya, M.N. Andi, A. Russell and A. Neiland (2009). "Power struggle, dispute and alliance over local resources: Analyzing "Democratic" decentralization of natural resources through the lenses of Africa inland fisheries.” World Development 37(12): 1935-1950.

Bennett, N.J. and P. Dearden (2014). "Why local people do not support conservation: Community perceptions of marine protected area livelihood impacts, governance and management in Thailand." Marine Policy 44: 107-116.

Berkes, F. (2009). "Evolution of co-management: Role of knowledge generation, bridging organizations and social learning." Journal of Environmental Management 90: 16921702.

Berkes, F. (2010). "Devolution of environment and resources governance: trends and future.” Environmental Conservation 37(4): 489-500.

Berkes, F., P. George and R. Preston (1991). Co-management: The Evolution of the Theory and Practice of Joint Administration of Living Resources. Common Property Conference, the Second Biennial Conference of the International Association for the Study of Common Property. Winnipeg, Manitoba.

Birdlife International (2016). Vietnam IBA status. [online] http://www.birdlife.org/datazone/country/vietnam/ibas

Boissìere, M., D. Sheil, I. Basuki, M. Wan and H. Le (2009). "Can engaging local people’s interests reduce forest degradation in Central Vietnam?" Biodiversity and Conservation 18(10): 2743-2757.

Borrini-Feyerabend, G., M.T. Farvar, J.C. Nguinguiri and V.A. Ndangang (2007). Comanagement of Natural Resources: Organising, Negotiating and Learning-by-Doing. Kasparek Verlag, Heidelberg (Germany), GTZ and IUCN.

Borrini-Feyerabend, G., M. Pimbert, M.T. Farvar, A. Kothari and Y. Renard, Eds. (2004). Sharing power. Learning by doing in co-management of natural resources throughout the world, IIED, IUCN, CEESP, CMWG. 
Bowers, T., I. Eastin, I. Ganguly, J. Cao and M. Seol (2012). "Forest certification in Asia: The changing marketplace for value-added wood product manufacturers in China and Vietnam." The Forestry Chronicle 88(5): 578-584.

Bown, N.K., T.S. Gray and S.M. Stead (2013). "Co-management and adaptive comanagement: Two modes of governance in a Honduran marine protected area." Marine Policy 39: 128-134.

Brook, S.M., N. Dudley, S.P. Mahood, G. Polet, A.C. Williams, J.W. Duckworth, T.V. Ngoc and B. Long (2014). "Lessons learned from the loss of a flagship: The extinction of the Javan rhinoceros Rhinoceros sondaicus annamiticus from Vietnam." Biological Conservation 174: 21-29.

Brown, L.D. (1991). "Bridging organisations and sustainable development." Human Relations 44: 807-831.

Bui Hai Thiem (2015). “Úng xử với môi trường: Những vận động mới cho công lý và quyền môi trường [Environmental behavior: The new advocacy for justice and environmental rights]." Policy News - PanNature 17-Quater 1/2015: 3-5.

Butler, J.R.A., J.C. Young, I.A.G. McMyn, B. Leyshon, I.M. Graham, I. Walker, J.M. Baxter, J. Dodd and C. Warburton (2015). "Evaluating adaptive co-management as conservation conflict resolution: Learning from seals and salmon." Journal of Environmental Management 160: 212-225.

Campbell, L.M. and A. Vainio-Mattila (2003). "Participatory development and communitybased conservation: Opportunities missed for lessons learned." Human Ecology 31(3): 417-437.

Carlsson, L. and F. Berkes (2005). "Co-management: Concepts and Methodological Implications.” Journal of Environmental Management 75: 65-76.

Cash, D.W., W.N. Adger, F. Berkes, P. Garden, L. Lebel, P. Olsson, and O. Young (2006). Scale and cross-scale dynamics: governance and information in a multilevel world. Ecology and Society, 11(2), 8.

Chen, H., G. Shivakoti, T. Zhu and D. Maddox (2012). "Livelihood Sustainability and Community Based Co-management of Forest Resources in China: Changes and Improvement.” Environmental Management 49: 219-228.

Cinner, J., T. Daw, T. McClanahan, N. Muthiga, C. Abunge, S. Hamed, B. Mwaka, A. Rabearisoa, A. Wamukota and E.Fisher (2012). Transitions toward co-management: 
The process of marine resource management devolution in three east African countries. Glob. Environ. Chang. 22(3): 651-658.

Clement, F. (2010). "Analysing decentralised natural resource governance: proposition for a "politicised" institutional analysis and development framework." Policy Sci 43: 129156.

Clement, F. and J.M. Amezaga (2008). "Linking reforestation policies with land use change in northern Vietnam: Why local factors matter." Geoforum 39: 265-277.

Clement, F. and J.M. Amezaga (2009). "Afforestation and forestry land allocation in northern Vietnam: Analysing the gap between policy intentions and outcomes." Land Use Policy 26(2): 458-470.

Clement, F. and J.M. Amezaga (2013). "Conceptualising context in instituional reforms of land and natural resource management: the case of Vietnam." International Journal of the Commons 7(1): 140-163.

Coe, C.A. (2012). "Local power structures and their effect on forest land allocation in the buffer zone of Tam Dao National Park, Vietnam." The Journal of Environment \& Development 22(1): 74-103.

Coe, C.A. (2015). 'Civilized city': how embedded civil society networks frame the debate on urban green space in Hanoi, Vietnam. Asian Journal of Communication. DOI: 10.1080/01292986.2015.1023321

Cooke, B. and U. Kothari (2001). Participation: The new tyranny? Chicago, Zed Books.

Corbett, J. (2008). Paper Parks and Paper Parnerships: Lessons for protected areas and biodiversity corridors in the Greater Mekong Subregion, IUCN.

Crona, B. and J. Parker (2012). "Learning in support of governance: Theories, methods, and a framework to assess how bridging organizations contribute to adaptive resource governance.” Ecology and Society 17(1): 32.

Cronkleton, P., J.M. Pulhin and S. Saigal (2012). "Co-management in Community Forestry: How the Partial Devolution of Management Rights Creates Challenges for Forest Communities." Conservation and Society 10(2): 91-102.

Crowe, P.R., K. Foley and M.J. Collier (2016). "Operationalizing urban resilience through a framework for adaptive co-management and design: Five experiments in urban planning practice and policy.” Environmental Science \& Policy 62: 112-119. 
Cuong, T.N., N.X. Dung, T.H. Trang, P.B. Minh and P.Q. Le (2009). Some Contents of Vietnamese Biodiversity Management. Hanoi, Department of Biodiversity Conservation.

Davidson, S.L. and R.C. de Loë (2016). "The Changing Role of ENGOs in Water Governance: Institutional Entrepreneurs?” Environmental Management 57: 62-78.

Davidson-Hunt, I.J. and R.M. O'Flaherty (2007). "Researchers, Indigenous Peoples, and Place-based Learning Communities.” Society \& Natural Resources 20: 291-305.

Development Partnerships (2010). Report on Vietnam Development 2010: Natural Resource Management. Hanoi, Vienam, Lebros.

Do Trong Hoan (2014). “Thách thức triển khai các sáng kiến mới trong ngành lâm nghiệp.” Policy News - PanNature 15(Quarter III/2014): 14-16.

Doan Diem (2014). “Sắp xếp, đổi mới nông lâm trường: Đôi điều cần làm.” Policy News PanNature 15(Quy III/2014): 11-13.

Dore, J. (2014). “An Agenda for Deliberative Water Governance Arenas in the Mekong." Water Policy 16: 194-214.

Dressler, W.H., P.X. To and S. Mahanty (2013). "How Biodiversity Conservation Policy Accelerates Agrarian Differentiation: The Account of an Upland Village in Vietnam." Conservation and Society 11(2): 130-143.

Dressler, W.H., S. Mahanty, J. Clendenning and P.X. To (2015). "Rearticulating governance through carbon in the Lao PDR?” Environment and Planning C: Government and Policy 33: 1265-1283.

Dudley, N. (2008). Guidelines for Applying Protected Area Management Categories. Gland, Switzerland, IUCN.

Dung, V.V., T.Q. Bao et al. (2002). Project on enhancing the management of Vietnam protected area system: Draft report on suggesting categories of Vietnam protected areas Hanoi, Vietnam Forestry Protection Department.

Duong Hong Thanh (2015). "Giám sát môi trường của các cơ quan dân cử: có giám mà không sát.” Policy News - PanNature 17(Quarter I/2015): 24-26.

Espinosa-Romero, M.J., L.F. Rodriguez, A.H. Weaver, C. Villanueva-Aznar and J. Torre (2014). The changing role of NGOs in Mexican small-scale fisheries: From environmental conservation to multi-scale governance. Marine Policy, 50, 290-299. 
Essen, E. van and H.P. Hansen (2015). "How stakeholder co-management reproduces conservation conflicts: revealing rationality problems in Swedish Woff Conservation." Conservation and Society 13(4): 332-344.

Evans, L., N. Cherrett and D. Pemsl (2011). "Assessing the impact of fisheries comanagement inverventions in developing countries: A meta-analysis." Journal of Environmental Management 92(8): 1938-1949.

Fabres, B. (2011). Think global, act global in the Mekong Delta? Environmental change, civil society, and NGOs. Environmental Change and Agricultural Sustainability in the Mekong Delta. M.A. Stewart and P.A. Coclanis, Advances in Global Change Research. 45: 7-34.

Fabricius, C. and B. Currie (2015). Adaptive Co-Management. In Allen, C.R. and Garmestani, A.S. Adaptive Management of Social-Ecological Systems pp. 147-179. Springer: Dordrecht.

FAO (2016). Global Forest Resources Assessment 2015: How Are the World's Forest Changing? Rome, Food and Agriculture Organisation of the United Nations: 54.

FFI (2013) Where we work. FFI [Online: http://www.fauna-flora.org/explore/vietnam/] (Accessed: 16 June 2013)

Finkbeiner, E.M. and X. Basurto (2015). "Re-defining co-management to facilitate smallscale fisheries reform: An illustration from northwest Mexico." Marine Policy 51: 433-441.

Flyvbjerg, B. (2006). "Five misunderstandings about case-study research." Qualitative inquiry 12(2): 219-245.

Folke, C., S. Carpenter, T. Elmqvist, L. Gunderson, C.S. Holling and B. Walker (2002). "Resilience and sustainable development: building adaptive capacity in a world of transformations." AMBIO: A Journal of the Human Environment 31(5): 437-440.

Folke, C., T. Hahn, P. Olsson and J. Norberg (2005). “Adaptive governance of socialecological systems." Annual Review of Environment and Resources 30: 441-473.

Fox, J., Y. Fujita, D. Ngidang, N. Peluso, L. Potter, N. Sakuntaladewi, J. Sturgeon and D. Thomas (2009). "Policies, Political-Economy, and Swidden in Southeast Asia." Human Ecology 37: 305-322.

Fritzen, S.A. (2006). "Probing Systems Limits: Decentralisation and Local Political Accountability in Vietnam." Asia Pacific Journal of Public Administration 28(1): 1-23. 
Gainsborough, M. (2007). "Globalisation and the state revisited: A view from provincial Vietnam.” Journal of Contemporary Asia 37(1): 1-18.

García-Herrera, J.J. (2009). Handbook of ecotourism in protected areas of Vietnam. Fundación Desarrollo Sostenido (FUNDESO), Madrid.

Government of Vietnam (2001). Decision No. 08/2001/QD-T'Tg dated 11/01/2001 of The Prime Minister on issuing Regulations on the Management of Special-use Forests, Environmental Forests, and Natural Productive Forests. No. 08/2001/QDTTT. Hanoi. No. 08/2001/QD-TTg.

Government of Vietnam (2003). Decision of the Prime Minister to Approve the Management Strategy for a Protected Area System in Vietnam to 2010. No.192/2003/QD-TTg. V. Government. Hanoi. No.192/2003/QD-T'Tg.

Government of Vietnam (2013). Quyết định số 1250/2013/QĐ-TTg về phê duyệt Chiến lược quốc gia về đa dạng sinh học đến năm 2020, tầm nhìn đến năm 2030. Decision 1250/2013/QD-T'Tg.

Government of Vietnam (2014). Decision 1976/QD-TTg on Ratifying the plan on the national system of Special Use Forests upto 2020, visioning to 2030. No. 1976/QDT'Tg. T. V. Government. Hanoi, Vietnam. No. 1976/QD-T'Tg.

Ha, T.T.T. and S.R. Bush (2010). "Transformations of Vietnamese Shrimp Aquaculture Policy: Empirical Evidence from the Mekong Delta." Environment and Planning C: Government and Policy 28(6): 1101-1119.

Hahn, T. (2006). Trust-building, Knowledge Generation and Organizational Innovations: The Role of a Bridging Organization for Adaptive Comanagement of a Wetland Landscape around Kristianstad, Sweden. Human Ecology 34: 573-592.

Hannah, J. (2009). The mutual colonization of state and civil society organizations in Vietnam. In B. Read and R. Pekkanen, Local Organizations and Urban Governance in East and Southeast Asia: Straddling state and society, pp. 84-100. Routledge: London.

Hanson, T., T.M. Brooks, G.A.B.D. Fonseca, M. Hoffmann, J.F. Lamoreux, G. Machlis, C.G. Mittermeier, R.A. Mittermeier and J.D. Pilgrim (2009). "Warfare in Biodiversity Hotspots." Conservation Biology 23(3): 578-587.

Harkes, I.H.T. (2006). Fisheries co-management, the role of local institutions and decentralisation in Southeast Asia: With specific reference to marine sasi in Central Maluku, Indonesia. Doctor, Leiden University. 
Hayes, T.M. (2006). "Parks, People, and Forest Protection: An Institutional Assessment of the Effectiveness of Protected Areas.” World Development 34(12): 2064-2075.

Helene, I.H.T. (2006). Fisheries co-management, the role of local institutions and decentralisation in Southeast Asia - With specific reference to marine sasi in Central Maluku, Indonesia. Doctorate, Leiden University.

Hersoug, B. and S.A. Rånes (1997). "What is good for the fishermen, is good for the nation: co-management in the Norwegian fishing industry in the 1990s." Ocean \& Coastal Management 35(2-3): 157-172.

Ho, P. (2001). "Who Owns China's Land? Policies, Property Rights and Deliberate Institutional Ambiguity." The China Quarterly 166: 394-421.

Ho, T.V.T., S. Woodley, A. Cottrell and P. Valentine (2014). "A multilevel analytical framework for more-effective governance in human-natural systems: A case study of marine protected areas in Vietnam." Ocean \& Coastal Management.

Hoang V.N. (2015). "Quyền môi trường và sự tham gia của người dân trong thực hiện quyền môi trường [Environmental rights and the participation of citizens in the implementation of environmental rights]." Policy News - PanNature 17(Quarter $\mathrm{I} / 2015)$.

Hoang, M.H., T.H. Do, M.T. Pham, M. van Noordwijk and P.A. Minang (2013). "Benefit distribution across scales to reduce emissions from deforestation and forest degradation (REDD+) in Vietnam.” Land Use Policy 31: 48-60.

Hong, P.D.V. and N.V. Cach (2007). Xuan Thuy National Park: Management. Hanoi, VEPA_MCD.

Huong, T.T.T. and F. Berkes (2011). "Diversity of resource use and property rights in Tam Giang Lagoon, Vietnam.” International Journal of the Commons 5(1): 130-149.

ICEM (2003). Lessons learned in Cambodia, Laos PDR, Thailand and Vietnam. Review of Protected Areas and Development in the Lower Mekong River Region Indooroopilly, Queensland, Australia: 104.

ICEM (2003). Vietnam National Report on Protected Areas and Development. Review of Protected Areas and Development in the Lower Mekong River Region. Indooroopilly, Queensland, Australia: 66. 
IIED (2015) Themes. International Institute for Environment and Development [Online: http://www.iied.org/community-based-adaptation-climate-change-conference-fieldsites\#s2] (Accessed: 27 July 2015)

iSEE and VUSTA-CARE-ENABLE Project (2008). Summary report on VNGOs operating in sector of rural development. Hanoi, Vietnam., iSSE; VUSTA-CARE.

IUCN (2006). “Community conserved arears.” Parks 16(1): 11.

IUCN (2010). "Co-management and governance in Vietnam: some reflections." Retrieved 14/11/2015, from http://www.iucn.org/news_homepage/news_by_date/?5020/Co-Management-andGovernance-in-Vietnam-Some-Reflections.

Jentoft, S. (2000). "Legitimacy and disappointment in fisheries management." Marine Policy 24: 141-148.

Jentoft, S. and B.J. McCay (1995). "User participation in fisheries management. Lessons drawn from international experiences.” Marine Policy 19: 227-246.

Jong, W.D., D.S. Do and V.H. Trieu (2006). Forest Rehabilitation in Vietnam: Histories, Realities, and Future. Jakarta, CIFOR.

Kemper, N., L.V. Ha and R. Klump (2013). "Property Rights and Consumption Volatility: Evidence from a Land Reform in Vietnam." World Development 71: 107-130.

Kendrick, A. (2003). Caribou co-management in northern Canada: fostering multiple ways of knowing. Navigating Social-ecological Systems. F. Berkes, J. Colding and C. Folke. Cambridge, Cambridge University Press: 241-267.

KimDung, N., S.R. Bush and A.P.J. Mol (2013). “Administrative co-management: The case of special-use forest conservation in Vietnam." Environmental Management 51(3): 616-630.

KimDung, N., S.R. Bush and A.P.J. Mol (2016a). "The Vietnamese State and Administrative Co-Management of Nature Reserves." Sustainability 8(292).

KimDung, N., S.R. Bush and A.P.J. Mol (2016b). "NGOs as bridging organisations in managing nature protection in Vietnam." Journal of Environment and Development 25(2): 191-218.

Kooiman, J. and M. Bavinck (2005). The governance perspective. F. f. l. I. g. f. fisheries. Vancouver: 11-14. 
Kumar, R. (2005). Research Methodology: A step-by-step guide for beginners, SAGE Publications Inc.

Lai, T.P. (2008). Fisheries co-management in Vietnam: issues and approach. Achieving a Sustainable Future: Managing Aquaculture, Fishing, Trade and Development, Nha Trang, Vietnam, IIFET.

Larsen, P.B. (2008). Linking livelihoods and protected area conservation in Vietnam: Phong Nha Ke Bang World Heritage, local futures? People, Protected Areas and Global Change: Participatory Conservation in Latin America, Africa, Asia and Europe. Galvin M and H.T. Bern: Geographical Bernensia, Perspectives of the Swiss National Centre of Competence in Research (NCCR) North-South, University of Bern. 3: 431 470.

Larson, A.M. and F. Soto (2008). "Decentralization of Natural Resource Governance Regimes.” Annual Review of Environment and Resources 33: 213-239.

Lebel, L., J.M. Anderies, B. Campbell, C. Folke, S. Hatfield-Dodds, T.P. Hughes and J. Wilson (2006). "Governance and the Capacity to Manage Resilience in Regional Social-Ecological Systems.” Ecology and Society 11(1): 19.

Lloyd, K. (2004). "Tourism and transitional geographies: Mismatched expectations of tourism investment in Vietnam.” Asia Pacific Viewpoint 45(2): 197-215.

Lloyd, R. (2010). Co-management in Au Tho B Village - A pilot test for the coastal zone of Soc Trang Province. Management of Natural Resources in the Coastal Zone of Soc Trang Province. Soc Trang Province, Vietnam, GTZ.

Lund, C. (2014). "Of what is this a case?: analytical movements in qualitative social science research.” Human Organization 73(3): 224-234.

Lux, S.J. and J.D. Straussman (2004). "Searching for balance: Vietnamese NGOs operating in a state-led civil society." Public Administration and Development 24: 173-181.

Macfadyen, G., P. Cacaud and B. Kuemlangan (2005). Policy and legislative frameworks for co-management. Paper prepared for the APFIC Regional Workshop on Mainstreaming Fisheries Co-management in Asia Pacific. Siem Reap, Cambodia, 9-12 August 2005. FAO/FishCode Review. No.17. Rome, FAO.: 51p.

MARD (2005). National report to the Fifth session of the United Nations Forum on Forests. Hanoi, Vietnam, MARD. 
Marín, A. and F. Berkes (2010). "Network approach for understanding small-scale fisheries governance: The case of the Chilean coastal co-management system." Marine Policy 34: 851-858.

Marín, A., S. Gelcich, J.C. Castilla and F. Berkes (2012). "Exploring Social Capital in Chile's Coastal Benthic Co-Management System Using a Network Approach.” Ecology and Society 17(1): 13 .

Marschke, M., D. Armitage, L.V. An, T.V. Tuyen and H. Mallee (2012). "Do collective property rights make sense? Insights from central Vietnam.” International Journal of the Commons 6(1): 1-27.

Masuda, M., S. Iwanaga, N. Kaida and K. Yoshino (2016). "Forest conservation and rehabilitation policies in Vietnam: their assessments and local responses." Tropics 24(4): 139-140.

McBeath, J. and J. Rosenberg (2006). Advances in global change research: Comparative environmental politics, Springer.

McCay, B.J. and J. Svein (1996). From the Bottom Up: Participatory Issues in Fisheries Management. Society and Natural Resources 9: 237-250.

MCD (2015). About Us. MCD [Online: http://mcdvietnam.org/who-we-are/ ] (Accessed: 26 July 2015)

McElwee, P. (2004). "You say illegal, I say legal: the relationship between illegal' logging and land tenure, poverty, and forest use rights in Vietnam." Journal of Sustainable Forestry 19(1/2/3): 97-135.

McElwee, P. (2006). "Displacement and relocation redux: Stories from Southeast Asia." Conservation and Society 4(3): 396-403.

McElwee, P. (2009). "Reforesting 'bare hills' in Vietnam: social and environmental consequences of the 5 Million Hectare Reforestation Program." Ambio: A Journal of the Human Environment 38(6): 325-333.

McElwee, P. (2010). "Resource use among rural agricultural households near protected areas in Vietnam: The social cost of conservation and implications for enforcement." Environmental Management 45: 113-131.

McElwee, P. (2016). Forest are gold: Trees, People, and Environmental Rule in Vietnam. United States of America, University of Washington Press. 
McElwee, P.D. (2012). "Payments for environmental services as neoliberal market-based forest conservation in Vietnam: Panacea or problem?” Geoforum 43: 412-426.

McElwee, P., T. Nghiem, H. Le, H. Vu and N. Tran (2014). "Payments for environmental services and contested neoliberalisation in developing countries: A case study from Vietnam." Journal of Rural Studies 36: 423-440.

Meyfroidt, P. and E.F. Lambin (2008a). "The causes of the reforestation in Vietnam." Land Use Policy 25: 182-197.

Meyfroidt, P. and E.F. Lambin (2008b). "Forest transition in Vietnam and its environmental impacts." Global Environmental Change 14: 1319-1336.

Meyfroidt, P. and E.F. Lambin (2009). "Forest transition in Vietnam and displacement of deforestation abroad.” PNAS 106(38): 16139-16144.

Millet, J., N. Tran, N.V. Ngoc, T.T. Thi and D. Prat (2013). "Enrichment planting of native species for biodiversity conservation in a logged tree plantation in Vietnam." New Forests 44(44): 369-383.

Mittermeier, R.A., P. Robles Gil, M. Hoffmann, J.D. Pilgrim, T.M. Brooks, C.G. Mittermeier and G.A.B. Fonseca (2004). Hotspot Revisited: Earth's Biologically Richest and Most Endangered Ecoregions. Mexico City, CEMEX.

MoF (1986). Regulations on three types of forests: production forests, protection forests, and special-use forests. V. M. o. Forestry. Decree 1171-QD.

MONRE (2011a). 2010 Vietnam Environmental Report: Overview of Vietnam Environment. Hanoi, Ministry of Natural Resource and Environment.

MONRE (2011b). National report on biodiversity. Hanoi, Vietnam.

Nambiar, E.S., C.E. Harwood and N.D. Kien (2015). “Acacia plantations in Vietnam: Research and knowledge application to secure a sustainable future." Southern Forests $77(1): 1-10$.

Nepal, S.K. and K.W. Weber (1995). "Managing resources and resolving conflicts: national parks and local people." International Journal of Sustainable Development and World Ecology 2(1): 11-25.

Nghia, H.V. (2011). "Vai trò và hoạt động của các tổ chức xã hội trong việc bảo vệ, giám sát môi trường [Roles and Operations of Civil Society Organizations in 
Environmental Monitoring and Protection].” Nghiên cứu Lập pháp [Legislation Research] 18(203): 18-25.

Nguyen Hai Van (2014). "Nghiên cứu về chồng lấn quyền sử dụng dất rừng đặc dụng [A Study on Overlaps in Right Uses of Special Use Forest Lands].” Policy News PanNature 15(Quarter III/2014): 32.

Nguyen Hai Van and Nguyen Viet Dung (2015). Overlapping rights of Special-Use forest landuse: challenges for master plans and Special-Use forest management in Vietnam. Hanoi, Vietnam, Hong Duc Publication House.

Nguyen Huy Dung and V.V. Dung (2007). Biodiversity Protection in Vietnam - Relations to Sustainable Development and Climate Change. Biodiversity and Climate Change: Relations to Poverty and Sustainable Development, Hanoi, Vietnam.

Nguyen Thanh Huyen (2013). Laws on forest resource management and protection in Vietnam. Hanoi, Vietnam, The National Politics Publisher.

Nguyen Viet Dung (2014). "Ba vấn đề quản lý nhà nước về bảo tồn đa dạng sinh học." Policy News - PanNature 16(Quater IV/2014): 6-8.

Nicol, H.N. (2014). "Nunavut, Sovereignty, and the Future for Arctic Peoples' Involvement in Regional Self-Determination." Northern Review 37.

Noble, B.F. (2000). “Institutional criteria for co-management.” Marine Policy 24: 69-77.

Nørlund, I. (2007). "Civil society in Vietnam: Social organizations and approaches to new concepts.” ASIEN 105: 68-90.

Notzke, C. (1995). "A New Perspective in Aboriginal Natural Resource Management: Comanagement." Geoforum 26(2): 187-209.

Nui Chua national park (2008). A Report on An Evaluation of Natural, Environmental, Economic, and Social Aspects of Villages around Marine Area of Nui Chua National Park.

Nuwer, R. and D. Bell (2014). "Identifying and quantifying the threats to biodiversity in the U Minh peat swamp forests of the Mekong Delta, Vietnam.” Oryx 48(1): 88-94.

Oh, E.J.V. (2010). Property rights, societal structure, and state-society relations: The emergence and prospects of co-management in Vietnam. Revisiting Agrarian Transformations in Southeast Asia: Empirical, Theoretical and Applied Perspectives. Chiang Mai, Thailand: 13. 
Olsson, P., C. Folke, V. Galaz, T. Hahn and L. Schultz (2007). "Enhancing the fit through adaptive co-management: creating and maintaining bridging functions for matching scales in the Kristianstads Vattenrike Biosphere Reserve, Sweden." Ecology and Society 12(1).

Ostrom, E. (2009). “A general framework for analyzing sustainability of Social-Ecological systems." Science 325.

Ostrom, E. and M. Cox (2010). "Moving beyond panaceas: a multi-tier dianostic approach for social-ecological analysis." Environmental Conservation 37(4): 451-463.

Pahl-Wost, C. and M. Hare (2004). "Processes of social learning in integrated resources management.” Journal of Community and Applied Social Psychology 14: 193-206.

Pahl-Wost, C., J. Sendzimir, P. Jeffrey, J. Aerts, G. Berkamp and K. Cross (2007). "Managing Change torward Adaptive Water Management through Social Learning." Ecology and Society 12(2).

Pahl-Wostl, C. (2009). “A conceptual framework for analysing adaptive capacity and multilevel learning process in resource governance regimes." Global Environmental Change 19: 354-365.

Pahl-Wostl, C., M. Craps, A. Dewulf, E. Mostert, D. Tabara and T. Taillieu (2007). "Social Learning and Water Resources Management.” Ecology and Society 12(2).

Pamela, M. (2010). "Resource use among rural agricultural households near protected areas in Vietnam: The social costs of conservation and implications for enforcement “ Environmental management 45(1): 113-131.

PanNature (2011a). Quarterly Policy Review. No.1. Quarter 1/2011, People and Nature Reconciliation

PanNature (2014). Handbook: Skills for enhancing community participation in forest management. Hanoi, Hong Duc Publishing House.

PanNature (2015) About Us. PanNature [Online: http://www.nature.org.vn/en/about/support-us/donors/] (Accessed: 20 July 2015)

PanNature, CORENAM and CRD (2014). A sumary report: The status quo of overlapping rights of landuse in the system of Vietnam Special-Use forests. Hanoi, Vietnam, FORLAND. 
PARC Project (2004). Policy brief: Covering the costs of Viet Nam's protected areas. Hanoi, Vietnam, UNDP, UNOPS, Forest Protection Department, IUCN.

PARC Project (2006). Creating Protected Areas for Resource Conservation Using Landscape Ecology (PARC) Project VIE/95/G31\&031. Policy Brief: Building Vietnam's National Protected Areas System - Policy and Institutional Innovations Required for Progress. Hanoi, Government of Vietnam (FPD)/UNOPS/UNDP/IUCN.

PARC Project (2006). Policy brief: Building Vietnam's National Protected Areas System: Policy and Institutional Innovations Required for Progress. In: Creating Protected Areas for Resource Conservation Using Landscape Ecology (PARC) Project F.P. Department, U. N. D. P. (UNDP) and T.W.C.U. (IUCN). Hanoi.

Parr, J.W.K., P. Insua-Cao, H. V. Lam, H.V. Tue, N.B. Ha, N.V. Lam, N.N. Quang, N.T. Cuong and B. Crudge (2013). "Multi-level co-management in government-designated protected areas-opportunities to learn from models in mainland Southeast Asia." Parks 19(2): 59-74.

Peluso, N. (1993). "Coercing conservation? The politics of state resource control." Global Environmental Change 3(2): 199-217.

Peluso, N.L. and C. Lund (2011). "New frontiers of land control: Introduction." The Journal of Peasant Studies 38(4): 667-681.

Persha, L. and K. Andersson (2014). "Elite capture risk and mitigation in decentralized forest governance regimes." Global Environmental Change 24: 265-276.

Pham, T.T., Campbell, B.M., Garnett, S., Aslin, H. and Hoang, M. H. (2010). Importance and impacts of intermediary boundary organizations in facilitating payment for environmental services in Vietnam. Environmental Conservation, 37(01), 64-72.

Pham, T.T., L. Loft, K. Bennett, V.T. Phuong, L.N. Dung and J. Brunner (2015). "Monitoring and evaluation of Payment for Forest Environmental Services in Vietnam: From myth to reality." Ecosystem Services 16: 220-229.

Pham, T.T., M.D. Gregorio, R. Carmenta, M. Brockhaus and D.N. Le (2014). "The REDD+ policy arena in Vietnam: participation of policy actors." Ecology and Society 19(2).

Pham, T.T., M. Moeliono, M. Brockhaus, D.N. Le, G.Y. Wong and T.M. Le (2014). "Local Preferences and Strategies for Effective, Efficient, and Equitable Distribution of PES Revenues in Vietnam: Lessons for REED+.” Human Ecology 42: 885-899. 
Phuc, N.Q., A.C.M. van Westen and A. Zoomers (2014). "Agricultural land for urban development: The process of land conversion in Central Vietnam." Habitat International 41: 1-7.

Phuc, T.X. and T. Sikor (2008). The Politics of illegal Logging in Vietnam. Working Paper 05 DEV Working Paper Series. U. o. E. A. The School of Development Studies, UK.

Pilgrim, J.D. and N.D. Tu (2007). Background paper on threatened and alien species in Vietnam and recommendations for the content of the Biodiversity Law. Report to the Department of Environment, MONRE. Hanoi, Birdlife International Programme.

Pinkerton, E.W. (1994). "Local Fisheries Co-management: A Review of International Experiences and Their Implications for Salmon Management in British Columbia." Canadian Journal of Fisheries and Aquatic Sciences 51(10): 2363-2378.

Plummer, R. (2009). "The adaptive co-management process: an initial synthesis of representative models and influential variables." Ecology and Society 14(2).

Plummer, R. (2013). "Can adaptive comanagement help to address the challenges of climate change adaptation?” Ecology and Society 18(4).

Plummer, R. and D. Armitage (2007). "A resilience-based framework for evaluating adaptive co-management: Linking ecology, economics and society in a complex world." Ecological Economics 61: 62-74.

Plummer, R. and J. Baird (2013). "Adaptive Co-Management for Climate Change Adaptation: Considerations for the Barents Region.” Sustainability 5(2): 629-642.

Plummer, R. and D.A. Fennell (2009). "Managing protected areas for sustainable tourism: prospects for adaptive co-management." Journal of Sustainable Tourism 17(2): 149168.

Plummer, R. and J. FitzGibbon (2004a). "Co-management of Natural Resources: A Proposed Framework.” Environmental Management 33(6): 876-885.

Plummer, R. and J. FitzGibbon (2004b). "Some observations on the terminology in cooperative environmental management." Journal of Environmental Management 70: 63-72.

Plummer, R. and J. FitzGibbon (2006). "People matter: The importance of social capital in the co-management of natural resources." Natural Resources Forum 30: 51-62. 
Pomeroy, R.S. (1995). "Community-based and co-management institutions for sustainable coastal fisheries management in Southeast Asia." Ocean \& Coastal Management 27(3): 143-162.

Pomeroy, R.S. and F. Berkes (1997). "Two to tango: the role of government in fisheries comanagement.” Marine Policy 21(5): 465-480.

Pomeroy, R.S. and R. Rivera-Guieb (2006). Fishery Co-management: Practical Handbook, CABI Publishing Wallingford, UK and International Development Research Centre, Ottawa, Canada.

Pomeroy, R.S., P. McConney and R. Mahon (2004). "Comparative analysis of coastal resource co-management in the Caribbean.” Ocean \& Coastal Management 47: 429447.

Pomeroy, R., J. Parks, R. Pollnac, T. Campson, E. Genio, C. Marlessy, E. Holle, M. Pido, A. Nissapa, S. Boromthanarat and N.T. Hue (2007). "Fish war: Conflict and collaboration in fisheries management in Southeast Asia." Marine Policy 31: 645-656.

Pomeroy, R., K.A.T. Nguyen and H.X. Thong (2009). "Small-scale marine fisheries policy in Vietnam." Marine Policy 33: 419-428.

PPC, N.D. (2006). A piloting project on sustainable use of clams resources in a wetland of river estuary of Xuan Thuy National Park. Nam Dinh Province, Vietnam, Nam Dinh PPC.

Rathwell, K.J. and G.D. Peterson (2012). "Connecting Social Networks with Ecosystem Services for Watershed Governance: a Social-Ecological Network Perspective Highlights the Critical Role of Bridging Organisations." Ecology and Society 17(2).

Rathwell, K., D. Armitage, and F. Berkes (2015). Bridging knowledge systems to enhance governance of environmental commons: A typology of settings. International Journal of the Commons, 9(2). DOI: 10.18352/ijc.584

Ratner, B.D., E.J.V. Oh and R.S. Pomeroy (2012). "Navigating change: Second-generation challenges of small-scale fisheries co-management in the Philippines and Vietnam." Journal of Environmental Management 107: 131-139.

Redpath, S.M., J. Young, A. Evely, W.M. Adams, W.J. Sutherland, A. Whitehouse, A. Amar, R.A. Lambert, J.D.C. Linnell, A. Watt and R.J. Gutierrez (2013). "Understanding and managing conservation conflicts." Trends in Ecology \& Evolution 28(2): 100-109. 
Ribot, J.C., A. Agrawal and A.M. Larson (2006). "Recentralizing while decentralizing: how national governments reappropriate forest resources." World Development 34(11): 1864-1886.

Rigby, T.H. (1982). Introduction: Political legitimacy, Weber and communist monoorganisational systems. Political legitimation in communist states. Palgrave Macmillan, UK: 1-26.

Ritchie, J., J. Lewis, C.M. Nicholls and R. Ormston (2013). Qualitative research practice: A guide for social science students and researchers, SAGE.

Rodon, T. (1998). “Co-management and self-determination in Nunavut.” Polar Geography 22(2): 119-135.

Roth, R. (2004). "On the colonial margins and in the global hotspot: Park-people conflicts in highland Thailand." Asia Pacific Viewpoint 45(1): 13-32.

Roth, R.J. and W. Dressler (2012). "Market-oriented conservation governance: The particularities of place." Geoforum 2012(43): 363-366.

Rugendyke, B. and N.T. Son (2005). "Conservation costs: Nature-based tourism as development at Cuc Phuong National Park, Vietnam.” Asia Pacific Viewpoint 46(2): 185-200.

Sam, D.D. and L.Q. Trung (2001). "Forest Policy Trends in Vietnam." Policy Trend Report: 69-73.

Sandbrook, C., N.P. Trong, K. Lee and M. Grieg-Gran. (2010). "Co-management of Forests and Wildlife in the Bi Doup-Nui Ba (BD-NB) Nature Reserve, Vietnam “ Retrieved 28/12/2011, from http://www.iied.org/sustainablemarkets/keyissues/environmental-economics/co-managementforests-and-wildlifevietnam

Sandström, A. and C. Rova (2010). "Adaptive co-management networks: a comparative analysis of two fishery conservation areas in Sweden." Ecology and Society 15(3).

Schlager, E. and E. Ostrom (1992). "Property-Rights Regimes and Natural Resources: A Conceptual Analysis.” Land Economics 68(3): 249-262.

Schultz, L., A. Duit and C. Folke (2011). "Participation, Adaptive Co-management, and Management Performance in the World Network of Biosphere Reserves." World Development 39(4): 662-671. 
Seawright, J. and J. Gerring (2008). "Case Selection Techniques in Case Study Research." Political Research Quaterly 61(2): 294-308.

Sen, S. and J.R. Nielsen (1996). "Fisheries co-management: a comparative analysis." Marine Policy 20: 405-418.

Shackleton, S., B. Campbell, E. Wollenberg and D. Edmunds (2002). "Devolution and community-based natural resource management: Creating space for local people to participate and benefit?” Natural Resource Perspectives 76.

Shah, K.U. (2011), Organizational Legitimacy and the Strategic Bridging Ability of Green Alliances, Business Strategy and the Environment 20: 498-511.

Shenton, A.K. (2004). "Strategies for ensuring trustworthiness in qualitative research projects." Education for information 22(2): 63-75.

Sikor, T. (2001). "The allocation of forestry land in Vietnam: did it cause the expansion of forests in the northwest?" Forest Policy and Economics 2: 1-11.

Sikor, T. and T.N. Thanh (2007). "Exclusive versus inclusive devolution in forest management: Insights from forest land allocation in Vietnam's Central Highlands." Land use policy 24: 644-653.

Sikor, T. and T.Q. Nguyen (2007). "Why may forest devolution not benefit the rural poor? Forest entitlements in Vietnam's Central Highlands." World Development 35(11): 2010-2025.

Sikor, T. and T.X. Phuc (2011). "Illegal logging in Vietnam: Lam Tac (Forest Hijackers) in practice and talk.” Society \& Natural Resources 24(7): 688-701.

Sowerwine, J.C. (2004). "Territorialisation and the politics of highland landscapes in Vietnam: negotiating property relations in policy, meaning and practice." Conservation and Society 2(1): 97-136.

Sunderlin, W.D. (2006). "Poverty alleviation through community forestry in Cambodia, Laos, and Vietnam: An assessment of the potential." Forestry Policy and Economics 8(4): 386-396.

Sunderlin, W.D. and Huynh Thu Ba (2005). Poverty Alleviation and Forests in Vietnam. Indonesia, CIFOR.

Swan, S. (2010). Co-management: Concepts and Practices in Vietnam. Proceedings of The National Workshop on Co-management Concept and Practice in Vietnam, Soc Trang, Vietnam, GIZ. 
Tan, N.Q., N.V. Chinh and V.T. Hanh (2008). Đánh giá các rào cản ảnh hưởng tới quản lý rừng bền vững và công bằng: Nghiên cứu điểm ở Việt Nam (An evaluation of barriers impacting on sustainable forest management and equity: A case study of Vietnam). Hanoi, Vietnam, IUCN: iii+35 pp.

Tan, N.Q., N.V. Chinh and V.T. Hanh (2008). Evaluating policy barriers impacting on sustainable forest management and equity: A case study in Vietnam. Hanoi, Vietnam, IUCN: iii+35 pp.

Thanh, T.N. and T. Sikor (2006). "From legal acts to actual powers: Devolution and property rights in the Central Highlands of Vietnam." Forest Policy and Economics 8: 397-408.

Thayer, C.A. (1995). "Mono-organizational socialism and the state." Vietnam's rural transformation: 39-64.

Thayer, C.A. (2009). "Vietnam and the Challenge of Political Civil Society." Contemporary Southeast Asia: A Journal of International and Strategic Affairs 31(1): 1-27.

Ting, Z., G.P. Shivakoti, C. Haiyun and D. Maddox (2012). "A survey-based evaluation of community-based co-management of forest resources: a case study of Baishuijiang National Natural Reserve in China.” Environ Dev Sustain 14: 197-220.

To, P.X. (2009). "Why did the forest conservation policy fail in the Vietnamese uplands? Forest conflicts in Ba Vi National Park in Northern Region." International Journal of Environmental Studies 66(1): 59-68.

To, P.X. (2014). “Quản lý lâm nghiệp nhìn từ quy hoạch và thị trường.” Policy News PanNature 15(Quy III/2014): 8-10.

To, P.X. (2015). “ State Territorialization and Illegal Logging: The Dynamic Relationships between Practices and Images of the State in Vietnam." Critical Asian Studies 47(2): 229-252.

To, P.X., S. Mahanty and W.H. Dressler (2015). “'A new landlord’ (địa chủ mới)? Community, land conflict and State Forest Companies (SFCs) in Vietnam." Forest Policy and Economics 58: 21-28.

To, P.X., W.H. Dressler and S. Mahanty (2012). "The prospects for payment for ecosystem services (PES) in Vietnam: A look at three payment schemes." Human Ecology 40: 237-249. 
To, P.X., W.H. Dressler, S. Mahanty, T.T. Pham and C. Zingerli (2012). “The Prospects for Payment for Ecosystem Services (PES) in Vietnam: A Look at Three Payment Schemes." Human Ecology 40: 237-249.

Tomich, T.P., D.E. Thomas and M. van Noordwijk (2004). "Environmental services and land use change in Southeast Asia: from recognition to regulation or reward?" Agriculture, Ecosystems and Environment 104: 229-244.

Trimble, M. and F. Berkes (2015). "Towards adaptive co-management of small-scale fisheries in Uruguay and Brazil: lessons from using Ostrom's design principles." Maritime Studies 14(14).

Tu, T.N., P. Burgers and A. Zoomers (2014). Co-management of Forests and Forest Land Under Decentralization Process in Central Vietnam. In Science, Policy and Politics of Modern Agricultural System (pp. 333-356). Springer Netherlands.

Ty, P.H., A.C.M. van Westen and A. Zoomers (2013). "Compensation and Resettlement Policies after Compulsory Land Acquisition for Hydropower Development in Vietnam: Policy and Practice." Land 2: 678-704.

UNDP \& Government of Vietnam \& GEF (2010). UNDP Project Document: Removing Barriers Hindering Protected Area Management Effectiveness in Vietnam. Hanoi, Vietnam.

USAID (2013). Vietnam tropical forest and biodiversity assessment, Sun Mountain International and The Cadmus Group, Inc.

USAID's Coral Triangle Support Partnership (2013). Guidelines for Establishing Comanagement of Natural Resources in Timor-Leste. CTI-CFF. Jakarta, Indonesia.

Vandergeest, P. (2003). "Land to some tillers: development-induced displacement in Laos." International Social Science Journal 55(175): 47-56.

Vandergeest, P. and N.L. Peluso (1995). "Territorialization and state power in Thailand." Theory and Society 24(3): 385-426.

Vasavakul, T. (2014). Authoritarianism Reconfigured: Evolving Accountability Relations within Vietnam's One-Party Rule. Politics in Contemporary Vietnam: Party, State, and Authority Relations. London, Palgrave Macmillan: 42-63.

Vatn, A (2005). Rationality, institutions and environmental policy. Ecological Economics 55: 203-217. 
VEPA (2005). Overview of Wetlands Status in Vietnam Following 15 Years of Ramsar Convention Implementation. Hanoi, Vietnam, Vietnam Environment Protection Agency (VEPA), The World Conservation (IUCN Vietnam), Mekong Wetlands Biodiversity Conservation and Sustainable Use Programme.

VEPA (2007). "The third Vietnam National Report to Convention on Biological Diversity." Retrieved 28/12/2011, from http://www.cbd.int/doc/world/vn/vn-nr03-en.pdf.

Vietnam Fatherland Front (2008) Introduction. Position, Role of Vietnam Fatherland Front in Political System and Society [Online: http://mattran.org.vn/home/gioithieumt/gtc2.htm] (Accessed: 2 February 2016)

Vietnam Forestry Administration (2014). Report on work of forest protection and management 2014 and direction for 2015. 683/BC-KL-QLR. V. A. o. Forestry. Hanoi, Vietnam. No. 683/BC-KL-QLR.

Vietnam Government (1986). Regulations on three types of forests: production forests, protection forests, and special-use forests. V. M. o. Forestry. Decree 1171-QD.

Vietnam Government (2001). Decision 08/2001/QĐ-T'Tg dated 11/01/2001 of Prime Minister on Issuing Regulations on Management of Special-Use Forests, Environmental Protection Forests and Natural Production Forests. Vietnam Government. Hanoi, Vietnam. No. 08/2001/QD-TTg.

Vietnam Government (2003). Decision 192/2003/QĐ-TTg dated 17/09/2003 of Prime Minister on Ratification of Strategies for the Management of the Vietnamese system of Nature Reserves upto 2010. Vietnam Government. Hanoi, Vietnam. No. 192/2003/QD-TTg.

Vietnam Government (2003). Decision of the Prime Minister to Approve the Management Strategy for a Protected Area System in Vietnam to 2010. No.192/2003/QD-TTg. V. Government. Hanoi. No.192/2003/QD-TTg.

Vietnam Government (2010). Decree 117/2010/ND-CP on Special Use Forest Organization and Management. No.117/2010/ND-CP. Vietnam Government. Hanoi, Vietnamese Government. No.117/2010/ND-CP.

Vietnam Government (2012). Decree 12/2012/NĐ-CP dated 01/03/2012 of Vietnam Government on Registration and Operation Management for NGOs in Vietnam. Vietnam Government. Hanoi, Vietnam. No. 12/2012/ND-CP. 
Vietnam Government (2013). Decision No. 40/2013/QD-T'Tg dated 10/07/2013 of Prime Minister on promulgating the national program on promotion and mobilization of foreign non-governmental aid during 2013-2017. Vietnam Government. Hanoi, Vietnam. N0.40/2013/QD-T'Tg.

Vietnam Government (2014). Decision 218/2014/QĐ-TTg of Prime Minister on Ratification of Vietnam Strategy for Management of Special-Use Forest System, Marine Protected Areas, Inland Wetlands upto 2020 and a vision for 2030. Vietnam Government. Hanoi, Vietnam. Decision 218/2014/QD-TTg.

Vietnam National Assembly (2007). Ordinance 34/2007/PL-UBTVQH11 dated 20/04/2007 of Vietnam National Assembly on the Implementation of Democracy at communes, wards, and towns. Vietnam National Assembly. Hanoi, Vietnam. 34/2007/PL-UBTVQH11.

Vignola, R., T.L. McDaniels and R.W. Scholz (2013). Governance structures for ecosystembased adaptation: Using policy-network analysis to identify key organizations for bridging information across scales and policy areas. Environmental Science \& Policy, 31, 71-84.

Vijge, M.J. (2016). Carbonizing forest governance: Analyzing the consequences of REDD+ for multilevel forest governance. PhD thesis, Wageningen UR, The Netherlands.

VNGO\&CC, CCWG, SRD and Care (2013). Experience of Non-Governmental Organizations in Vietnam in Responding to Climate Change: A Summary. NGO\&CC and CCWG: 46.

VNPPA (2015) Organization Introduction. VNPPA [Online: http:/ /www.vnppa.org.vn/?m=news\&a=page_top\&levelone=29\&lang=en\&idleft $=2$ ] (Accessed: 14 July 2015)

Vu Van Dung, T.Q.B., Tran Lien Phong (2002). Project on enhancing the management of Vietnam protected area system: Draft report on suggesting categories of Vietnam protected areas Hanoi, Vietnam Forestry Protection Department.

VUFO-NGO Resource Center (2013). INGO talking points at Vietnam Development Partnership Forum 2013. Hanoi, Vietnam, VUFO-NGO Resource Centre.

VUSTA (2012). Capacity enhancement for civil society organisations on VPA/FLEGT, Thiennhien.net. 
Wallace, C. (2009). "Optimising horizontal and vertical partnership connections: bringing partnerships together to create a network advantage." Australian Journal of Primary Health 15: 196-202.

Watson, A. (2013). "Misunderstanding the "nature" of co-management: A geography of regulatory science and indigenous knowledge (IK)." Environmental Management 52: 1085-1102

West, P., J. Igoe and D. Brockington (2006). "Parks and Peoples: The social impact of protected areas." Annual Review of Anthropology 35: 251-277.

Westley, F. and H. Vredenburg (1991). Strategic bridging: the collaboration between environmentalists and business in the marketing of green products, Journal of Applied Behavioral Science 27(1): 65-90.

Westley, F.R., O. Tjornbo, L. Schultz, P. Olsson, C. Folke, B. Crona and Ö. Bodin (2013). A theory of transformative agency in linked social-ecological systems. Ecology and Society, 18(3), 27 [online: http://www.ecologyandsociety.org/vol18/iss3/art27/]

Wilson, D.C., M. Ahmed, S.V. Siar and U. Kanagaratnam (2006). "Cross-scale linkages and adaptive management: Fisheries co-management in Asia.” Marine Policy 30: 523-533.

Wischermann, J. (2010). "Civil Society Action and Governance in Vietnam: Selected Findings from an Empirical Survey "Journal of Current Southeast Asian Affairs 29(2): 3-40.

Wischermann, J. (2011). "Governance and Civil Society Action in Vietnam: Changing the Rules from Within - Potentials and Limits.” Asian Politics \& Policy 3(3): 383-411.

Worster, D. (1994). Nature's economy: a history of ecological ideas, Cambridge University Press.

Wunder, S., B.T. Dung and E. Ibarra (2005). Payment is good, control is better: why payments for forest environmental services in Vietnam have so far remained incipient. Bogor, Indonesia, CIFOR

Wyatt, A.B. and L.T. Quan (2007). Evaluation report: sustainable livelihoods and participatory wetlands conservation in the plain of reeds, CARE.

Wyatt, A.B., D.T. Ha and N.T.P. Thao (2011). Center for Marinelife Conservation and Community Development: Supporting Poor Vietnamese Coastal Communities in Advancing Sustainable Livelihoods and Conserving the Environment. Unpublished document 
Yin, R. K. (2013). Case study research: Design and methods, Sage publications.

Zingerli, C. (2005). "Colliding Understandings of Biodiversity Conservation in Vietnam: Global Claims, National Interests, and local Struggles.” Society \& Natural Resources 18(8): 733-747. 


\section{APPENDICES}

Appendix 1. Questionnaire for cross-national survey on Special Use Forest Management

\section{PART 1. AREA}

1. Which of the following international conventions have your protected area ever worked with?

\begin{tabular}{l|l|l}
$\square$ The World Heritage Convention & $\square$ CITES & $\square$ ASEAN Agreement on Natural \\
$\square$ RAMSAR Convention & $\square$ Convention on Biological Diversity & Conservation and Natural Resources \\
$\square$ MARPOL Convention & $\square$ Cartagena Protocol on Bio-safety & $\square$ Others, please specify:
\end{tabular}

2. What is the priority for your protected area? (Please mark (x) only one appropriate box)

\begin{tabular}{l|l|l}
\hline Rehabilitation of landscape & $\square$ Rare, Endangered and Endemic & $\square$ Wetland ecosystem protection
\end{tabular}

\begin{tabular}{l|l}
$\square$ Livelihood support & $\begin{array}{l}\text { species protection } \\
\square \text { Forest ecosystem protection }\end{array}$
\end{tabular}$\square$ Others, please specify:

3. What has been the mostly facilitating thing to the management of your protected area for the last five years? (Please mark (x) only one appropriate box)

\begin{tabular}{l|l|l}
$\begin{array}{l}\square \text { More international cooperation } \\
\begin{array}{l}\square \text { More attention from government } \\
\text { on nature conservation }\end{array}\end{array}$ & $\begin{array}{l}\square \text { More local people cooperation } \\
\square \text { More authority for the protected } \\
\text { area }\end{array}$ & $\square$ Others, please specify: \\
\hline 4 .
\end{tabular}

4. What are the external threats to your protected area? (You may choose more than one by marking ( $\mathbf{x}$ ) appropriate boxes)

\begin{tabular}{l|l|l}
$\begin{array}{l}\square \text { Farming land expansion } \\
\begin{array}{l}\text { Wildlife trade } \\
\square \text { Environmental population }\end{array}\end{array}$ & $\begin{array}{l}\square \text { Infrastructure construction } \\
\square \text { Tourism }\end{array}$ & $\begin{array}{l}\square \text { Mining } \\
\square \text { Others, please specify: }\end{array}$
\end{tabular}

5. What is the biggest constraint you are facing in operating the management of the protected area? (Please mark $(x)$ only one appropriate box)

\begin{tabular}{|c|c|c|}
\hline $\begin{array}{l}\square \text { Staff capacity } \\
\square \text { Equipment }\end{array}$ & $\begin{array}{l}\square \text { Constraints related to policy } \\
\square \text { Lack of data on natural resources }\end{array}$ & $\begin{array}{l}\square \text { Lack of fund } \\
\square \text { Others, please specify: }\end{array}$ \\
\hline
\end{tabular}

6. If your staff need to be trained to implement the collaboration in protected area management, which of the following do you think they would need most? (Please mark (x) only one appropriate box)

\begin{tabular}{l|l|l}
$\square$ Project/plan setting & $\square$ Persuation to convince for & $\square$ Knowledge of ecosystem \\
$\square$ Ecotourism business & collaboration \\
$\square$ Information dissemination & $\begin{array}{l}\square \text { Report writing } \\
\square \text { Policy implementation and } \\
\text { enforcement }\end{array}$ & $\begin{array}{l}\square \text { Indigenous knowledge on natural } \\
\text { resource management } \\
\square \text { Others, please specify: }\end{array}$
\end{tabular}

7. Please list maximum five international organizations do you have collaboration with and mention their role as well as the year you had that collaboration.

\begin{tabular}{|l|l|l|}
\hline Year & Sponsor & Technical assistant \\
\hline
\end{tabular}




\begin{tabular}{|c|c|c|c|c|}
\hline \multicolumn{3}{|l|}{$\begin{array}{l}1 . \\
2 . \\
3 . \\
4 . \\
5 .\end{array}$} & & \\
\hline \multicolumn{5}{|c|}{$\begin{array}{l}\text { Please give your opinion about the following management issues related to your protected } \\
\text { area. Please mark }(x) \text { your choice }\end{array}$} \\
\hline \multicolumn{5}{|c|}{$\begin{array}{l}\text { 8. The collaboration between different levels and your protected area is the best mechanism to } \\
\text { manage the area in present context of social-economic development. }\end{array}$} \\
\hline$\square$ Strongly agree & $\square$ Agree & $\square$ Neutral & $\square$ Disagree & $\square$ Strongly disagree \\
\hline \multicolumn{5}{|c|}{$\begin{array}{l}\text { 9. The collaboration between your protected area and different social and economic sectors from } \\
\text { national and international levels is the best mechanism to manage the area in present context of } \\
\text { social-economic development. }\end{array}$} \\
\hline$\square$ Strongly agree & $\square$ Agree & $\square$ Neutral & $\square$ Disagree & $\square$ Strongly disagree \\
\hline \multicolumn{5}{|c|}{$\begin{array}{l}\text { 10. The leaders of your protected area are proactively searching for new collaboration with other } \\
\text { partners to manage the area }\end{array}$} \\
\hline$\square$ Strongly agree & $\square$ Agree & $\square$ Neutral & $\square$ Disagree & $\square$ Strongly disagree \\
\hline \multicolumn{5}{|c|}{$\begin{array}{l}\text { 11. The experience in collaboration in the protected area management have been documented by } \\
\text { the Board of protected area management }\end{array}$} \\
\hline$\square$ Strongly agree & $\square$ Agree & $\square$ Neutral & $\square$ Disagree & $\square$ Strongly disagree \\
\hline \multicolumn{5}{|c|}{ 12. When you collaborate with other sectors, the cost for managing the protected area is less } \\
\hline$\square$ Strongly agree & $\square$ Agree & $\square$ Neutral & $\square$ Disagree & | $\triangle$ Strongly disagree \\
\hline \multicolumn{5}{|c|}{$\begin{array}{l}\text { 13. What kinds of projects are being implemented in collaboration with local people and/or with } \\
\text { other organizations. (Please mark }(x) \text { appropriate place in the box below. You may list more than } \\
\text { one) }\end{array}$} \\
\hline \multicolumn{2}{|c|}{ Projects } & $\begin{array}{l}\text { With international } \\
\text { organisation/NGOs }\end{array}$ & With domestic organisations & With local people \\
\hline \multicolumn{2}{|c|}{$\begin{array}{ll}\text { 1. } & \text { Forest ranging } \\
\text { 2. } & \text { Plantation } \\
\text { 3. } & \text { Awareness raising } \\
\text { 4. } & \text { NTFP harvesting } \\
\text { 5. } & \text { Ecotourism } \\
\text { 6. } & \text { Others, please specify: }\end{array}$} & & & \\
\hline \multicolumn{5}{|l|}{ PART II. POLICY } \\
\hline \multicolumn{5}{|c|}{$\begin{array}{l}\text { 14. Please list three governmental policies regulating you to run your protected area in form of } \\
\text { cooperation with other organizations and/or local people. }\end{array}$} \\
\hline $\begin{array}{l}1 . \\
2 . \\
3 .\end{array}$ & & & & \\
\hline \multicolumn{5}{|c|}{$\begin{array}{l}\text { Please give your opinion about the following policy issues related to the management of } \\
\text { your protected area. Please mark }(x) \text { your choice }\end{array}$} \\
\hline \multicolumn{5}{|c|}{ 15. All stakeholders recognize the existence of the relevant policies } \\
\hline$\square$ Strongly agree & $\square$ Agree & $\square$ Neutral & $\square$ Disagree & $\square$ Strongly disagree \\
\hline
\end{tabular}


Strongly agree

17. The state policy has recognized rights of local people to benefit from the protection of your protected area

\begin{tabular}{|l|l|l|l|l}
$\square$ Strongly agree & $\square$ Agree & $\square$ Neutral & $\square$ Disagree & $\square$ Strongly disagree
\end{tabular}

18. The state policy has recognized the historical values and customs of indigenous people on harvesting and using natural resources

\begin{tabular}{|l|l|l|l|l}
$\square$ Strongly agree & $\square$ Agree & $\square$ Neutral & $\square$ Disagree & $\square$ Strongly disagree
\end{tabular}

19. The state government have adequately evaluated the extent to which the policies are applicable to the site

\begin{tabular}{|l|l|l|c|c}
$\square$ Strongly agree & $\square$ Agree & $\square$ Neutral & $\square$ Disagree & $\square$ Strongly disagree
\end{tabular}

20. There is a need for more guidelines from state government on how to cooperate with other sectors in managing the protected area

\begin{tabular}{|l|l|c|c|c}
$\square$ Strongly agree & $\square$ Agree & $\square$ Neutral & $\square$ Disagree & $\square$ Strongly disagree
\end{tabular}

21. There is a lack of incentive policies (such as contracts, credits, loans for revenue-generating investments...) to motivate local people to collaborate with you

\begin{tabular}{|l|c|c|c|c}
$\square$ Strongly agree & $\square$ Agree & $\square$ Neutral & $\square$ Disagree & $\square$ Strongly disagree \\
\hline
\end{tabular}

22. The local people cannot learn the policies by themselves, they need to be informed

\begin{tabular}{|c|c|c|c|c|}
\hline$\square$ Strongly agree & $\square$ Agree & $\square$ Neutral & $\square$ Disagree & $\square$ Strongly disagree \\
\hline
\end{tabular}

23. There is a need for improving financial arrangements to effectively support your protected area operation

\begin{tabular}{|l|l|l|l|l}
$\square$ Strongly agree & $\square$ Agree & $\square$ Neutral & $\square$ Disagree & $\square$ Strongly disagree \\
\hline
\end{tabular}

24. There is a need for devolving more authorities to your management board to improve effectively the management of the area

\begin{tabular}{|c|c|c|c|c|}
\hline$\square$ Strongly agree & $\square$ Agree & $\square$ Neutral & $\square$ Disagree & $\square$ Strongly disagree \\
\hline
\end{tabular}

25. Please mark (x) the stakeholders you have formal collaboration (contracts, regulations, agreements...) or informal collaboration (without official documents) on using and/or managing the protected area.

(Civil organizations such as Youth Union, Farmer Union, Women Association, Veteran's Association)

\begin{tabular}{|ll|l|l|l|}
\hline \multicolumn{1}{|c|}{ Stakeholders } & \multicolumn{1}{|c|}{$\begin{array}{c}\text { Formal } \\
\text { collaboration }\end{array}$} & $\begin{array}{c}\text { Informal } \\
\text { collaboration }\end{array}$ & Content of collaboration \\
\hline 1. & Local people & & \\
2. & Private companies & & \\
3. & State-own companies & & \\
4. & International organizations & & \\
5. & Research and Education Institutes & & \\
6. & Civil organizations & & \\
7. & Military & & \\
8. & Police & & \\
9. & Vietnamese Fatherland Front & & & \\
\hline
\end{tabular}


10. Governments of adjacent provinces

11. Governments of adjacent countries

12. Others, please specify:

26. Which of the following tasks do your organization and others involve in planning and operating the collaboration on protected area management? Please circle your choice.

Notes:

- Write (1) for actors who play the role of leadership by providing guidelines and make final decisions

- Write (2) for actors who take parts in the activities and contribute ideas, information

- Leave it blank for actors who do not participate in any activity"

Tasks:
(a) Resource estimation
(b) Access rights formulation (c)
(d) Market regulation formulation (e) Monitoring
(c) Harvesting regulation formulation

(g) Evaluation

(h) Modifications

\begin{tabular}{|c|c|c|c|c|c|c|c|c|}
\hline Stakeholders & (a) & (b) & (c) & (d) & (e) & (f) & (g) & (h) \\
\hline $\begin{array}{l}\text { 1. } \text { Local people } \\
\text { 2. Private companies } \\
\text { 3. State-own companies } \\
\text { 4. International organizations } \\
\text { 5. Research and Education Institutes } \\
\text { 6. Civil organizations } \\
\text { 7. Military } \\
\text { 8. Police } \\
\text { 9. Vietnamese Fatherland Front } \\
\text { 10. Governments of adjacent provinces } \\
\text { 11. Governments of adjacent countries } \\
\text { 12. Commune People's Committee } \\
\text { 13. District People's Committee } \\
\text { 14. Provincial People's Committee } \\
\text { 15. Central Government }\end{array}$ & & & & & & & & \\
\hline
\end{tabular}

27. If you would like to strengthen the cooperation with government in different levels, which of the following levels would you mostly want to have stronger cooperation with and explain why for your choice. (Please choose only one appropriate box)

\begin{tabular}{l|l|l}
$\square$ Commune People's Committee & $\square$ Provincial People's Committee & Please explain why for your choice: \\
$\square$ District People's Committee & $\square$ Central government &
\end{tabular}

28. If you would like to strengthen the cooperation with other sectors, which of the following sectors would you mostly want to have stronger cooperation with and explain why for your choice. (Please choose only one appropriate box)

\begin{tabular}{|c|c|c|}
\hline $\begin{array}{l}\square \text { Local people } \\
\square \text { Private companies } \\
\square \text { State-own companies } \\
\square \text { International organizations }\end{array}$ & $\begin{array}{l}\square \text { Research and Education Institutes } \\
\square \text { Civil organizations } \\
\square \text { Military } \\
\square \text { Police }\end{array}$ & $\begin{array}{l}\square \text { Vietnamese Fatherland Front } \\
\square \text { Governments of adjacent provinces } \\
\square \text { Governments of adjacent countries } \\
\square \text { Others, please specify: }\end{array}$ \\
\hline \multicolumn{3}{|c|}{ Please explain why for your choice: } \\
\hline \multicolumn{3}{|c|}{$\begin{array}{l}\text { 29. How can the information and feedback from the protected area management usually be } \\
\text { exchanged between stakeholders? (You may choose more than one) }\end{array}$} \\
\hline $\begin{array}{l}\square \text { Monthly report } \\
\square \text { Quarterly report }\end{array}$ & \begin{tabular}{|l|}
$\square$ Meetings, conferences \\
$\square$ Site visits \\
\end{tabular} & \begin{tabular}{|l|}
$\square$ Telephone calls \\
$\square$ Other, please specify:
\end{tabular} \\
\hline
\end{tabular}


30. How often do you have meetings with other stakeholders? (You may choose more than one)

\begin{tabular}{l|l|l}
$\begin{array}{l}\square \text { More than } 12 \text { meetings per } \\
\text { year } \\
\begin{array}{l}\square \text { Between 7-12 meetings per } \\
\text { year }\end{array}\end{array}$ & $\begin{array}{l}\square \text { Between 4-6 meetings per year } \\
\square \text { Between 1-3 meetings per year }\end{array}$ & $\square$ Others, please specify: \\
\hline
\end{tabular}

31. What are usually the meetings for? (You may choose more than one)

\begin{tabular}{|c|c|c|}
\hline $\begin{array}{l}\square \text { Proposing plans of using and } \\
\text { managing natural resources } \\
\square \text { Informing stakeholders new } \\
\text { policies } \\
\square \text { Making important decisions on } \\
\text { using and managing natural }\end{array}$ & $\begin{array}{l}\square \text { Solving conflicts among stakeholders } \\
\square \text { Evaluating the results of the } \\
\text { cooperation } \\
\square \text { Consulting stakeholders about natural } \\
\text { resource use and management }\end{array}$ & $\square$ Others, please specify: \\
\hline
\end{tabular}

32. If you find a need to amend the management and report to the authority responsible for your protected area, how does the authority mostly react to your report?

\begin{tabular}{l|l|l|}
$\begin{array}{l}\square \text { Guide you in more specific } \\
\text { details without changing in the } \\
\text { policies }\end{array}$ & $\begin{array}{l}\square \text { Make modifications on the policies } \\
\square \text { Not respond }\end{array}$ & $\square$ Others, please specify: \\
$\begin{array}{l}\square \text { Report the issue to higher level } \\
\text { of government }\end{array}$ & & \\
\hline
\end{tabular}

33. How long does it take the authority resposible for your protected area to respond to your requests in amending policies?

\begin{tabular}{|l|l|l}
\hline $\begin{array}{l}\square \text { Less than } 3 \text { months } \\
\square \text { 3-6 months }\end{array}$ & $\square$ 7-12 months \\
$\square$ 13-24 months
\end{tabular}

34. If you find a new situation emerging in management of the protected area, for instance, new conflicts among stakeholders, what will you do to tackle that one? Please choose one

$\square$ Report to responsible
authority and wait for guidelines
$\square$ Try to solve by yourself and
report your solution to the
authority

\begin{tabular}{|l|l}
\hline Make the proposal by yourself for solving & $\square$ Do nothing \\
the situation and send to authority for & $\square$ Others, please specify:
\end{tabular} approval

$\square$ Discuss with other organisations and local people to find solutions and implement them without the participation of government

Please give your opinion about the following social issues related to the context of your protected area. Please mark $(x)$ your choice

35. Poor education is the most important constraint influencing local people to change their behavior in taking parts in managing the protected area

\begin{tabular}{|l|l|l|l|l}
$\square$ Strongly agree & $\square$ Agree & $\square$ Neutral & $\square$ Disagree & $\square$ Strongly disagree \\
\hline
\end{tabular}

36. Some groups of people cannot cooperate with because of their historic value and customs on using and managing natural resources

\begin{tabular}{|c|c|c|c|c|}
\hline$\square$ Strongly agree & $\square$ Agree & $\square$ Neutral & $\square$ Disagree & $\square$ Strongly disagree \\
\hline \multicolumn{5}{|c|}{$\begin{array}{l}\text { 37. Your protected area is now managed via the mechanism of co-management and please } \\
\text { explain why for your choice. }\end{array}$} \\
\hline$\square$ Strongly agree & $\square$ Agree & $\square$ Neutral & $\square$ Disagree & $\square$ Strongly disagree \\
\hline \multicolumn{5}{|c|}{ Explain why for your choice: } \\
\hline IV. GENERAL II & MATIO & & & \\
\hline
\end{tabular}


Please provide the following general information about you and your protected area. All personal information will be confidential

38. General information on the respondant

1. Position in the protected area:

2. Date of response:

3. Email address:

4. Telephone number:

39. General information on the protected area

1. Name of the protected area:

2. Location (provinces): 


\section{Appendix 2. Questions guiding for interviews with local people}

1. What natural resources of the protected area do you and your family depends on or exploits?

2. Did you voluntarily register for the involvement in managing and protecting the natural resources or are you invited or maneuvered?

3. What do you expect most when getting involved in managing and protecting the natural resources?

4. Description of your work in the involvement in managing and protecting the natural resources

+ What do you do?

+ Who do you work with?

+ What time do you carry out the work?

5. Working with other local people in the community

+ How do they collaborate with you in managing and protecting the natural resources?

+ How and when do you communicate with them?

+ Do you find any constraint when contacting or communicating with them?

6. Working with staffs of the protected area

+ How do staffs of the protected area collaborate with you in managing and protecting the natural resources?

+ How and when do you communicate with them?

+ Do you find any constraint when contacting or communicating with them?

7. Working with Commune government

+ How does Commune government collaborate with you in managing and protecting the natural resources?

+ How and when do you communicate with them?

+ Do you find any constraint when contacting or communicating with them?

8. Working with forest rangers

+ How do forest rangers collaborate with you in managing and protecting the natural resources?

+ How and when do you communicate with them?

+ Do you find any constraint when contacting or communicating with them?

9. Working with public security

+ How does public security collaborate with you in managing and protecting the natural resources?

+ How and when do you communicate with them?

+ Do you find any constraint when contacting or communicating with them?

10. Working with inspectors of fishery resource protection

+ How do inspectors of fishery resource protection collaborate with you in managing and protecting the natural resources? 
+ How and when do you communicate with them?

+ Do you find any constraint when contacting or communicating with them?

11. Who else do collaborate with you in managing and protecting the natural resources?

+ How and when do you communicate with them?

+ Do you find any constraint when contacting or communicating with them?

12. When carrying out your tasks of natural resource management and protection what do you think about the following aspects in your situation?

+ Knowledge

+ Finance

+ Equipment

+ Collaboration with others

+ Anything else

13. How is your relationship with others?

+ With other local people who also involve in managing and protecting the natural resources

+ With other local people who do not involve in managing and protecting the natural resources

+ With other people outside the community

14. When having concerns and/or ideas related to natural resource management and protection

+ Who do you discuss with?

+ Do your concerns and/ or ideas heard or responded? Please give an example

15. What are changes in your life when getting involved in managing and protecting the natural resources?

+ About your income, is it increased or decreased or the same as before getting involved?

+ What are other benefits when getting involved in managing and protecting the natural resources?

+ Is there any change in your spiritual life when getting involved?

+ According to you what benefits should be added or improved to help people like you who involving in managing and protecting the natural resources to have a better life?

16. What do you think about advantages and disadvantages of getting more people, more sectors involved in managing and protecting the natural resources?

+ Advantages

+ Disadvantages

17. How can you evaluate the involvement of local people in managing and protecting the natural resources? 


\section{Appendix 3. Questions guiding for interviews with People Committees and other state actors and organisations}

1. What do you think about the roles and positions of the protected area to the socioeconomic life of your area?

2. What are responsibilities and authorities of the People's Committee/your organisation to the protected area management?

3. What are supports of the People's Committee/your organisation to the protected area management?

+ Plans

+ Projects

+ Finance

+ Others

4. What are advantages and disadvantages have you recognized when the People's

Committee/your organisation works with other stakeholders to manage the natural resource of the protected area?

+ Working with the protected area:

- Advantages

- Disadvantages

- Suggestions for improvements

+ Working with local people:

- Advantages

- Disadvantages

- Suggestions for improvements

+ Working with forest rangers

- Advantages

- Disadvantages

- Suggestions for improvements

+ Working with inspectors of fishery resource protection

- Advantages

- Disadvantages

- Suggestions for improvements

+ Working with border guards

- Advantages

- Disadvantages

- Suggestions for improvements

+ Working with tourist enterprises

- Advantages

- Disadvantages

- Suggestions for improvements 
+ Working with foreigners

- Advantages

- Disadvantages

- Suggestions for improvements

+ Working with higher authorities

- Advantages

- Disadvantages

- Suggestions for improvements

+ Working with others

- Advantages

- Disadvantages

- Suggestions for improvements

5. What can you evaluate the capacities of the People's Committee/your organisation in the contribution to the protected area management?

+ Knowledge

+ Finance

+ Personnel

+ Equipment

+ Collaboration

+ Others

6. What can you evaluate the capacities in the collaboration of other stakeholders in the protected area management?

+ Local people

+ Staffs of the protected area

+ Forest Rangers

+ Department of fishery resource protection

+ Border guards

+ Enterprises

+ Others

7. According to you what should be done to improve the collaboration among the People's Committee/your organisation, local people, the protected area, higher authorities and other stakeholders in the protected area management? 


\section{Appendix 4. Questions guiding for interviews with NGOs}

1. From local to central, which level of government does your organisation mostly focus to work with? And why?

+ Issues of your collaboration

+ Advantages and disadvantages in your collaboration (procedures, capacities, proactiveness and responsiveness, others)

+ Approach used for your communication and negotiation (documents, workshops, meetings, phone calls, emails...)

+ Reactions to your recommendations

2. How do you collaborate with protected areas? And other state actors?

+ Issues of your collaboration

+ Advantages and disadvantages in your collaboration (procedures, capacities, proactiveness and responsiveness, others)

+ Approach used for your communication and negotiation (documents, workshops, meetings, phone calls, emails...)

+ Reactions to your recommendations

3. How do you perceive roles of civil organisations in nature conservation of Vietnam?

4. How do your collaborate with universities and research institutes in nature conservation? And enterprises?

+ Types of universities/enterprises

+ Issues of collaboration

+ Advantages and disadvantages in the collaboration

5. How do you collaborate with local communities?

6. Do you support local engagement in nature conservation? And why?

7. What do perceive of local communities in terms of

+ Their knowledge on nature conservation

+ Their commitments on laws and models of participatory nature conservation

+ Their culture

+ Their innovation capacities

+ Proactiveness and enthusiastism

8. What is your general evaluation about the participation of communities in nature conservation?

9. What are your opinions about the Vietnamese policies on mobilising a diversity of actors involved in protected area management? What are their strengths and weaknesses? 


\section{Appendix 5.. A summary of responsibilities and authorities of actors in SUF management}

\begin{tabular}{|c|c|c|}
\hline Actors & Responsibilities and authorities & $\begin{array}{l}\text { Legal document } \\
\text { mentioned }\end{array}$ \\
\hline \multicolumn{3}{|c|}{ Central level } \\
\hline$\stackrel{\theta}{2}$ & $\begin{array}{l}\text { - Organising SUF management, constructing strategies of, and } \\
\text { planning on forest protection and development } \\
\text { Directing and instructing PPCs and SUF management boards to } \\
\text { implement SUF laws, inventory, boundary definition, new } \\
\text { mechanism pilots, allocation, checking and monitoring, financial } \\
\text { supports, and information dissemination } \\
\text { - Ratifying master plans and programs on SUF establishment and } \\
\text { investment } \\
\text { Receiving documents of appeals and complaints during processes of } \\
\text { SUF legal document implementation }\end{array}$ & $\begin{array}{l}\text { Law on Fisheries 2003; } \\
\text { Decree 109/2003/ND- } \\
\text { CP; Decision } \\
\text { 192/2003/QD-TTg; Law } \\
\text { on Forest Protection and } \\
\text { Development 2004; } \\
\text { Decision 62/2005/QD- } \\
\text { BNN; Decision } \\
\text { 1174/2005/QD-TTg; } \\
\text { Decision 106/2006/QD- } \\
\text { BNN; Circular } \\
\text { 70/2007/TT-BNN; } \\
\text { Decision 104/2007/QD- } \\
\text { BNN; Decision } \\
\text { 2740/2007/QD-BNN- } \\
\text { KL; Circular } \\
\text { 22/2007/TTLT-BNN- } \\
\text { BNV; Decision } \\
\text { 2370/2008/QD-BNN- } \\
\text { KL; Decree } \\
\text { 99/2010/ND-CP; Decree } \\
\text { 117/2010/ND-CP; } \\
\text { Decision 262/2010/QD- } \\
\text { TCLN-KL; Circular } \\
\text { 78/2011/TT-BNNPTNT }\end{array}$ \\
\hline 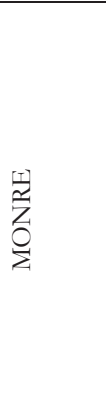 & $\begin{array}{l}\text { - Implementing SUF lands, master plans, and plans on SUF } \\
\text { protections and development } \\
\text { - Checking policy and legal document implementation on wetland } \\
\text { preservation and management across the country } \\
\text { - Coordinating and hosting provincial governmental organisations to } \\
\text { allocate forests, withdraw allocated forests, modify landuse directions } \\
\text { and rights, check and monitor status quos of wetland management to } \\
\text { make adjustment on time } \\
\text { Receiving documents of appeals and complaints during processes of } \\
\text { SUF legal document implementation and solve the problems } \\
\text { together with other governmental organisations }\end{array}$ & $\begin{array}{l}\text { Decision 192/2003/QD- } \\
\text { TTg; Circular } \\
\text { 18/2004/TT-BTNMT; } \\
\text { Decree 109/2003/ND- } \\
\text { CP; Decision } \\
\text { 1174/2005/QD-TTg; } \\
\text { Decision 04/2004/QD- } \\
\text { BTNMT }\end{array}$ \\
\hline
\end{tabular}




\begin{tabular}{|c|c|c|}
\hline 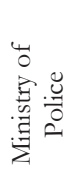 & $\begin{array}{l}\text { - Directing and instructing PPCs in forestfire precaution and fighting } \\
\text { - Directing, instructing, and training forces of forest rangers and local } \\
\text { forces of inter-sectors to against violations of SUF laws } \\
\text { - Investigating or receiving local cases of SUF law violations and } \\
\text { providing with measurements }\end{array}$ & $\begin{array}{l}\text { Law on Forest Protection } \\
\text { and Development } 2004\end{array}$ \\
\hline 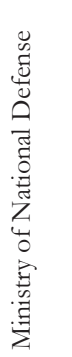 & $\begin{array}{l}\text { - Managing and directing army forces and PPCs to implement their } \\
\text { assigned SUF protection, management and development. } \\
\text { - Directing and guiding local defense forces to SUFs patrols, forestfire } \\
\text { fights, and protection } \\
\text { - Supporting and collaborating with local forest ranger forces } \\
\text { - Organising information dissemination and boosting local } \\
\text { engagement in SUF protection }\end{array}$ & $\begin{array}{l}\text { Law on Forest Protection } \\
\text { and Development (2004); } \\
\text { Direction 45/2007/CT- } \\
\text { BNN; Circular } \\
\text { 98/2010/TTLT-BQP- } \\
\text { BNNPTNT; Decree } \\
\text { 74/2010/ND-CP; } \\
\text { Decision 07/2012/QD- } \\
\text { TTg }\end{array}$ \\
\hline 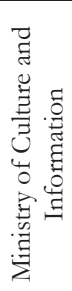 & $\begin{array}{l}\text { Directing and instructing PPCs to organise forest protection relating } \\
\text { to cultural heritages and remains } \\
\text { - Directing centers for culture to implement dissemination on SUF } \\
\text { conservation, monitor and take responsibilities while carrying out } \\
\text { tourist activities in areas of SUFs } \\
\text { - Establishing tourist plans and implement the plans and tourist } \\
\text { development in SUFs }\end{array}$ & $\begin{array}{l}\text { Law on Forest Protection } \\
\text { and Development 2004; } \\
\text { Decision 04/2004/QD- } \\
\text { BTNMT; Decision } \\
\text { 104/2007/QD-BNN; } \\
\text { Direction 24/1998/CT- } \\
\text { TTg; Decision } \\
\text { 08/2001/QD-TTg }\end{array}$ \\
\hline 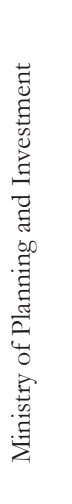 & $\begin{array}{l}\text { - Cooperating with Ministry of Finance to coordinate governmental } \\
\text { budgets, donors, funds to invest in SUF management } \\
\text { - Cooperating with MARD to construct mechanism and policy relating } \\
\text { to SUF management } \\
\text { - Cooperating with MARD and Ministry of Finance to check and } \\
\text { monitor SUF investments } \\
\text { - Instructing provincial governments to ensure budgets for SUF } \\
\text { protection }\end{array}$ & $\begin{array}{l}\text { Decision 08/2001/QD- } \\
\text { TTg; Decision } \\
\text { 192/2003/QD-TTg; } \\
\text { Decision 1174/2005/QD- } \\
\text { TTg; Decree } \\
\text { 117/2010/ND-CP; } \\
\text { Decision 07/2012/QD- } \\
\text { TTg; Decision } \\
\text { 24/2012/QD-TTg; } \\
\text { Decision 1250/2013/QD- } \\
\text { TTg; Decision } \\
\text { 218/2014/QD-TTg; } \\
\text { Decision 1976/2014/QD- } \\
\text { TTg }\end{array}$ \\
\hline
\end{tabular}




\begin{tabular}{|c|c|c|}
\hline 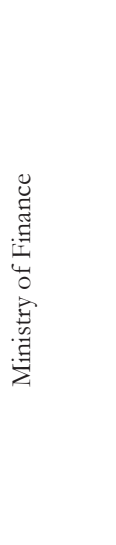 & $\begin{array}{l}\text { - Directing and instructing locals to cooperate with MARD and } \\
\text { Minsitry of Defense to implement payments for costs of mobilising } \\
\text { organisations and individuals engaged in forest protection } \\
\text { - Cooperating with MARD to host and instruct local levels to } \\
\text { implement fund management and expenditure } \\
\text { - Cooperating with Ministry of Science and Technology to construct } \\
\text { and distribute budgets for scientific and technology projects and } \\
\text { programs } \\
\text { Cooperating with MONRE to manage governmentally } \\
\text { environmental protection budgets }\end{array}$ & $\begin{array}{l}\text { Decree 119/2006/ND- } \\
\text { CP; Circular 25/2006/TT- } \\
\text { BTC; Decree } \\
\text { 05/2008/ND-CP; Circular } \\
\text { 01/2008/TT-BTC; Cicular } \\
\text { 58/2008/TTLT-BNN- } \\
\text { KHDT-TC; Decision } \\
\text { 2370/2008/QD-BNN- } \\
\text { KL; Decision } \\
\text { 24/2012/QD-TTg; } \\
\text { Decision 07/2012/QD- } \\
\text { TTg; Decision } \\
\text { 218/2014/QD-TTg; } \\
\text { Decision 1976/2014/QD- } \\
\text { TTg }\end{array}$ \\
\hline 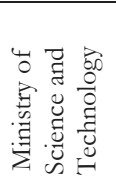 & $\begin{array}{l}\text { - Hosting development of scientific research and programs relating to } \\
\text { natural resource conservation and management }\end{array}$ & $\begin{array}{l}\text { Decision 192/2003/QD- } \\
\text { TTg }\end{array}$ \\
\hline 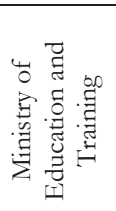 & $\begin{array}{l}\text { - Introducing nature conservation to education systems and outdoor } \\
\text { education programs }\end{array}$ & $\begin{array}{l}\text { Decision 192/2003/QD- } \\
\text { TTg }\end{array}$ \\
\hline \multicolumn{3}{|c|}{ Provincial level } \\
\hline 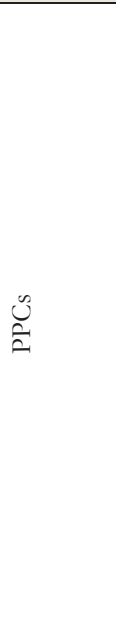 & 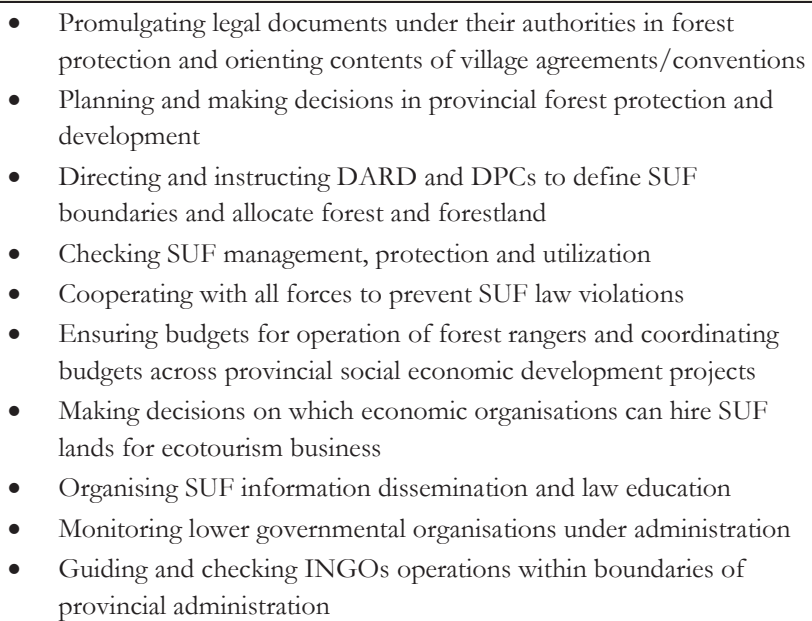 & $\begin{array}{l}\text { Direction 24/1998/CT- } \\
\text { TTg; Law on Forest } \\
\text { Protection and } \\
\text { Development 2004; } \\
\text { Circular 18/2004/TT- } \\
\text { BTNMT; Decision } \\
\text { 1174/2005/QD-TTg; } \\
\text { Decision 2740/2007/QD- } \\
\text { BNN-KL; Decree } \\
\text { 99/2010/ND-CP; Decree } \\
\text { 12/2012/ND-CP; Article } \\
\text { 137 Land Law } 2013\end{array}$ \\
\hline
\end{tabular}




\begin{tabular}{|c|c|c|}
\hline 旁 & $\begin{array}{l}\text { - Directing and instructing functioning organisations to cooperate with } \\
\text { CPCs in terms of working out community forest management, agro- } \\
\text { forestry enhancement, and community supports } \\
\text { - Consulting PPCs with community forest management and } \\
\text { development } \\
\text { - Coordinating SUF projects, master plans, and modifications, and } \\
\text { assessing SUF PES application and implementation }\end{array}$ & $\begin{array}{l}\text { Decision 106/2006/QD- } \\
\text { BNN; Circular } \\
\text { 70/2007/TT-BN; Decree } \\
\text { 99/2010/ND-CP; Decree } \\
\text { 117/2010/ND-CP; } \\
\text { Circular 78/2011/TT- } \\
\text { BNNPTNT }\end{array}$ \\
\hline $\begin{array}{l}\frac{1}{2} \\
\frac{1}{2} \\
0 \\
\text { م. }\end{array}$ & $\begin{array}{l}\text { - Hosting investigation and doing research on wetlands } \\
\text { - Receiving documents relating to SUF mater plans and SUF PES, } \\
\text { assessing them and making relevant modifications }\end{array}$ & $\begin{array}{l}\text { Decree 109/2003/ND- } \\
\text { CP; Circular 78/2011/TT- } \\
\text { BNNPTNT }\end{array}$ \\
\hline 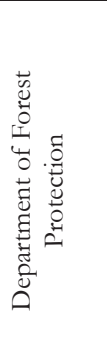 & $\begin{array}{l}\text { - Consulting with authorities in charge of forest protection and law } \\
\text { enforcement } \\
\text { - Directing local forest protection and cooperation of CPCs, } \\
\text { communities, district forest protection units } \\
\text { - Information dissemination and forest protection law education } \\
\text { - Enhancing capacity of forest protection forces } \\
\text { - Applying advanced science and technology into forest ranger } \\
\text { activities }\end{array}$ & $\begin{array}{l}\text { Decree 119/2006/ND- } \\
\text { CP; Decision } \\
\text { 1717/2006/QD-BNN- } \\
\text { KL; Circular } \\
\text { 70/2007/TT-BNN; } \\
\text { Circular 22/2007/TTLT- } \\
\text { BNN-BNV; Direction } \\
\text { 45/2007/CT-BNN; } \\
\text { Circular 61/2007/TTLT- } \\
\text { BNN-BTC }\end{array}$ \\
\hline 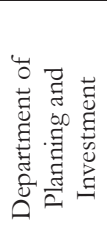 & $\begin{array}{l}\text { - Adjusting and coordinating provincial government budgets } \\
\text { - Consulting with PPC to support, assess, and finalise budgets for } \\
\text { forest protection projects }\end{array}$ & $\begin{array}{l}\text { Circular 58/2008/BNN- } \\
\text { KHDT-BTC }\end{array}$ \\
\hline 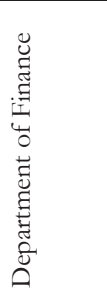 & $\begin{array}{l}\text { - Hosting and coordinating governmental organisations to assess } \\
\text { budgets } \\
\text { - } \quad \text { Reporting forest protection fund management to MARD } \\
\text { - } \quad \text { Finalising provincial forest protection funds }\end{array}$ & $\begin{array}{l}\text { Circular 58/2008/BNN- } \\
\text { KHDT-TC }\end{array}$ \\
\hline & & \\
\hline
\end{tabular}




\begin{tabular}{|c|c|c|}
\hline $\begin{array}{l}3 \\
\hat{0}\end{array}$ & $\begin{array}{l}\text { - Implementing provincial government directions } \\
\text { Instructing commune governments to planning forest allocation, } \\
\text { implementing commune forest protection agreement/convention, } \\
\text { applying technologies, training and educating forest protection laws, } \\
\text { and collaborating with international organisations } \\
\text { - Cooperating with forest rangers, other organisations and forces } \\
\text { across district administration areas to enforce forest protection } \\
\text { - Monitoring, checking and assessing ecotourism activities and } \\
\text { community forest protection activities in SUFs across areas of } \\
\text { district administration } \\
\text { - Implementing PES } \\
\text { Reporting status quos of forest protection and community forest } \\
\text { protection activities to Provincial Department of Forest Protection }\end{array}$ & $\begin{array}{l}\text { Direction 30/1998/CT- } \\
\text { TW; Decision } \\
\text { 08/2001/QD-TTg; Law } \\
\text { on Forest Protection and } \\
\text { Development 2004; } \\
\text { Decision 1174/2005/QD- } \\
\text { TTg; Decision } \\
\text { 106/2006/QD-BNN; } \\
\text { Decree 119/2006/ND- } \\
\text { CP; Decision } \\
\text { 1717/2006/QD-BNN- } \\
\text { KL; Circular } \\
\text { 70/2007/TT-BNN; } \\
\text { Circular 22/2007/TTLT- } \\
\text { BNN-KL; Decree } \\
\text { 117/2010/ND-CP; } \\
\text { Decree 99/2010/ND-CP }\end{array}$ \\
\hline$\stackrel{3}{0}$ & 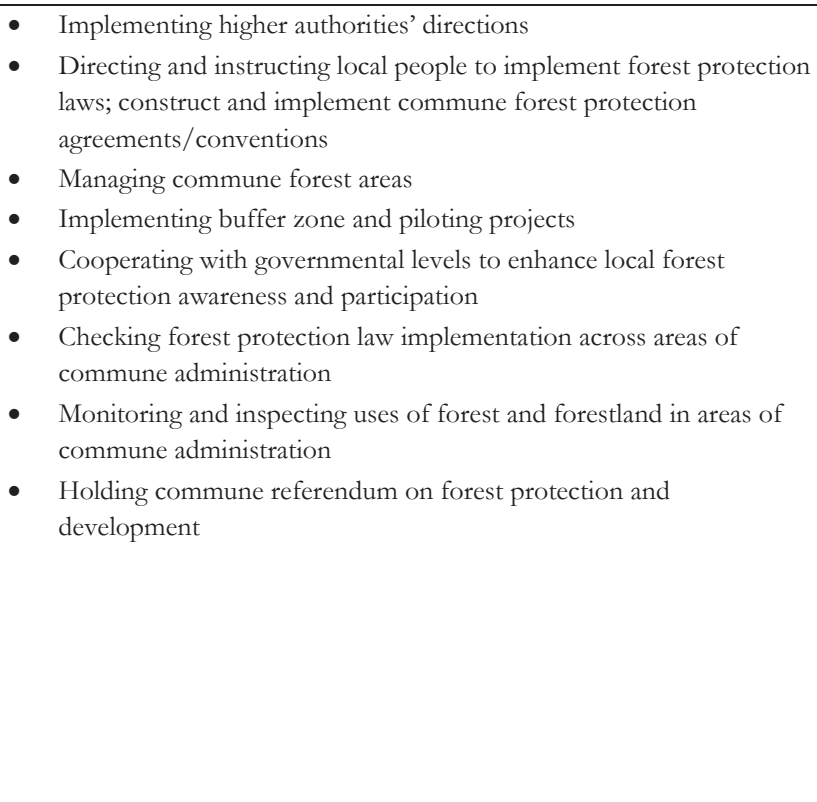 & $\begin{array}{l}\text { Direction 24/1998/CT- } \\
\text { TTg;Decision } \\
\text { 08/2001/QD-TTg; } \\
\text { Decision 192/2003/QD- } \\
\text { TTg; Law on Forest } \\
\text { Protection and } \\
\text { Development 2004; } \\
\text { Decision 1174/2005/QD- } \\
\text { TTg; Decree } \\
\text { 119/2006/ND-CP; } \\
\text { Decision 1717/2006/QD- } \\
\text { BNN-KL; Decision } \\
\text { 104/2007/QD-BNN; } \\
\text { Ordinance 34/2007/PL- } \\
\text { UBTVQH11; Decree } \\
\text { 99/2010/ND-CP; Decree } \\
\text { 117/2010/ND-CP; } \\
\text { Direction 3714/2011/CT- } \\
\text { BNN-TCLN; Decision } \\
\text { 57/2012/QD-TTg; } \\
\text { Decision 126/2012/QD- } \\
\text { TTg }\end{array}$ \\
\hline
\end{tabular}




\begin{tabular}{|c|c|c|}
\hline 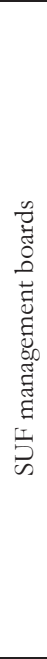 & 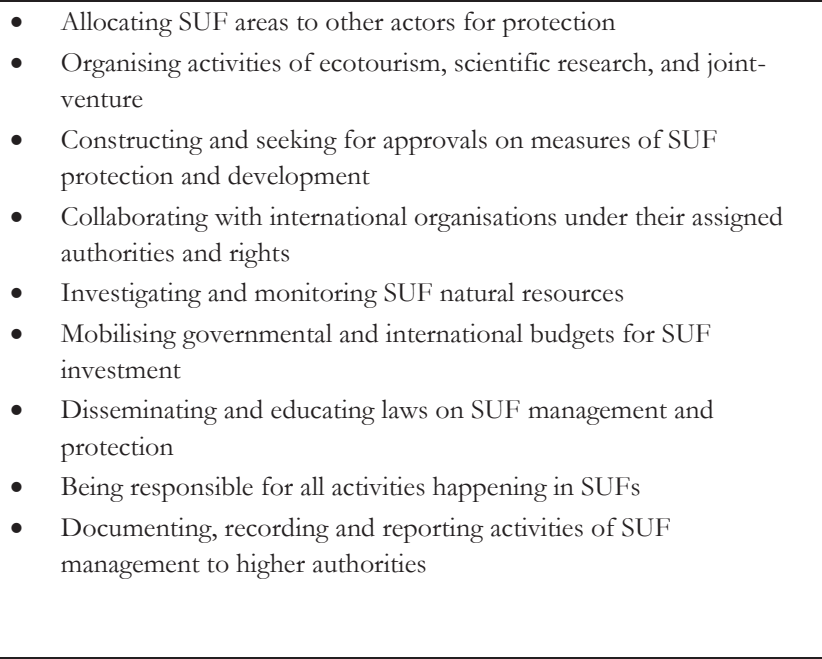 & $\begin{array}{l}\text { Decision 192/2003/QD- } \\
\text { TTg; Circular } \\
\text { 18/2004/TT-BTNMT; } \\
\text { Law on Forest Protection } \\
\text { and Development 2004; } \\
\text { Decision 104/2007/QD- } \\
\text { BNN; Circular } \\
\text { 01/2008/TT-BTC; } \\
\text { Circular 58/2008/TTLT- } \\
\text { BNN-KHDT-TC; } \\
\text { Decision 262/2010/QD- } \\
\text { TCLN-KL; Circular } \\
\text { 78/2011/TT-BNNPTNT; } \\
\text { Decree 117/2010/ND- } \\
\text { CP; Decision } \\
\text { 24/2012/QD-TTg; } \\
\text { Decision 126/2012/QD- } \\
\text { TTg }\end{array}$ \\
\hline 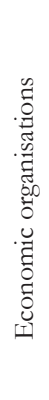 & $\begin{array}{l}\text { - } \\
\text { Exploiting forest products in SUFs under laws } \\
\text { - } \\
\text { - } \quad \text { Using artipating in designing measures for forest protection and } \\
\text { - Participating and implementing mechanism of forest co-management } \\
\text { with local people } \\
\text { Reflecting constraints of regulation implementation processes to } \\
\text { MARD }\end{array}$ & $\begin{array}{l}\text { Decision 08/2001/QD- } \\
\text { TTg; Law on Forest } \\
\text { Protection and } \\
\text { Development 2004; } \\
\text { Circular 58/2008/TTLT- } \\
\text { BNN-KHDT-TC; Decree } \\
\text { 99/2010/ND-CP; Circular } \\
\text { 80/2011/TT-BNNPTNT; } \\
\text { Decision 07/2012/QD- } \\
\text { TTg; Decision } \\
\text { 57/2012/QD-TTg }\end{array}$ \\
\hline 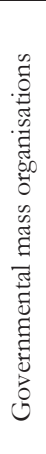 & $\begin{array}{l}\text { - Vietnam Father Front and Youth Union: disseminating and } \\
\text { monitoring local implementation of grassroot democracy; } \\
\text { manoeuvring community participation in SUF protection } \\
\text { - Women Union, Farmer Union, and Youth Union: raising awareness } \\
\text { in SUF protection } \\
\text { - Centers for environmental education and museums: constructing } \\
\text { networks for raising awareness in SUF protection } \\
\text { Education and research organisations: doing research, reporting } \\
\text { research results, paying fees for SUF services, and contributing ideas } \\
\text { for solving SUF management deficiencies } \\
\text { Mass media organisations: disseminating SUF information and } \\
\text { knowledge, and good models of local forest protection }\end{array}$ & $\begin{array}{l}\text { Direction 30/1998/CT- } \\
\text { TW; Direction } \\
\text { 24/1998/CT-TTg; } \\
\text { Decision 192/2003/QD- } \\
\text { TTg; Decision } \\
\text { 04/2004/QD-BTNMT; } \\
\text { Law on Inspection } 2010 \\
\text { (Article 12); Circular } \\
\text { 78/2011/TT-BNNPTNT }\end{array}$ \\
\hline
\end{tabular}




\begin{tabular}{|c|c|c|}
\hline 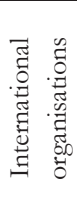 & $\begin{array}{l}\text { - } \\
\text { - } \\
\text { Being compatible with the orientation of Vietnam social economic } \\
\text { development in their activities and operation } \\
\text { - } \quad \text { Sharing and exchanging information with other stakeholders } \\
\text { Reporting their activities to the government }\end{array}$ & $\begin{array}{l}\text { Decree 12/2012/ND-CP; } \\
\text { Decision 40/2013/QD- } \\
\text { TTg }\end{array}$ \\
\hline 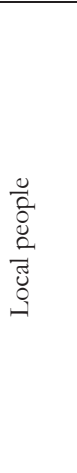 & 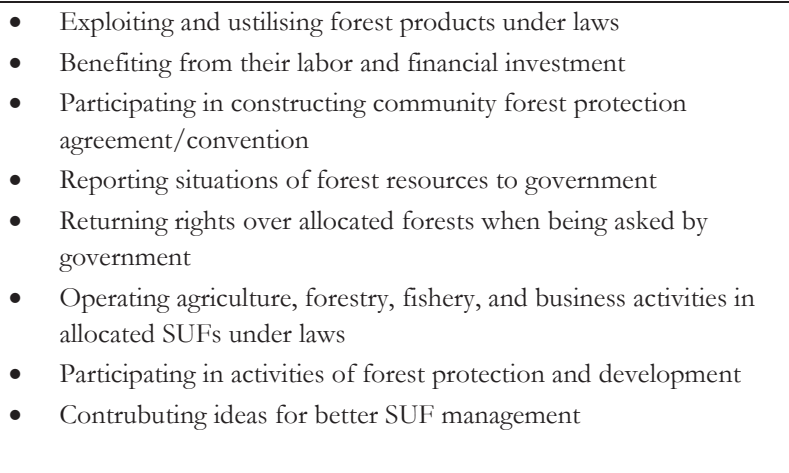 & $\begin{array}{l}\text { Decision 08/2001/QD- } \\
\text { TTg; Decision } \\
\text { 192/2003/QD-TTg; Law } \\
\text { on Forest Protection and } \\
\text { Development 2004; } \\
\text { Circular 18/2004/TT- } \\
\text { BTNMT; Decision } \\
\text { 62/2005/QD-BNN; } \\
\text { Decision 1174/2005/QD- } \\
\text { TTg; Circular } \\
\text { 78/2011/TT-BNNPTNT; } \\
\text { Decision 57/2012/QD- } \\
\text { TTg }\end{array}$ \\
\hline
\end{tabular}


Appendix 6. Questions, weights, means (M) and standard deviation (SD)

\begin{tabular}{|c|c|c|c|c|c|c|c|c|c|c|}
\hline \multirow{2}{*}{\multicolumn{2}{|c|}{ Issue }} & \multirow[t]{2}{*}{ Weight } & \multicolumn{2}{|c|}{$\begin{array}{c}\text { National } \\
\text { Parks } \\
(n=24)\end{array}$} & \multicolumn{2}{|c|}{$\begin{array}{c}\text { Natural } \\
\text { reserves } \\
(n=45)\end{array}$} & \multicolumn{2}{|c|}{$\begin{array}{l}\text { Species or } \\
\text { habitat } \\
\text { reserves } \\
(n=8)\end{array}$} & \multicolumn{2}{|c|}{$\begin{array}{c}\text { Landscape } \\
\text { protected } \\
\text { areas }(n=28)\end{array}$} \\
\hline & & & $M$ & $S D$ & $M$ & $S D$ & $M$ & $S D$ & $M$ & $S D$ \\
\hline \multicolumn{11}{|c|}{ I. Pluralism } \\
\hline 1. & $\begin{array}{l}\text { Who is involved? (Please choose the } \\
\text { stakeholders you have formal (contracts, } \\
\text { regulations, agreements...) or informal } \\
\text { (without official documents) collaborations } \\
\text { with on using and/or managing the protected } \\
\text { area. You may choose more than one option) } \\
\text { 1) Local people } \\
\text { 2) Private companies } \\
\text { 3) State-own companies } \\
\text { 4) International organizations } \\
\text { 5) Research and Education Institutes } \\
\text { 6) Civil organizations (Youth Union, Farmer } \\
\text { Union, Women Association, Veteran's } \\
\text { 7) Mssociation) } \\
\text { 8) Police } \\
\text { 9) Vietnamese Fatherland Front } \\
\text { 10) Governments of adjacent provinces } \\
\text { 11) Governments of adjacent countries } \\
\text { 12) Others, please specify... }\end{array}$ & $100 \%$ & 3.21 & 1.38 & 2.20 & 1.27 & 1.75 & 0.89 & 1.79 & 1.07 \\
\hline \multicolumn{11}{|c|}{$\begin{array}{l}\text { Scoring system: Scores from } 1 \text { to } 5 \text { are judged based on the extent to which a diversity of collaborations between the } \\
\text { management boards and others in terms of both levels (local, regional, national, and international) and scales (enforcement } \\
\text { actors: military, police; information dissemination actors: civil organizations, Vietnamese Fatherland Front; economic actors: } \\
\text { private and state-own companies; science-based actors: research and education institutes; and international actors). }\end{array}$} \\
\hline \multicolumn{11}{|c|}{ II. Communication and Negotiation } \\
\hline 2. & $\begin{array}{l}\text { Is there a need for more guidelines from state } \\
\text { government on how to cooperate with other } \\
\text { sectors in managing the protected area? } \\
\text { 1) Strongly agree } \\
\text { 2) Agree } \\
\text { 3) Neutral } \\
\text { 4) Disagree } \\
\text { 5) Strongly disagree }\end{array}$ & $25 \%$ & 1.58 & .50 & 1.64 & .80 & 1.38 & .51 & 1.74 & .71 \\
\hline 3. & $\begin{array}{l}\text { How can the information and feedback from } \\
\text { the protected area management usually be } \\
\text { exchanged between stakeholders? (You may } \\
\text { choose more than one option) } \\
\text { 1) Monthly reports } \\
\text { 2) Quarterly reports } \\
\text { 3) Meetings and conferences } \\
\text { 4) Telephone calls } \\
\text { 5) Site visits } \\
\text { 6) Others, please specify... }\end{array}$ & $25 \%$ & 4.13 & 1.19 & 4.02 & 1.20 & 2.88 & 1.81 & 3.96 & 1.23 \\
\hline
\end{tabular}


Scoring system: Scores judged from 1 to 5 are based on a diversity in both modes (e.g. paper reports seem to be less interactive than others) and methods (e.g. site visits are closest to operational levels to understand practices) of information and feedback exchange.

4. How often do you have meetings with other $\quad \begin{array}{lllllllll}25 \% & 4.21 & 1.29 & 4.36 & .91 & 4.38 & .74 & 3.25 & 1.43\end{array}$ stakeholders?

1) Between 1 to 3 meetings per year

2) Between 4 to 6 meetings per year

3) Between 7 to 12 meetings per year

4) More than 12 meetings per year

Scoring system: One point is scored for the first option; three points is for the second; four points for the third; and five points for the fourth.

5. What are usually the meetings for? (You may $\quad \begin{array}{lllllllll}25 \% & 4.17 & .87 & 3.78 & .97 & 2.88 & 1.55 & 3.39 & .96\end{array}$ choose more than one option)

1) Proposing plans of using and managing natural resources

2) Informing stakeholders new policies

3) Making decisions on using and managing natural resources

4) Solving conflicts amongst stakeholders

5) Evaluating the results of the cooperation

6) Consulting stakeholders about natural resource use and management

Scoring system: Scores are judged based on the roles of participants and the ways of communications in meetings, e.g. "informing" and "consulting" are one-way communications while others seem to be more interactive; and "making decisions" and "proposing plans" seem to be referred to equal participants in meetings.

\section{Transactive Decision-making}

6. Is there a need for devolving more authorities to your management board to improve effectively the management of the area?

1) Strongly agree

2) Agree

3) Neutral

4) Disagree

5) Strongly disagree

7. If you find a new situation emerging in the management of the protected area, for instance, new conflicts among stakeholders, what will you do to tackle that one?

1) Report to responsible authority and wait for guidelines

2) Try to solve by yourself and report your solution to authority

3) Make a proposal by yourself for solving the situation and send to authority for approval

4) Discuss with other organizations and local people to find solutions and implement them without the participation of government

5) Do nothing 
6) Others, please specify....

Scoring system: Scores are judged based on the degree of freedom of making decisions of SUF managers. One point is for option 5; 2 points for option 1; 3 for option 3; 4 for option 4; and 5 for option 2.

\section{Social-learning}

8. Have the experience in collaboration in the protected area management been documented by the management board of protected area?
1) Strongly disagree
2) Disagree
3) Neutral
4) Agree
5) Strongly agree

9. Has the state government adequately evaluated the extent to which the policies are applicable to the site?

1) Strongly disagree

2) Disagree

3) Neutral

4) Agree

5) Strongly agree

10. If you find a need to amend the management and report to the authority responsible for your protected area, how does the authority mostly react to your report?
1) Guide you in more details without changing in the policies
2) Report the issue to higher level of government
3) Make modifications on the policies
4) Not respond
5) Others, please specify....

Scoring system: Scores are judged based on the extent to which the authority respond to the site. One point is for option 4; 2 points for option 2; 3 points for option 1; and 5 points for option 3.

11. How long does it take the authority $\quad 25 \% \quad \begin{array}{llllllll}4.58 & .72 & 4.02 & 1.23 & 3.88 & 1.36 & 3.81 & 1.40\end{array}$ responsible for your protected area to respond to your requests?
1) More than 24 months
2) 13-24 months
3) 7-12 months
4) 3-6 months
5) Less than 3 months

\section{Shared Actions or Commitments}

12. When you collaborate with other sectors, does $20 \%$ 3.09 1.15 the cost for managing the protected area become less?

1) Strongly disagree 

2) Disagree
3) Neutral
4) Agree
5) Strongly agree

13. Has the State policy recognized rights of local $20 \%$ people to benefit from the protection of your protected area?
1) Strongly disagree
2) Disagree
3) Neutral
4) Agree
5) Strongly agree

14. Has the State policy recognized the historical values and customs of indigenous people on harvesting and using natural resources?
1) Strongly disagree
2) Disagree
3) Neutral
4) Agree
5) Strongly agree

15. Is there a lack of incentive policies (such as contracts, credits, loans for revenuegenerating investments...) to motivate local people to collaborate with you?
1) Strongly agree
2) Agree
3) Neutral
4) Disagree
5) Strongly disagree

16. What tasks are local people involved in the management? (Please write the content of the collaborations between the management board and local people

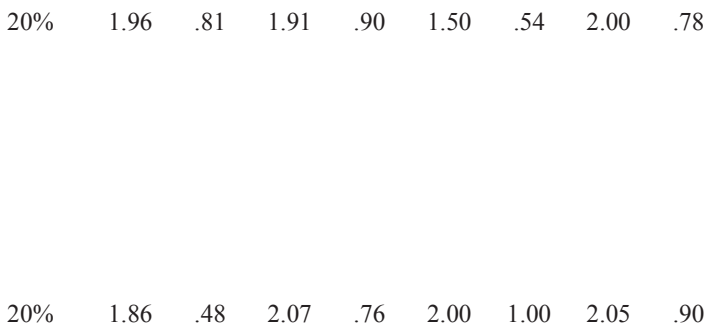

Scoring system: Scores judged from 1 to 5 are based on the essence of tasks in which local people can be engaged. One point is for engagements in only tasks relating labor works such as forest patrol, plantation, forest fire precaution and fighting. Two points are for involvements in information dissemination projects such as awareness raising, environmental education. Three points are for engagements in conservation and livelihood development projects such as biodiversity investigation, ecotourism, information exchange, and NTFP harvesting. Four points are for engagements in consultancy works such as construction of village's forest protection regulations and consultancy. Five points are for involvements in policy formulation tasks. 


\section{SUMMARY}

To protect its natural heritage and biodiversity, Vietnam has established a system of 'special use forest' (SUFs) which is "the backbone of the national protected areas". Today, Vietnam has a total of 164 SUFs covering 2.2 million hectares, equivalent to $7.4 \%$ of the country's total land area and $4.9 \%$ of national territorial waters. Despite a huge increase of SUFs over the last 25 years biodiversity and forest density in Vietnam continues to decline. This is because of the ineffective management of SUFs based solely on the state, which is compounded by a combination of poor surveillance and weak active engagement with local communities surrounding SUFs who are dependent on forest resources for their livelihoods. Conflicts have commonly ensued between local users and authorities responsible for nature conservation when the former have been forcefully excluded from protected areas, following a rigid set of SUF policies and law enforcement. Like many other developing countries, prohibiting natural resource use in protected areas provides no incentive for responsible and sustainable use; rather, local residents maximize resource exploitation as opportunities arise. For decades, SUFs have faced a diverse set of social challenges and become contested space for groups of people with different interests, culture, overlapping land use rights and power.

Recognizing this, the Vietnamese government and international conservation organizations alike, have sought to develop what is referred to as collaborative or 'co'-management for SUFs. At its core co-management captures the idea that rights and responsibilities in natural resources management should be shared between government and any non-state actor (including resource users, local communities, environmental NGOs or scientists). It is advocated not only because it holds the potential to enhance the effectiveness of natural resource protection and management, but also because it brings stakeholder participation and therefore fairness, transparency, legitimacy and accountability to management. By allowing joint decision making, co-management takes into account the needs of resource users, and in doing so considers the complexities and uncertainties they face. Comanagement is also thought to improve compliance to jointly defined regulation, provide more locally relevant management plans, and even reduce poverty through diversifying economic activities. If these wider goals can be achieved co-management is thought to also offer a means of conflict resolution and helps reduce costs of resource management such as data collection, monitoring and enforcement, and leads to the empowerment and selfdetermination of local communities.

However, it is widely noted that co-management is a particularly great challenge in Vietnam because of the nature of strong state control, decades of SUF conflicts, and the lack of capacity and initiatives of communities to negotiate with the government. Moreover, the Vietnamese political system is markedly different from western countries, especially when it 
comes to the concept of 'ownership' of nature resources and the essence of democracy, while the implementation of co-management is considered as a democratic, efficient and equitable system of governance. Therefore, this thesis questions the degree to which comanagement can be put in Vietnamese SUFs and the degree of 'adaptiveness' it can engender. Conditions of the economic, political and social context surrounding SUFs becomes key to any understanding of how co-management can be implemented, including insights into how co-management may need to amended to adjusted to 'fit' the context of mono-organisational states. To do this, we are able to move beyond co-management as a normative hope and start to unpack co-management as a set of fragile, contested decisions and partnerships between highly diverse actors. And thus, this thesis explores not one, but two so called 'spectrums' which are firstly focusing on adaptiveness possible under the conditions of mono-organisational states, and secondly on the degree to which non-state involvement is politically feasible in the context of these states. By taking these two theoretically informed spectrums the thesis explores the wider relevance of co-management to centralised state through the following research questions:

1. How the current form of co-management national system of Special Use Forests governance of Vietnam can be characterised?

2. And how and to what extent more adaptive form of SUF co-management to evolve in Vietnam's forest management.

To address these questions a two-level methodology was adopted throughout this thesis. The first level focuses on the national level with the goal of identifying patterns and characteristics of SUF co-management across the country. The second level focuses on contrasting case studies, designed to draw out diverse local contexts and conditions while allowing for comparison. These levels are restricted to separate papers to help cross-check general and specific findings against each other. In both levels of analysis quantitative and qualitative forms of data collection and analysis were employed. To consolidate the quality of the research, additional observations and discussions were also conducted during workshops and conferences.

The first empirical chapter (Chapter 2) raises vital concerns about the legal framework for officially enabling SUF co-management to exist and evolve in the Vietnamese socialpolitical-economic context. Relevant national policies and legal documents are reviewed, within a framework of SUF co-management in Vietnam. This chapter reveals the form of co-management and the extent to which it is supported by the current policy and legal framework in Vietnam, contributing to a wider understanding of how Vietnam includes (which) ideas of co-management in its still predominantly state-organized system of nature protection. Although there is a clear intention for the development of SUF comanagement, it is biased towards what has been labelled by Sen and Nielsen (1996) an 
'instructive model', characterised by only minimal exchange of information between government and users. It illustrates the tension between decentralization and centralization of SUF management. The government may be willing to call for more participation, but it appears reluctant to delegate significant authority to manage natural resources to local communities and organisations. Moreover, the overlapping mandated responsibilities of governmental agencies creates a difference between the rhetoric and reality in biodiversity conservation and environmental protection. The lack of clarity around property rights has undermined attempts by management boards to engage communities in co-management.

Chapter 3 reports empirical data from the cross-national survey of the SUF managers against a spectrum of co-management arrangements developed from the theories. This helps understand what a Vietnamese SUF co-management arrangement looks like and assess to what extent the government has actually shifted the SUF management toward "international practices" of co-management. Practices of (co-) management were investigated in 105 of the 143 SUFs. The results show that the type of co-management varies little between different categories of SUFs. In general, SUF management arrangements appears to be equivalent to a "cooperative" form of co-management as defined by Sen and Nielsen (1996). However, a national 'style' of Vietnamese comanagement could be identified, labeled 'administrative' co-management. First, despite a degree of pluralism being evident, the stakeholders involved are predominantly part of the state system. Second, communication and negotiation is based on instruction rather than transactive decision making. Third, the one-way nature of instruction leads to very little in the way of what could be labelled social learning - meaning also that higher level authorities also do not respond to or adapt policy and legislation in response to management boards. Finally, any form of shared action is hindered by the weak recognition of local people's rights, historical values and indigenous customs, and a lack of incentive-based policies to motivate stakeholders to collaborate with SUFs. In the essence of "administrative comanagement", therefore that final decision-making power on management remains strongly in the hands of the state in general and the provincial government in particular.

Chapter 4 moves to investigate the existing or "Vietnamese way" of SUF co-management through examining actor interactions in vertical and horizontal linkages of the arrangement through the lens of network governance perspectives. A critical institutional perspective is employed to examine the influence of the vertical and horizontal linkages that underline the form and function of SUF co-management. Data is presented from a nation-wide survey of 113 SUFs, 22 randomly in-depth interviews and four in-depth case studies of SUFs. The results show that the success of co-management in centralized states like Vietnam depends on the greater devolution of allocative power from central to district governments to facilitate horizontal networked collaboration with local communities. Yet the results also 
indicate that the central state maintains an important role in setting the conditions that allow for the success of these networked collaborations. These findings reflect on the need further development of a critical institutional approach for understanding the purpose, interests and resources of co-management in the context of centralized states.

Chapter 5 then discusses the challenges faced by NGOs to fulfil the role of "bridging organisations" within the SUF governance system. We analyse how and to what extent these NGOs fulfil bridging roles in context of administrative co-management by using four key capabilities: knowledge sharing, common vision, conflict resolution and local empowerment. Based on a national survey of SUF managers and four in-depth case studies of NGO engagement in SUFs, the results indicate NGOs can only partly fulfill their bridging roles in the dominant mode of Vietnamese administrative co-management. There exists specific modes of information exchange which have been performative rather than transformative due to a lack of mandated space provided by the government. NGOs also play an important role in building a common vision around SUF co-management based on both international and domestic experiences, but they hardly make any changes to SUF policy because of an unwillingness to devolve any decision making control away from the state. Additionally, NGOs can be a neutral arbiter of partnerships between private sectors, scientists, and other NGOs, but further success in this role would require a shift away from the singular focus on state (controlled) networks. And finally, NGOs demonstrate they have an important role in strengthening community empowerment, yet this role is also currently constrained in Vietnam given that this bridging function is often deemed as a political activity by the state and therefore restricted. These altogether show that the structural barriers of state engagement with NGOs need to better contextualise the form and function of bridging organizations in natural resource management.

The last chapter draws out the research findings and figures out how the findings feed into the theoretical perspectives of co-management. The key results of the thesis identify and define administrative co-management in Vietnamese SUFs. The thesis points to the specific challenges of collaborative forms of natural resource management in centralized states. The results also show that while ambitions for collaborative management are derived from what is widely seen as an international imperative or 'best practice', its translation into Vietnam could be considered partial at best. However, the development of adaptive forms of comanagement in the context of centralized 'mono-organisational' states contains possibilities. An 'administrative' co-management is a likely outcome when a combination of three key principles of adaptive co-management are not addressed: pluralism, accountability and incentivisation. These three inter-related principles offer insights into how measures can be taken to ensure that an administrative co-management regime can be made more adaptive to local conditions and therefore more effective in instituting conservation measures in SUFs. Based on the findings of this thesis further investigation should be about 
the ability of vertical networks in mono-organizational states to adapt to local and constantly changing conditions. This raises questions about the relative flexibility and degree of adaptiveness that these states can hope to exhibit. Comparative research on administrative co-management in different 'mono-organisational' states might provide us better insights regarding this issue. 
Nguyen Thi Kim Dung

Wageningen School of Social Sciences (WASS)

Completed Training and Supervision Plan

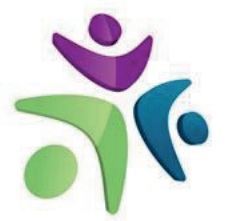

Wageningen School

of Social Sciences

\begin{tabular}{|c|c|c|c|}
\hline Name of the learning activity & Department/Institute & Year & ECTS* \\
\hline \multicolumn{4}{|l|}{ A) Project related competences } \\
\hline $\begin{array}{l}\text { Social Theory and the Environment: An } \\
\text { Introduction into Ecological } \\
\text { Modernisation Theory }\end{array}$ & MG3S/SENSE & 2008 & 6 \\
\hline $\begin{array}{l}\text { FNP-31306 Community-based } \\
\text { Conservation and Rural Development }\end{array}$ & WUR & 2008 & 6 \\
\hline \multicolumn{4}{|l|}{ Theoretical Perspectives } \\
\hline \multicolumn{4}{|l|}{ B) General research related competences } \\
\hline $\begin{array}{l}\text { Mansholt Introduction course } \\
\text { Research Methodology I: From topic to } \\
\text { proposal }\end{array}$ & $\begin{array}{l}\text { MG3S } \\
\text { MG3S }\end{array}$ & $\begin{array}{l}2007 \\
2007\end{array}$ & $\begin{array}{c}1,5 \\
4\end{array}$ \\
\hline $\begin{array}{l}\text { Quantitative Research Methodology } \\
\text { Methods, Techniques and computer tools } \\
\text { for qualitative data collection and analysis }\end{array}$ & $\begin{array}{l}\text { MG3S } \\
\text { MG3S }\end{array}$ & $\begin{array}{l}2007 \\
2008\end{array}$ & $\begin{array}{c}4 \\
2.3\end{array}$ \\
\hline YRM-65000 Observation techniques & WUR & $2009 / 2010$ & 0 \\
\hline YRM-65300 Questionnaire construction & WUR & $2009 / 2010$ & 0 \\
\hline $\begin{array}{l}\text { "Administrative Co-management: The Case of } \\
\text { Special Use Forest Management of Vietnam" }\end{array}$ & $\begin{array}{l}\text { Co-management of } \\
\text { Special Use Forests in } \\
\text { Viet Nam: Practices and } \\
\text { Policy Implications }\end{array}$ & 2013 & 1 \\
\hline \multicolumn{4}{|c|}{ C) Career related competences/personal development } \\
\hline Working with EndNote 9 & WUR Library & 2007 & 0.1 \\
\hline Getting Article Published & ENP Group & $2007 / 2008$ & 0.6 \\
\hline Webmaster ERNASIA website & ENP Group & $2007 / 2008$ & 1 \\
\hline $\begin{array}{l}\text { Interpersonal Communication for } \mathrm{PhD} \\
\text { Students }\end{array}$ & WGS & 2008 & 0.6 \\
\hline $\begin{array}{l}\text { Information Literacy, including } \\
\text { introduction EndNote }\end{array}$ & WGS & 2008 & 0.6 \\
\hline Project and Time Management & WGS & 2009 & 1.5 \\
\hline Total & & & 41.2 \\
\hline
\end{tabular}

*One credit according to ECTS is on average equivalent to 28 hours of study load 


\section{About the author}

Nguyen Kim Dung was born on December 11, 1975 in Binh Phuoc province, Vietnam. She has been a lecturer at the University of Science, Hochiminh City Vietnam since 2002. She got her Bachelor's degree in Biology in 1997. In 2000, she got her Master's degree in Ecology at the same university. During her studies and works she recognized the importance of human factors in ecology and found herself more and more interested in interactions between human and nature. Consequently, in September 2007 she pursued her $\mathrm{PhD}$ studies at Environmental Policy Group, Wageningen University, where she switched her knowledge field towards policy and management.

\section{Funding}

This PhD study and research has been funded by Vietnam Ministry of Education and Training. 